Predicting College Closure:

Improving upon the Federal Financial Responsibility Composite Score with Financial Ratio Analysis and Non-Financial Risk Indicators

A Capstone Presented to

The Faculty of the Curry School of Education

University of Virginia

In Partial Fulfillment

of the Requirements for the Degree

Doctor of Education

by

Steven R. Sherman

A.B., Duke University

M.B.A., University of Virginia

May 2016 


\begin{abstract}
The Department of Education is charged by the Higher Education Act of 1965 with carefully stewarding the federal government's massive investment in higher education. A critical tool toward that effort is the Financial Responsibility Composite Score (FRCS), a metric used to assess the financial health of all higher education institutions and to identify those at risk of closure, but which has been criticized in recent years for its flawed methodology and the resulting high costs of its errors.

The purpose of this research was to add to the body of knowledge on financial assessment in higher education by first evaluating the accuracy of the FRCS, and then determining whether an alternate model could better differentiate between colleges at risk of closure and colleges that are financially stable. A preliminary analysis suggests that the FRCS is largely ineffective in either predicting precipitous closure or identifying colleges that are financially stable. This study proposes an alternate model, the Modified Risk Assessment (MRA) Index, that builds upon evolving research by including in its methodology four financial ratios, eight key risk indicators, and a multi-year weighted average formula. Through extensive financial analysis of 25 private, non-profit colleges, the MRA Index demonstrates a potential improvement in predicting college closures.

Keywords: higher education finance, college closure, ratio analysis, financial responsibility standards
\end{abstract}




\section{For Rachel}

I wish you could have been there for the sun \& the rain $\&$ the long, hard hills. For the sound of a thousand conversations scattered along the road.

For the people laughing \& crying \& remembering at the end.

But, mainly, I wish you could have been there. --Brian Andreas 


\section{Acknowledgements}

This research would not have been possible without the herculean efforts of my committee: Dr. Brian Pusser, Dr. Justin Thompson, and Dr. Catherine Brighton. To say that I owe a vast debt of gratitude to the three of you is an overwhelming understatement and does not begin to convey my appreciation of your time, your wisdom, your patience, and your expert guidance. Thank you.

Many thanks to the faculty and staff of the Curry School of Education for dedicating your lives to inspiring and investing in others. Thanks, too, to my doctoral colleagues who paved the road to the finish line and kept me company on the journey with your intellectual curiosity and your friendship.

I am deeply grateful for having had the opportunity to work with many brilliant and talented colleagues at the University of Virginia. In particular, I offer my genuine and heartfelt thanks to Mr. Gary Nimax, a magnificent supervisor, mentor, champion, and friend. Your leadership and camaraderie have been a great highlight throughout these past many years.

To my beloved family and friends who have sustained me with your kindness and support during this chapter of my life: I am grateful for all that you are and all that you have done for me. To my cherished godchildren and nieces and favorite small humans: thank you for infusing my world with happiness and wonderment. And to Dawkins and Rugby: I can never begin to repay you for the gifts of your loyalty and your patience, and for adding more joy to my life than any person deserves. Thank you all. So much. 


\section{Table of Contents}

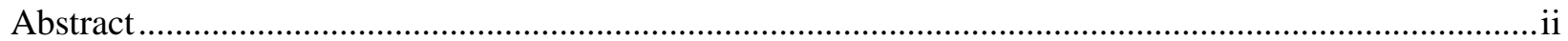

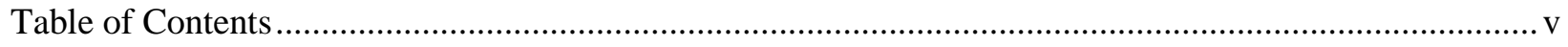

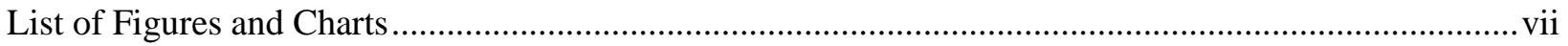

Acronyms and Short Forms Relevant to this Research.........................................................................viii

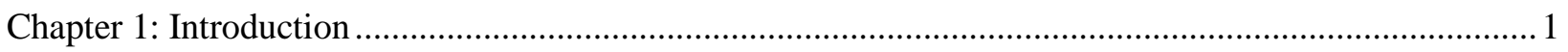

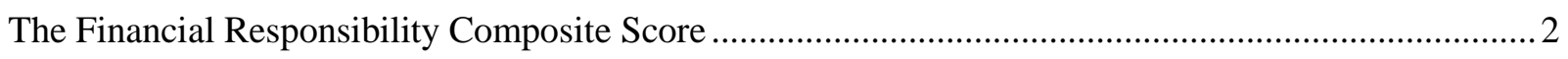

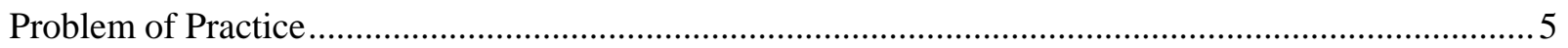

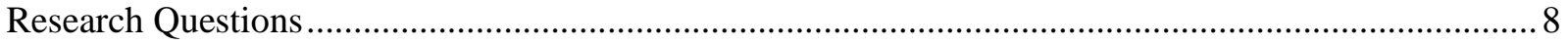

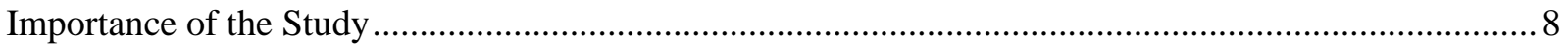

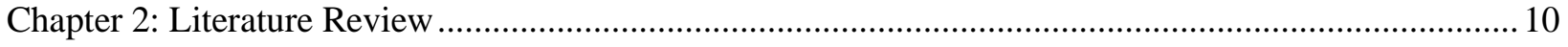

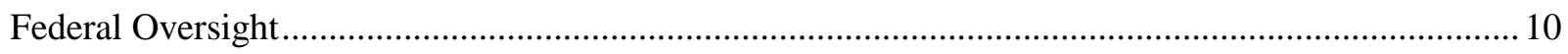

The Modern Financial Context for Private, Non-Profit Colleges ..................................................... 12

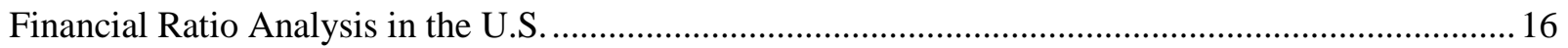

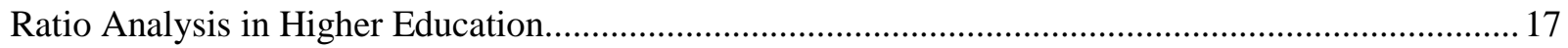

Seminal Works in Higher Education Ratio Analysis ...................................................................20

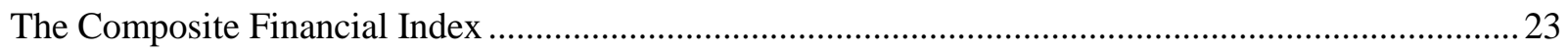

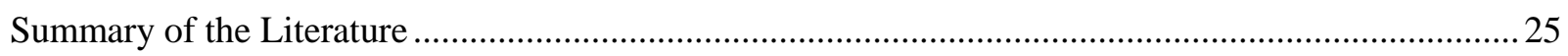

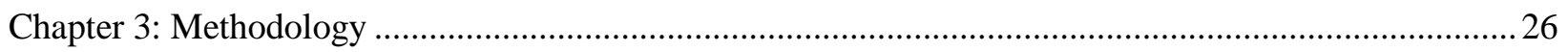

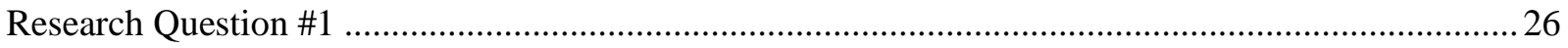

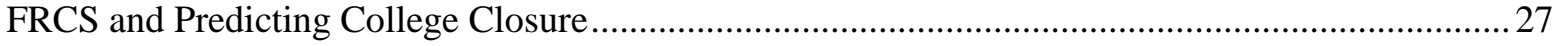

FRCS and Identifying Financially Stable Colleges ..................................................................29

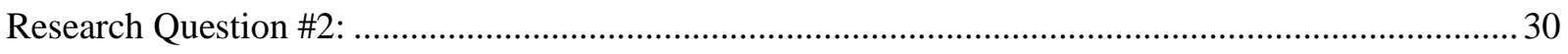

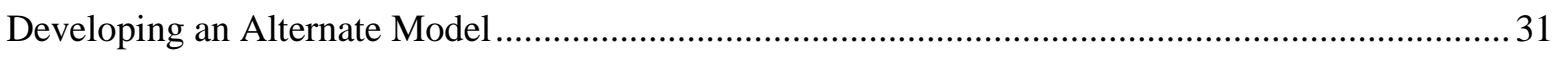

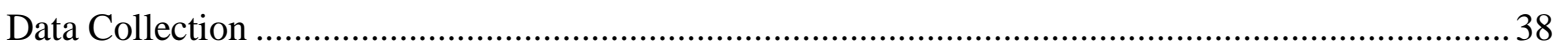

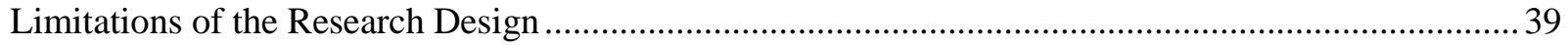

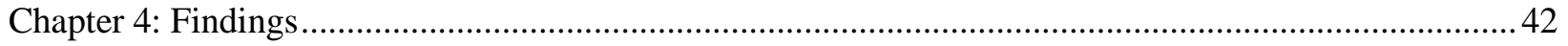

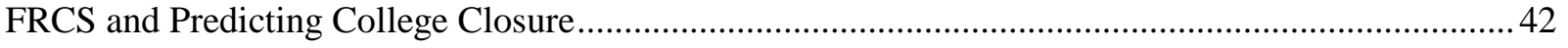

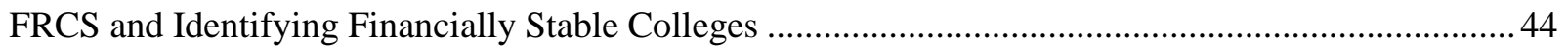

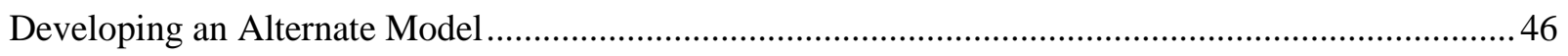

Analysis of Closed Colleges: FRCS versus the MRA Index .......................................................... 48

Analysis of Open Colleges: FRCS versus the MRA Index.............................................................53

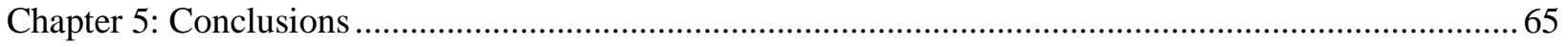

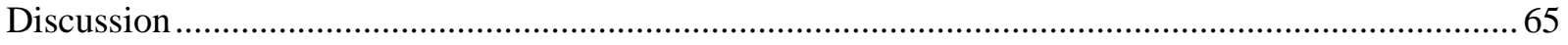

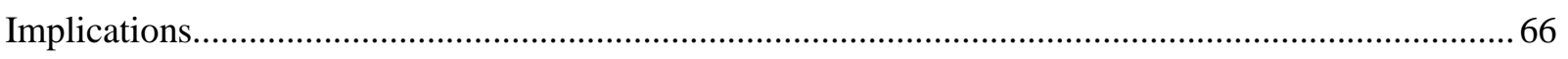

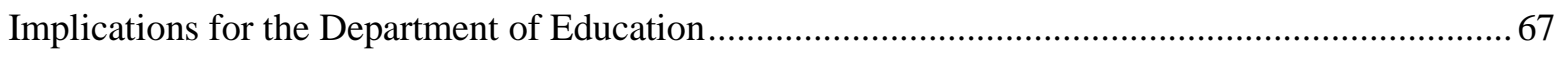

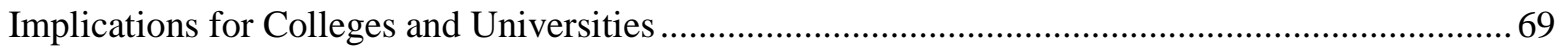




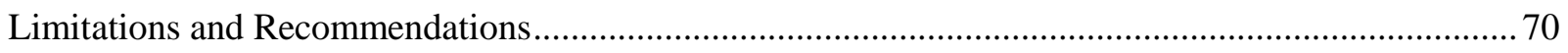

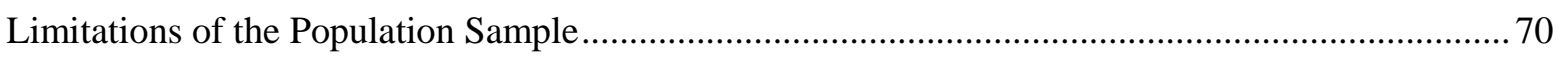

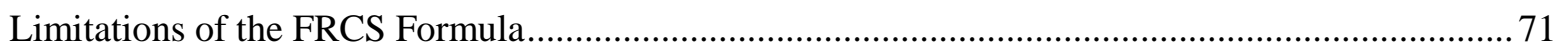

Limitations on Achieving Improvements in Practice..................................................................... 71

Additional Recommendation for Future Research........................................................................... 72

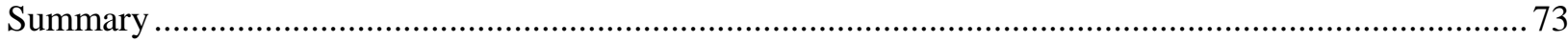

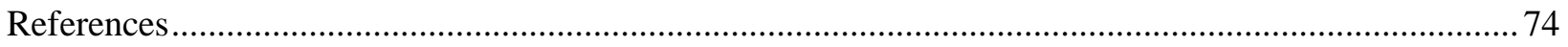

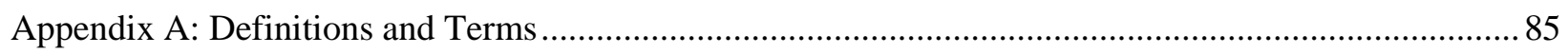

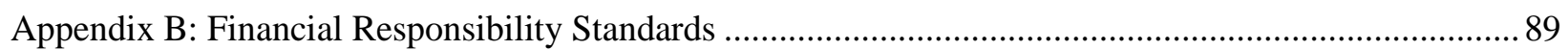

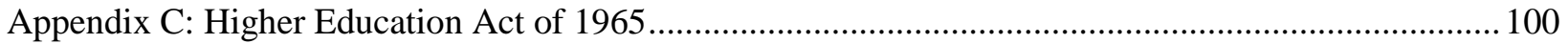

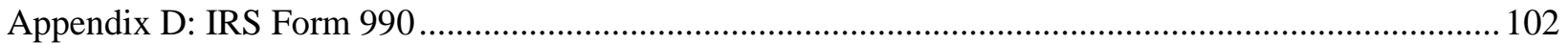

Appendix E: Financial Analysis of 25 Colleges and Universities ...................................................... 114 


\section{List of Figures and Charts}

Figure 1: Financial Responsibility Composite Score Calculations ........................................................ 3

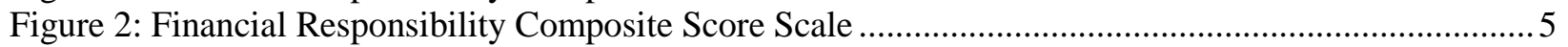

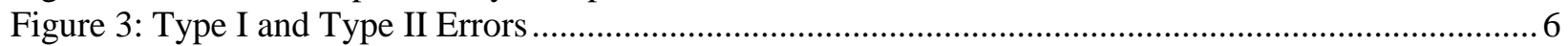

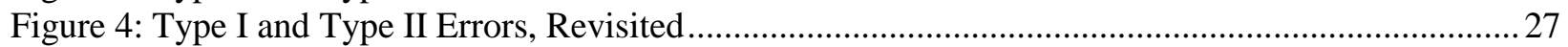

Figure 5: Preliminary Analysis of FRCS Scores for Five Closed Colleges ..........................................28

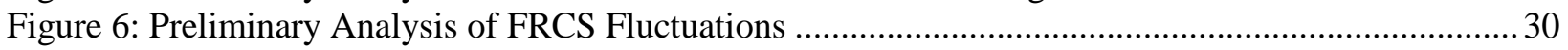

Figure 7: Modified Risk Assessment (MRA) Index Financial Ratio Calculations .................................. 31

Figure 8: Modified Risk Assessment (MRA) Index Risk Indicator Calculations.......................................34

Figure 9: Modified Risk Assessment (MRA) Index Composite Calculations .......................................... 34

Figure 10: MRA Scores for a Sample College with Sensitivity Analysis on Time Calculation Methods.. 36

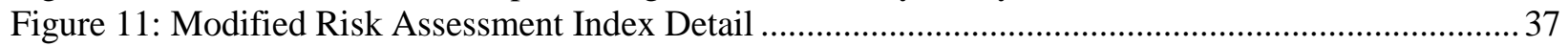

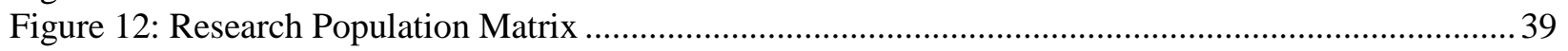

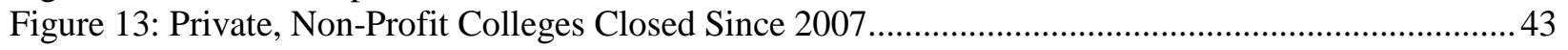

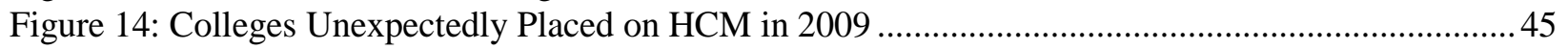

Chart 1: Chester College of New England (Chester, NH) ...................................................................48

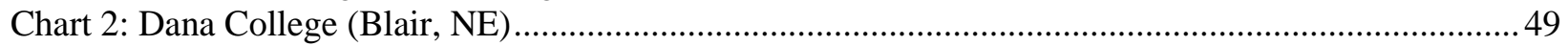

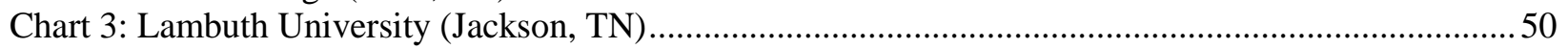

Chart 4: Mid-Continent University (Mayfield, KY) .........................................................................51

Chart 5: Virginia Intermont College (Bristol, VA) ...............................................................................5

Chart 6: Rochester College (Rochester Hills, MI) ..............................................................................5

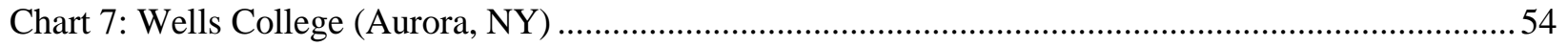

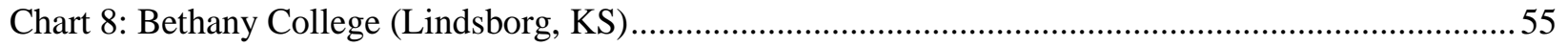

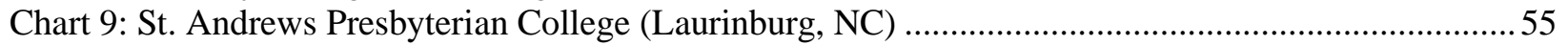

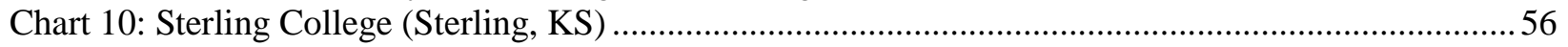

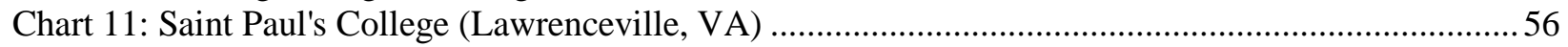

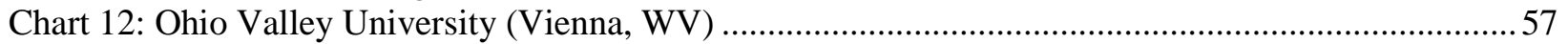

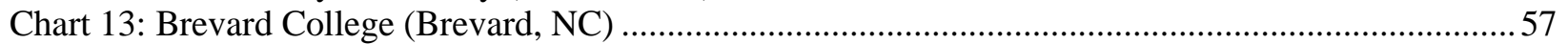

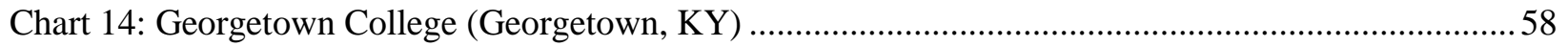

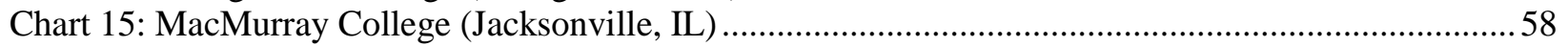

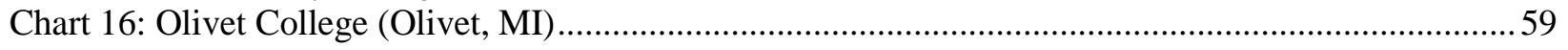

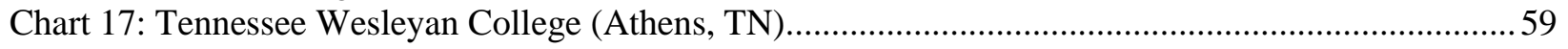

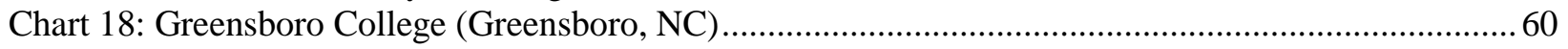

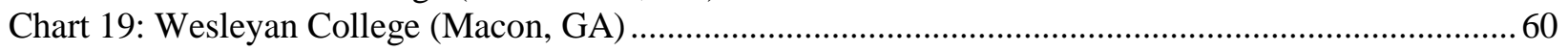

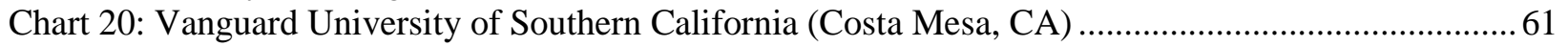

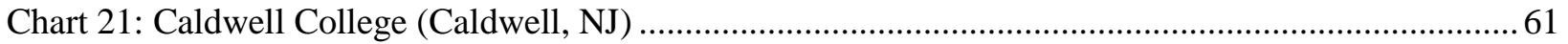

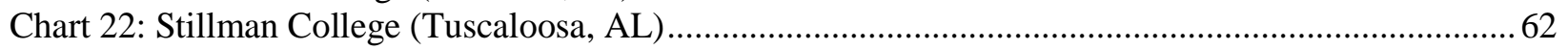

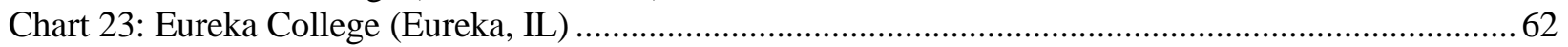

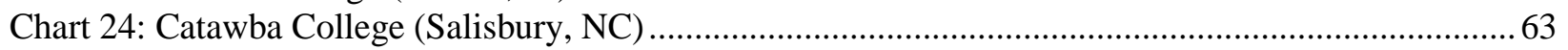

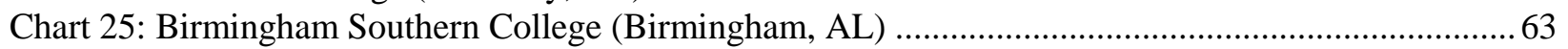




\section{Acronyms and Short Forms Relevant to this Research}

FRCS

MRA

CFI

ED

HEA

$\mathrm{HCM}$

NACUBO

NAICU

Private colleges

For-profit colleges
Financial Responsibility Composite Score

Modified Risk Assessment

Composite Financial Index

U.S. Department of Education

Higher Education Act

Heightened Cash Monitoring

National Association of College and University Business Officers

National Association of Independent Colleges and Universities

Private, non-profit colleges and universities

Proprietary, for-profit colleges and universities 


\section{Chapter 1: Introduction}

The higher education sector currently faces an ever-increasing amount of pressure from economic forces, demographic trends and public opinion. Throughout the past decade, 157 institutions have closed their doors (National Center for Education Statistics, 2015, Table 317.50). Current predictions suggest that the rate of closure will triple in coming years (Moody's Investors Service, 2015), and a recent study suggests that an astonishing one third of colleges are on a financially unsustainable path of spending more than they can afford (Denneen and Dretler, 2012).

The U.S. Department of Education (ED) is charged with carefully stewarding the federal government's enormous investment in higher education. The signature component of that investment - Title IV student aid funding — was legislated by the Higher Education Act of 1965 and expanded by the Middle Income Student Assistance Act of 1978. Today, that federal investment in higher education has grown to over $\$ 150$ billion annually. Partly due to this massive amount of funding and the large number of students and institutions involved, ED has established extensive regulatory oversight over higher education.

The Higher Education Act (HEA) explicitly charges the Secretary of Education with certifying that institutions receiving Title IV funding have "sufficient resources to ensure against the precipitous closure of the institution" (Higher Education Act of 1965, §498(c)). Toward that effort, ED developed a formula in 1996 to assess financial stability and to identify institutions at risk of closure due to financial distress (Hackett \& Carrigan, 1998). Known as the Financial Responsibility Composite Score (FRCS), this formula is a composite index based on three basic financial ratios and serves as a proxy for financial viability. Institutions found to have failed the 
federal Financial Responsibility Standards are placed on Heightened Cash Monitoring (HCM), which subjects them to additional scrutiny and compliance requirements.

\section{The Financial Responsibility Composite Score}

In order to qualify for Title IV funding, all higher education institutions - whether public, private non-profit, or for-profit - must submit annual audited financial statements to the Department of Education. Acknowledging that the considerable differences among these three segments in accounting methods, funding sources and profit incentives have resulted in dissimilar financial statements, ED uses a specific formula for each group. For the population of private, non-profit colleges, the federal Financial Responsibility Composite Score is based on the following three essential financial ratios:

\begin{tabular}{|clc|}
\hline Primary Reserve Ratio & $=\frac{\text { Adjusted equity }}{\text { Total expenses }}$ \\
\hline Equity Ratio & $=\frac{\text { Modified equity }}{\text { Modified expenses }}$ \\
\hline Net Income Ratio & $=$ & Income before taxes \\
\hline
\end{tabular}

The National Association of College and University Business Officers (NACUBO) Advisory Report (1998) provides a guide to understanding these three ratios:

Primary Reserve Ratio. The primary reserve ratio is defined as expendable net assets divided by total expenses. It measures an institution's expendable resources in relation to its overall operating size. According to ED, the primary reserve ratio measures whether an institution has financial resources sufficient to support its mission - that is, whether the institution has (1) sufficient financial reserves to meet current and future operating commitments, and (2) sufficient flexibility in those reserves to meet changes in its programs, educational activities, and spending patterns. Thus, the primary reserve ratio provides a measure of two of the fundamental elements of financial health—financial viability and liquidity. 
Equity Ratio. The equity ratio is defined as modified net assets divided by modified assets. The equity ratio measures the amount of resources that are financed by owners' investments, contributions, or accumulated earnings. According to ED, it measures an institution's capital resources, ability to borrow, and financial viability.

Net Income Ratio (Net Operating Revenues Ratio). The net income ratio measures an institution's profitability or ability to operate within its means for the year. It is defined as change in unrestricted net assets over total unrestricted revenue. According to ED, an institution "must generate surpluses to build reserves for future program initiatives and to increase its margin against adversity." However, recognizing that this surplus is not always possible, the strength factor scores are set so that an institution will get some credit toward the composite score even if it incurs a small loss.

These three definitions are central to a basic understanding of the Financial Responsibility Composite Score index. A full list of definitions widely-used in higher education financial analysis and relevant to this study can be found in Appendix A: Definitions and Terms.

From the detailed financial data provided to the Department of Education by each institution, ED calculates the three ratios as detailed in the following chart:

\section{Figure 1: Financial Responsibility Composite Score Calculations}

$\begin{aligned} & \text { Primary Reserve Ratio } \\ & \text { Adjusted Equity } \\ & \text { Total Expenses }\end{aligned}=\frac{\left(\begin{array}{l}+ \text { Unrestricted Net Assets } \\ + \text { Temporarily-restricted Net Assets } \\ \text { - Land, Buildings, and Equipment (net of accumulated depreciation) } \\ + \text { Long-term Debt } \\ \text { - Temporarily-restricted Annuities, Term Endowments and Life Income Funds } \\ \text { - Intangible Assets } \\ + \text { Post-retirement and Post-employment Obligations }\end{array}\right)}{\left(\begin{array}{c}\text { Total Expenses }\end{array}\right)}$


Equity Ratio

$\begin{aligned} & \text { Modified Equity } \\ & \text { Modified Expenses }\end{aligned}=\frac{\left(\begin{array}{l}+ \text { Net Assets } \\ - \text { Intangible Assets } \\ - \text { Unsecured Related-party Receivables }\end{array}\right)}{\left(\begin{array}{l}+ \text { Total Assets } \\ - \text { Intangible Assets } \\ - \text { Unsecured Related-party Receivables }\end{array}\right)}$

Net Income Ratio

$\frac{\text { Income Before Taxes }}{\text { Total Revenues }}=\frac{(\text { Change in Unrestricted Net Assets })}{(\text { Total Unrestricted Revenue })}$

After computing the three above ratios for each college, the results are scaled on a range of -1.0 to 3.0 , with a score of 1.0 or higher indicating that the institution is financially responsible. As reflected in the following diagram from the Department of Education, colleges with FRCS scores -1.0 to 0.9 have failed the financial responsibility standards and are subject to additional scrutiny. These failing scores correlate to the strictest level of additional regulation, Heightened Cash Monitoring Level 2(HCM2). Colleges with FRCS scores 1.0 to 1.4 are placed in a probationary "Zone", correlating to a lighter level of scrutiny, HCM1. 
Figure 2: Financial Responsibility Composite Score Scale

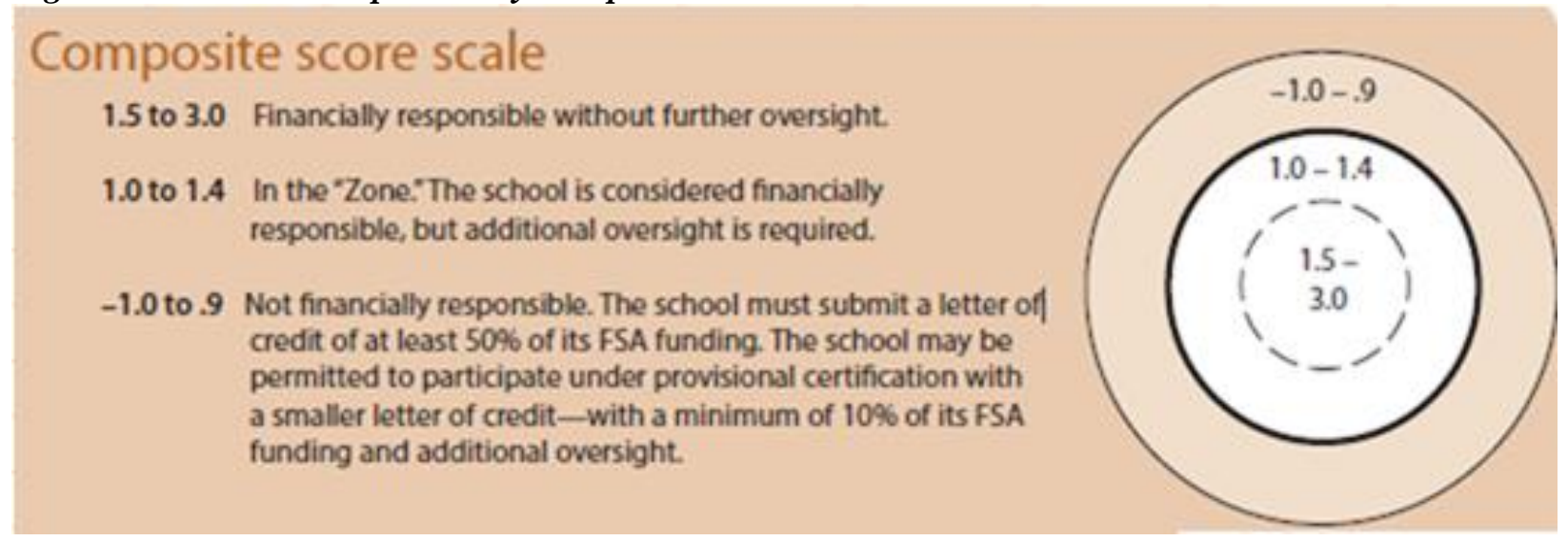

U.S. Department of Education, 2015

A more detailed description of the Financial Responsibility Standards appears in Chapter 11 of the Federal Financial Student Aid Handbook, excerpted below in Appendix B. As of December 1, 2015, 86 institutions were placed on HCM2, and 454 institutions on HCM1 (Postsecondary Education Participants System, 2015).

\section{Problem of Practice}

Though most higher education stakeholders would agree on the importance of a federal system to evaluate the financial viability of colleges and to protect students and taxpayers from the costs of precipitous closure, an inaccurate formula burdens both institutions and the public with significant cost. The federal Financial Responsibility Composite Score (FRCS) methodology has been the target of increased criticism in recent years. In 2010, after 100 financially stable colleges were unexpectedly placed on Heightened Cash Monitoring (HCM), many colleges, higher education advocates and even federal legislators began to express a fervent interest in improving the accuracy and the effectiveness of the methodology (Blumenstyk, 2013; National Association of Independent Colleges and Universities, 2012; Task Force on Federal Regulation of Higher Education, 2015). 
The value of the FRCS metric is confirmed by each institution correctly identified by a failing or passing score. By accurately detecting a college at risk of precipitous closure, the FRCS empowers ED to carefully manage the Title IV funding by manually approving "every dollar that flows to an institution" (Stratford, 2015). By accurately assessing a college in strong financial health, the FRCS allows these institutions to participate in Title IV funding without the encumbrance and costs of additional scrutiny. However, each error in the FRCS — whether Type I "false positives" or Type II "false negatives"—could have weighty consequences, either for institutions or for the public. The following matrix illustrates both the potential successes and failures of the FRCS:

Figure 3: Type I and Type II Errors

\begin{tabular}{|c|c|c|c|}
\hline \multirow{2}{*}{ 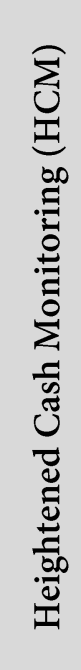 } & $\begin{array}{l}\text { Colleges } \\
\text { placed on } \\
\text { HCM }\end{array}$ & $\begin{array}{l}\text { FRCS accurately identifies colleges at } \\
\text { risk of precipitous closure } \\
\text { (FRCS score }-1.0 \text { to } 0.9 \text { ) } \\
\text { Result: ED closely monitors and } \\
\text { administers Title IV funding }\end{array}$ & $\begin{array}{l}\text { Type I Errors ("false positives"): } \\
\text { FRCS inaccurately awards a failing } \\
\text { score (-1 to 0.9) to financially stable } \\
\text { colleges } \\
\text { Result: stable colleges incur unnecessary } \\
\text { financial and/or reputational costs }\end{array}$ \\
\hline & $\begin{array}{c}\text { Colleges not } \\
\text { placed on } \\
\text { HCM }\end{array}$ & $\begin{array}{l}\text { Type II Errors ("false negatives"): } \\
\text { FRCS inaccurately awards a passing } \\
\text { score ( } 1.0 \text { to } 3.0 \text { ) to colleges at risk of } \\
\text { precipitous closure } \\
\text { Result: students and taxpayers incur } \\
\text { preventable losses }\end{array}$ & $\begin{array}{l}\text { FRCS accurately identifies colleges in } \\
\text { strong financial health } \\
\text { (FRCS score } 1.0 \text { to } 3.0 \text { ) } \\
\text { Result: stable colleges avoid } \\
\text { unnecessary financial and/or } \\
\text { reputational costs }\end{array}$ \\
\hline & & Financially Distressed & Financially Stable \\
\hline & & \multicolumn{2}{|c|}{ Financial Health } \\
\hline
\end{tabular}

As represented in the upper-right quadrant, Type I errors or "false positives" are financially healthy schools that are unfairly subjected to HCM due to imprecision in the FRCS measure. The outcome of Type I errors include expensive financial and non-financial costs to the institution, including the expenses of posting a letter of credit and increased administrative staff 
burden, cash liquidity issues, or reputational damage. In releasing its final regulations in the Federal Register in 1997, ED acknowledged that a "substantial number" of colleges are likely to be burdened by "significant economic impacts" (U.S. Department of Education, 1997, p. 62871). As an example of the immediate financial costs of a Type I error, ED offers a conservative estimate that a small college would spend $\$ 125,000$ or more to post a letter of credit, an unnecessary expenditure at a time when small colleges are struggling to minimize expenses. As evidence of the potential reputational cost, the Department of Education refused for many years to release names of specific colleges placed on HCM. According to an ED official, "given the highly competitive environment in which these institutions conduct business, any public release of the confidential financial standing of these institutions will likely cause the institutions substantial competitive injury" (Stratford, 2015). Ultimately, ED relented to persistent media requests and now publishes quarterly HCM lists (Postsecondary Education Participants System, 2015). While the public certainly has a valid interest in knowing which colleges are subjected to HCM, both the estimated costs and the risk of "substantial competitive injury" underscore the importance of formulating a metric that minimizes the unfair costs of Type I errors.

Conversely, Type II errors or "false negatives" found in the lower-left quadrant above are financially-distressed schools awarded passing FRCS grades. Type II errors represent risk to taxpayers in forfeited federal funding and potential risk to students in diminished value of their educational and financial investment. In the recent example of for-profit Corinthian Colleges, which closed suddenly amid allegations of fraud, the cost of the federal program to forgive the educational loans of tens of thousands of students could cost taxpayers as much as $\$ 350$ billion (Lewin, 2015). Because of the high potential cost of both Type I and Type II errors, it is critical for the FRCS index to be as accurate as possible. 


\section{Research Questions}

The problem of this study concerns the ability of financial assessment tools to correctly differentiate between financially-distressed institutions at risk of closure and those institutions that are financially stable. This research seeks to add to the body of knowledge concerning the use of financial assessment in higher education. Two questions will be addressed:

1. How accurately does the Department of Education's Financial Responsibility Composite Score differentiate between colleges at risk of closure and colleges that are financially stable?

2. Does an alternate model better differentiate between colleges at risk of closure and colleges that are financially stable?

\section{Importance of the Study}

In a time of constrained budgets and downward economic pressure, it is no surprise that the rate of college closures is expected to increase in coming years. Meanwhile, public concerns over tuition increases and abuses in the for-profit education sector have led to an elevated focus on accountability and assessment throughout higher education. Assessment tools such as the federal Financial Responsibility Composite Score are designed to protect public interests in higher education, but also carry a risk of unnecessarily increasing costs to colleges. For that reason, it remains critical that our evaluative models be accurate and effective, committing as few Type I or Type II errors as possible. Based on the increasingly negative response of the higher education community, the errors of the FRCS model no longer meet the standard of acceptability.

Since the FRCS index was introduced in 1996, financial assessment in higher education has grown gradually more sophisticated. Significant improvements in ratio analysis have been 
led by the now widely-utilized Composite Financial Index (CFI) (Tahey, Salluzzo, Prager, Mezzina \& Cowen, 2010), and important research has been done to identify non-financial risk indicators in distressed private colleges (Martin \& Samels, 2009; Lyken-Segosebe \& Shepherd, 2013).

This study aims to provide the Department of Education with an opportunity to benefit from these recent enhancements in practice and steady expansion of knowledge by refining its FRCS formula. Any improvement in the ability of the FRCS to differentiate between financiallydistressed colleges at risk of closure and those that are financially stable could have a critical impact on students, taxpayers, and institutions. As a secondary and potentially valuable outcome, advancements in financial assessment tools would also enable college leaders to enhance their understanding of their own institution's financial health and potentially include new data in their strategic decision-making. 


\section{Chapter 2: Literature Review}

\section{Federal Oversight}

The United States federal government has had a powerful role in higher education throughout history. Through the Morrill Acts of 1862 and 1890 and the G.I. Bill of 1944, and through the billions of dollars in research funding and Title IV financial aid funds, the government has made and continues to make massive investments in American higher education. These investments have fueled extraordinary growth and have made U.S. colleges and universities arguably the most well-respected system in the world (Cole, 2010; Thelin, 2011).

All branches of the government—executive, legislative and judicial—have had farreaching and indelible impacts on the American system of higher education. Most notable among legislated policies is the Higher Education Act (HEA) of 1965, which both increased regulation compliance requirements and established a substantial investment in higher education through Title IV funding. The Higher Education Act of 1965, along with the Elementary and Secondary Education Act, was one cornerstone of President Johnson's Great Society and part of a larger effort to battle poverty, unemployment and crime in the United States. These two acts together represent a momentous leap forward in acknowledging the public purposes fulfilled by all educational institutions. Recognizing that private colleges join public institutions in serving the public good through providing leadership training, a highly-skilled workforce, a democratic citizenry and international understanding, the HEA codified an appreciation that higher education is worthy of significant public investment (Gladieux \& Wolanin, 1976). Today, this investment exceeds over $\$ 150$ billion each year in grants, loans, and work-study (U.S. Department of Education, 2015).

The massive amount of federal funding for student aid, combined with the large number of students and institutions participating in Title IV programs, has led the Department of 
Education (ED) to establish extensive regulatory oversight and conditions that must be met by both students and institutions. In order to qualify for Title IV funding, institutions must submit annual audited financial statements and satisfy financial responsibility standards. HEA explicitly charges the Secretary of Education with certifying that institutions receiving Title IV funding have "sufficient resources to ensure against the precipitous closure of the institution" (Higher Education Act of 1965, $\S 498$ (c)), as seen in the excerpt in Appendix C.

There are currently 7,234 postsecondary institutions that receive Title IV funding (National Center for Education Statistics, 2015), a number that includes two- and four-year public, private non-profit, and proprietary institutions. For ED to adequately monitor the financial condition of that population requires reliable and objective data analysis. Hacket and Carrigan (1998) outline the two main purposes for data analysis: to inform and support institutional decision-making, and to assess an institution's ability to meet its goals. While internal constituents utilize both purposes, external constituents such as accreditors and the Department of Education rely on the latter. As the authors acknowledge, "institutions of postsecondary education should be held accountable to their constituents, their service area, and the public that provides monetary and other support." (p. 2). In 1996, with tuition prices increasing and public sentiment tilting toward increased accountability for colleges and universities, ED created a formula of performance indicators to assess financial stability and performance.

As is tradition in American politics, any effort by the federal government toward increased assessment precipitates an upsurge of advocacy and lobbying on behalf of the stakeholders involved. Mettler (2014) chronicles in unflattering detail the efforts of higher education associations to protect the institutions they represent. Though their objectives 
generally overlap with student interests, these organizations are principally interested in the sustainability of their member colleges and so occasionally work to block reform efforts. As one unfavorable review of higher education associations wryly stated, "Welcome to One Dupont Circle, where good education-reform ideas go to die" (Adler, 2007). Mettler goes on to point out that the advocacy efforts of associations that represent public and private colleges and universities pale in comparison to the tenaciously self-serving lobbying efforts by the banking industry and for-profit institutions. "Like the student lenders, the for-profits possess resources to invest in politics precisely because existing federal student aid policies have already provided them with significant business opportunities. They, in turn, have channeled a portion of those funds back into the political system, seeking the influence to protect and expand the policies that have enabled them to flourish. The public at large, meanwhile, is largely unaware of the issues at stake, remains unorganized around them, and therefore lacks the opportunity to be part of the debate." (pp. 100-101) Throughout recent decades, the federal government has continued its attempts toward education assessment and accountability, but lobbying activities clearly continue to influence the ultimate effectiveness of those reform efforts.

\section{The Modern Financial Context for Private, Non-Profit Colleges}

Private, non-profit colleges are an indispensable component of the higher education landscape in the United States. In addition to the significance of providing diversity of choice in the model of higher education, private colleges succeed in one of the most important output metrics: graduation rates. According to Thelin, Sanoff, Suggs and Wilcox (2006), in the 20 years from 1981 through 2001, private colleges conferred 37\% of all bachelor's degrees in the United States, despite enrolling only $21 \%$ of all students. Demographic groups most at risk of withdrawing — students who work full time or who struggle with learning difficulties or hail from 
underrepresented minority groups — are more likely to graduate from private colleges in four years than they are in six years at a public institution (National Association of Independent Colleges and Universities, 2007). A major contributor toward that success is the lower studentto-faculty ratio that private colleges typically offer, which promotes student academic success (Thelin et al., 2006). At a time when the public spotlight is focused on college completion and time-to-degree, the higher education community should recognize the sector most successful toward those efforts.

Due to a confluence of tuition-dependence, softening demand, and inefficient cost structures, private colleges are particularly susceptible to financial stress (McPherson \& Schapiro, 1999; Van Der Werf, 2002). For these reasons, researchers have long predicted the demise of the private college. William Rainey Harper (1900) first forecast that the financial model of private colleges was unsustainable, and similar concerns were echoed throughout ensuing decades by the American Association of Colleges in 1930, the President's Commission on Higher Education in 1947, the Ford Foundation in 1959 (Benezet, 1976), and the National Council of Independent Colleges and Universities in 1974 (Association of American Colleges, 1974). Although these early predictions may have been premature, recent decades have experienced an increase in college closures as projected. In 1987, the Carnegie Foundation labeled 540 institutions as liberal arts colleges (Breneman, 1994), and by 1999, fewer than 50 were considered financially healthy (McPherson \& Schapiro, 2002). Throughout the past decade, an average of 6.6 private colleges have closed their doors each year (National Center for Education Statistics, 2015, Table 317.50), and current predictions suggest that that rate of closure will triple in coming years (Moody's Investors Service, 2015). Downward economic pressures on 
private colleges appear to be more formidable than ever before, as evidenced by an increased rate of closure in recent decades and future projections.

Much research has been devoted to identifying the most significant risk factors for small, private colleges, though without consensus. Townsley (2002) pointed to high volatility of enrollment, low growth rates, vulnerability to changes in student preferences, and escalating tuition. Christensen and Eyring (2011) applied their theory of disruption to higher education and conclude that the financial crisis at many colleges is caused in part by seemingly-intractable practices in faculty self-governance, departmentalization, the academic calendar, and curricula. Other researchers blamed the labor-intensive model of small colleges (Thelin et al., 2006), student demand for state-of-the-art facilities and technology (Newman, Couturier \& Scurry, 2004; Sora, 2001), financial markets and government regulations (Newman et al., 2004), or tuition discounting practices (Breneman, 2002; Breneman, Doti \& Lapovsky, 2002).

Martin and Samels (2009) present a seminal framework of twenty risk indicators of stressed private colleges. As the authors point out, "a fragile college or university may not demonstrate all twenty, nor does the presence of three or four guarantee vulnerability. However, a preponderance of these twenty indicators clearly means that an institution has slipped, possibly far, from its founding vision and strength, and that some form of surgery will most likely be required to bring it back to health." (p. 9). The following list summarizes their twenty indicators.

1. Tuition discounting more than 35 percent

2. Tuition dependency more than 85 percent

3. Student default rate above 5 percent

4. Debt service is more than 10 percent of the annual operating budget

5. Less than a one-to-three ratio between the endowment and operating budget

6. Average tuition increase greater than 8 percent for five years

7. Deferred maintenance at least 40 percent unfunded 
8. Short-term bridge financing required in the final quarter of each fiscal year

9. Less than 10 percent of operating budget dedicated to technology

10. Average annual alumni gift is less than $\$ 75$, and fewer than 20 percent of alumni give annually

11. Institutional enrollment of one thousand students or fewer

12. Conversion yield is 20 percent behind that of primary competitors

13. Student retention is 10 percent behind that of primary competitors

14. The institution is on probation, warning, or financial watch with a regional accreditor or a specialty degree licensor

15. The majority of faculty do not hold terminal degrees

16. Average age of full-time faculty is fifty-eight or higher

17. The leadership team averages more than twelve years or fewer than three years of service at the institution

18. No complete online program has been developed

19. No new degree or certificate program has been developed for at least two years

20. Academic governance and curriculum development systems require more than one year to approve a new degree program.

In 2013, Lyken-Segosebe and Shepherd tested these 20 risk indicators using data from a population of small, private colleges in Tennessee and found that ten were statistically significant in predicting college closure:

1. Small enrollment

2. Religious and non-degree granting

3. Reliance on part-time enrollees

4. Rapid expansion of graduate and certificate programs

5. High tuition discounting

6. High tuition dependency

7. Large interest expenses

8. Large capital expenses

9. Operating deficit

10. Weak fundraising 
The combination of the work by Martin and Samels with the research by Lyken-Segosebe and Shepherd represents an important advance in the analysis of non-financial risk indicators for small, private non-profit colleges.

\section{Financial Ratio Analysis in the U.S.}

The history of ratio analysis can be traced to the rise of American industrialization in the late $19^{\text {th }}$ century, and important contributions were made by early researchers in their attempt to identify financial ratios that most clearly reflected the financial condition of an organization (Wall, 1919; Bliss, 1923; Thomas, 1955). From this early period evolved an ever-strengthening confidence in the value of the current ratio (Horrigan, 1968), which indicates an ability to pay current debts without eroding cash reserves. The current ratio remains an essential component of ratio analysis today.

Managerial use of ratio analysis began to formalize in the 1950s as the DuPont Company created a ratio triangle to evaluate its operations. The three key ratios in the DuPont Trianglereturn on investment, profit margin ratio, and capital turnover ratio-each continue to serve an important role in modern ratio analysis. Even more significant to the evolution of financial ratio

analysis is the contribution of a framework within which ratios can be analyzed in relationship to one another (Thomas, 1955). This new understanding provided the foundation for composite ratio indices.

In 1968, Edward Altman pioneered a field of research attempting to predict bankruptcy by using a composite of financial ratios. Altman performed a multiple discriminant analysis on manufacturing firms' financial statements. As a result of his analysis, he found five specific ratios that were highly correlated with 95 percent reliability to firms declaring bankruptcy within one year, and 72 percent reliability within two years, even when applied to financial statements 
that appeared to reflect no financial distress at the time. The product of the overall index became known as "the Altman Z-Score".

$$
\begin{aligned}
& \mathrm{Z}=.012 \mathrm{X}_{1}+.14 \mathrm{X}_{2}+.033 \mathrm{X}_{3}+.006 \mathrm{X}_{4}+.999 \mathrm{X}_{5} \\
& \mathrm{X}_{1}=\text { Working capital } / \text { Total assets } \\
& \mathrm{X}_{2}=\text { Retained earnings } / \text { Total assets } \\
& \mathrm{X}_{3}=\text { Earnings before interest and taxes } / \text { Total assets } \\
& \mathrm{X}_{4}=\text { Market value equity } / \text { Book value of total debt } \\
& \mathrm{X}_{5}=\text { Sales } / \text { Total assets } \\
& \mathrm{Z}=\text { Overall Index }
\end{aligned}
$$

(Altman, 1968)

In the decades since Altman developed his Z-score (1968) and adjusted ZETA Score (1977) to accurately predict bankruptcy and analyze credit risk in manufacturing firms, myriad studies have attempted to adapt the formula to evaluate other sectors. Researchers have evaluated industries as disparate as healthcare, restaurant operations, and commercial banking, and other studies have applied the Z-score and ZETA Score to evaluate other market mechanisms and actions such as mergers and acquisitions, initial public offerings, and market reactions to bankruptcy (Berger, Ofek \& Swary, 1996; Carcello, Hermanson \& Huss, 1995; Chen \& Church, 1996; Chen \& Wei, 1993; Gu, 2002).

\section{Ratio Analysis in Higher Education}

As the tools of ratio analysis grew to become more pervasive and more sophisticated in for-profit businesses, the higher education community began to consider its applicability to public and private non-profit colleges. Throughout the literature, the strongest proponents of incorporating ratio analysis in higher education predicted that the practice would achieve several goals: to improve institutional effectiveness, increase accountability, and improve resource allocation decisions (Brand, 1993; Jackson \& Hammonds, 1997; Lewis \& Wasescha, 1987; Murphy \& Eddy, 1998). The first directive arose from the National Commission on the Financing of Postsecondary Education (1973), insisting that "national standard indicators should 
be developed to determine the relative financial status of the different types of postsecondary educational institutions" (p. 225). Partly as a result, throughout the 1970s and 1980s, a great number of researchers conducted a wide range of analysis on higher education financial statements and produced over 300 possible ratios (Brubaker, 1979; Dickmeyer, 1983; Lupton, Augenblick \& Heyison, 1976). This explosion of ratios reflected several challenges of applying ratio analysis to higher education, including the wide diversity in different models of higher education institutions and the lack of generally accepted accounting standards.

During this time when "the art of analyzing the balance sheet of colleges is in its infancy" (Minter \& Bowen, 1976, p.66), several studies began to make significant progress toward identifying meaningful ratio analyses, albeit from different perspectives. Minter and Bowen (1976) applied a subjective analysis to trend lines in revenues and expenditures, and results focused on resources per student. Dickmeyer and Hughes (1980) used median values of financial components to make statistical comparisons between institutions, and defined institutional risk by the vulnerability of a college to changes in its environment. Bolda and Mack (1983) calculated ratios between expenditures and various revenue categories and identified two important factors: student enrollment and number of living alumni. Clearly, while all of these important studies contained thoughtful approaches to improve the assessment of financial health of colleges and universities, the lack of consensus among them belied any claims of serving as an accurate and comprehensive tool for higher education.

Improving upon the vast and disparate array of possible ratios, a noteworthy study on financial assessment was commissioned by the National Science Foundation and the American Council on Education (Gomberg \& Atelsek, 1981). This research analyzed five years of financial 
and non-financial data and resulted in development of a composite assessment of the following eleven ratios:

\section{$\underline{\text { Financial Resources }}$}

1. Current fund ratio

2. Ratio of available fund balances to operating expenses

\section{Estimated Risk}

1. Liabilities-to-revenues ratio

2. Fixed proportion of the budget

3. Ratio of applications to new enrollments

4. Ratio of new enrollment to FTE enrollment

Changes Affecting Financial Resources

1. Ratio of receivables to revenues

2. Dormitory occupancy rate

3. Ratio of salaries to expenditures

\section{Changes in Nonfinancial Resources}

1. Continuing education enrollment

2. FTE Faculty

The results of this study were complicated by the difficulties in analyzing a database containing institutions of varying sizes, control (publics versus privates) and missions (four-year versus two-year). Nevertheless, the recommendations did indicate the efficacy of ratio analysis as a management tool in assessing financial health of higher education institutions.

Entering the 1990s, financial ratio analysis was generally constrained to internal financial analysis; any comparison between institutions was made difficult and ambiguous by the wide range of accounting methods disseminated throughout public and private non-profit organizations (Chabotar, 1989). The 1990s presented several noteworthy events that began to formalize the use of ratio analysis in higher education. In a climate of public pressure to restructure and reform higher education, Generally Accepted Accounting Principles (GAAP) 
evolved in 1995 to provide structure and guidance to non-profit accounting methods. With GAAP standards in place, meaningful comparisons between institutions could be drawn, and the use of financial ratios as an evaluative tool in higher education began to be adopted by the Department of Education (Kieso, Weygandt \& Warfield, 2008).

Beyond the walls of colleges and universities, external stakeholders such as credit rating agencies and lenders also utilize financial ratio analysis to measure relative credit strength and risk. Colleges and universities issue billions of dollars of debt on capital markets. Credit ratings inform a potential investor of the risk of an institution defaulting on its debt payments in the future. Debt issued by a college with a strong credit rating (such as Aaa, the highest rating awarded by Moody's) carries a very low risk of default and is therefore a more secure investment than debt from a college at risk of financial distress. As a result, a financially stable college benefits from a reduced cost of debt expense as well as a greater debt capacity (Moody's Investors Service, 2015).

\section{Seminal Works in Higher Education Ratio Analysis}

Kent Chabotar played a critical role in transferring applicable financial metrics from forprofit businesses to non-profit organizations including colleges and universities. In studying similarities and differences between the two worlds, he recognized that even though for-profits and non-profits have different financial objectives - namely maximizing shareholder value in the former, and supporting mission-driven services for the latter-all organizations share a common need to monitor long-term financial stability, minimize debt and deficits, and maintain accountability and stewardship. Throughout his research (1989, 2006, 2010), Chabotar identified several reliable ratios from corporate finance that would provide an early warning system for 
financial stress in at-risk colleges and would focus institutional leaders on measurable outcomes.

His research focused on ratios in three areas: liquidity, debt capacity, and net operating results.

Liquidity

$$
\text { 1. Current Ratio }=\frac{\text { Unrestricted current assets }}{\text { Unrestricted current liabilities }}
$$

The current ratio focuses on liquid assets, with a target of 1.0-2.0 representing an adequate balance of spendable reserves to spending needs. Ratios below 1.0 could indicate excessive vulnerability to unexpected fluctuations in revenue streams, such as the 2008-2009 economic downturn that brought a severe correction in investment income and philanthropic giving, and left many colleges unable to fund current expenses. On the other hand, ratios above 2.0 could indicate an overly cautious use of cash reserves that could otherwise be employed to support an institution's mission.

$$
\text { 2. } \text { Quick Ratio }=\frac{\text { (Unrestricted current assets }- \text { Inventories })}{\text { Unrestricted current liabilities }}
$$

The quick ratio also focuses on liquid assets. The target of 1.0 represents an adequate balance of cash reserves to spending needs.

$$
\text { 3. Available Funds Ratio }=\frac{(\text { Cash }+ \text { Short-term investments })}{\text { Unrestricted current liabilities }}
$$

The available funds ratio is a more conservative ratio that indicates an institution's true cash position, with a target of $0.75-1.00$. 


\section{Debt Capacity}

$$
\text { 1. Debt-Equity Ratio } \quad=\frac{\text { Plant debt }}{\text { Net investment in plant }}
$$

The debt-to-equity ratio measures the level of debt against fixed assets and tests an institution's capacity to add more long-term debt financing. Chabotar found an appropriate target for nonprofits to be $0.33-1.00$.

$$
\text { 2. Debt Service Ratio }=\frac{\text { Debt service }}{\text { Total operating revenue }}
$$

The debt service ratio measures the relationship of debt payments to revenues. A target of 0.2 represents a sufficient ability to pay debts without compromising future efforts to support mission activities.

Net Operating Results

$$
\text { 1. Net Operating Results Ratio }=\frac{\text { Net total revenue }}{\text { Total revenue }}
$$

The net operating results ratio (also referred to as the net income ratio) indicates the ability of a non-profit organization to consistently generate financial resources to provide ongoing support of an institution's mission, revealing an operating surplus or deficit.

In his 1989 seminal article, Chabotar cautioned against relying too heavily on ratio analysis in making comparisons between institutions. However, it should be noted that at the time, non-profit organizations still lacked standardized accounting practices. While there remain some variations due to different interpretations of standards, the application of GAAP standards by the Financial Accounting Standards Board (FASB) in 1993 and 1995 has greatly improved the relevance of interinstitutional comparisons of financial data. 


\section{The Composite Financial Index}

From 1980 through 2010, seven editions of Strategic Financial Analysis for Higher Education (née Ratio Analysis in Higher Education) have enabled an increasingly-nuanced understanding of institutions' financial health (Tahey et al., 2010). Published by a collaboration

of three firms in the higher education community_KPMG, Prager Sealy, and Attain — this framework has gradually evolved to become the most widely-used model of higher education financial analysis. Each edition has served to incorporate important changes in the higher education financial landscape: the expanding body of knowledge led by the academic research of Chabotar and others; the application of GAAP standards in 1993 and 1995 which enabled meaningful interinstitutional comparisons; an increasing practical use of ratio analysis in strategic decision-making by institutional boards and leadership; and dramatic events in the economic markets that exposed idiosyncratic weaknesses in existing frameworks.

The $7^{\text {th }}$ edition contains the Composite Financial Index (CFI), a blending of four key ratios that together provide information on an institution's financial condition. CFI ratios are weighted and scaled on a range of -4 through 10 . As compared to the narrower FRCS range of -1 to 3, this wider CFI range is designed to offer more sophisticated insight to college leadership to support strategic decision-making. CFI recommendations at various overlapping stages include examples such as the following:

- (-3.0 to 0.0$)$ : With likely large liquidity and debt compliance issues, consider structured programs to conserve cash

- (-1.0 to 2.0): Consider substantive programmatic adjustments

- (2.5 to 5.0): Direct institutional resources to allow transformation

- (6.5 to 9.0): Allow experimentation with new initiatives (Tahey et al., 2010) 
The FRCS, which is designed to simply identify only those colleges that fail the federal financial standards, clearly offers no such assistance in supporting institutional decision-making.

The CFI works toward this noble goal by employing four key ratios to help an institution answer four critical questions about its financial health. Each ratio is designed to address particular areas of concern:

1. Primary Reserve Ratio: are resources sufficient and flexible enough to support the mission?

2. Viability Ratio: are debt resources managed strategically to advance the mission?

3. Return on Net Assets Ratio: does asset performance/management support the strategic direction?

4. Net Operating Revenues Ratio: do operating results indicate the institution is living within available resources? (Tahey et al., 2010)

Each of the four ratios is chosen specifically to work in concert with another. The (1) primary reserve ratio and (2) viability ratio are intentionally linked, with the primary reserve ratio measuring an institution's ongoing operating commitments, and the viability ratio measuring its expendable wealth. Similarly, the (3) return on net assets ratio and (4) net operating revenues ratio are also connected, with the return on net assets ratio measuring an institution's ability to generate a return on assets, and the net operating revenues ratio measuring its ability to live within its means (Tahey et al., 2010). Used together, these two pairs of ratios build a balanced picture of financial health, enabling an institution to see more clearly the financial threats and strategic opportunities that the CFI reveals. 


\section{Summary of the Literature}

Modern financial assessment in higher education is supported by a century of research. Since the dawn of the industrial age, practitioners and scholars have worked steadily to understand the insight that financial statements can provide about financial health. Altman's ZScore (1968) represented a significant contribution in developing a metric that successfully predicts bankruptcy, including companies that had appeared to be financially stable. Chabotar $(1989,2006,2010)$ analyzed the large number of ratios available in for-profit business and identified those that would be most meaningful in non-profit and higher education organizations. Tahey et al. (2010) presented the Composite Financial Index, a blending of four significant ratios across a multi-year timeframe, capturing decades of advancements in institutional financial practices and accounting standards. These contributions in financial ratio analysis are complemented by research from Martin and Samels (2009) and Lyken-Segosebe and Shepherd (2013) on non-financial risk factors that are correlated with closure of small private colleges. Together, these seminal works provide a strong foundation for research that seeks to improve upon the Financial Responsibility Composite Score. 


\section{Chapter 3: Methodology}

The goal of this research is to investigate the ability of a model of analysis to differentiate between colleges at risk of closure and colleges that are financially stable. The Department of Education (ED) relies on the Financial Responsibility Composite Score (FRCS) to protect students and taxpayers by predicting colleges at risk of closure. In recent years, critics have highlighted the inaccuracy of the federal model, pointing to evidence of unforeseen closings as well as the unnecessary inclusion of financially stable colleges on Heightened Cash Monitoring (HCM). This study is designed to answer two primary research questions:

1. How accurately does the Department of Education's Financial Responsibility Composite Score differentiate between colleges at risk of closure and colleges that are financially stable?

2. Does an alternate model better differentiate between colleges at risk of closure and colleges that are financially stable?

\section{Research Question \#1}

How accurately does the Department of Education's Financial Responsibility Composite Score differentiate between colleges at risk of closure and colleges that are financially stable?

The quantitative data generated in this first part of the study will examine the accuracy of the FRCS in identifying colleges at risk of closure. Systemic errors in the metric represent potentially severe costs to students and taxpayers (Type II errors) or institutions (Type I errors). This study will seek to establish whether the frequency of those errors is within an acceptable range. 
Figure 4: Type I and Type II Errors, Revisited

\begin{tabular}{|c|c|c|c|}
\hline \multirow{2}{*}{ 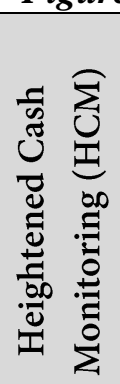 } & $\begin{array}{l}\text { Colleges } \\
\text { placed on } \\
\text { HCM }\end{array}$ & $\begin{array}{l}\text { FRCS accurately identifies colleges at } \\
\text { risk of precipitous closure } \\
\text { (FRCS score }-1.0 \text { to } 0.9 \text { ) }\end{array}$ & $\begin{array}{l}\text { Type I Errors: FRCS inaccurately } \\
\text { awards a failing score (-1 to } 0.9 \text { ) to } \\
\text { financially stable colleges }\end{array}$ \\
\hline & $\begin{array}{l}\text { Colleges not } \\
\text { placed on } \\
\text { HCM }\end{array}$ & $\begin{array}{l}\text { Type II Errors: FRCS inaccurately } \\
\text { awards a passing score (1.o to } 3.0 \text { ) to } \\
\text { colleges at risk of precipitous closure }\end{array}$ & $\begin{array}{l}\text { FRCS accurately identifies colleges in } \\
\text { strong financial health } \\
\text { (FRCS score } 1.0 \text { to } 3.0 \text { ) }\end{array}$ \\
\hline & & Financially Distressed & Financially Stable \\
\hline & & \multicolumn{2}{|c|}{ Financial Health } \\
\hline
\end{tabular}

For the FRCS metric to have accurately identified colleges at risk of precipitous closure, now-defunct colleges that have closed due to financial exigency should have been identified with failing FRCS scores between -1.0 and 0.9 in the two years prior to closure. By extension, those colleges that close after earning a passing FRCS score of 1.0 to 3.0 are examples of Type II errors.

Conversely, the FRCS metric should not award failing scores to financially sustainable colleges, i.e. Type I errors. Though an institution's financial health may change slightly from year to year and distressed colleges might occasionally be able to improve their financial sustainability through strategic planning and shrewd management over time, there should be very few colleges whose FRCS scores fluctuate suddenly between failing and passing. The FRCS formula professes to measure long-term financial viability by virtue of its largest component being a 20x multiplier of the primary reserve ratio; therefore, constant variability could be a sign of an inaccurate metric.

\section{FRCS and Predicting College Closure}

First established by the Altman Z-Score (Altman, 1968), the goal of an analytical model is to predict bankruptcy or closure one to two years prior. Applied to higher education, that two- 
year objective provides a clear practical benefit to the Department of Education: by anticipating closure two years in advance, ED can place a college on the strictest level of HCM in order to carefully manage the disbursement of Title IV funds. Colleges frequently announce their impending closure early in their final academic year to provide students and faculty as much advance notice as possible to plan the course of their future academic careers. A representative example from recent weeks is The Robert B. Miller College announcing in December 2015 that it will close its doors in June 2016. In light of that typical timing and in order for the Department of Education to anticipate as many closures as possible before they occur and to manage the investment of Title IV funds with strict oversight, the FRCS should be able to identify colleges with a failing score (-1.0 to 0.9$)$ in its penultimate year. The sample table below shows a preliminary analysis of five colleges. This study intends to evaluate all private colleges that have closed since 2007 and for whom FRCS scores are available.

Figure 5: Preliminary Analysis of FRCS Scores for Five Closed Colleges

\begin{tabular}{|l|l|r|r|r|}
\hline \multicolumn{1}{c|}{ Institution } & \multirow{2}{*}{ Location } & \multirow{2}{*}{$\begin{array}{c}\text { Year } \\
\text { Closed }\end{array}$} & \multicolumn{2}{c|}{ FRCS Score } \\
\cline { 4 - 5 } & & & penultimate & final year \\
\hline Dana College & Blair, NE & 2010 & 0.6 & 0.6 \\
\hline Chester College of New England & Chester, NH & 2012 & 1.9 & 0.6 \\
\hline Lambuth University & Jackson, TN & 2012 & 0.0 & -0.2 \\
\hline Mid-Continent University & Mayfield, KY & 2014 & 3.0 & 3.0 \\
\hline Virginia Intermont College & Bristol, VA & 2014 & 1.4 & 0.3 \\
\hline
\end{tabular}

Evaluating the ability of the FRCS to predict precipitous closure is relatively straightforward through the lens of hindsight: colleges that have closed due to financial exigency are easily identified. The Department of Education publishes a list of all Title IV recipients that have closed since 1984, and also has made publicly available the list of FRCS scores for all private, non-profit and for-profit colleges during the years 2007 through 2013. A crosscomparison of those two lists will reveal whether the FRCS accurately identified colleges in financial distress before closure. Because each Type II error represents significant costs to both 
students and taxpayers - even if not every closure will match the catastrophic level of Corinthian's $\$ 350$ billion loss-ED should attempt to minimize the number of errors. With this in mind, this study will evaluate the FRCS against a threshold of acceptability of $80 \%$ accuracy.

\section{FRCS and Identifying Financially Stable Colleges}

While colleges that have closed due to financial exigency are definitively identified as "financially distressed" by their closure, the task of identifying "financially stable" colleges is more nuanced. Some colleges persist for many years despite struggling financially. Without the benefit of hindsight, since any of those colleges could announce their closure in coming years, it would be intellectually dishonest to declare all currently-open colleges as financially stable. Nevertheless, the higher education community has an inherent interest in creating a metric that can accurately and reliably identify colleges that present little risk of precipitous closure. In addition to the cost borne by the financially stable institutions that are inaccurately subjected to strict federal oversight, these Type I errors divert the limited resources of ED away from the charge of identifying and overseeing colleges that are truly at risk of closure.

Any college's financial situation will vary slightly from year to year, but the qualities that the Financial Responsibility Composite Score index purports to measure - particularly debt capacity and flexible reserves, which together account for $80 \%$ of the weight of the FRCS - are financial characteristics with a long horizon and therefore should not fluctuate wildly. An assessment of financial health should not be so volatile as to reflect changes in financial strategy as a degradation of financial health. Below is a preliminary analysis of the FRCS scores of five colleges, 2007-2013. 
Figure 6: Preliminary Analysis of FRCS Fluctuations

\begin{tabular}{|c|c|c|c|c|c|c|c|c|}
\hline Institution Name & Location & 2007 & 2008 & 2009 & 2010 & 2011 & 2012 & 2013 \\
\hline Alderson Broaddus University & Philippi, WV & 2.3 & 1.9 & 0.6 & 1.6 & 2.6 & 1.7 & 1.8 \\
\hline Ashland University & Ashland, $\mathrm{OH}$ & 2.7 & 2.3 & 1.3 & 2.3 & 2.9 & 2.7 & 2.8 \\
\hline Bethany Lutheran College & Mankato, MN & 3.0 & 2.2 & 2.2 & 2.7 & 1.4 & 1.5 & 2.9 \\
\hline Bidwell Training Center & Pittsburgh, PA & 2.5 & 2.4 & 2.4 & 0.5 & 2.7 & 2.4 & 3.0 \\
\hline Boise Bible College & Boise, ID & 2.2 & 2.0 & 1.8 & 1.7 & 1.6 & 1.3 & 1.9 \\
\hline
\end{tabular}

While additional exploration is required before definitive conclusions can be made, it is more likely that the aberrant 2010 score of the Bidwell Training Center, for example, is due to a shift in financial strategy or mission rather than a complete and sudden degradation and subsequent restoration of financial stability.

Given that institutions placed on HCM are subject to material financial cost and potential reputational damage, it is in the best interest of the Department of Education and the higher education industry that only institutions truly at risk of closure be placed on HCM. A metric that carelessly commits a great number of Type I errors unduly burdens viable institutions. This preliminary analysis will begin to shed light on the question of how accurate the FRCS is in differentiating between financially-distressed colleges at risk of closure and those that are financially stable.

\section{Research Question \#2:}

Does an alternate model better differentiate between colleges at risk of closure and colleges that are financially stable?

If the FRCS is shown in the first part of this study to perform below the threshold of acceptability in differentiating between colleges at risk of closure and colleges that are financially stable, then the higher education community should continue to seek ever-improving tools of analysis with which to measure financial condition. With vast sets of descriptive 
financial data available, there is great potential for applying updated theory on higher education and finance to improve current practices in higher education financial analysis.

\section{Developing an Alternate Model}

To address the problem of practice, this study will develop an alternate model, the Modified Risk Assessment (MRA) Index, to be applied in an extensive financial analysis of private, non-profit colleges in the years 2004 through 2014. After diligent consideration of the body of literature on financial ratio analysis and non-financial performance metrics, this study proposes to combine the most promising research from several areas.

\section{Financial Ratio Analysis}

The core of the MRA Index will be formed by a blending of three key ratios in the Financial Responsibility Composite Score with a fourth key ratio from the Composite Financial Index.

Figure 7: Modified Risk Assessment (MRA) Index Financial Ratio Calculations

$\begin{aligned} & \text { Primary Reserve Ratio } \\ & \text { Adjusted Equity } \\ & \text { Total Expenses }\end{aligned}=\frac{\left(\begin{array}{l}+ \text { Unrestricted Net Assets } \\ + \text { Temporarily-restricted Net Assets } \\ \text { - Land, Buildings, and Equipment (net of accumulated depreciation) } \\ + \text { Long-term Debt } \\ \text { - Temporarily-restricted Annuities, Term Endowments and Life Income Funds } \\ \text { - Intangible Assets } \\ + \text { Post-retirement and Post-employment Obligations }\end{array}\right)}{\left(\begin{array}{c}\text { Total Expenses }\end{array}\right)}$


Equity Ratio

$\begin{aligned} & \text { Modified Equity } \\ & \text { Modified Expenses }\end{aligned}=\frac{\left(\begin{array}{l}+ \text { Net Assets } \\ - \text { Intangible Assets } \\ - \text { Unsecured Related-party Receivables }\end{array}\right)}{\left(\begin{array}{l}+ \text { Total Assets } \\ - \text { Intangible Assets } \\ - \text { Unsecured Related-party Receivables }\end{array}\right)}$

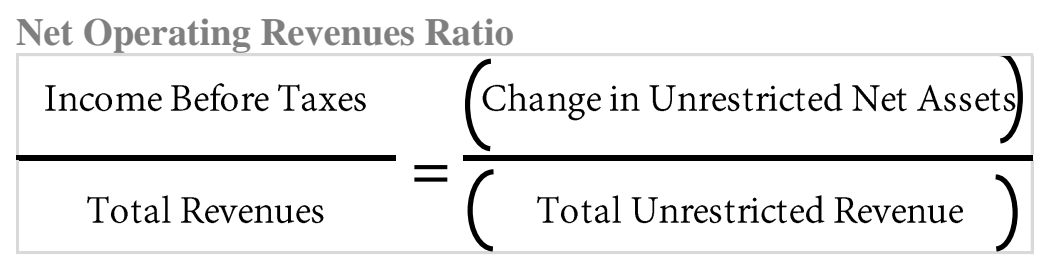

Return on Net Assets Ratio

Financial Asset

Performance

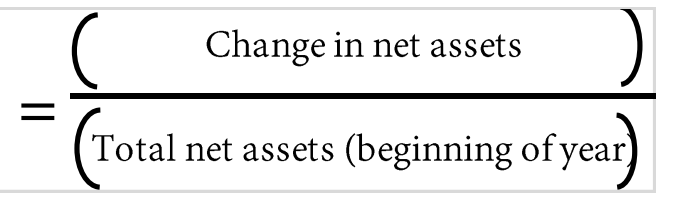

Taken together as two pairs, as the CFI has established, this new set of four ratios will provide a balanced picture of financial health and will provide ratio analysis in the most critical components of financial assessment: long-term financial strength, liquidity, debt structure, and profitability.

\section{Non-financial Risk Indicators}

It is important to note, however, that financial ratio analysis measures only some of the risk factors that might lead to institutional distress; others are represented by the indicators proposed by Martin and Samels (2009) and tested by Lyken-Segosebe and Shepherd (2013). Of the ten risk indicators found to be statistically significant in correlating to college closure, there are eight with data that can be reliably gathered from IPEDS or IRS Forms 990. 
1. Small enrollment: colleges with a small number of students suffer from lack of economies of scale and are especially vulnerable to a decrease in yield. According to Martin and Samels (2009), enrollment of fewer than 2,500 students is correlated to closure; enrollment of fewer than 1,000 creates even greater pressure.

2. Religious affiliation: due to the decreasing size of the demand pool of students, religious institutions are particularly vulnerable.

3. Reliance on part-time enrollees: a ratio of less than 3 full-time undergraduates for every part-time student correlates with colleges in distress.

4. High tuition discounting: colleges that consistently employ a discount rate above $60 \%$ are at increased risk of closure.

5. High tuition dependency: colleges with a reliance over $85 \%$ on a single source of revenue are vulnerable to sudden fluctuations.

6. Large interest expenses: interest payments over $10 \%$ of total budget signify a college that is over-leveraged and has decreased flexibility in future budgeting.

7. Net revenue: negative net income (total expenses greater than total revenue) correlates with risk of closure.

8. Endowment-to-budget: the ratio of the long term pool to operating budget should be at least 3.0.

\section{Modified Risk Assessment formula}

Upon data collection from IPEDS and IRS Forms 990, these eight non-financial risk indicators will be scored as follows: 
Figure 8: Modified Risk Assessment (MRA) Index Risk Indicator Calculations

\begin{tabular}{|c|c|c|}
\hline Risk Indicator & $\underline{\text { Criterion }}$ & Score \\
\hline \multirow[b]{3}{*}{ 1. Enrollment } & $<1,000$ & 2 \\
\hline & $1,000 \leq \mathrm{x}<2,500$ & 1 \\
\hline & $\geq 2,500$ & 0 \\
\hline \multirow{2}{*}{ 2. Religious affiliation } & yes & 1 \\
\hline & no & 0 \\
\hline \multirow[b]{2}{*}{ 3. Part-time students } & $<3.0(\mathrm{FT} / \mathrm{PT})$ & 1 \\
\hline & $\geq 3.0(\mathrm{FT} / \mathrm{PT})$ & 0 \\
\hline \multirow[b]{2}{*}{ 4. Tuition discounting } & $>60 \%$ & 1 \\
\hline & $\leq 60 \%$ & 0 \\
\hline \multirow[b]{2}{*}{ 5. Tuition dependency } & $>85 \%$ & 1 \\
\hline & $\leq 85 \%$ & 0 \\
\hline \multirow[b]{2}{*}{ 6. Interest expense } & $>10 \%$ of budget & 1 \\
\hline & $\leq 10 \%$ of budget & 0 \\
\hline \multirow[b]{2}{*}{ 7. Net revenue } & $<\$ 0$ & 1 \\
\hline & $\geq \$ 0$ & 0 \\
\hline \multirow[b]{2}{*}{ 8. Endowment } & $<3.0$ (LTP/budget) & 1 \\
\hline & $\geq 3.0$ (LTP/budget) & 0 \\
\hline
\end{tabular}

To facilitate comparison with FRCS results, each component of the MRA will be scaled to the FRCS range of -1.0 to 3.0 and added in the following proportions:

Figure 9: Modified Risk Assessment (MRA) Index Composite Calculations

\begin{tabular}{|c|r|}
\hline Financial Ratios (75\%) & \\
\hline Primary Reserve Ratio & $25.0 \%$ \\
\hline Equity Ratio & $12.5 \%$ \\
\hline Return on Net Assets Ratio & $12.5 \%$ \\
\hline Net Operating Revenues Ratio & $25.0 \%$ \\
\hline Non-Financial Risk Factors (25\%) & $25.0 \%$ \\
\hline MRA Composite & $100 \%$ \\
\hline
\end{tabular}


The result of the above calculations will yield an MRA score for each year, presented on a scale of -1.0 to 3.0 .

\section{Weighted Multi-Year Composite}

Following the guidance of the Composite Financial Index, financial ratio analysis becomes more meaningful as a reflection of long-term financial stability when averaged across three years. However, because assessing long-term stability is only one primary objective of the MRA and would misstate the current financial condition of a college at risk of closure, it is essential to adapt this rationale to the purpose by weighting the results more heavily toward the current year. The practice of using a weighted moving average has concrete precedence in financial analysis, particularly in calculating ratio analyses over time (Holt, 2004). The MRA Index will be weighted $50.0 \%$ toward current year (3x), 33.3\% toward prior year (2x), and $16.7 \%$ toward prior-prior year $(1 \mathrm{x})$.

The following chart illustrates graphically the sensitivity to three different methods of calculating MRA scores for a sample college that closed in 2012. The solid blue line represents the FRCS, which is calculated annually and shows the greatest fluctuation. The dotted purple line represents the MRA score calculated annually. The dashed red line represents the MRA score with a non-weighted three-year average. The solid orange line represents the MRA score as this study intends, calculated with a weighted three-year average. 


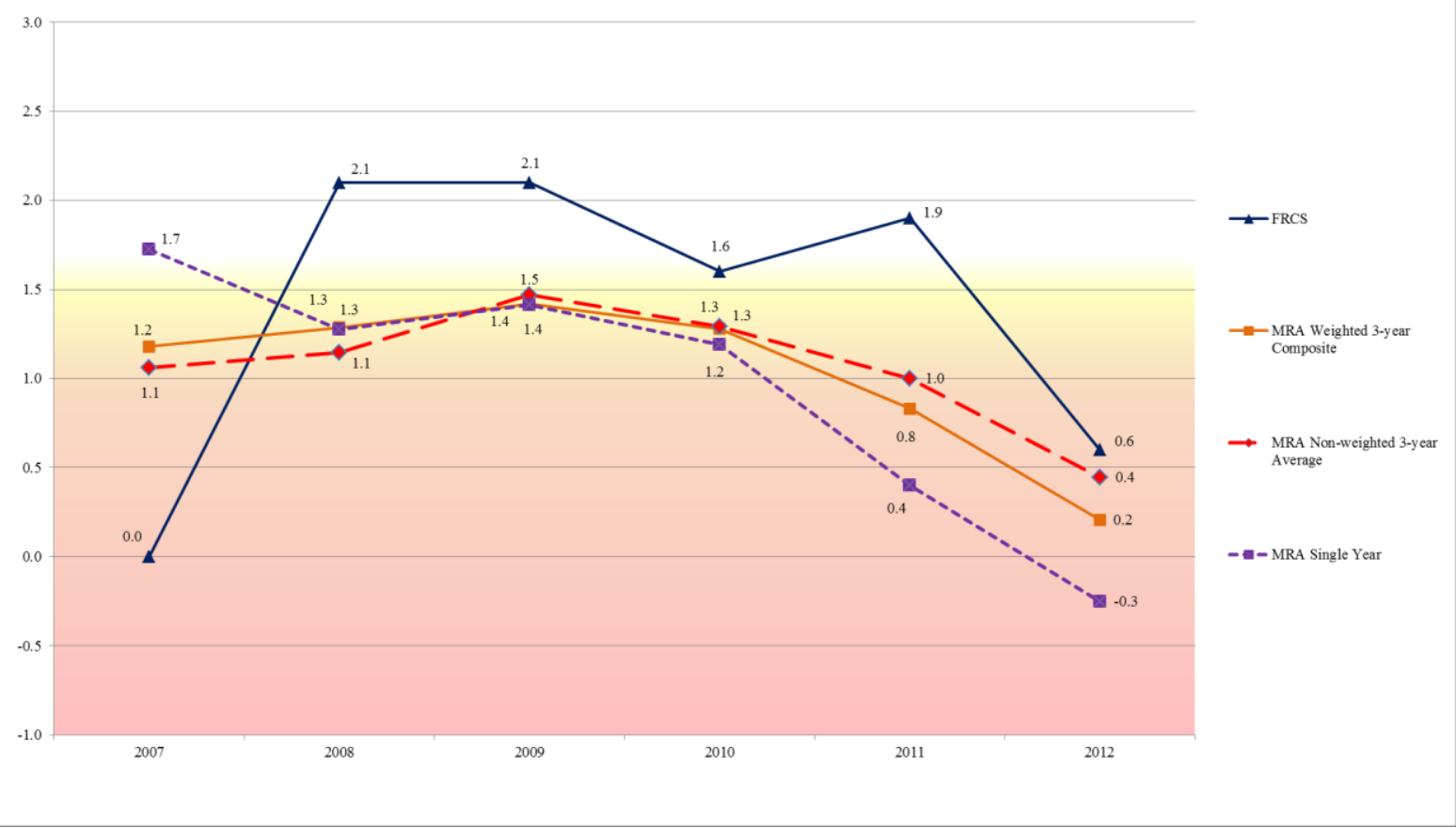

As expected, the purple one-year MRA score shows the greatest fluctuation of the three MRA scores, and the orange weighted MRA score remains consistently between the purple oneyear MRA score and the red non-weighted MRA score. In the case of this now-defunct college, the purple one-year MRA appears to perform best in predicting its closure in both its penultimate year (0.4) and its final year (-0.3), though it should be noted that that orange weighted MRA score identifies the college as failing financial standards in both years as well (0.8 and 0.2).

Taken together as a holistic valuation of financial health, the components included in the Modified Risk Assessment are supported in the literature by both theory and practice, and provide a more complete picture of higher education activities than the three ratios used by the Financial Responsibility Composite Score index. Data will be entered into the following spreadsheet in order to compare MRA scores with FRCS. 
Figure 11: Modified Risk Assessment Index Detail

\begin{tabular}{|c|c|c|c|c|c|c|c|c|c|}
\hline Year & 2004 & 2005 & 2006 & 2007 & 2008 & 2009 & 2010 & 2011 & 2012 \\
\hline \multicolumn{10}{|l|}{ MRA Composite Index } \\
\hline \multicolumn{10}{|l|}{ FRCS } \\
\hline & & & & & & & & & \\
\hline \multicolumn{10}{|l|}{ Index Components } \\
\hline \multicolumn{10}{|c|}{ Primary Reserve Ratio (25\%) } \\
\hline \multicolumn{10}{|l|}{ Equity Ratio (12.5\%) } \\
\hline \multicolumn{10}{|c|}{ Return on Net Assets Ratio (12.5\%) } \\
\hline \multicolumn{10}{|c|}{ Net Operating Revenues Ratio (25\%) } \\
\hline \multicolumn{10}{|l|}{ Risk Factors (25\%) } \\
\hline MRA Composite Single Year & & & & & & & & & \\
\hline
\end{tabular}

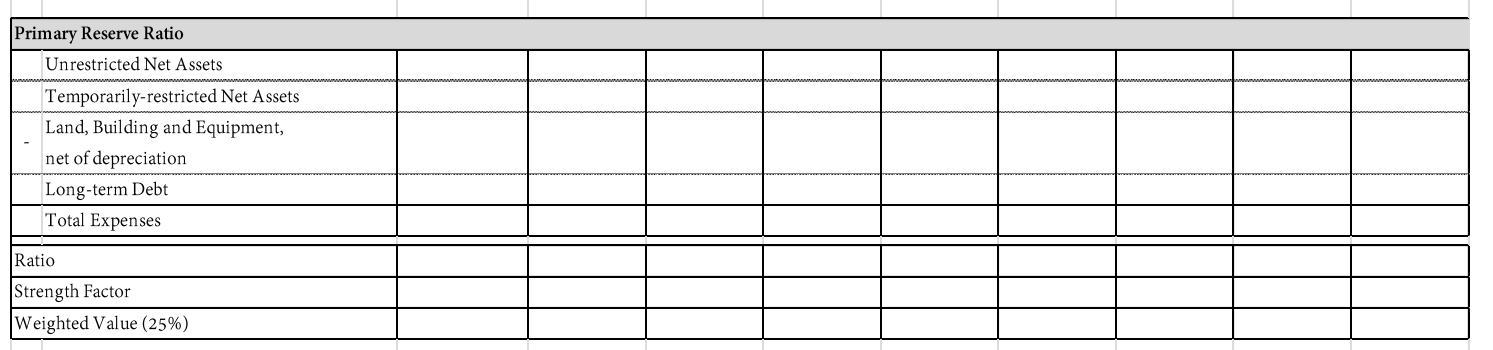

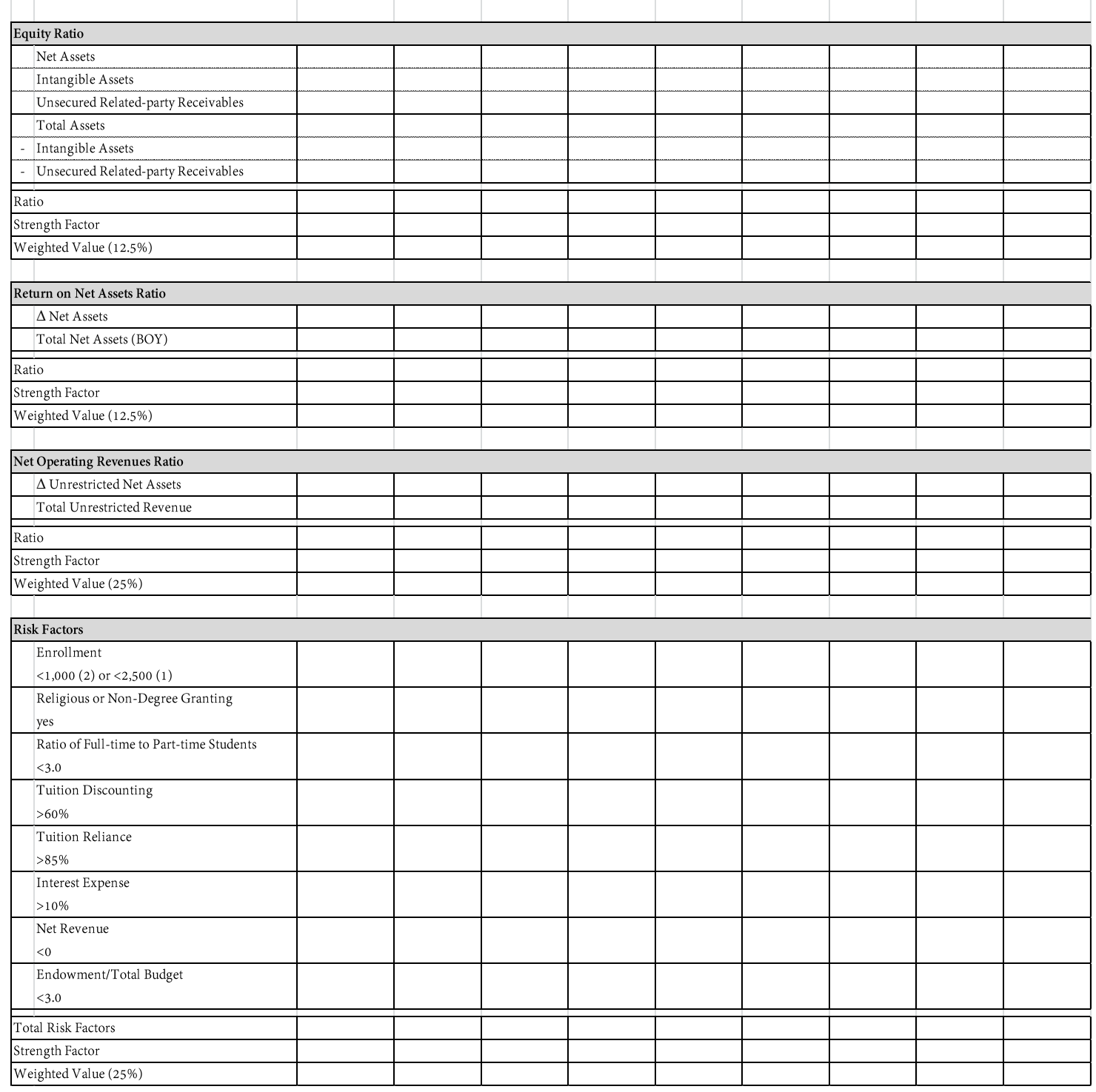




\section{Data Collection}

In this study, data will be gathered from two sources: the Integrated Postsecondary Education Data System (IPEDS) and Internal Revenue Service (IRS) Forms 990, obtained through Guidestar. All private, non-profit organizations must file an annual return to the IRS using Form 990 in order to maintain their tax exempt status. Guidestar, a non-profit service founded with a mission of increasing the efficiency and transparency of charitable giving, disseminates those forms as they are released. Form 990 contains a wide range of data on an institution's financial condition, including the several components of the ratio analyses in this study: e.g. Net Assets; Unrestricted Net Assets; Total Expenses; Land, Building and Equipment, net of depreciation; etc. The full Form 990 is presented in Appendix D.

The population to be studied will be limited to distressed private colleges identified by one of two means:

- Group 1: colleges that have closed due to financial exigency

- Group 2: colleges that are currently open, but were awarded at least one failing FRCS score (-1.0 to 0.9) during the years 2006-2013. 
As these populations are correlated to Type I and Type II errors:

\section{Figure 12: Research Population Matrix}

\begin{tabular}{|c|c|c|c|}
\hline \multirow{2}{*}{ 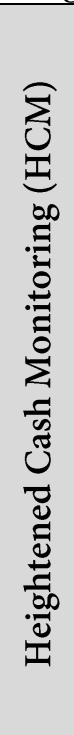 } & $\begin{array}{c}\text { GROUP 2: } \\
\text { Failing } \\
\text { FRCS scores } \\
{[-1.0,0.9]}\end{array}$ & $\begin{array}{l}\text { Colleges in Group } 1 \text { \& Group 2: } \\
\text { FRCS accurately identifies colleges at risk } \\
\text { of closure (FRCS score - } 1.0 \text { to } 0.9 \text { ) } \\
\text { Result: ED closely monitors and } \\
\text { administers Title IV funding before } \\
\text { closure }\end{array}$ & $\begin{array}{l}\text { Type I Errors: } \\
\text { Colleges in Group } 2 \text { but not in Group 1; } \\
\text { FRCS inaccurately awards a failing score } \\
(-1 \text { to } 0.9) \text { to financially stable colleges } \\
\text { Result: stable colleges incur unnecessary } \\
\text { financial and/or reputational costs }\end{array}$ \\
\hline & $\begin{array}{c}\text { Colleges not } \\
\text { placed on } \\
\text { HCM }\end{array}$ & $\begin{array}{l}\text { Type II Errors: } \\
\text { Colleges in Group } 1 \text { but not Group 2; } \\
\text { FRCS inaccurately awards a passing score } \\
\text { (1.0 to 3.0) to colleges at risk of } \\
\text { precipitous closure } \\
\text { Result: students and taxpayers incur } \\
\text { preventable losses }\end{array}$ & $\begin{array}{l}\text { Colleges in neither Group } 1 \text { nor 2: } \\
\text { FRCS accurately identifies financially } \\
\text { stable colleges (FRCS score } 1.0 \text { to } 3.0 \text { ) } \\
\text { Result: stable colleges avoid unnecessary } \\
\text { financial and/or reputational costs }\end{array}$ \\
\hline & & $\begin{array}{l}\text { GROUP 1: } \\
\text { Colleges that have closed }\end{array}$ & Financially Stable \\
\hline & & \multicolumn{2}{|c|}{ Financial Health } \\
\hline
\end{tabular}

The overlap of these two groups (upper-left quadrant) exhibits the accuracy of the FRCS index in identifying colleges in financial distress. Colleges in Group 1 that are not in Group 2 (lower-left quadrant) represent the population of Type II errors, i.e. those institutions that were truly in financial distress but were misidentified by the FRCS index as financially viable. Colleges in Group 2 that are not in Group 1 (upper-right quadrant) represent the population of Type I errors, i.e. those institutions that might claim to have been unfairly placed on HCM2 despite being financially viable.

\section{Limitations of the Research Design}

Any attempts to improve the Financial Responsibility Composite Score must be cognizant of the challenges confronting any assessment tool of higher education financial health. 
The limitations of this research design include: 1) reduced generalizability, 2) complexity of college financial statements, 3) reliability of data, and 4) inherent flaws of ratio analysis.

The diversity of the American higher education system is one of its greatest attributes, but also complicates any attempt to evaluate all institutions with any one broad instrument, particularly in the financial arena. Each subsector of higher education-public, private nonprofit, and for-profit proprietary—follows its own set of accounting guidelines that allows for subtle interpretations in reporting and also makes interinstitutional comparisons between sectors difficult. This study will focus entirely on small, private, non-profit institutions, and though the results should be tentatively generalizable to public and for-profit institutions, any enhancements to the FRCS will first need to be tested on those populations as well.

Besides the diversity across higher education, colleges and universities themselves are also quite complex on an individual level. Compared to many for-profit industries — and particularly the simpler manufacturing firms from which early forms of financial analysis originated in the late $19^{\text {th }}$ and early $20^{\text {th }}$ centuries (Horrigan, 1968)-higher education institutions have financial statements reflecting many different revenue streams and a unique combination of expenditure relationships. Caution should be used whenever distilling multifaceted financial data to a small number of usable ratios (DiSalvio, 1989).

Since 1993, enhanced accounting guidance from FASB has improved interinstitutional comparisons of college financial data, but because of the complexity of college finances and the less rigid standards applied to non-profit organizations, slight variability of accounting practices still exists. Even more significantly, data repositories such as IPEDS that rely on self-reported financial information are subject to human error. This study will include efforts to check for conspicuous inconsistencies of data across years. 
Finally, financial ratios are powerful tools of analysis, but no single approach is without flaws. As an alternative to ratios, management accounting tools such as variance analysis can provide deeper information that might prove more useful in strategic decision-making. Financial ratios, on the other hand, are best when interpreted in context along with other ratios, which makes the choice of the set of ratios very important. Another issue in using financial ratios is while they can be indispensable in making comparisons over time, any researcher should be cognizant of the fact that inflation can distort the effect of relationships either within a single institution or among several.

Nevertheless, while no research design is without limitations, the methodological approach presented in this study is grounded in both research and practice, and is intended to add to the body of knowledge on financial assessment in higher education. 


\section{Chapter 4: Findings}

The goal of this research is to investigate the ability of a model of analysis to differentiate between colleges at risk of closure and colleges that are financially stable, and is designed to answer two primary research questions:

1. How accurately does the Department of Education's Financial Responsibility Composite Score differentiate between colleges at risk of closure and colleges that are financially stable?

2. Does an alternate model better differentiate between colleges at risk of closure and colleges that are financially stable?

\section{FRCS and Predicting College Closure}

Evaluating the ability of the Financial Responsibility Composite Score to predict precipitous closure is relatively straightforward: colleges that have closed due to financial exigency are easily identified. The Department of Education publishes a list of all Title IV recipients that have closed since 1984, and also has made publicly available the list of FRCS scores for all non-profit and for-profit colleges during the years 2007 through 2013. A crosscomparison of those two lists reveals 31 private colleges for which FRCS scores are available.

According to the National Center for Education Statistics (2015, Table 317.50), across the same time period, a total of 104 colleges and universities have closed their doors. That number includes 32 private non-profits, 66 for-profits, and 6 publics. Of the 32 private nonprofits, one institution is not included on the FRCS scores reported by ED, potentially either because it did not participate in Title IV funding or because of a reporting discrepancy by ED. 
The table below indicates the final two FRCS scores for the 31 private, non-profit colleges for which data is available since 2007.

Figure 13: Private, Non-Profit Colleges Closed Since 2007

\begin{tabular}{|c|c|c|c|c|}
\hline \multirow{2}{*}{ Institution } & \multirow{2}{*}{ Location } & \multirow{2}{*}{$\begin{array}{c}\text { Year } \\
\text { Closed }\end{array}$} & \multicolumn{2}{|c|}{ FRCS Score } \\
\hline & & & penultimate & final year \\
\hline Antioch University & Yellow Springs, $\mathrm{OH}$ & $2008 \dagger$ & 3.0 & 2.4 \\
\hline Southeastern University & Washington, DC & 2009 & \#N/A & 1.5 \\
\hline Dana College & Blair, NE & 2010 & 0.6 & 0.6 \\
\hline Rabbinical Seminary Of Adas Yereim & Brooklyn, NY & 2010 & \#N/A & 3.0 \\
\hline Samra University of Oriental Medicine & Los Angeles, CA & 2010 & 2.3 & 0.6 \\
\hline Beacon University & Columbus, GA & 2011 & \#N/A & 0.2 \\
\hline Bethany University of the Assemblies of God & Scotts Valley, CA & 2011 & 2.2 & 2.3 \\
\hline Cleveland Chiropractic College & Los Angeles, CA & 2011 & 2.6 & 2.3 \\
\hline Southern Catholic College & Dawsonville, GA & 2011 & \#N/A & -0.9 \\
\hline Southern New England School of Law & North Dartmouth, MA & 2011 & 3.0 & -0.4 \\
\hline Springfield College Illinois & Springfield, IL & 2011 & 1.1 & 1.3 \\
\hline Atlantic Union College & South Lancaster, MA & $2011+$ & 1.5 & 1.3 \\
\hline Bethany Global University & Bloomington, $\mathrm{MN}$ & 2012 & \#N/A & -1.0 \\
\hline Chester College of New England & Chester, $\mathrm{NH}$ & 2012 & 1.9 & 0.6 \\
\hline Lambuth University & Jackson, TN & 2012 & 0.0 & -0.2 \\
\hline Messenger College & Joplin, MO & 2012 & 1.9 & 2.7 \\
\hline Wesley College & Florence, MS & 2012 & 2.2 & -0.2 \\
\hline Bangor Theological Seminary & Bangor, ME & 2013 & 2.2 & 2.2 \\
\hline College of Visual Arts & St Paul, MN & 2013 & 1.9 & 1.6 \\
\hline Mountain State University & Beckley, WV & 2013 & 3.0 & 2.2 \\
\hline Saint Paul's College & Lawrenceville, VA & 2013 & 1.7 & 2.0 \\
\hline Calvary Baptist Theological Seminary & Lansdale, PA & 2014 & 1.6 & 2.8 \\
\hline Lexington College & Chicago, IL & 2014 & 1.0 & -0.7 \\
\hline Mid-Continent University & Mayfield, KY & 2014 & 3.0 & 3.0 \\
\hline National Labor College & Silver Spring, MD & 2014 & -0.5 & -0.7 \\
\hline Thunderbird School of Global Management & Glendale, AZ & 2014 & 1.8 & 1.5 \\
\hline Virginia Intermont College & Bristol, VA & 2014 & 1.4 & 0.3 \\
\hline Marian Court College & Swampscott, MA & 2015 & 2.3 & 1.1 \\
\hline Sojourner-Douglass College & Baltimore, MD & 2015 & 0.7 & -1.0 \\
\hline Sweet Briar College & Sweet Briar, VA & $2015^{*}$ & 2.2 & 3.0 \\
\hline Robert B. Miller College (The) & Battle Creek, MI & $2016^{* * *}$ & -1.0 & -0.6 \\
\hline
\end{tabular}

$\dagger$ Antioch College closed in 2008 due to financial exigency and reopened in 2011

\#Atlantic Union College closed in 2011 due to financial exigency and reopened in 2015

*Sweet Briar College announced its impending closure in March 2015 due to financial exigency; in June, the Virginia Attorney General ruled to lift legal restrictions on endowed funds, allowing the college to remain open **The Robert B. Miller College recently announced that it will close in 2016 due to financial exigency 
The data above indicate that the FRCS was able to identify only 5 of 31 colleges (16 percent) as at risk of closure in their penultimate year of operation, which would have allowed ED to apply strict oversight of Title IV funds and perhaps to better inform students and prospective students of their academic and financial options. More remarkably, in their final year- even after many of these colleges have declared publicly that they are no longer financially solvent - the table above indicates that fewer than half (14 of 31, or 45\%) could be identified by the FRCS as financially distressed. The stated goal of the metric is to identify colleges lacking "sufficient resources to ensure against the precipitous closure of the institution" (Higher Education Act of $1965, \S 498(c)$ ). Because of the potentially high cost of Type II errors, this study established an $80 \%$ acceptability threshold for the two-year time period. Based on the above analysis revealing $16 \%$ accuracy across a two-year time frame and $45 \%$ across one year, the Financial Responsibility Composite Score metric appears to be failing in its mission.

\section{FRCS and Identifying Financially Stable Colleges}

By most accounts, the FRCS was reasonably effective and stable for the first decade until the financial shocks of 2008-2009 exposed a weakness of the metric (National Association of Independent Colleges and Universities, 2012). Because the arithmetic of the FRCS formula accounts for investment losses as an operating expense, institutions with the largest endowments were penalized by the size of investment loss without reflecting the more obvious benefit of their extraordinary remaining reserves. As observed with humor by the National Association of Independent Colleges and Universities (NAICU) Task Force (2012), a confounding effect of the flaw was the favorable comparison of Leon's Beauty School (FRCS 3.0) to Harvard University (FRCS 2.2), despite the fact that Harvard's remaining endowment of \$26 billion (Harvard 
Magazine, 2009) could presumably ensure that the university was not more at risk of precipitous closure than a small beauty school with limited net assets.

Partly as a result of these market fluctuations, nearly three hundred institutions found themselves subjected to additional federal oversight for the first time due to the result of the 2009 FRCS scores. While it would be expected that a historic market correction such as experienced in 2008-2009 could place significant financial pressure on any colleges without adequate reserves, it is instead more likely that the peculiarity of the FRCS formula caused so many financially stable colleges to be inaccurately awarded failing scores in 2009. The following table shows a sample of 20 private, non-profit institutions that represent hundreds of possible examples.

Figure 14: Colleges Unexpectedly Placed on HCM in 2009

\begin{tabular}{|l|l|r|r|r|r|r|r|r|}
\hline \multicolumn{1}{|c|}{ Institution Name } & \multicolumn{1}{|c|}{ Location } & $\mathbf{2 0 0 7}$ & $\mathbf{2 0 0 8}$ & $\mathbf{2 0 0 9}$ & $\mathbf{2 0 1 0}$ & $\mathbf{2 0 1 1}$ & $\mathbf{2 0 1 2}$ & $\mathbf{2 0 1 3}$ \\
\hline Ashland University & Ashland, OH & 2.7 & 2.3 & 1.3 & 2.3 & 2.9 & 2.7 & 2.8 \\
\hline Baker University & Baldwin City, KS & 3.0 & 2.2 & 0.6 & 2.0 & 2.9 & 3.0 & 2.4 \\
\hline Brenau University & Gainesville, GA & 3.0 & 2.2 & 1.2 & 2.8 & 3.0 & 2.6 & 3.0 \\
\hline Cambridge College & Cambridge, MA & 2.3 & 2.0 & 1.0 & 2.5 & 2.8 & 2.9 & 2.4 \\
\hline Concordia Seminary & Saint Louis, MO & 2.2 & 2.3 & 0.6 & 2.5 & 3.0 & 2.6 & 2.6 \\
\hline Dominican University & River Forest, IL & 3.0 & 2.7 & 1.2 & 2.3 & 2.5 & 1.7 & 2.6 \\
\hline Guilford College & Greensboro, NC & 3.0 & 2.2 & 1.4 & 2.5 & 2.9 & 2.5 & 3.0 \\
\hline Hamline University & Saint Paul, MN & 3.0 & 2.1 & 1.3 & 2.4 & 3.0 & 2.4 & 2.6 \\
\hline Houghton College & Houghton, NY & 3.0 & 2.6 & 1.4 & 2.6 & 2.7 & 2.9 & 2.6 \\
\hline Jacksonville University & Jacksonville, FL & 3.0 & 2.2 & 1.0 & 2.2 & 2.2 & 1.8 & 2.3 \\
\hline Kentucky Christian University & Grayson, KY & 2.8 & 2.4 & 1.1 & 2.1 & 2.6 & 2.4 & 2.8 \\
\hline Lancaster Bible College & Lancaster, PA & 3.0 & 2.5 & 1.4 & 3.0 & 3.0 & 2.9 & 3.0 \\
\hline Manchester University & North Manchester, IN & 3.0 & 2.8 & 1.0 & 2.7 & 3.0 & 3.0 & 3.0 \\
\hline Mary Baldwin College & Staunton, VA & 3.0 & 2.9 & 1.3 & 1.7 & 2.9 & 3.0 & 3.0 \\
\hline Mayo Clinic, College of Medicine & Rochester, MN & 3.0 & 3.0 & 0.8 & 2.9 & 3.0 & 2.4 & 2.3 \\
\hline McPherson College & McPherson, KS & 3.0 & 2.2 & 1.4 & 2.8 & 3.0 & 1.9 & 3.0 \\
\hline Mercer University & Macon, GA & 2.8 & 2.0 & 1.0 & 1.6 & 2.5 & 2.3 & 2.9 \\
\hline Mitchell College & New London, CT & 2.6 & 2.6 & 1.0 & 1.7 & 2.4 & 2.2 & 2.9 \\
\hline Stephens College & Columbia, MO & 2.7 & 2.2 & 0.6 & 2.0 & 3.0 & 2.3 & 3.0 \\
\hline University of Saint Thomas & Houston, TX & 3.0 & 2.5 & 0.6 & 2.0 & 2.5 & 3.0 & 2.9 \\
\hline
\end{tabular}

ED considers any college with a score of 1.5 or higher to be "financially responsible without further oversight." In the case of these 20 examples, the remarkable strength of their scores in 
every other year appears to confirm the criticism of the flawed FRCS metric and its inability to accurately identify financially stable colleges.

Together, the first two parts of this study propose an answer to the first research question: how accurately does the Department of Education's Financial Responsibility Composite Score differentiate between colleges at risk of closure and colleges that are financially stable? The FRCS predicted the precipitous closure of only 5 of 31 colleges since 2007, suggesting that the metric is not very effective in identifying colleges at risk of precipitous closure. Conversely, while acknowledging that it is difficult to define precisely a forward-looking population of financially stable colleges, an analysis of FRCS scores from 2009 exposes a weakness in the formula that appears to prevent the FRCS from differentiating accurately between distressed and stable colleges.

\section{Developing an Alternate Model}

To address the problem of practice, this study has developed an alternate model, the Modified Risk Assessment (MRA) Index, and has applied it to an extensive financial analysis of 25 private, non-profit colleges in the years 2004 through 2014. The sample population includes all five closed institutions from the higher education sector classified by the Carnegie Classification as private colleges with an enrollment profile oriented toward bachelor's degrees:

1. Chester College of New England (Chester, NH)

2. Dana College (Blair, NE)

3. Lambuth University (Jackson, TN)

4. Mid-Continent University (Mayfield, KY)

5. Virginia Intermont College (Bristol, VA)

Added to that population is a group of 20 presently-open private, non-profit, bachelor's-oriented institutions that have received at least one failing FRCS score (-1.0 to 0.9) between 2007 and 2013: 
1. Bethany College (Lindsborg, KS)

2. Birmingham Southern College (Birmingham, AL)

3. Brevard College (Brevard, NC)

4. Caldwell College (Caldwell, NJ)

5. Catawba College (Salisbury, NC)

6. Eureka College (Eureka, IL)

7. Georgetown College (Georgetown, KY)

8. Greensboro College (Greensboro, NC)

9. MacMurray College (Jacksonville, IL)

10. Ohio Valley University (Vienna, WV)

11. Olivet College (Olivet, MI)

12. Rochester College (Rochester Hills, MI)

13. Saint Paul's College (Lawrenceville, VA)

14. St. Andrews Presbyterian College (Laurinburg, NC)

15. Sterling College (Sterling, KS)

16. Stillman College (Tuscaloosa, AL)

17. Tennessee Wesleyan College (Athens, TN)

18. Vanguard University of Southern California (Costa Mesa, CA)

19. Wells College (Aurora, NY)

20. Wesleyan College (Macon, GA)

As outlined in Chapter 3, the MRA Index assesses financial strength with the following formula:

- Primary Reserve Ratio: $25 \%$

- Equity Ratio: $12.5 \%$

- Return on Net Assets Ratio: $12.5 \%$

- Net Operating Revenues Ratio: $25 \%$

- Non-Financial Risk Indicators: 25\%

For ease of comparison with the FRCS, each composite score is then scaled on the same range of -1.0 to 3.0, and then calculated on a weighted average of the most recent three years. Full financial results are included in Appendix E, with a graphic analysis below to show a comparison of the Modified Risk Assessment (MRA) Index with the federal Financial Responsibility Composite Score (FRCS).

Throughout the following 25 charts, FRCS values are shown in blue and reflect the scores reported by ED in all available years. The MRA Index is shown in orange for the same 
time period. For the ease of understanding how each score relates to the ED financial responsibility standards, these two indices are plotted against a color-coded background:

\begin{tabular}{|c|c|c|c|}
\hline Index Score & $\begin{array}{c}\text { Financial Responsibility } \\
\text { Standards Result }\end{array}$ & $\begin{array}{c}\text { Heightened Cash } \\
\text { Monitoring (HCM) Level }\end{array}$ & $\begin{array}{c}\text { Chart } \\
\text { Background }\end{array}$ \\
\hline 1.5 to 3.0 & Pass & None & white \\
\hline 1.0 to 1.4 & Probationary "Zone" & HCM1 & yellow \\
\hline-1.0 to 0.9 & Fail & HCM2 & red \\
\hline
\end{tabular}

\section{Analysis of Closed Colleges: FRCS versus the MRA Index}

The most important purpose of ED's financial analysis is to accurately predict colleges at risk of precipitous closure. Given the lack of effectiveness indicated by the analysis in part one of this study, the principal importance of this research becomes the need to improve upon that practice. The following five charts are the result of that endeavor.

Chart 1: Chester College of New England (Chester, NH)

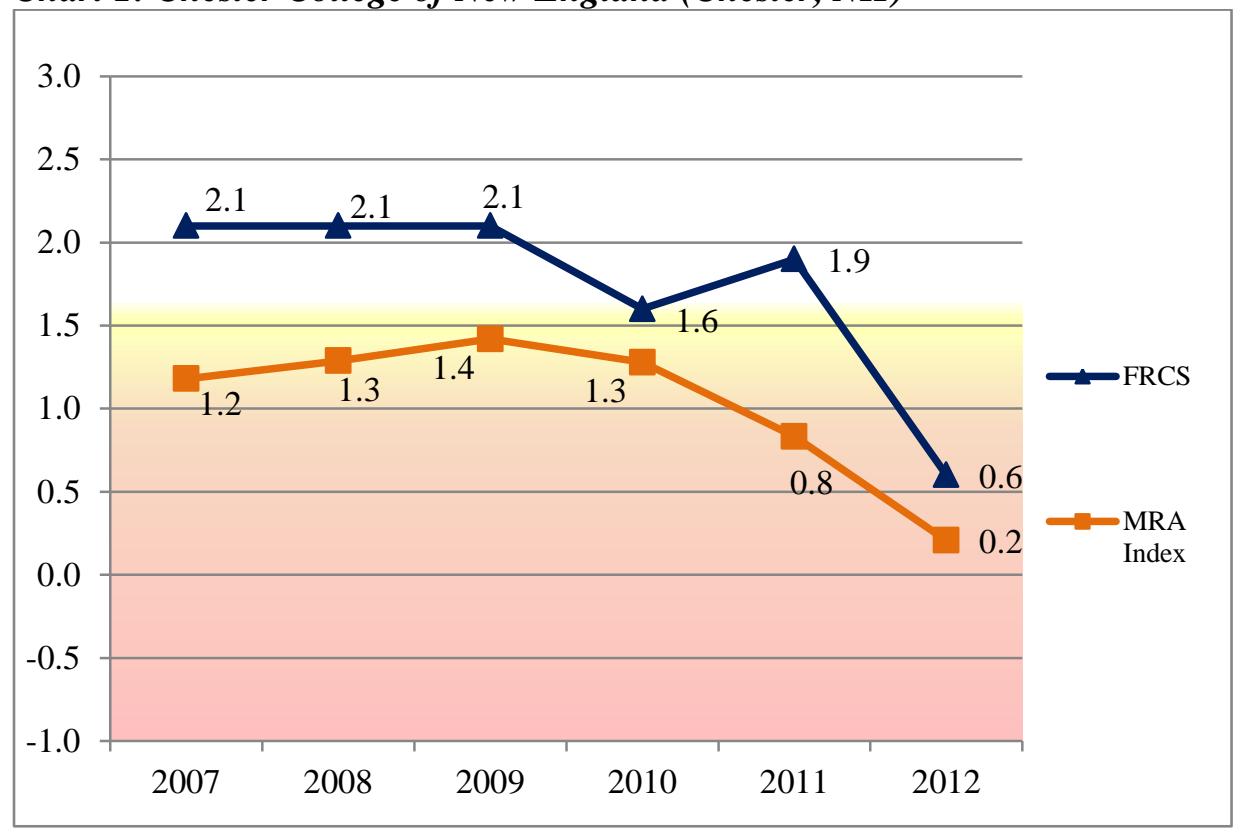

The MRA Index shows consistently lower financial health for Chester College as compared to FRCS and would have been more effective in predicting closure

In the case of now-defunct Chester College of New England, the MRA Index would have provided a significant improvement over the FRCS in predicting closure. Chester College collapsed in 2012 amidst a severe operating deficit and financial stress (Jaschik, 2012). From 
2007 through its penultimate year, 2011, the FRCS deemed Chester to be financially responsible and required no additional oversight by the Department of Education. Had the MRA Index been applied, Chester College would have been subjected to HCM1 from 2007 through 2010, and in the critical year of 2011, a score of 0.8 would have placed the distressed college on HCM2.

Chart 2: Dana College (Blair, NE)

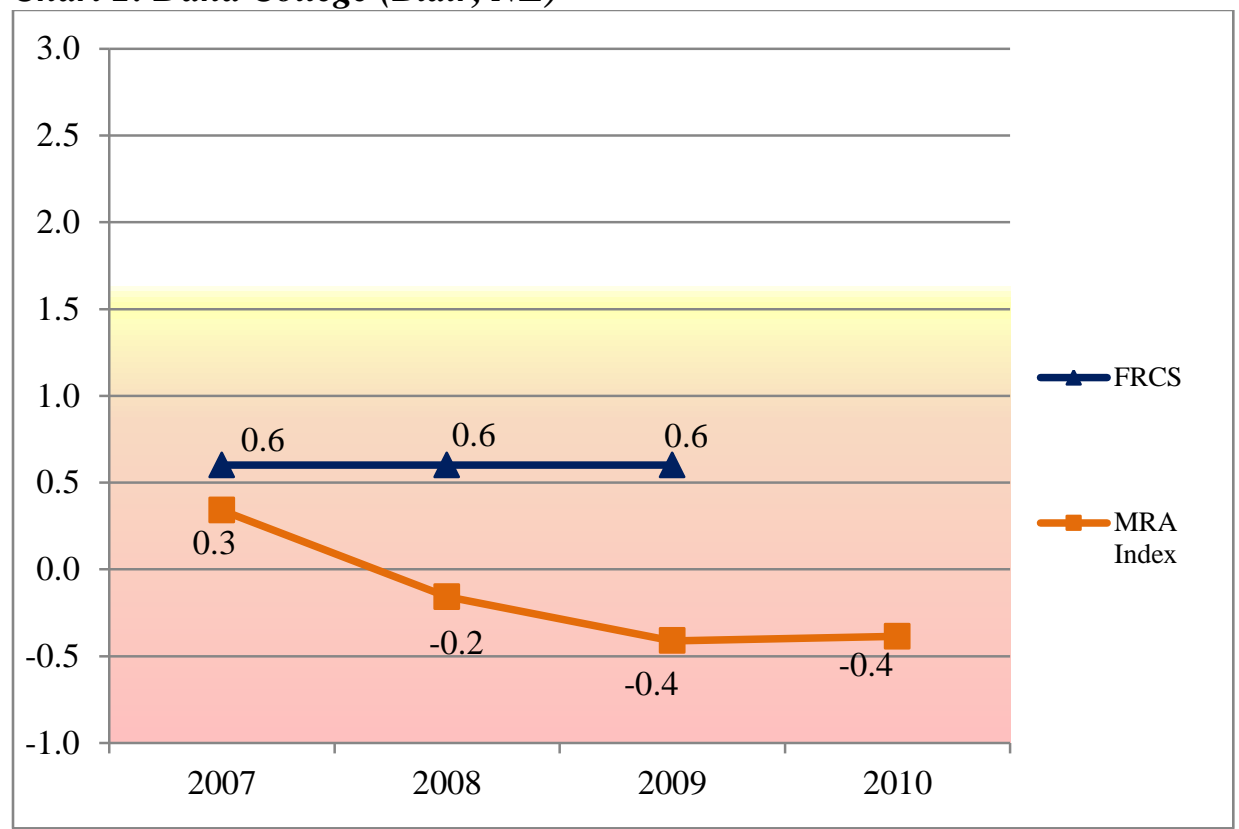

The MRA Index shows consistently lower financial health for Dana College as compared to FRCS and would have predicted closure to the same degree

For Dana College, the MRA Index would have provided a clearer picture of distress than the FRCS, though perhaps with no difference in outcome for the Department of Education. The FRCS scores of 0.6 in 2007 through 2009 were enough to place the college on HCM2 and trigger the strictest level of federal oversight. As a matter of operating protocol, it is unclear whether ED staff might have been more vigilant over a college with a score of -0.4 than 0.6 in Dana College's penultimate year; -0.4 clearly shows a more dire picture, though both are subject to strict scrutiny in HCM2. Most importantly, however, it should be noted that the MRA Index was able to identify the deteriorating financial picture while the college experienced dwindling enrollments and multimillion dollar deficits (Abourezk, 2010). 
Chart 3: Lambuth University (Jackson, TN)

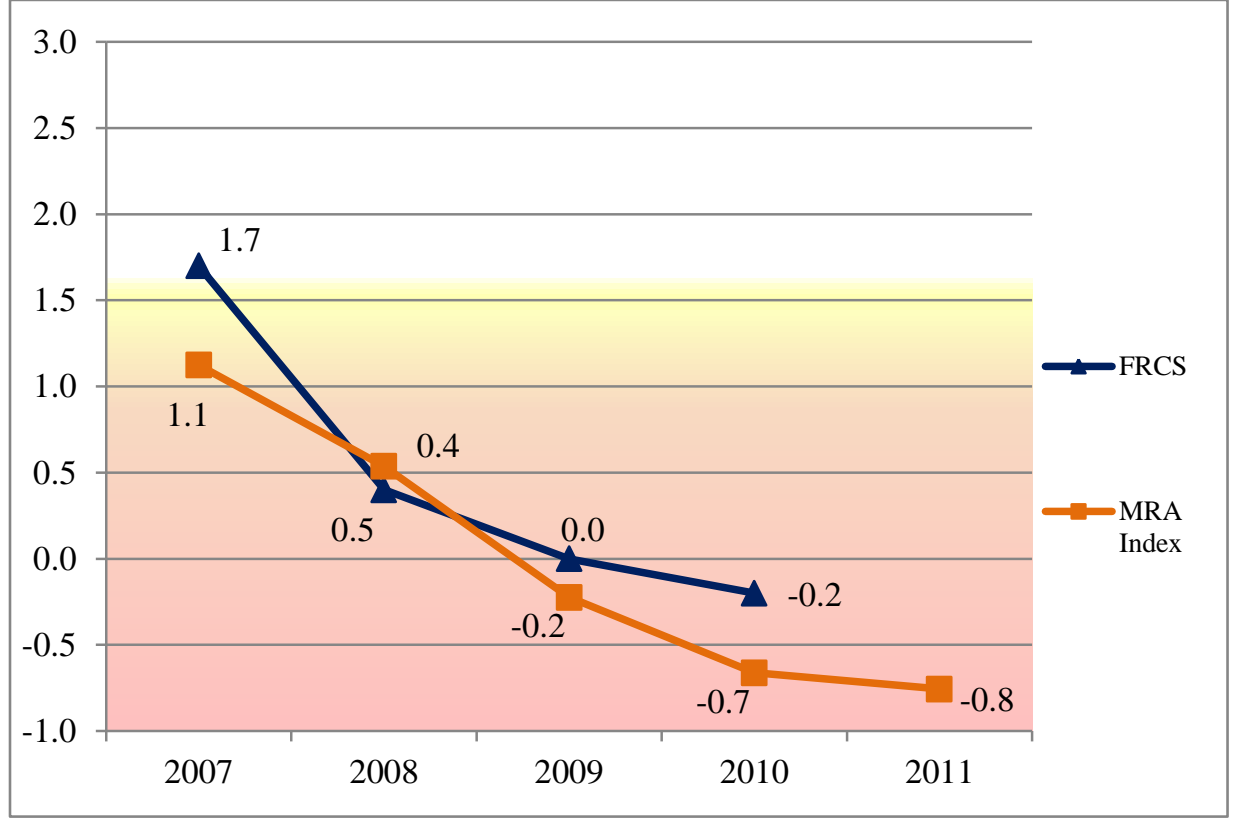

The MRA Index indicates lower financial health for Lambuth University as compared to FRCS and would have predicted closure to the same degree

Lambuth University presents a similar picture: FRCS identified Lambuth as financially distressed four years before it closed in 2011 after several years of financial struggles (Jaschik, 2011). The MRA Index would have attempted to illuminate that deteriorating picture a year earlier by placing Lambuth on HCM1 in 2007, but like Dana College, it should be noted that Lambuth University serves as evidence that FRCS was effective in alerting ED to the possibility of precipitous closure. 
Chart 4: Mid-Continent University (Mayfield, KY)

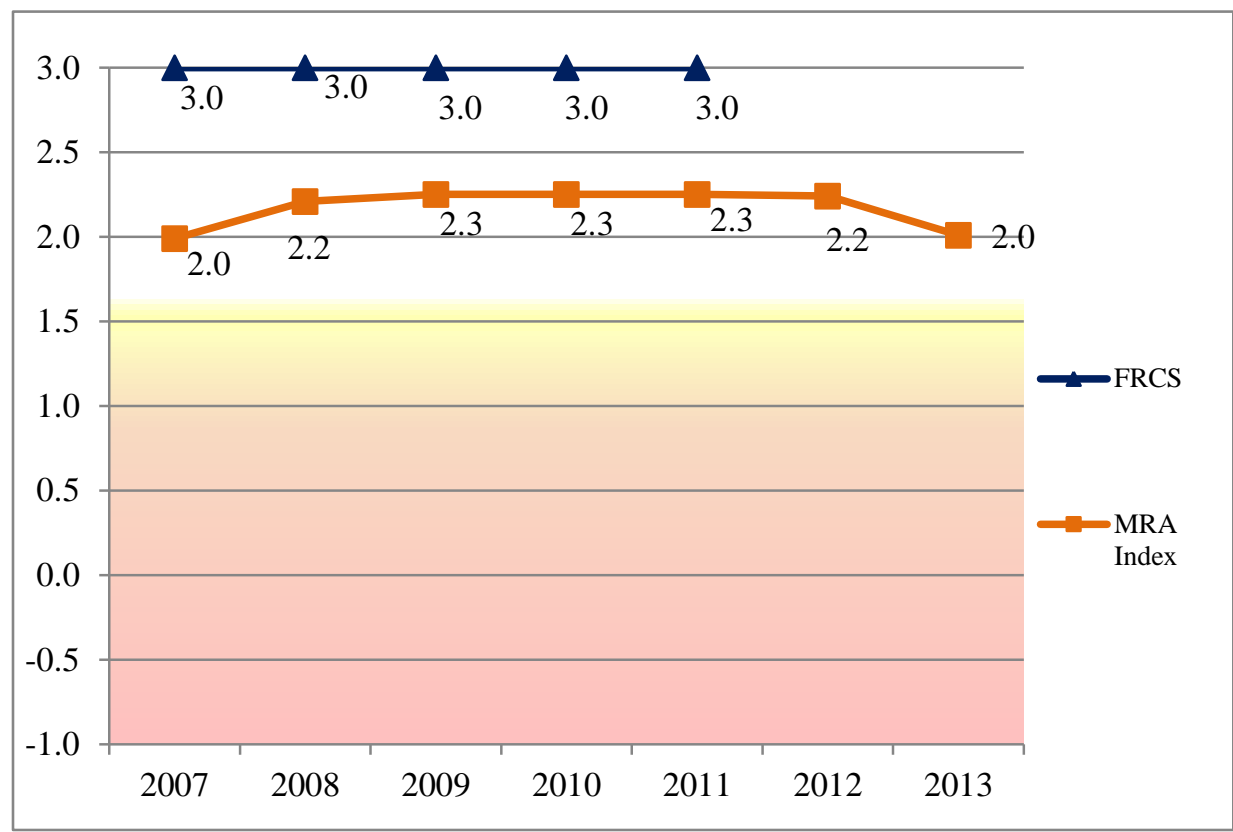

The MRA Index shows consistently lower financial health for Mid-Continent University as compared to FRCS, but would not have predicted closure

In contrast, Mid-Continent University stands as a cautionary tale against the effectiveness of either metric. Despite Mid-Continent's well-documented financial struggles in recent yearsultimately filing for bankruptcy protection with millions of dollars of unpayable debt (University Herald, 2014) — these two different analyses of its financial statements declared it to be financially stable. In fact, the FRCS consistently awarded the university its highest possible score of 3.0. While the MRA Index would have detected some flaws in Mid-Continent's financial condition, neither index would have been effective in alerting ED to the risk. 
Chart 5: Virginia Intermont College (Bristol, VA)

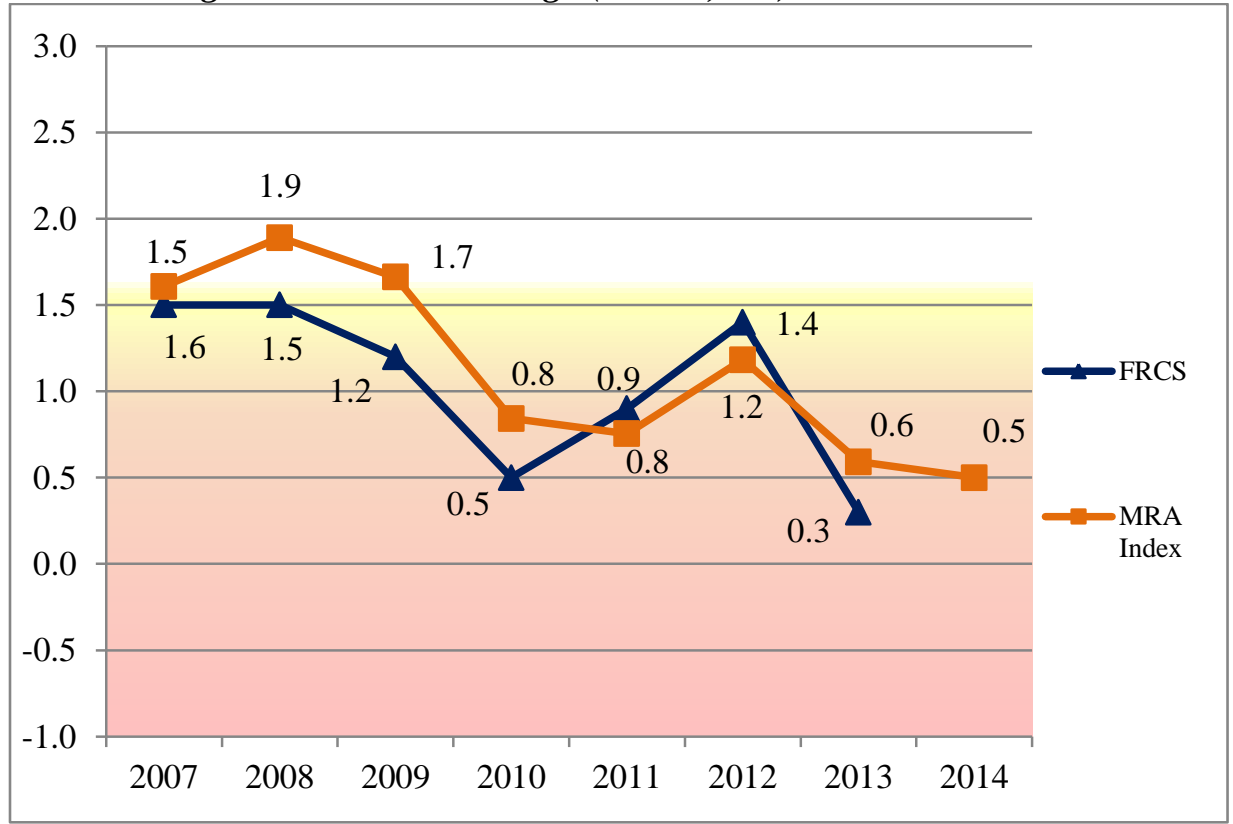

The MRA Index shows generally similar financial health for Virginia Intermont, and would have predicted closure to the same degree

With Virginia Intermont College, there is also little difference in the effectiveness of the two metrics. The FRCS distinguishes itself slightly with an earlier alert, having prompted HCM1 in 2009. Both indices accurately identified serious concerns in financial condition and should have triggered HCM2 oversight in 2010 and 2011, as well as in the important penultimate year of 2013.

In summary, these five closed private colleges constitute a small but definitive population. By applying an ex-post facto quasi-experimental design, this study attempts to evaluate whether an alternate assessment model would have been more accurate in predicting closure. In four of five now-defunct colleges, the MRA Index awarded a lower financial health rating than the FRCS; the fifth college, Virginia Intermont, did not show a significant difference.

Only in the case of Chester College would the MRA have had an unequivocally material impact on ED's awareness of the college's impending closure; the FRCS was unable to identify Chester College as failing until its final year, whereas the MRA consistently rated the college as 
worthy of HCM1 in each year, and then HCM2 in the penultimate and final years. For three other colleges, the MRA conclusively offered a lower financial health rating than the FRCS, though given ED's current operational protocol of grouping colleges into three bands and not differentiating between institutions within a band, it is not clear that the lower MRA score would have had an impact on the strength of warning.

\section{Analysis of Open Colleges: FRCS versus the MRA Index}

The additional 20 colleges in the population sample remain open, despite each sharing many characteristics with the five colleges that have already closed. In addition to individual similarities, all 25 institutions are private, non-profit colleges oriented toward conferring bachelor's degrees, all enroll fewer than 2,500 undergraduates, and all depend on net tuition as their largest source of revenue. Within that framework and without the benefit of hindsight, it is not irrefutably conclusive that all 20 open colleges are financially stable, since it is possible that several are struggling with dire financial situations now and will close in coming years. Because of that uncertainty, the task of evaluating an alternate metric on its ability to evaluate the financial strength of these colleges becomes more nuanced.

However, though that lack of finality mitigates the strength of the conclusions drawn, the task of a composite financial assessment metric is to seek vital and subtle characteristics that distinguish between organizations that appear to similar. While the future for any small college is uncertain — not to mention for 20 colleges that have been placed on publicly-released HCM reports, subjecting them to financial and reputational costs - it is still possible that all colleges that remain open are categorically different from the five colleges that have closed.

The following charts show a comparison of the FRCS versus the MRA Index for those 20 colleges, presented here in increasing order of MRA Index score in the most current year available. 
Chart 6: Rochester College (Rochester Hills, MI)

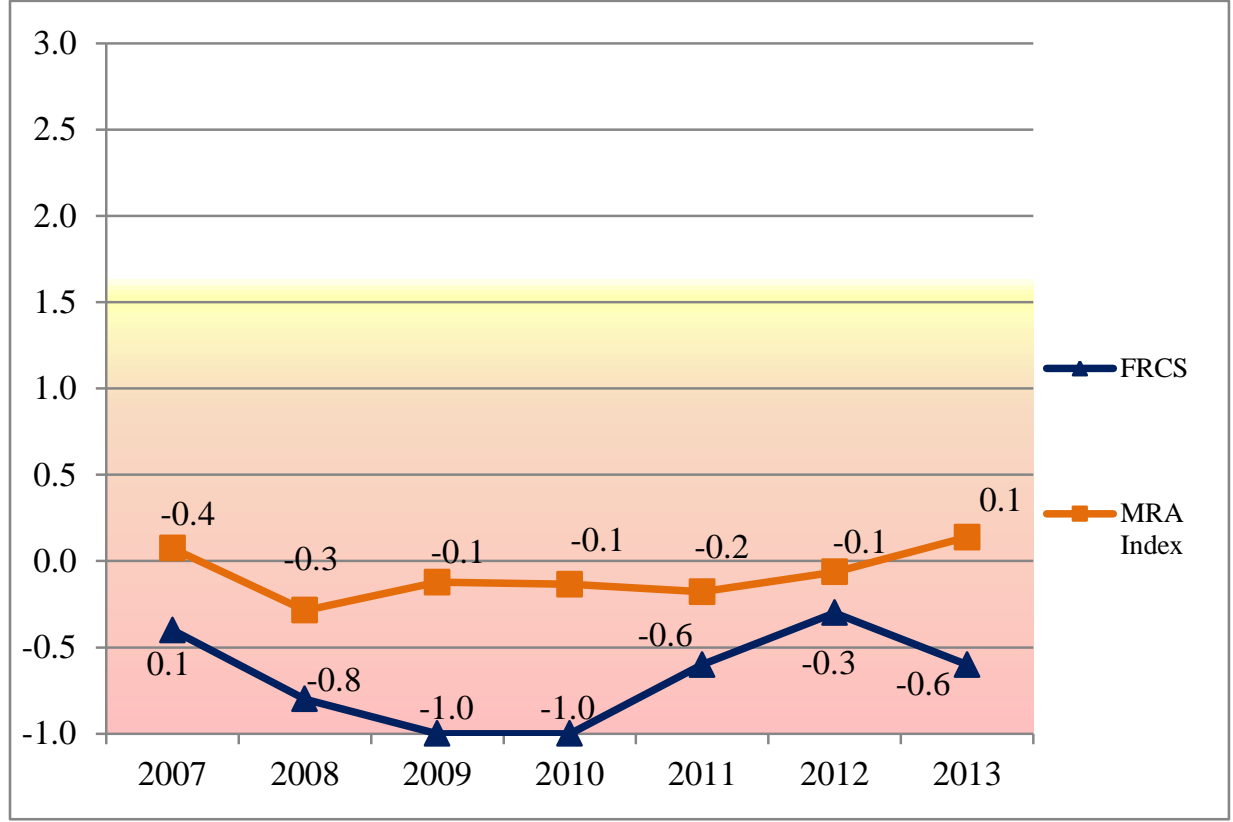

The MRA Index shows consistently better financial health for Rochester College as compared to FRCS

Chart 7: Wells College (Aurora, NY)

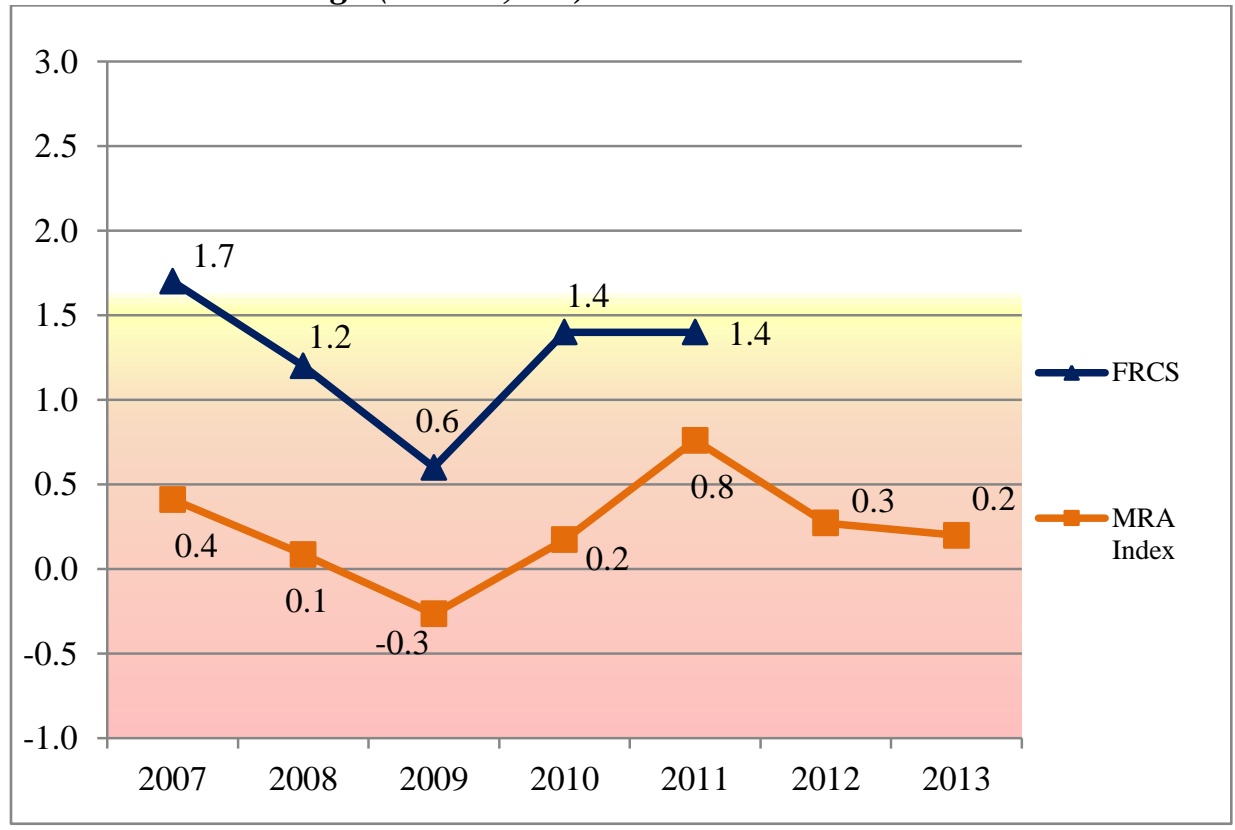

The MRA Index shows consistently lower financial health for Wells College as compared to FRCS 
Chart 8: Bethany College (Lindsborg, KS)

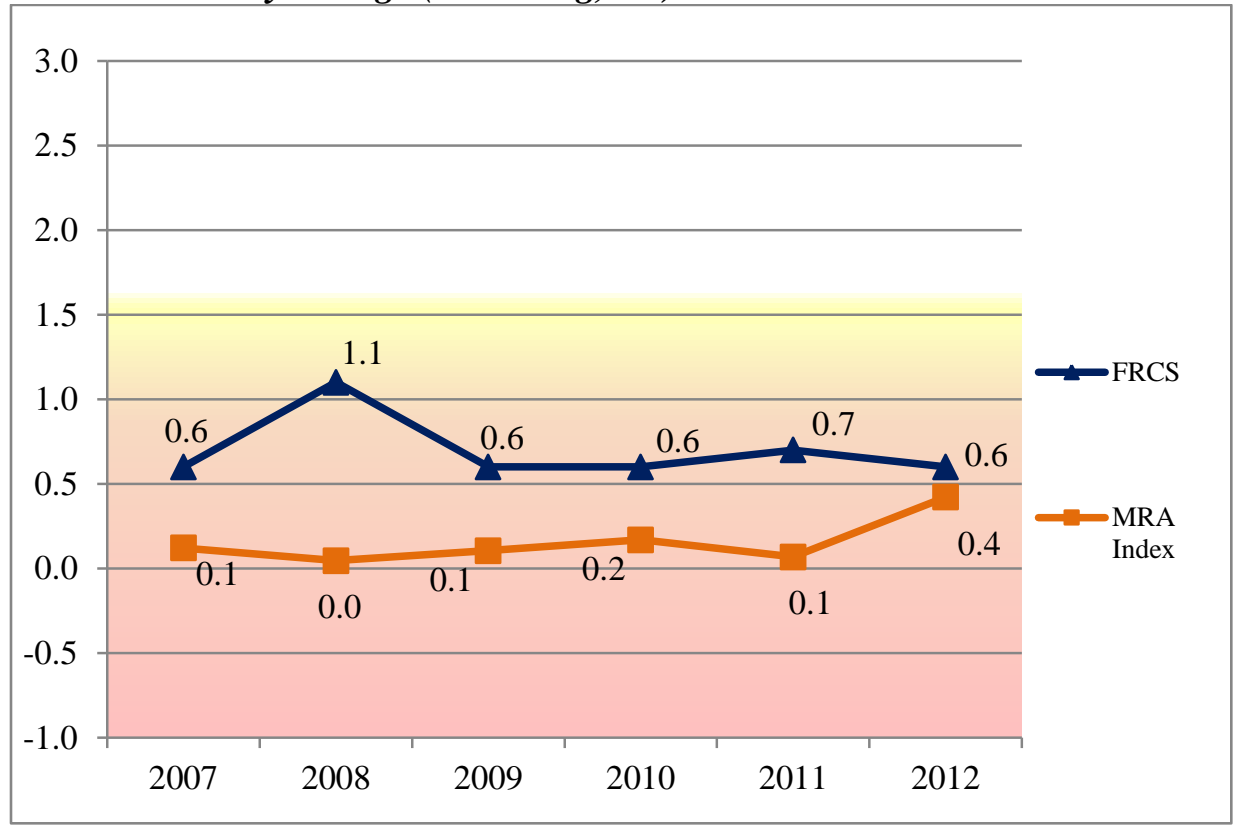

The MRA Index shows consistently lower financial health for Bethany College as compared to FRCS

Chart 9: St. Andrews Presbyterian College (Laurinburg, NC)

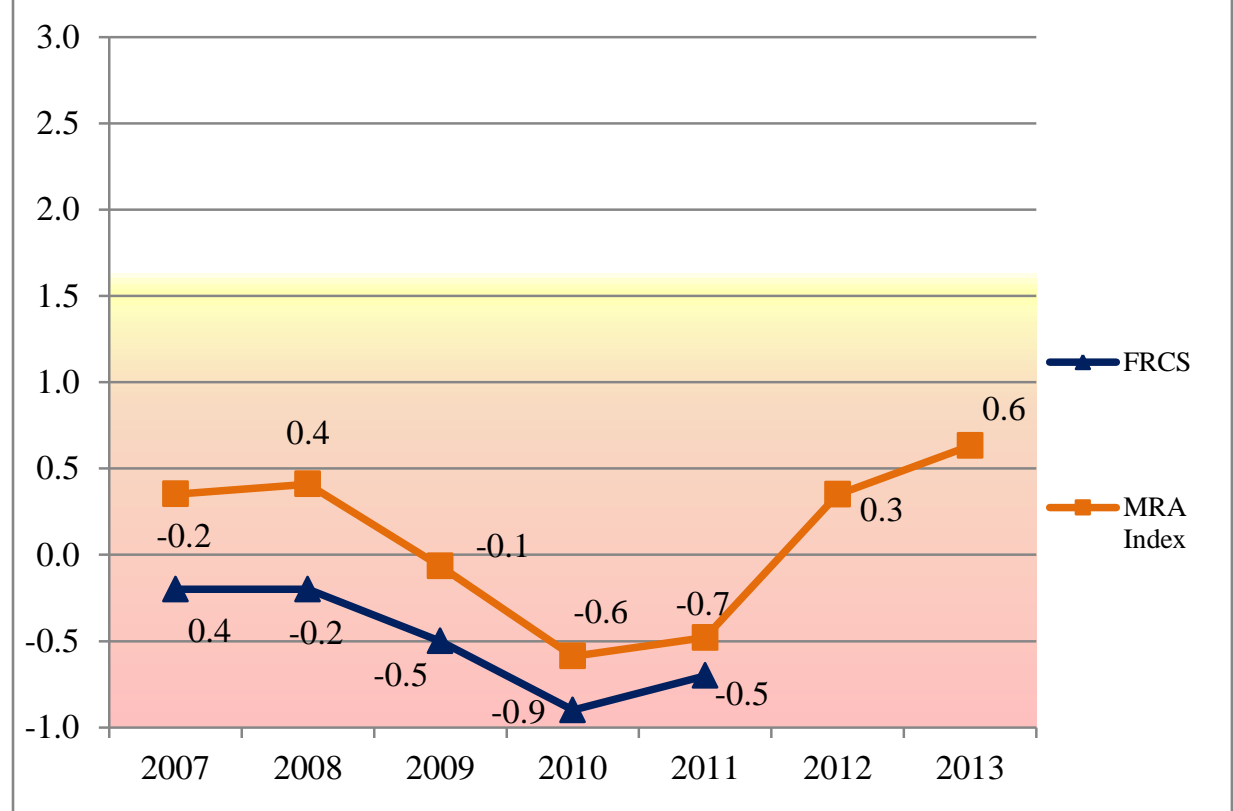

The MRA Index shows consistently better financial health for St. Andrews Presbyterian College as compared to FRCS 
Chart 10: Sterling College (Sterling, KS)

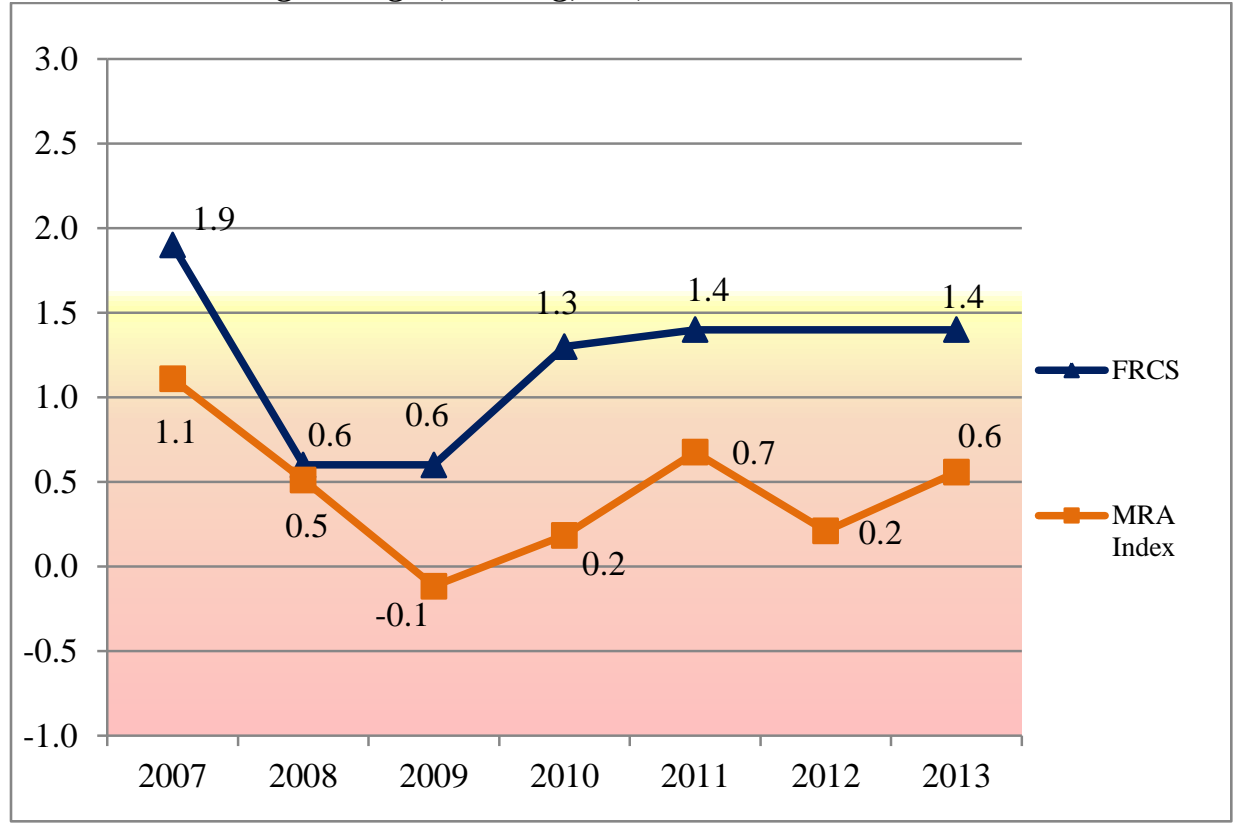

The MRA Index shows consistently lower financial health for Sterling College as compared to FRCS

Chart 11: Saint Paul's College (Lawrenceville, VA)

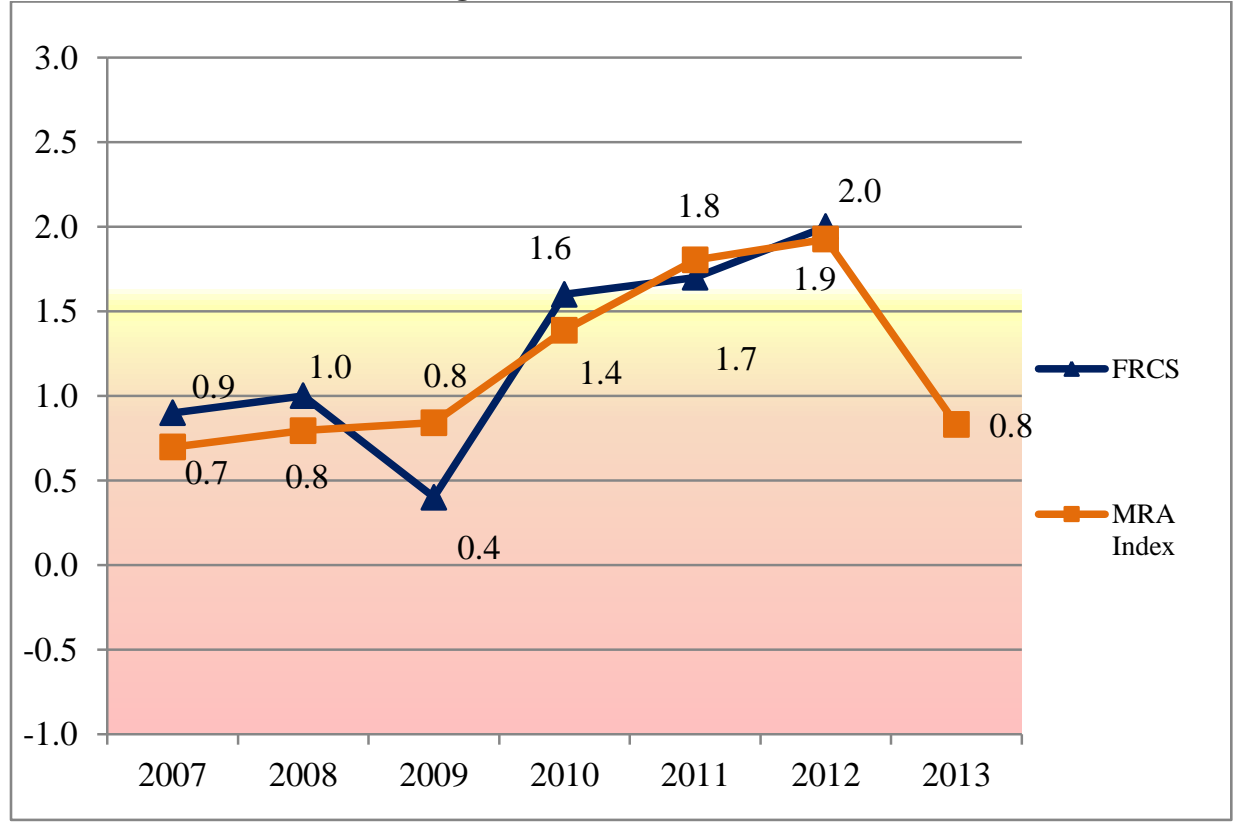

The MRA Index shows generally similar financial health for Saint Paul's College as compared to FRCS 
Chart 12: Ohio Valley University (Vienna, WV)

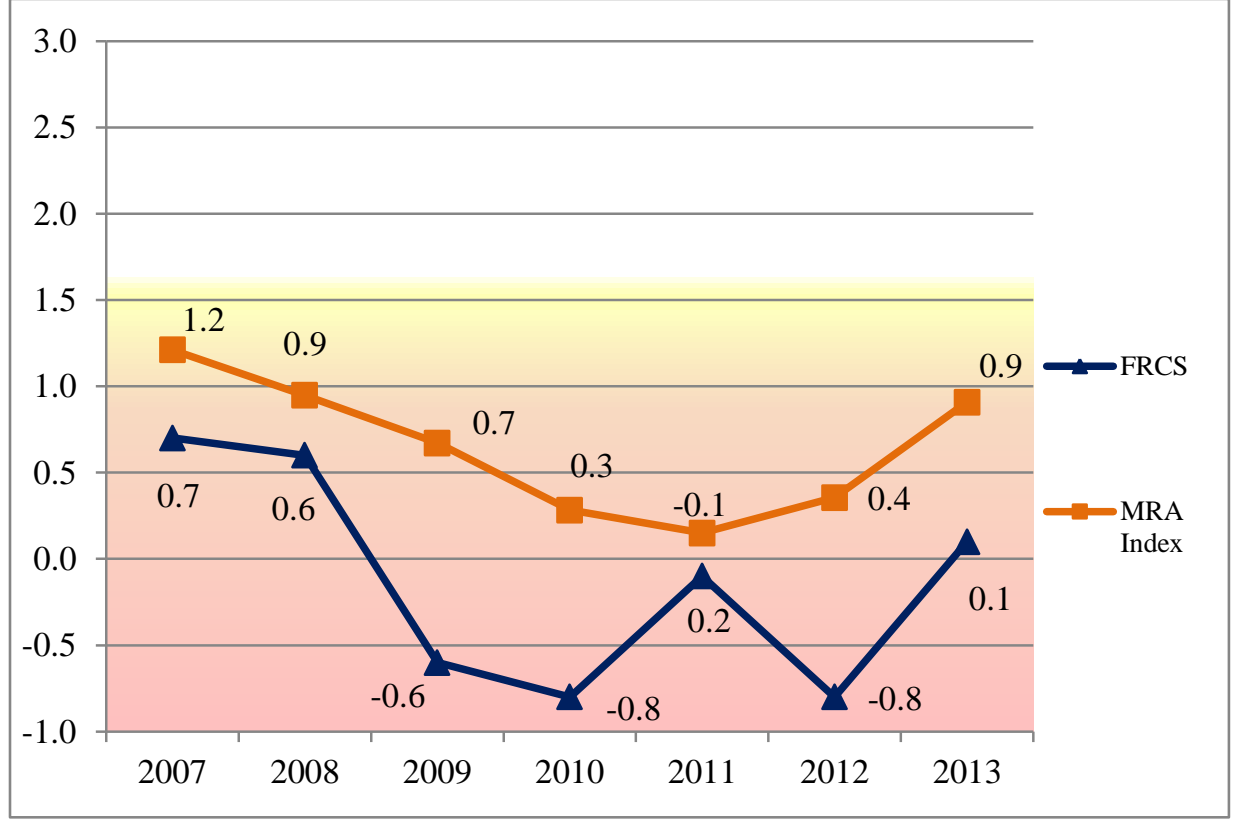

The MRA Index shows consistently better financial health for Ohio Valley University as compared to FRCS

Chart 13: Brevard College (Brevard, NC)

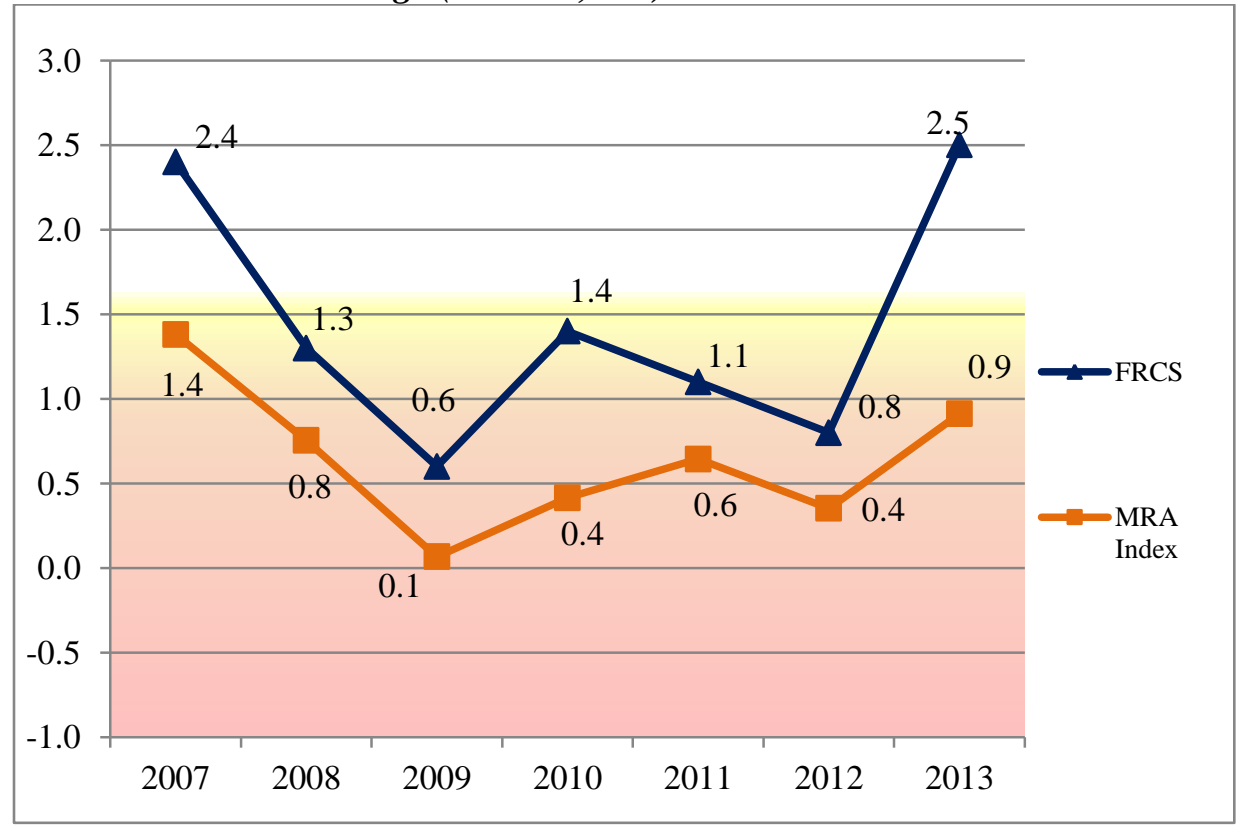

The MRA Index shows consistently lower financial health for Brevard College as compared to FRCS 
Chart 14: Georgetown College (Georgetown, KY)

The MRA Index shows generally lower financial health for Georgetown College as compared to FRCS

Chart 15: MacMurray College (Jacksonville, IL)

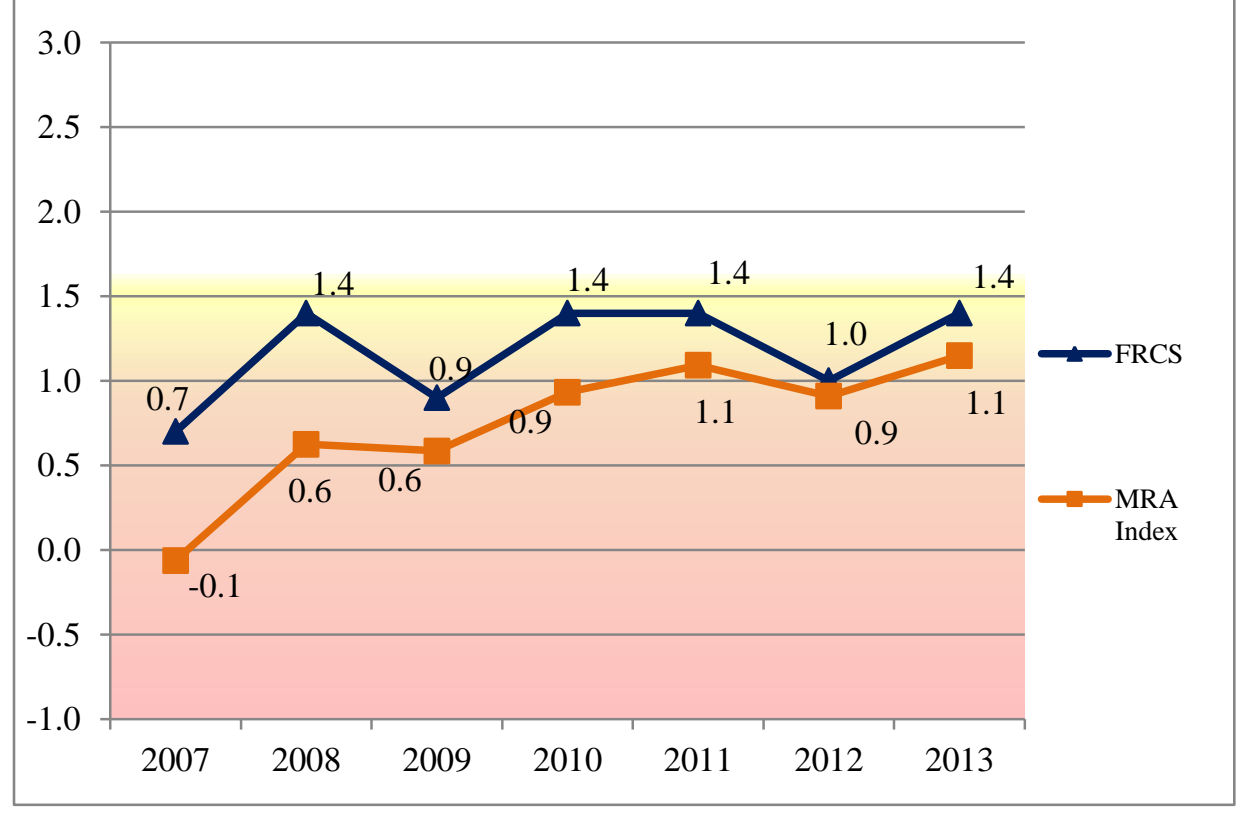

The MRA Index shows slightly lower financial health for MacMurray College as compared to FRCS 
Chart 16: Olivet College (Olivet, MI)

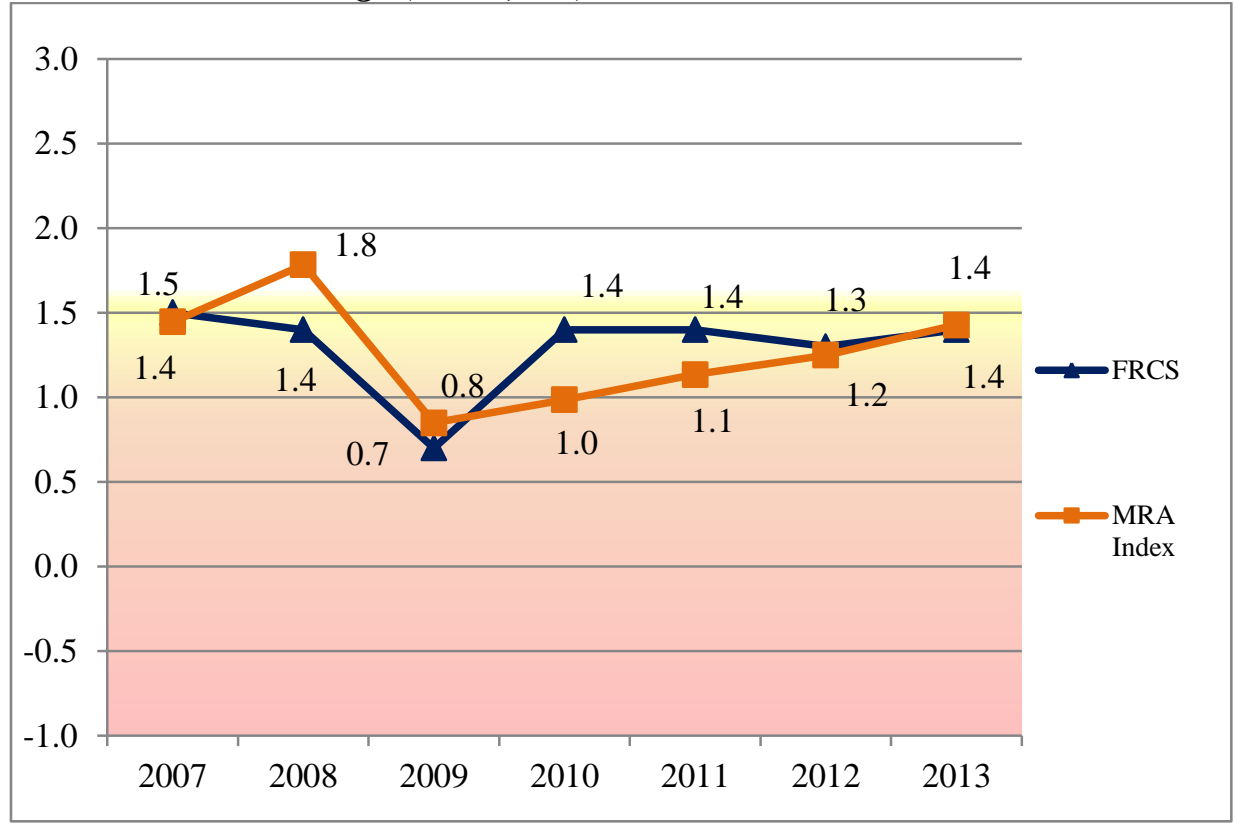

The MRA Index shows generally similar financial health for Olivet College as compared to FRCS

Chart 17: Tennessee Wesleyan College (Athens, TN)

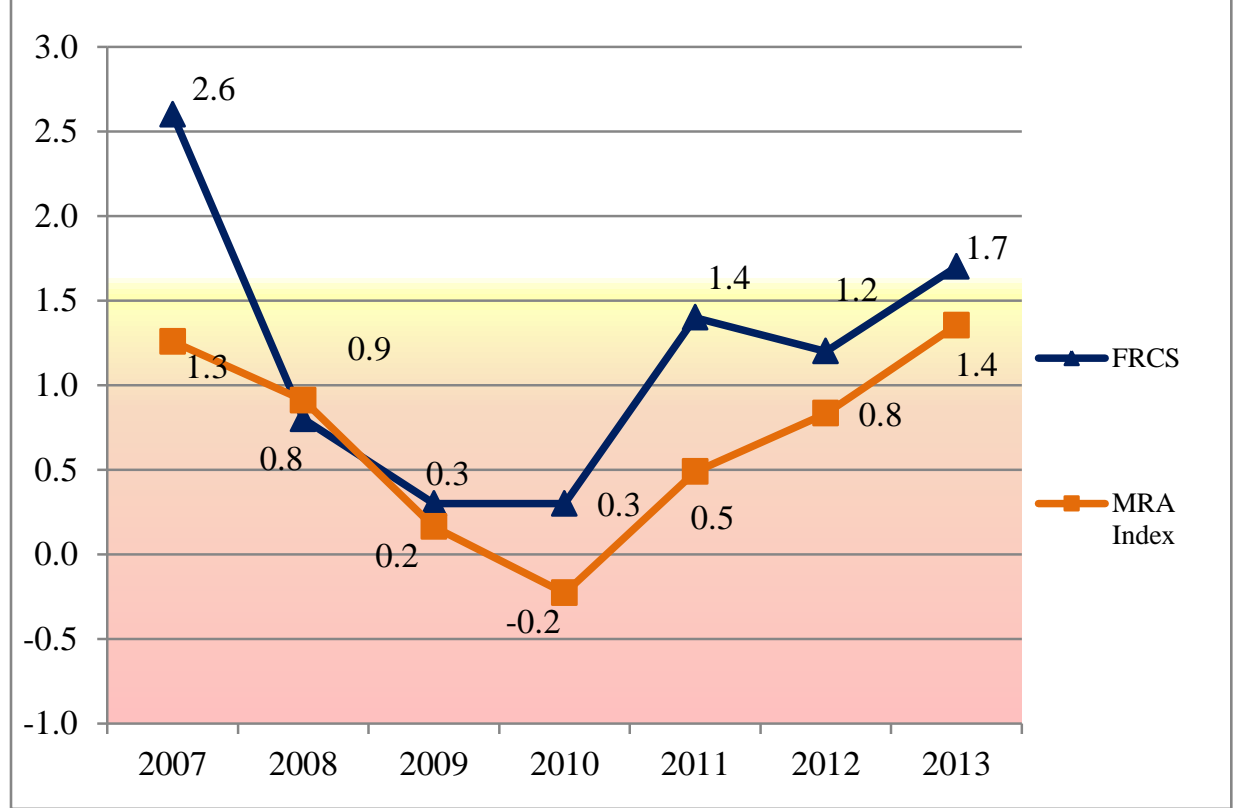

The MRA Index shows consistently lower financial health for Tennessee Wesleyan College as compared to FRCS 
Chart 18: Greensboro College (Greensboro, NC)

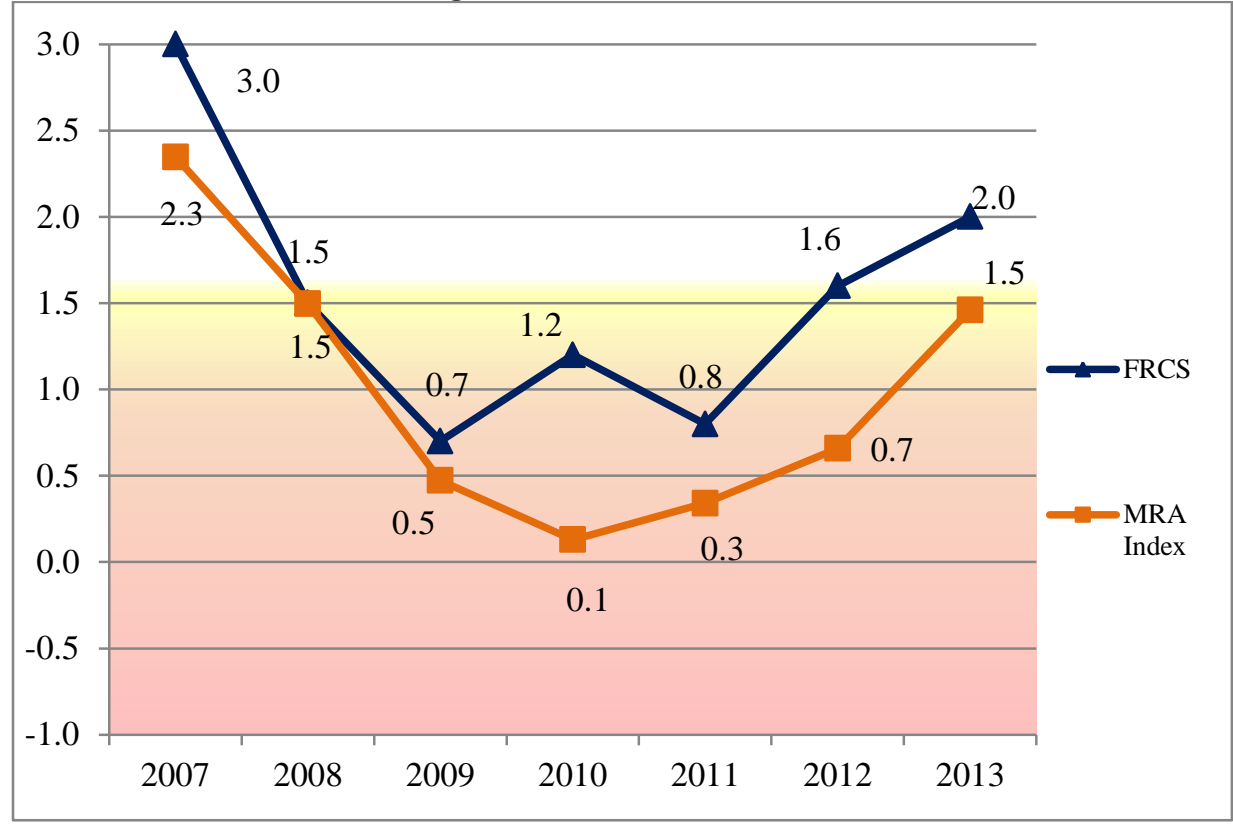

The MRA Index shows consistently lower financial health for Greensboro College as compared to $F R C S$

Chart 19: Wesleyan College (Macon, GA)

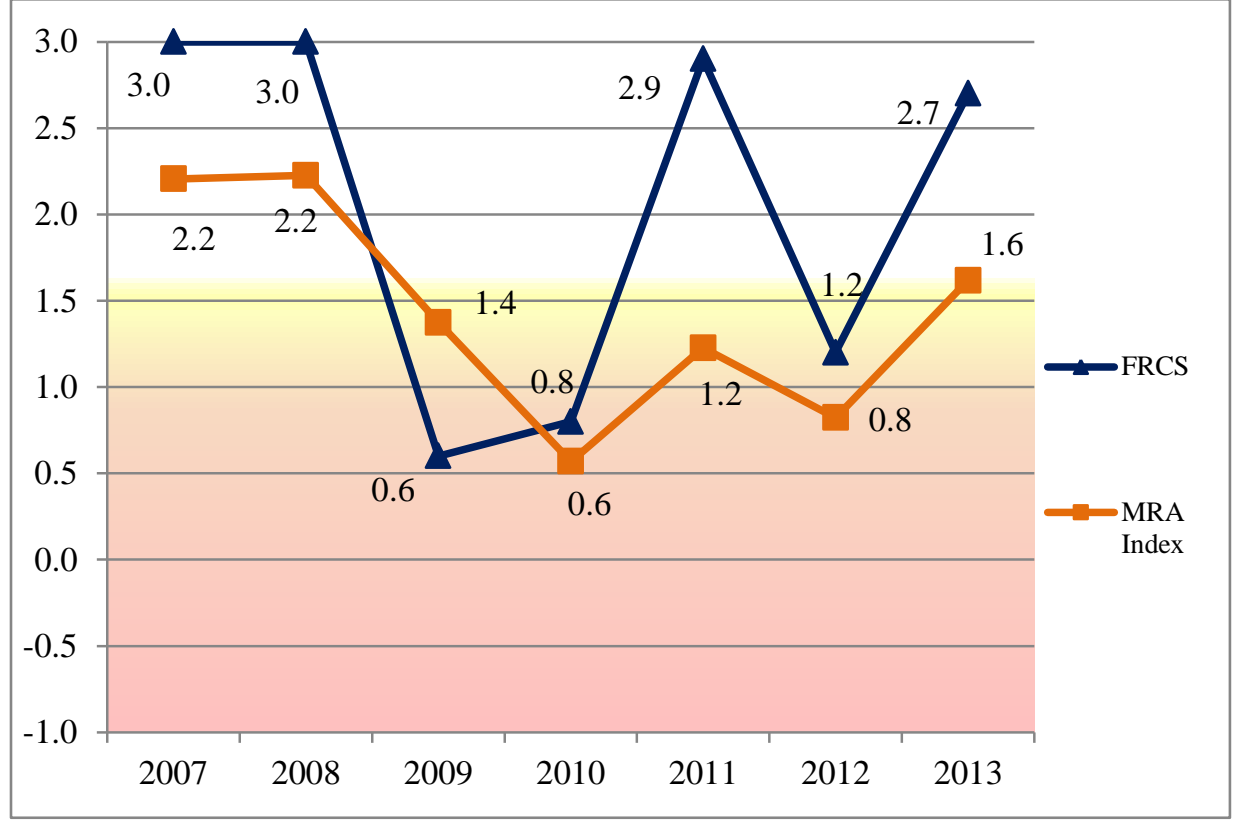

The MRA Index shows generally similar financial health for Wesleyan College as compared to FRCS, though with milder fluctuations 
Chart 20: Vanguard University of Southern California (Costa Mesa, CA)

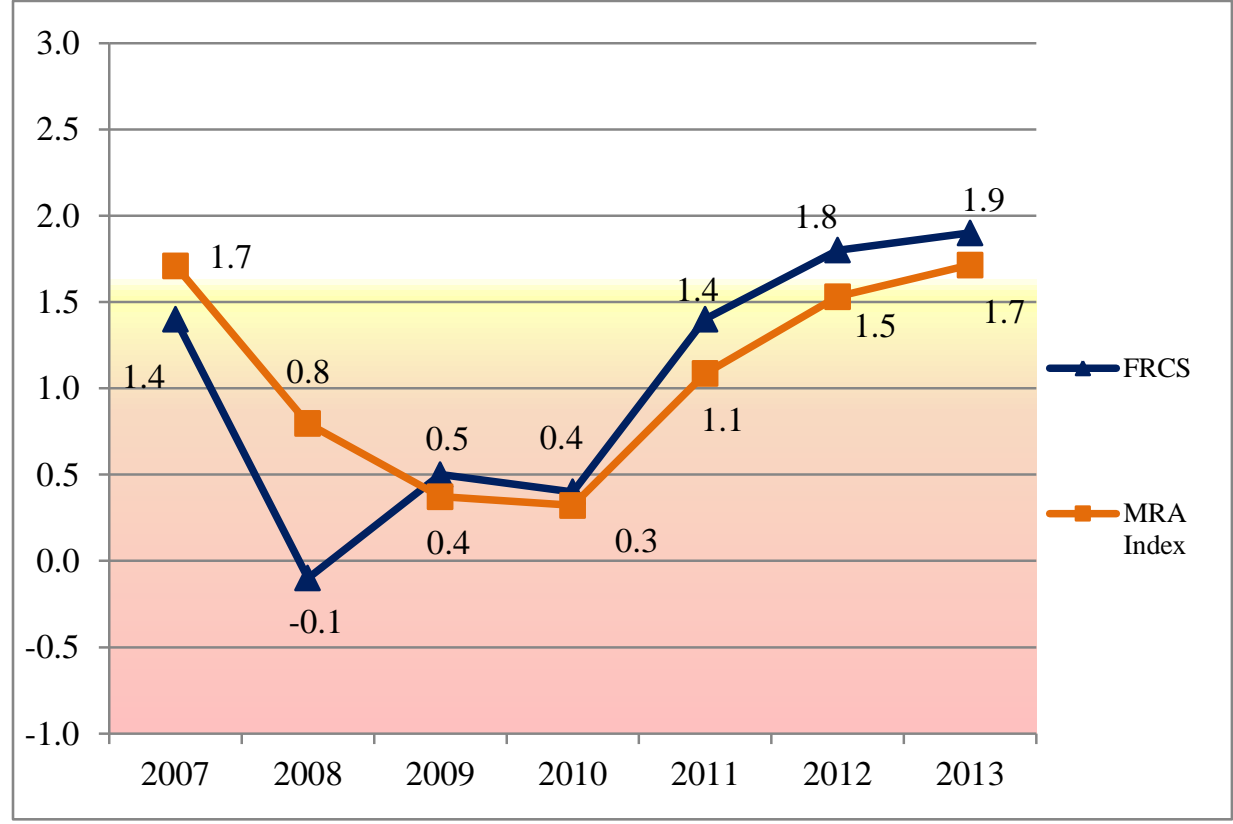

The MRA Index shows generally similar financial health for Vanguard University as compared to FRCS

Chart 21: Caldwell College (Caldwell, $N J)$

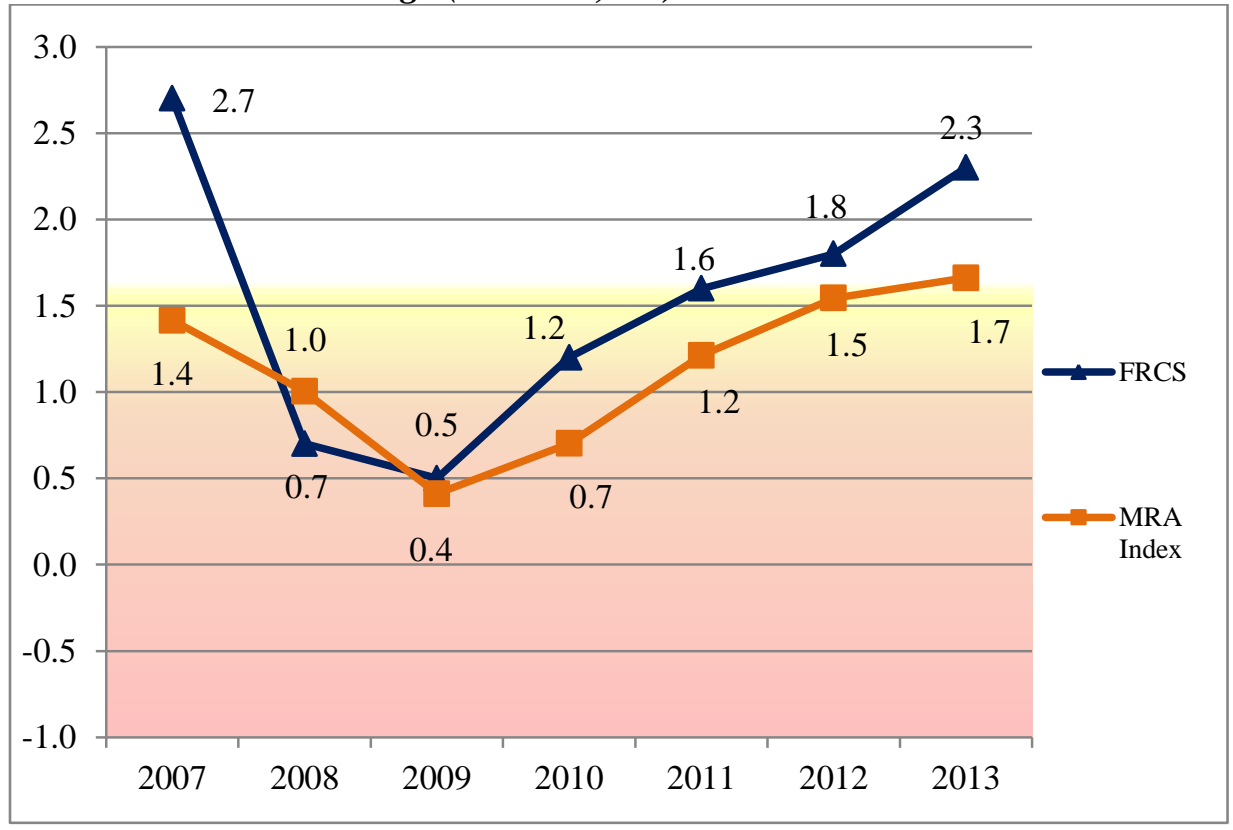

The MRA Index shows generally similar financial health for Caldwell College as compared to FRCS 
Chart 22: Stillman College (Tuscaloosa, AL)

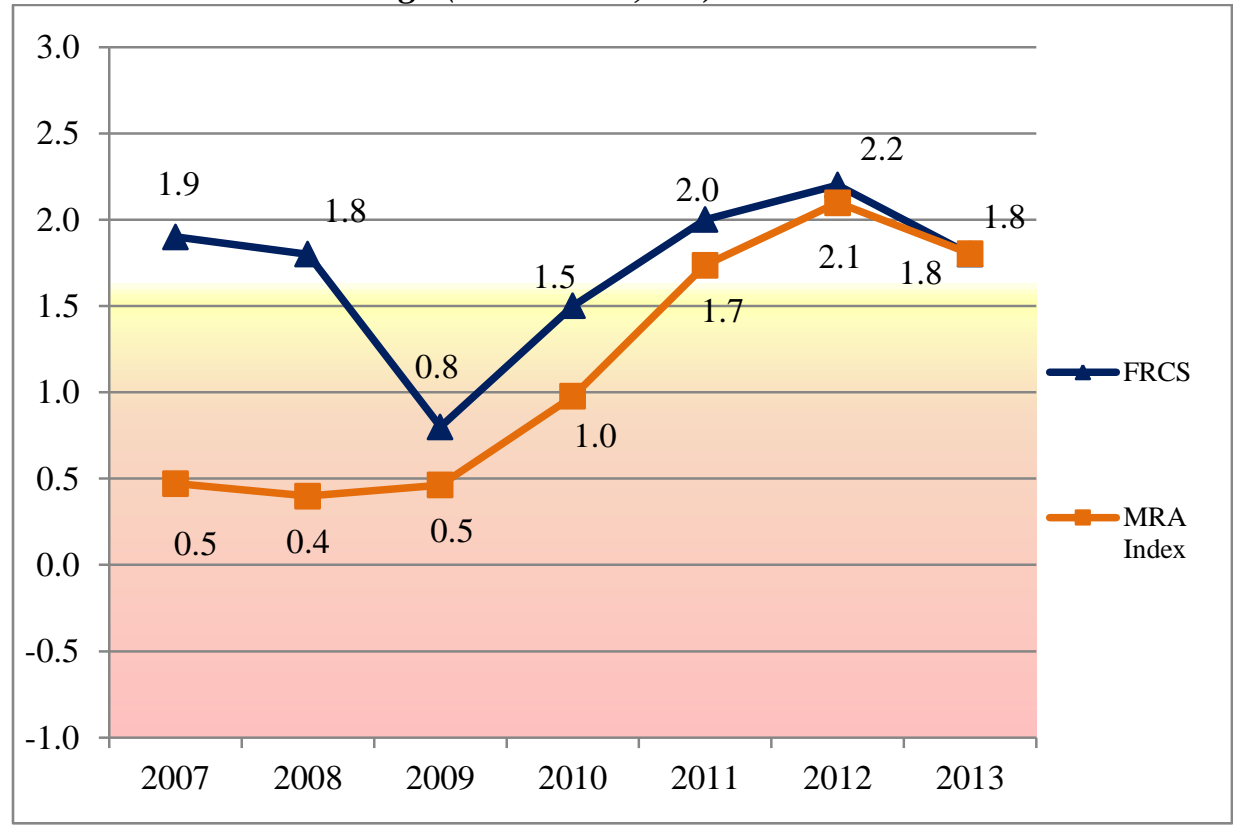

The MRA Index shows consistently lower financial health for Stillman College as compared to FRCS

Chart 23: Eureka College (Eureka, IL)

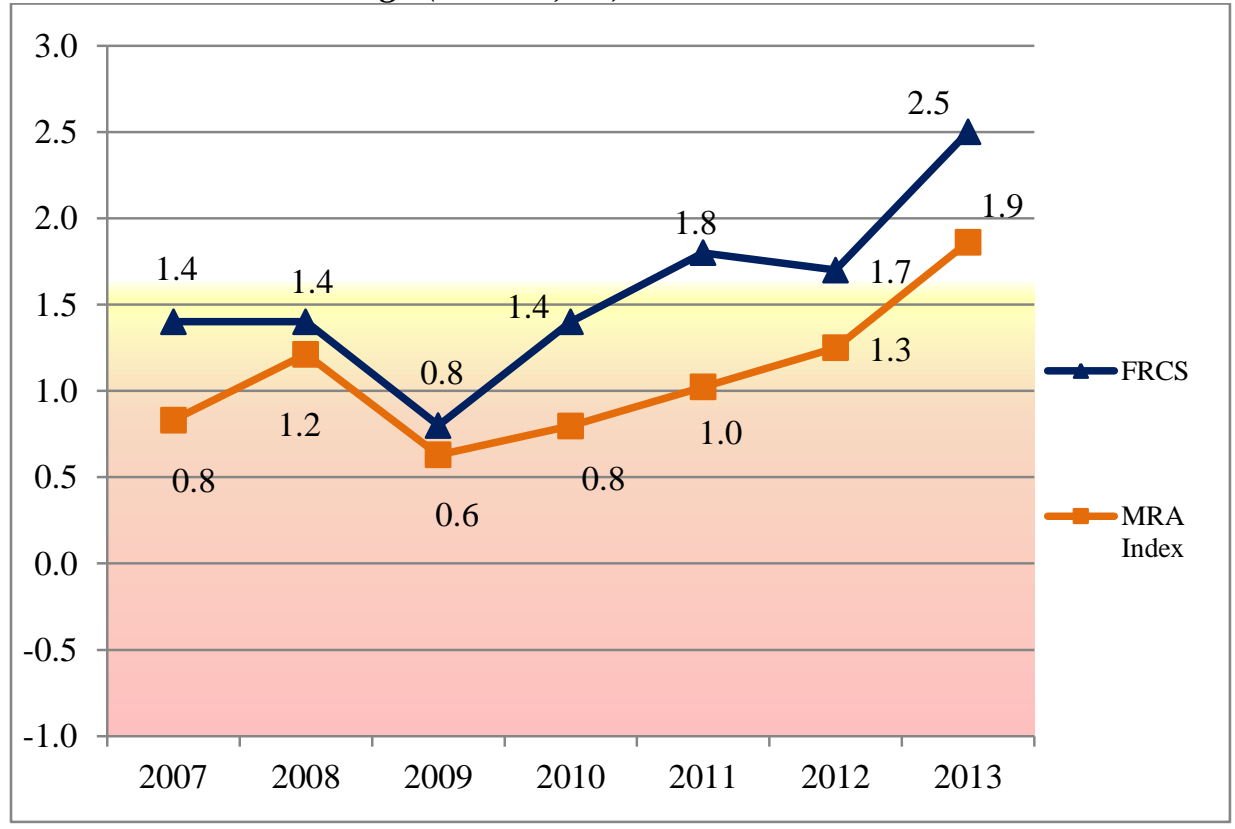

The MRA Index shows consistently lower financial health for Eureka College as compared to FRCS 
Chart 24: Catawba College (Salisbury, NC)

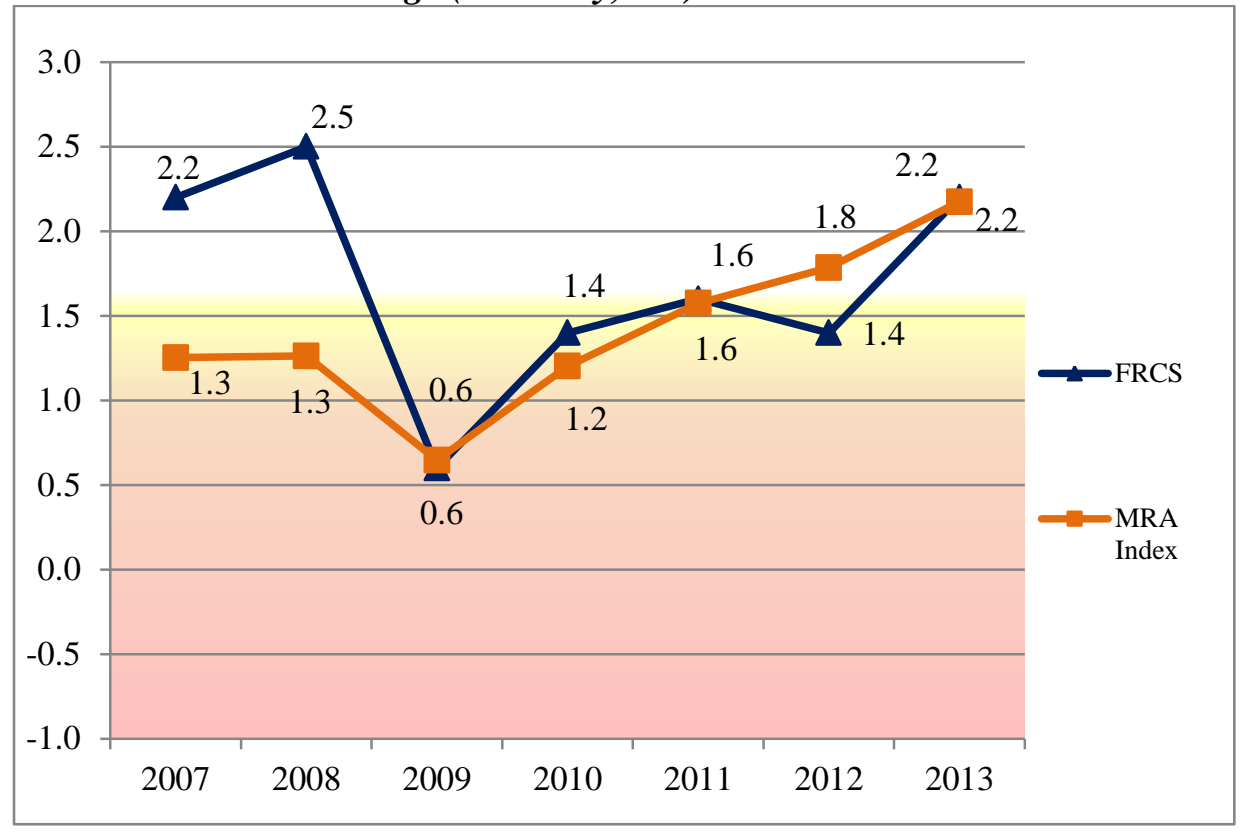

The MRA Index shows generally similar financial health for Catawba College as compared to FRCS

Chart 25: Birmingham Southern College (Birmingham, AL)

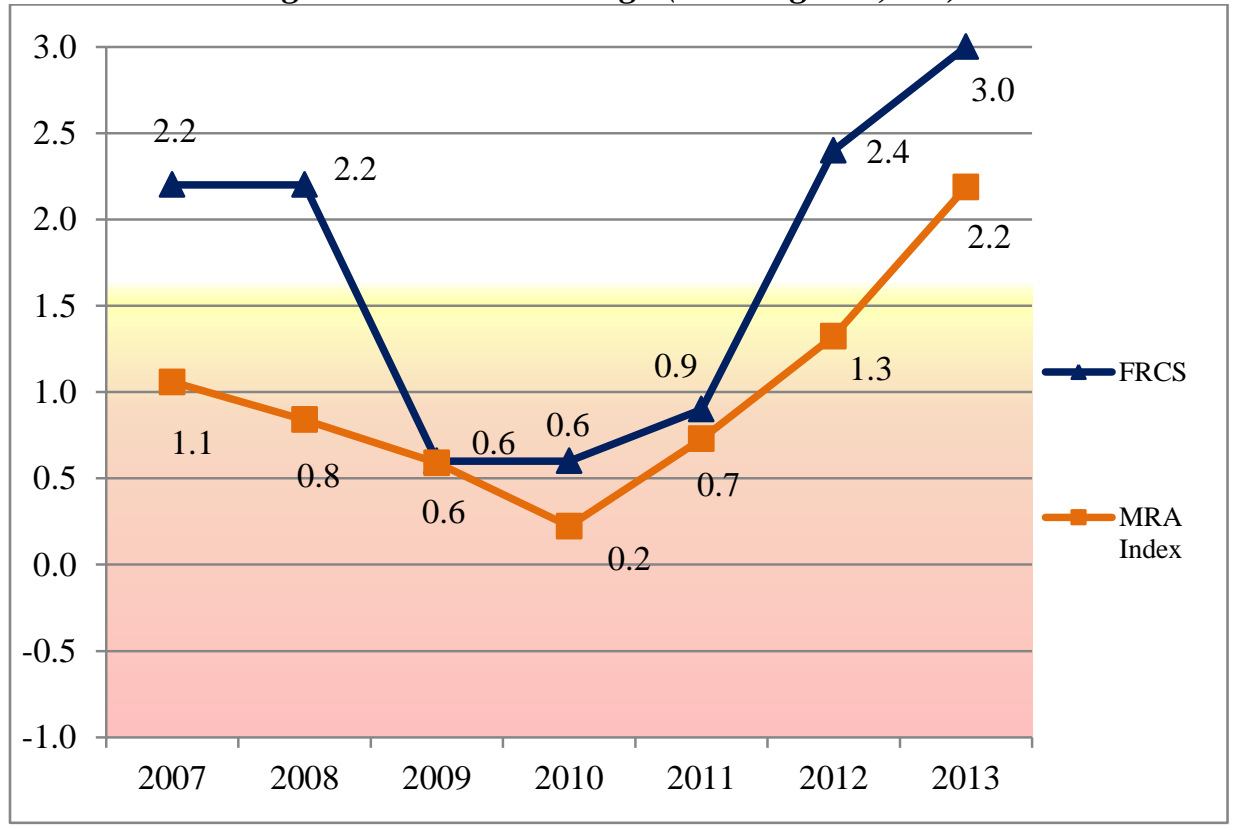

The MRA Index shows consistently lower financial health for Birmingham Southern College as compared to FRCS

As discussed above, the entire sample population shares many of the same concerning characteristics that may have contributed to the demise of the five closed schools, such as small 
scale and high tuition dependence, but according to the MRA Index, several of these open colleges appear to have greater control over employing their financial resources to support their mission.

The extensive financial analysis performed on the population of 25 private bachelor's colleges provides mixed results. Based on analysis of the five closed colleges, the results indicate a tremendous opportunity to improve the effectiveness of analytical tools to predict college closure. The results are less conclusive for the 20 currently-open colleges. 


\section{Chapter 5: Conclusions}

\section{Discussion}

The federal government maintains an enormous investment in all institutions of higher education, whether public, private non-profit, or proprietary. The passage of the Higher Education Act of 1965 introduced a new paradigm of public financing of higher education and transformed the relationship between the federal government and colleges. To carefully steward the $\$ 150$ billion in Title IV funds awarded to students and institutions each year, the Department of Education employs the federal Financial Responsibility Composite Score to identify those colleges at risk of precipitous closure. The success of that stewardship, however, can only be as effective as the metric used, and the FRCS has been criticized in recent years for its flawed methodology and the resulting costs of its Type I and Type II errors.

The purpose of this research was to add to the body of knowledge on financial assessment in higher education by first evaluating the accuracy of the FRCS, and then determining whether an alternate model could better differentiate between colleges at risk of closure and colleges that are financially stable. In part one of the study, FRCS scores on recentlyclosed private, non-profit colleges were analyzed to ascertain the ability of the metric to predict college closures. The results suggest that the FRCS was able to predict only 5 of those 31 recent closures by awarding a failing score in their penultimate year. Despite the small sample size across a period of ten years, this analysis seems to conclusively indicate that the FRCS fails to fulfill its most important role in enabling ED to protect both students and the federal investment against precipitous closure. Conversely, the study examined the rate at which the FRCS metric wrongly subjects financially stable colleges to the increased scrutiny and costs of Heightened Cash Monitoring. Because a serious flaw in the FRCS methodology was exposed during the 
market correction of 2008-2009, hundreds of institutions were placed on HCM for the first time. While not all of these colleges and universities should be definitively classified as financially stable without additional analysis, the sheer scale supports the conclusion that the FRCS is not fully capable of differentiating between colleges at risk of closure and colleges that are financially stable.

To improve the practice of financial assessment in higher education, this study has proposed an alternate model, the Modified Risk Assessment (MRA) Index. Building upon research and practice in both ratio analysis and non-financial risk indicators - much of which has evolved since the FRCS was first proposed in 1996 - this alternate model is scaled for direct comparison against the FRCS but implements several key modifications: the return on net assets ratio, eight key non-financial risk indicators, and a multi-year formula to better represent the realities of colleges' financial situations.

The MRA Index was then tested in extensive financial analysis of 25 private, non-profit colleges to evaluate its effectiveness against the FRCS across the years 2007 through 2013. Efforts to differentiate between colleges of differing financial health are mixed, in part due to the subjectivity in defining financial stability in colleges that share characteristics that correlate to financial stress. However, the results produced one tremendous opportunity: the MRA Index appears to offer a dramatic improvement over the FRCS in its ability to better predict college closures.

\section{Implications}

The results of this study offer lessons for stakeholders throughout higher education. For the Department of Education, the MRA Index offers an example of a metric that could improve the accuracy of the FRCS in differentiating between colleges at risk of closure and colleges that 
are financially stable. For administrators of small, private colleges, the MRA offers specific components that could be useful in measuring and managing an institution's financial strategy. For administrators and participants in other segments of higher education, there are additional messages that can be generalized from the lessons learned through this research.

\section{Implications for the Department of Education}

Identifying colleges at risk of precipitous closure is the most important function of the

FRCS. It is primarily by that mechanism that the Department of Education stewards the federal investment in Title IV funds to colleges and universities. The MRA Index, when employed to assess the financial health of the small, private colleges that have closed, appears to be more effective in awarding a failing financial score two years before a college is forced to close due to financial exigency. In four of five closed colleges, the MRA produces a significantly lower assessment of financial health in the penultimate year than does the FRCS; in the fifth college, there is no meaningful difference between the two metrics. It therefore stands to reason that the inclusion of additional components of the MRA Index could provide valuable insight into improving the practice of predicting college closure by the Department of Education.

More specifically, the blending of the return on net assets ratio into the MRA formula incorporates the assessment of whether a college effectively employs its assets to support its mission. As Tahey et al. (2010) confirmed, the return on net assets ratio works in concert with the net operating revenues ratio to determine whether a college can both live within its means and generate a positive return on its assets. In using only one of these two complementary ratios, the FRCS captures only a partial view of a college's financial health. The MRA's use of four key financial ratios provides a more complete financial assessment, which could begin to explain why it appears to be more accurate in predicting college closure in this small sample. 
The inclusion of eight key risk indicators builds on the work of Martin and Samels (2009) and Lyken-Segosebe and Shepherd (2013) in identifying characteristics of small, private colleges at risk of closure. For these colleges, certain risk indicators strongly correlate to financial exigency, and so a metric that purports to predict college closure is enhanced by incorporating these indicators into the formula.

The use of the multi-year weighted average offers two potential lessons for ED: a mechanism for compensating for the exposed flaw in the FRCS formula, and insight into the way the FRCS metric is currently used. As discussed, the market correction of 2008-2009 exposed a material flaw in the FRCS formula, double-counting investment losses by including them as operating expenses in addition to reflecting the loss in total assets. While ED should ideally engage in future research to fix the flaw in the formula, the results of the MRA Index seem to suggest that incorporating the smoothing factor of a multi-year formula offers a temporary fix by preventing that error from overshadowing the metric's ability to otherwise assess financial health in years of market decline.

Separately, the smoother lines shown by the MRA in the charts of Chapter 4 are not only a more realistic reflection of long-term financial viability, but also serve as a more meaningful tool for the newest consumers of this information: the general public. Historically, when ED refused to release FRCS results publicly due to risk of "serious competitive injury" to colleges (Stratford, 2015), the wild fluctuations of the FRCS might have been allowable or even preferable in order to provide the most current reflection of financial statements. Currently, public dissemination of the data allows prospective students and families to make decisions about college choice based on potentially misleading information about a college's financial condition at a single point in time. The combination of these two factors - the flaw in the FRCS 
formula with the public usage of the information - increases the risk and the cost of a Type I error to a financially healthy college that is unfairly awarded a failing FRCS score.

\section{Implications for Colleges and Universities}

Beyond the primary purpose of improving the accuracy of the FRCS index, implications for small colleges include enhanced tools of financial and non-financial assessment that finance administrators and trustees can employ toward evaluating their own institution's condition and stability. A general recommendation from the findings of the MRA Index is that different financial assessment metrics can offer meaningfully different views of financial health, and are possibly more accurate when incorporating additional terms chosen from reliable research. More precisely, as stated above, the use of the net return on assets ratio is a vital component of financial assessment because it complements the value of the net operating results ratio to portray a more complete picture of financial health.

Similarly, small college administrators in particular would be wise to familiarize themselves with the important research on risk indicators proposed by Martin and Samels and tested by Lyken-Segosebe and Shepherd. These aspects offer both an early warning system for colleges at risk and an opportunity to measure and manage both financial and non-financial characteristics that appear to play a critical role in determining long-term financial stability.

Beyond the population of small colleges, there are generally-applicable lessons for large, complex universities. For example, whereas all 25 small colleges included in the extensive financial analysis had a high dependence on tuition that large universities are unlikely to share, the inverse correlation between financial stability and reliance on any impermanent source of revenue provides a message to all institutions. For example, a large public university might recognize that it is particularly dependent on state appropriations, a source of revenue that is becoming increasingly unreliable in recent decades (Ehrenberg, 2012). In order to mitigate the 
risk of that particular vulnerability, administrators could invest in strategies to develop a more powerful fundraising function, to secure funded research in particular areas of emphasis and future funding growth, or to closely engage legislators in the mission of the university in order to communicate the importance of state funding.

Also, it is possible for units within complex universities to apply these principles to evaluate their financial health on a small scale. As more universities respond to economic pressures by employing decentralized budget models such as responsibility centered management, there is an increased need for financial leadership of units to become increasingly savvy in managing finances. The concepts identified in the MRA Index - searching for the correct blending of financial ratios, including non-financial indicators, and using a multi-year formula — could prove invaluable to financial administrators at all levels.

\section{Limitations and Recommendations}

It should be stated plainly that while the MRA Index appears at first glance to be an improvement over the existing FRCS, it represents merely a first step toward enhancing the financial assessment of colleges. In addition to the limitations outlined in Chapter 3, limitations inherent in this research analysis include the small and restricted population sample, the flaw in the FRCS metric, and the practical complications of achieving improvements of practice.

\section{Limitations of the Population Sample}

These tests were conducted on a specific population: small, private, non-profit colleges. For-profit and public institutions have different accounting methodology, different profit-sharing mechanisms, and different revenue-funding models, leading the Department of Education to create customized FRCS formulas for each segment. Even among private colleges, the advances proposed by the MRA Index, other than conceptually generalizable learnings outlined above, 
might not apply directly to metrics used by large, complex institutions. On the other hand, while this is certainly a limitation in that it may prevent the MRA Index from directly advancing the financial assessment of complex universities, the lesson therein may be even more profound: in order to improve the accuracy of financial assessment tools, the higher education community should abandon the practice of creating a one-size-fits-all metric, and instead focus on evaluating the characteristics that make each sector unique and uniquely susceptible to financial pressures.

\section{Limitations of the FRCS Formula}

The FRCS formula contains a critical flaw that was exposed in the market decline of 2008-2009. In order to facilitate comparisons with the FRCS and evaluate the effect of three added components, the MRA Index also contains this same flawed formula that double-counts investment losses in market decline. Though the incorporation of a multi-year weighted average appears to temporarily lessen the impact, ED would ideally seek professional guidance from accounting experts on customizing and improving the FRCS formula to remove this flaw completely and permanently.

\section{Limitations on Achieving Improvements in Practice}

As stated above, incorporating non-financial risk indicators into a financial assessment metric could greatly improve the accuracy of predicting college closure. It should be noted, however, that this finding offers meaningful practical implications by appearing to improve predictive accuracy, but also carries with it massive policy implications. Even if proven to be indispensable in assessing financial health and predicting closure, several non-financial risk indicators (e.g. religious affiliation) would undoubtedly prove challenging politically to incorporate into any metric utilized in federal regulation.

Beyond the constitutional complications of specific metrics, it is necessary to consider the political nature of accomplishing policy changes. As Mettler (2014) described, higher 
education associations and for-profit lobbyists exert a great amount of skill and influence to defeat reform efforts that have the potential to threaten the sustainability or profit of their members, and any ED strategy to improve accurate prediction of colleges at risk of precipitous closure could potentially be seen as a threat by advocates and lobbyists. Even if well-intended, efforts by higher education associations to lessen the sensitivity of the assessment metric and hinder its ability to predict college closure even slightly could have massive ramifications, as experienced in the bankruptcy of Corinthian Colleges.

\section{Additional Recommendation for Future Research}

An additional opportunity for future research could make significant contributions toward the understanding of financial assessment in higher education: a supplementary qualitative study of financial administrators in the 25 colleges in this sample. In order to determine whether an alternate metric could better differentiate between colleges at risk of closure and colleges that are financially stable, this study conducted analysis of financial data from the same external perspective of the Department of Education. By using data reported in IPEDS and IRS Forms 990, the comparison of the FRCS and the MRA was objective and consistent across institutions. Through the ex-post facto quasi-experimental design, the results reveal a possible correlation between the additional components incorporated into the MRA Index and improved accuracy in predicting college closure. However, they offer little insight into whether financial administrators of these colleges were aware of the dire condition before declaring financial exigency.

Supplementing the quantitative research of this study with qualitative interviews of the financial administrators of these 25 colleges could expand the understanding of the connection between an objective assessment metric and the decisions made at the institutional level. 
In particular, Mid-Continent University provides an opportunity for a fascinating and informative case study. With FRCS scores consistently at the highest possible level of 3.0 in every year before declaring bankruptcy, Mid-Continent reveals a severe disconnect between both the FRCS and the MRA objective assessment and the reality of the financial distress of the university. A deeper examination of the factors that precipitated bankruptcy could be invaluable in improving the accuracy of the financial assessment and could lead to a lower number of Type II errors in the future.

\section{Summary}

The Higher Education Act of 1965 transformed the relationship between the federal government and higher education, enabling a tremendous financial investment in both public and private colleges. In order to protect the public interest in these institutions and carefully steward the $\$ 150$ billion in Title IV funding, ED attempts to identify colleges at risk of precipitous closure with the aid of the Financial Responsibility Composite Score. The problem of practice is centered in the perceived failure of the FRCS, and this study sought to enhance the tools of financial assessment by incorporating additional components of analysis into the MRA Index. With a metric that more accurately differentiates between colleges at risk of closure and colleges that are financially stable, ED can more effectively protect the public interest in maintaining a wide diversity of higher education institutions, and colleges can more effectively manage their financial health. 


\section{References}

Abourezk, K. (June 30, 2010). Dana College in Blair to Close. Lincoln Journal Star. Retrieved from journalstar.com/news/state-and-regional/nebraska/dana-college-in-blair-toclose/article_d83eb3e0-847b-11df-9040-001cc4c03286

Adler, B. (2007). Inside the Higher Ed Lobby: Welcome to One Dupont Circle, where good education-reform ideas go to die. Washington Monthly, 39(9), 35.

Altman, E. I. (1968). Financial ratios, discriminant analysis and the prediction of corporate bankruptcy. The Journal of Finance, 23(4), 589-609.

Andrew, L. D., Friedman, B. D., \& Virginia Polytechnic Institute and State University, Blacksburg Department of Education. (1976). A study of the causes for the demise of certain small, private, liberal arts colleges in the United States. Retrieved from ERIC database (ED125486)

Benezet, L. T. (1976). College organization and student impact. Perceptions of organization in the residential college. Retrieved from ERIC database (ED125486)

Berger, P. G., Ofek, E., \& Swary, I. (1996). Investor valuation of the abandonment option. Journal of Financial Economics, 42(2), 257-287.

Bliss, J. H. (1923). Financial and operating ratios in management. The Ronald Press Company.

Blumenstyk, G. (July 23, 2012). One-third of colleges are on financially 'unsustainable' path, Bain study finds. The Chronicle of Higher Education. Retrieved from chronicle.com/article/One-Third-of-Colleges-Are-on/133095/ 
Blumenstyk, G. (July 1, 2013). Education department faces renewed criticism over colleges' financial health scores. The Chronicle of Higher Education. Retrieved from chronicle.com/article/Education-Dept-Faces-Renewed/140085/

Bolda, P. J., \& Mack, B. A. (1983). A measurement of financial viability among private colleges. Retrieved from ERIC database (ED231325)

Bowen, H. R., \& Minter, W. J. (1976). Private higher education. Second annual report on financial and educational trends in the private sector of American higher education. Retrieved from ERIC database (ED127844)

Brand, M. (1993). The challenge to change: Reforming higher education. Educational Record, 74(4), 6-11.

Breneman, D. W. (1994). Liberal arts colleges: Thriving, surviving, or endangered? Washington, D.C.: Brookings Institution Press.

Breneman, D. W. (2002). For colleges, this is not just another recession. The Chronicle of Higher Education, 48(40), B7-B9.

Breneman, D. W., Doti, J. L., \& Lapovsky, L. (2001). Financing private colleges and universities: The role of tuition discounting. The Finance of Higher Education: Theory, Research, Policy, and Practice, 461-479.

Brubaker, P. (1979). Financial health indicators for institutions of higher learning: A literature review and synthesis. American Institutes for Research in the Behavioral Sciences. Retrieved from ERIC database (ED279221) 
Chabotar, K. J. (1989). Financial ratio analysis comes to non-profits. The Journal of Higher Education, 188-208.

Chabotar, K. J. (2006). Strategic finance: Planning and budgeting for boards, chief executives, and finance officers Association of Governing Boards of Universities and Colleges.

Chabotar, K. J. (2010). What about the rest of us? Small colleges in financial crisis. Change: The Magazine of Higher Learning, 42(4), 6-13.

Chabotar, K. J. (2011). Will your institution pass the financial-responsibility test? Trusteeship, 19(4), 30-33.

Chabotar, K. J., \& Honan, J. P. (1996, May). New yardsticks to measure financial distress. Forum on Faculty Roles \& Rewards, American Association for Higher Education.

Chen, K. C., \& Church, B. K. (1996). Going concern opinions and the market's reaction to bankruptcy filings. Accounting Review, 117-128.

Chen, K. C., \& Wei, K. J. (1993). Creditors' decisions to waive violations of accounting-based debt covenants. Accounting Review, 218-232.

Christensen, C. M., \& Eyring, H. J. (2011). The innovative university: Changing the DNA of higher education from the inside out. John Wiley \& Sons.

Cole, J. R., \& Warren, C. (2010). The biography of the great American university. Academe, 4345. 
Denneen, J., \& Dretler, T. (July 6, 2012). The financially sustainable university. Boston: Bain \& Company. Retrieved from www.bain.com/publications/articles/financially-sustainableuniversity.aspx

Dickmeyer, N. (1983). Financial conditions of colleges and universities. Retrieved from ERIC database (ED227753)

Dickmeyer, N., \& Hughes, K. S. (1980). Financial self-assessment: A workbook for colleges. Retrieved from ERIC database (ED198753)

DiSalvio, P. (1989). Ratio analysis in higher education: Caveat emptor. Journal of Education Finance, 500-512.

Ehrenberg, R. G. (2012). American higher education in transition. The Journal of Economic Perspectives, 193-216.

Geiger, R. L. (2004). Knowledge and money: Research universities and the paradox of the marketplace. Stanford University Press.

Gladieux, L. E, \& Wolanin, T. R. (1976). Congress and the colleges: The national politics of higher education. Lexington, Mass.: Lexington Books.

Gomberg, I. L., \& Atelsek, F. J. (1981). Trends in financial indicators of colleges and universities. Retrieved from ERIC database (ED201256)

Grice, J. S., \& Ingram, R. W. (2001). Tests of the generalizability of Altman's bankruptcy prediction model. Journal of Business Research, 54(1), 53-61. 
Gu, Z. (2002). Analyzing bankruptcy in the restaurant industry: A multiple discriminant model. International Journal of Hospitality Management, 21(1), 25-42.

Hackett, E. R., \& Carrigan, S. D. (1998). Performance indicators. Education Policy Analysis Archives, 6, 17.

Hammonds, K. H., Jackson, S., DeGeorge, G., \& Morris, K. (1997). The new U: A tough market is reshaping colleges. Business Week, 22, 96.

Harper, W. R. (1900). The prospects of the small college [Google Books version]. University of Chicago Press. Retrieved from books.google.com/books?hl=en\&lr=\&id=2RwBAAAAYAAJ

Harvard Magazine (September-October 2009). Endowment value declines $29.5 \%$ as investment return is negative 27.3\%. Harvard Magazine. Retrieved from harvardmagazine.com/2009/09/sharp-endowment-decline-reported

Holt, C. C. (2004). Forecasting seasonals and trends by exponentially weighted moving averages. International journal of forecasting, 20(1), 5-10.

Higher Education Act of 1965, Public Law 89-329 U.S.C. 468 (January 9, 2014).

Horrigan, J. O. (1968). A short history of financial ratio analysis. The Accounting Review, 43(2), 284-294.

Jaschik, S. (2008). Will more colleges merge? Inside Higher Ed. Retrieved from www.insidehighered.com/news/2008/08/25/mergers 
Jaschik, S. (April 15, 2011). End of the road for Lambuth U. Inside Higher Ed. Retrieved from www.insidehighered.com/news/2011/04/15/lambuth_university_to_end_operations

Jaschik, S. (May 21, 2012), Chester College will close. Inside Higher Ed, Retrieved from www.insidehighered.com/news/2012/05/21/chester-college-will-shut-down

Kempner, D. E., \& Shafer, B. S. (1993). The pilot years: The growth of the NACUBO benchmarking project. Business Officer, 27(6), 21-31.

Lerner, J., Schoar, A., \& Wang, J. (2008). Secrets of the Academy: The Drivers of University Endowment Success. NBER Working Paper No. 14341

Lewin, T. (June 8, 2015), Government to forgive student loans at Corinthian Colleges. New York Times, Retrieved from www.nytimes.com/2015/06/09/education/us-to-forgive-federalloans-of-corinthian-college-students.html

Lewis, D., \& Wasescha, A. (1987). Costs and benefits of assessment in post-secondary education. Annual Meeting of the Association for the Study of Higher Education, San Diego, CA.

Lupton, A. H., Augenblick, J., \& Heyison, J. (1976). A special report: The financial state of higher education. Change: The Magazine of Higher Learning, 8(8), 20-35.

Martin, J. (1994). Merging Colleges for Mutual Growth. A New Strategy for Academic Managers. Baltimore, MD: Johns Hopkins University Press. 
Martin, J., \& Samels, J. E. (2009). Turnaround: Leading stressed colleges and universities to excellence. Baltimore, MD: The Johns Hopkins University Press.

McPherson, M. S., \& Schapiro, M. O. (1999). The future economic challenges for the liberal arts colleges. Daedalus, 47-75.

Mettler, S. (2014). Degrees of inequality: How the politics of higher education sabotaged the American dream. New York: Basic Books.

Minter, R., \& Bowen, H. (1977). Private higher education: Third annual report. Washington, DC: Association of American Colleges.

Moody's Investors Service. (September 25, 2015). Small college closures poised to increase. Retrieved from www.moodys.com/research/Moodys-Small-but-notable-rise-expected-inclosures-mergers-for--PR_335314

Murphy, S. D., \& Eddy, J. (1998). Current issues in higher education: Research and reforms [Google Books version] University Press of America. Retrieved from books.google.com/books?hl=en\&lr=\&id=1 zlKH77GTDYC

National Association of College and University Business Officers (NACUBO) (1998). Title IV financial responsibility standards revised. Retrieved from www.nacubo.org/Business_and_Policy_Areas/Accounting/Advisory_Reports/Advisory_Re port_98-1_Title_IV_Financial_Responsibility_Standards_Revised.html 
National Association of Independent Colleges and Universities (NAICU) (2007). Twelve facts that may surprise you about America's private colleges and universities. Retrieved from www.naicu.edu/docLib/20070327_12Facts2006.pdf

National Association of Independent Colleges and Universities. (2012). Report of the NAICU financial responsibility task force. Retrieved from www.naicu.edu/docLib/20121119_NAICUFinan.Resp.FinalReport.pdf

National Center for Education Statistics. (2015). Digest of Education Statistics, 2013 (NCES 2015-011)

National Commission on the Financing of Postsecondary Education. (1973). Financing postsecondary education in the united states. Washington D.C.: Government Printing Office.

Newman, F., Couturier, L., \& Scurry, J. (2004). Higher education isn't meeting the public's needs. Chronicle of Higher Education, 51(8), Retrieved from chronicle.com/article/HigherEducation-Isnt-Meeting/35297

Paulsen, M. B., \& Smart, J. C. (2001). The finance of higher education: Theory, research, policy, and practice. Algora Publishing.

Peruso, J.,Dominick F. (2011). Fit, fat, or failing? The financial health of private higher education. Juniata Voices, 11, 54-73.

Postsecondary Education Participants System. (2015). Institutions on HCM1 or HCM2 as of 121-2015. (No. 4).U.S. Department of Education. 
Sora, J. (2001). Let's pretend we're a corporation: An introduction to the academic/corporate convergence. Corporate Governance: The International Journal of Business in Society, $1(1), 39-45$.

Stratford, M. (March 26, 2015). U.S. keeps scrutiny of risky colleges secret. Inside Higher Ed. Retrieved from www.insidehighered.com/news/2015/03/26/education-dept-keeps-secretnames-colleges-found-be-risky-students-taxpayers

Tahey, P., Salluzzo, R. E., Prager, F. J., Mezzina, L., \& Cowen, C. J. (2010). Strategic financial analysis for higher education: Identifying, measuring \& reporting financial risks (7th ed.) KPMG, Prager, Sealy \& Co., LLC, and Attain.

Talboys, W. M. (1995). Using Financial Ratios in the Analysis of Four Private Universities in the Southwest US: A Case Study.

Task Force on Federal Regulation of Higher Education. (2015). Recalibrating regulation of colleges and universities: Report of the task force on federal regulation of higher education. Retrieved from www.acenet.edu/news-room/Pages/Task-Force-on-Government-Regulationof-Higher-Education-Main.aspx

Thelin, J. R. (2011). A history of American higher education. Baltimore, MD: The Johns Hopkins University Press.

Thelin, J. R., Sanoff, A. P., Suggs, W., \& Wilcox, L. (2006). Meeting the challenge: America's independent colleges and universities since 1956: Essays Council of Independent Colleges. 
Retrieved from www.cic.edu/News-and-Publications/CIC-Books-andReports/Pages/Browse-CIC-Publications.aspx

Thomas, W. E., \& Thomas, W. E. (1973). Readings in cost accounting, budgeting and control South-Western Publishing Company.

Tinsley, A. (2007). Academic revitalization: Fulfilling the turnaround promise. Academic Turnarounds: Restoring Vitality to Challenged American Colleges and Universities, "ed. T. MacTaggart. Westport, CT: ACE/Praeger.

Townsley, M. K. (2002). The small college guide to financial health: Beating the odds. Retrieved from ERIC database (ED469329)

Townsley, M. K. (2009). Small college guide to financial health: Weathering turbulent times. Washington, D.C.: National Association of College and University Business Officers.

U.S. Department of Education. (1997). Student assistance general provisions; final rule. 34 CFR, Part 668

U.S. Department of Education. (2015). Office of Federal Student Aid: About us. Retrieved from studentaid.ed.gov/sa/about

University Herald (October 11, 2014). Mid-Continent University files for bankruptcy protection. University Herald. Retrieved from www.universityherald.com/articles/12044/20141011/mid-continent-university-bankruptcyprotection-united-states-court-financial.htm 
Van Der Werf, M. (2002). Recession and reality set in at private colleges. Chronicle of Higher Education, 48(25) Retrieved from chronicle.com/article/RecessionReality-Set-In/15403

Wall, A. (1919). Study of credit barometrics. Federal Reserve Bulletin, 5, 229-243.

Warfield, T. D., Weygandt, J. J., \& Kieso, D. E. (2008). Intermediate accounting: Principles and analysis John Wiley \& Sons.

Weisbrod, B. A. (2000). To profit or not to profit: The commercial transformation of the nonprofit sector. Cambridge University Press.

Weisbrod, B. Allen, Ballou, J. P., \& Asch, E. Diane. (2008). Mission and money: understanding the university. Cambridge: Cambridge University Press.

Zumeta, W. M., Breneman, D. W., Callan, P. M. \& Finney, J. E. (2012). Financing American higher education in the era of globalization. Cambridge, Mass.: Harvard Education Press. 


\section{Appendix A: Definitions and Terms}

- Accuracy - this research utilizes an $80 \%$ acceptability threshold in evaluating the accuracy of the FRCS metric, relying on a definition of accuracy adopted from the arenas of business operations and financial forecasting: degree of fit between the predictions and the actual data; degree of the closeness to actual value by which an instrument measures or senses the value of a variable being measured or sensed. (Business Dictionary)

- Composite Score - In the Department of Education's financial responsibility standards, the composite score combines three financial ratios which are weighted and assigned strength factors to yield a single measure of a school's overall financial health. (See Appendix B: Financial Responsibility Standards)

- Endowment - An investment fund set up by an institution to provide future financial support. The use of the assets of the fund may be permanently restricted, temporarily restricted, or unrestricted. Endowment funds generally are established by donor-restricted gifts and bequests to provide (a) a permanent endowment, which is to provide a permanent source of income, or a (b) term endowment, which is to provide income for a specified period. Typically, the original gift amount must be maintained in perpetuity (for the perpetual support of the entity) while a portion of earnings or appreciation are withdrawn to support ongoing operations or other specified purposes. Endowment funds are unique to nonprofit organizations. (NAICU, 2012)

- Equity Ratio - one of the ratios used to compute the Department of Education's financial responsibility composite score, intended to measure an institution's capital resources, ability to borrow, and financial viability. (See Appendix B: Financial Responsibility Standards.)

- Failing Composite Score - A score that is less than 1.0. (See Appendix B: Financial Responsibility Standards)

- Financial Health. Ability of an institution to raise and maintain the ongoing resources necessary to fund and support its mission (Talboys, 1995).

- Financial Ratios - analytical tools that can help quantify the status, sources, and uses of an entity's financial resources. There are many standard ratios used to try to evaluate the overall financial condition of an entity. In the case of the Department of Education's financial responsibility scores, three ratios are calculated, assigned strength factors and weights and combined into a single composite score. (See Appendix D: Department of Education Handbook.) The MRA Index includes a fourth, the Return on Net Assets Ratio.

- Financial Responsibility Standards - Department of Education's financial requirements for institutions that provide or seek to provide federal student aid to their students. (See Appendix B: Financial Responsibility Standards)

- Generally Accepted Accounting Principles (GAAP) - The standards of financial accounting that govern financial statement reporting in the United States. GAAP is not a single accounting rule but rather a comprehensive body of many rules that address various transactions. The Financial Accounting Standards Board (FASB) establishes GAAP for nonprofit and commercial entities (including for-profit educational institutions). The rules and procedures that encompass GAAP are complex, have grown in number over time, and continue to evolve annually. Definitions and terminology within these standards for nonprofit and commercial entities sometimes differ based on 
items that are unique to the specific industry. (NAICU, 2012)

- Heightened Cash Monitoring - Often as a result of a failing or "zoned" FRCS scores, a school placed on Heightened Cash Monitoring (HCM) must make disbursements to eligible students and parents before it may request or receive funds for those disbursements from the Department. (NAICU, 2012)

- Intangible Asset - Non-physical assets held by a company that increase its competitive advantage. Includes goodwill, brands, trademarks, and patents.

- Interest Expense - the annual accrued amount of interest that the company paid to its creditors. A higher interest expense means that the company is paying more to its debtors. In general, a company's capital structure with a heavier debt focus will have higher interest expenses.

- Letter of Credit - Correspondence issued by a bank guaranteeing payment for goods and services; e.g., federal student financial aid received by a school, purchased by the one requesting the letter. An irrevocable letter of credit cannot be cancelled or modified without explicit consent of the affected parties. Letters of credit are in effect only for a specified time period and expire at a pre-determined point. Cost can vary. In the case of federal student financial aid, it is usually based on a percentage of the federal student aid received by the institution and its students. (NAICU, 2012)

- Long-Term Debt - A company's total debt is found on its balance sheet and can be divided into two parts, the current (short-term) portion of all its debt obligations and the long term portion of all its debt obligations. Long-term debt represents all legal obligations more than 12 months in duration.

- Monitoring Requirements - Additional requirements the Department of Education may impose on an institution that does not meet the applicable financial responsibility standards. (NAICU, 2012)

- Net Assets - A measure of the net worth of a nonprofit organization, defined as total assets less total liabilities, which is classified into three mutually exclusive classes according to the existence or absence of donor-imposed restrictions. (See unrestricted, temporarily restricted, and restricted net assets.)

- Net Income Ratio (Net Operating Revenues Ratio) - One of the three ratios used to determine the Department of Education's financial responsibility composite score. It measures an institution's ability to operate within its means for the year. (See Appendix B: Financial Responsibility Standards)

- Land, Building and Equipment, net of depreciation - also known as Net Property, Plant, and Equipment (PPE) - Tangible, long-lived assets used in an organization's mission related activities that have an estimated useful life longer than one year, typically comprised of the land, buildings, and their contents owned by the institution, as well as library books. The carrying value of the PPE is shown net of accumulated depreciation.

- Nonprofit (Not-for-profit) - An organization that uses earned revenue and unearned support (gifts) to achieve its goals or accomplish its mission. While nonprofit organizations are permitted to generate surplus revenues, they must be retained by the organization for its self-preservation, expansion, or plans (rather than distributing them as profit or dividends to owners or shareholders). They have controlling members or boards of directors. Nonprofit colleges and universities are exempt from federal income taxes under Section 501(c)(3) of the Internal Revenue Code. (NAICU, 2012) 
- Passing Composite Score - A score of +1.5 to +3.0 (See Appendix B: Financial Responsibility Standards)

- Post-employment and Retirement Plan Liabilities - Benefits (such as health care and pensions) provided to former or inactive employees, their beneficiaries, and covered dependents, creating a long-term liability on the entity's financial statements.

- Primary Reserve Ratio - One of the three ratios used to determine the Department of Education's financial responsibility composite score. This ratio measures an institution's expendable resources in relation to its overall operating size. The ratio indicates how long an institution can function using expendable resources and/or reserves without relying on additional net assets generated by operations. (See Appendix B: Financial Responsibility Standards)

- Provisional Certification - Certification of an institution to participate in the Department of Education's student aid programs, with restrictions specified in the institution's program participation agreement. It is usually in effect for three years, and is used in a number of circumstances; e.g., when an institution initially applies to participate or when an institution is judged by the Department to be in an administrative or financial condition that might jeopardize its ability to perform its responsibilities. (See Appendix B: Financial Responsibility Standards)

- Reimbursement Payment Method - Method under which an institution must first disburse to students and parents the amount of funds those students and parents are eligible to receive under the Federal Pell Grant, Stafford Loan, and campus-based programs before the institution may seek reimbursement from the Secretary of Education for those disbursements. The institution requests the amount of the actual disbursements from the Secretary, identifies the students for whom reimbursements are sought, and shows that students and parents were eligible for the aid.

- Related Party Receivables - Money owed to an organization from a related party. Related parties are those that have a common control relationship with an organization's management, principal owners, or family members.

- Restricted Net Assets - Net assets with constraints placed on them either externally by creditors, grantors, and contributors, or by law.

- Return on Net Assets Ratio - Measures indicate an institution's flexibility to respond to additional capital or programmatic needs over a specific period of time.

- Temporarily Restricted Net Assets - The part of the net assets of a nonprofit organization that result from donor gifts or investment income on donor restricted endowment funds that are available for future spending. Except for term endowments, net assets within this class are considered to be spendable reserves that support the organization. (NAICU, 2012)

- Total Assets - The sum of all current and long-term assets held by a company. An asset is any item with economic value that is held by a company.

- Total Expenses - Outflows of funds, using up of assets, or incurring liabilities from delivering goods, rendering services, or carrying out activities that constitute an entity's ongoing major or central operations. Expenses result from the decisions of an entity's managers about the activities to be carried out and about how and when particular resources are to be used. Expenses do not include losses, which are decreases in net assets from peripheral or incidental transactions, e.g., endowment losses, losses on the 
value of pension trust funds, losses on the fair value of interest rate swaps. (NAICU, 2012)

- Unrestricted Net Assets - The part of the net assets of a nonprofit organization that is neither permanently nor temporarily restricted by donor-imposed stipulations.

Unrestricted net assets generally result from revenues from providing services; producing and delivering goods; unrestricted contributions; and dividends or interest from investing in income-producing assets, less liabilities.

- Viability Ratio: Measures the availability of expendable net assets to cover debt should the institution need to settle its obligations as of the balance sheet date.

- Zone Alternative ("In the Zone") - Provisions in the financial responsibility standards under which an institution that receives a financial score of 1.0 to 1.4 ("In the Zone") may continue to participate in the Department of Education's student aid programs but with certain restrictions. This is regarded as a failing score, but the institution is considered sufficiently financially responsible to participate with additional oversight. (See Appendix B: Financial Responsibility Standards)

Sources: unless otherwise noted, definitions of basic accounting concepts are derived from ycharts Financial Terminal, retrieved from https://ycharts.com/glossary 
In this chapter, we discuss the financial standards schools must maintain to participate in the Federal Student Aid (FSA) programs, such as the composite score and refund reserve standards, as well as the criteria for evaluating the past performance of the school and persons affiliated with the school.

In order to participate in the FSA programs a school must demonstrate that it is financially responsible. To provide the Department with the information necessary to evaluate a school's financial responsibility, schools are required to submit financial information to the Department every year. A school must provide this financial information in the form of an audited financial statement as part of a combined submission that also includes the school's compliance audit. For-profit schools have six months from the end of the schools' fiscal year to provide the combined submission; other schools have nine months.

What follows is an overview of the financial responsibility standards. Schools should refer to Subpart L of the Student Assistance General Provisions for complete information.

The Department determines whether a school is financially responsible based on the school's ability to:

- $\quad$ provide the services described in its official publications and statements;

- properly administer the FSA programs in which the school participates; and

- meet all of its financial obligations.

The financial responsibility standards can be divided into two categories: (1) general standards, which are the basic standards used to evaluate a school's financial health, and (2) performance and affiliation standards, which are standards used to evaluate a school's past performance and to evaluate individuals affiliated with the school.

\section{CHAPTER 11 HIGHLIGHTS}

I Standards for public schools

Il Standards for proprietary or private nonprofit schools

$\rightarrow$ Composite score

$\rightarrow$ Refund reserve standards

$\rightarrow$ Returning funds in a timely manner

$\rightarrow$ Current in debt payments

- Alternatives to the general standards

$\rightarrow$ Letter of credit

$\rightarrow$ Zone alternative

$\rightarrow$ Provisional certific tion

Il Past performance \& affil tion standards

$\rightarrow$ Past performance of a school

$\rightarrow$ Past performance of persons affil ted with a school

Related information

$\rightarrow$ General Participation Requirements, Chapter 3

$\rightarrow$ Administrative Capability, Chapter 10

Financial responsibility cites Sec. 498(c) of the Higher Education Act 34 CFR 668 Subpart L

\section{School Participation Teams}

For information regarding accounting and compliance issues, a school should contact its School Participation Team (see the "Contacts" listing on the Financial Aid Professional Portal www.fsa4schools.ed.gov 


\section{Use of eZ-AUDIT required}

Since June 16, 2003, schools have been required to submit their compliance audits, audited financial statements, and letters confirming their status as public schools through the Department's eZ-AUDIT Electronic Financial Reporting System. See chapter 12 for more information on required audit submissions.

\section{Change in ownership}

When a change in ownership occurs, the Department applies the standards in 34 CFR 668.15.

\section{GENERAL STANDARDS FOR PUBLIC SCHOOLS}

A public school is financially responsible if its debts and liabilities are backed by the full faith and credit of the state or other government entity. The Department considers a public school to have that backing if the school notifies the Department that it is designated as a public school by the state, local, or municipal government entity, tribal authority, or other government entity that has the legal authority to make that designation. The school must also provide the Department with a letter from an official of the appropriate government entity confirming the school's status as a public school. A letter from a government entity may include a confirmation of public school status for more than one school under that government's purview. The letter is a onetime submission and should be submitted as a separate document.

Public schools also must meet the past performance and affiliation standards discussed below, and must submit financial statements prepared in accordance with generally accepted accounting principles (GAAP) and prepared on the accrual basis.

\section{GENERAL STANDARDS FOR PROPRIETARY OR PRIVATE NONPROFIT SCHOOLS}

A proprietary or private nonprofit school is financially responsible if the Department determines that-

- the school has a composite score of at least 1.5;

- the school has sufficient cash reserves to make the required refunds, including the return of Title IV funds (these requirements are known as the refund reserve standards);

- the school is meeting all of its financial obligations, including making required refunds, including the return of Title IV funds and making repayments to cover Title IV program debts and liabilities; and

- the school is current in its debt payments.

These requirements are discussed in more detail below.

Even if a school meets all of the general requirements, the Department does not consider the school to be financially responsible if-

- in the school's audited financial statement the opinion expressed by the auditor was adverse, qualified, or disclaimed, or the auditor expressed doubt about the continued existence of the school as a going concern (unless the Department determines that a qualified or disclaimed opinion does not have a significant bearing on the school's financial condition), or

- the school violated one of the past performance requirements discussed below. 


\section{Composite score}

The composite score standard combines different measures of fundamental elements of financial health to yield a single measure of a school's overall financial health. This method allows financial strength in one area to make up for financial weakness in another area. In addition, this method provides an equitable measure of the financial health of schools of different sizes.

The composite score methodology takes into account the differences between proprietary schools and private nonprofit schools. The variance takes into account the accounting differences between these sectors of postsecondary schools. However, the basic steps used to arrive at the composite score are the same. These steps are described in the chart on the following pages.

\section{Refund reserve standards}

One of the standards that a school must satisfy, in order to be considered financially responsible, is that it must have sufficient cash reserves to return Title IV funds when a student withdraws. A school is considered to have sufficient cash reserves if it:

- is located in a state that has a tuition recovery fund approved by the Department and the school contributes to that fund; or

- for its two most recently completed fiscal years, the school made all required returns in a timely manner (see Volume 5 , Chapter 2 for more information on returns, including timely payment).

\section{Returning funds in a timely manner}

Unearned funds must be returned no later than 45 days after the date of the school's determination that the student withdrew. ED considers the school to have returned funds, depending upon the method it uses to return them. Specifically, the regulations provide that a school has returned funds when it has:

- deposited or transferred the funds into the bank account it maintains for federal funds (see sidebar) no later than 45 days after the date it determines that the student withdrew;

- initiated an electronic funds transfer (EFT) no later than 45 days after the date it determines that the student withdrew;

- initiated an electronic transaction, no later than 45 days after the date it determines that the student withdrew, that informs an FFEL lender to adjust the borrower's loan account for the amount returned; or

- issued a check no later than 45 days (as supported by the school's records) after the date it determines that the student withdrew.

If a check is used to return unearned funds, the Department requires that the check be endorsed by the bank used by the FFEL lender or ED no later than 60 days after the school's determination that a student withdrew in order to be considered a timely return.
Additional information on composite scores

For complete information on the calculation of the composite score, schools should refer to Appendices A and B of Subpart L in the General Provisions regulations.

The Department issued guidance on the treatment of long-term and other debt in calculating these ratios in DCL-GEN-01-02. That guidance was updated in DCL GEN-03-08.

Treatment of long-term debt cite DCL GEN 03-08, July 2003

34 CFR 668, Subpart L, Appendices A \& B

Ratios cite

34 CFR 668.171(b)(3)

Tuition Recovery Funds

When a state submits a tuition recovery fund for approval by the Department, the

Department will consider the extent to which the recovery fund:

- provides returns to both in-state and out-ofstate students;

- complies with FSA requirements for the order of return of funds to sources of assistance; and - is replenished if any claims arise that deplete the fund.

Refund reserve standard cite 34 CFR 668.173

Returning funds cite 34 CFR 668.172(c).

For withdrawn students, returns funds in a timely manner cite 34 CFR 668.22 


\section{Calculating a composite score}

The first step in calculating a school's composite score is to determine the school's primary reserve, equity, and net income ratios by using information from the school's audited financial statement. These ratios take into account the total financial resources of the school. The Primary Reserve Ratio represents a measure of a school's viability and liquidity. The Equity Ratio represents a measure of a school's capital resources and its ability to borrow. The Net Income Ratio represents a measure of a school's profitabili y.

Upon review, some items from a school's audited financial statement may be excluded from the calculation of the ratios. For example, the Department may exclude the effects of questionable accounting treatments, such as excessive capitalization of marketing costs, from the ratio calculations. (See box below for regulatory list of exclusions.)

All long-term debt obtained for the school's purposes may be included for purposes of the Primary Reserve Ratio calculation. However, it is important to note that the overall level of debt obtained for long-term purposes that can be included in the numerator of the Primary Reserve Ratio is limited under the regulations. It cannot exceed the amount of the school's net property, plant, and equipment.

A strength factor score is then calculated for each ratio using equations established by the Department. A strength factor score refle ts a school's relative strength or weakness in a fundamental element of financial health, as measured by the ratios. Specificall, the strength factor scores refle $t$ the extent to which a school has the financial resources to: 1) replace existing technology with newer technology; 2) replace physical capital that wears out over time; 3 ) recruit, retain, and retrain faculty and staff (human capital); and 4) develop new programs.

A weighting percentage is applied to each strength factor score to obtain a weighted score for each ratio. The weighting percentages refle $t$ the relative importance that each fundamental element has for a school in a particular sector (proprietary or private nonprofit)

The sum of the weighted scores equals the school's composite score. Because the weighted scores refle $t$ the strengths and weaknesses represented by the ratios and take into account the importance of those strengths and weaknesses, a strength in the weighted score of one ratio may compensate for a weakness in the weighted score of another ratio.

Once a composite score is calculated, it is measured along a common scale from negative 1.0 to positive 3.0 as indicated in the diagram on the next page. This scale refle ts the probability a school will be able to continue operations and meet its obligations to students and the Department.

\section{Exclusions}

Excluded items. In calculating an institution's ratios, the Secretary-

(1) Generally excludes extraordinary gains or losses, income or losses from discontinued operations, prior period adjustments, the cumulative effect of changes in accounting principles, and the effect of changes in accounting estimates;

(2) May include or exclude the effects of questionable accounting treatments, such as excessive capitalization of marketing costs;

(3) Excludes all unsecured or uncollateralized relatedparty receivables;

(4) Excludes all intangible assets defined as intangible in accordance with generally accepted accounting principles; and
(5) Excludes from the ratio calculations Federal funds provided to an institution by the Secretary under program authorized by the HEA only if-

(i) In the notes to the institution's audited financial statement, or as a separate attestation, the auditor discloses by name and CFDA number, the amount of HEA program funds reported as expenses in the Statement of Activities for the fiscal year covered by that audit or attestation; and

(ii) The institution's composite score, as determined by the Secretary, is less than 1.5 before the reported expenses arising from those HEA funds are excluded from the ratio calculations.

34 CFR 172(c) 


\section{Composite score scale}

1.5 to 3.0 Financially responsible without further oversight.

1.0 to 1.4 In the "Zone." The school is considered financially responsible but additional oversight is required.

-1.0 to .9 Not financially responsible. The school must submit letter of credit of at least $50 \%$ of its FSA funding. The school may be permitted to participate under provisional certific tion with smaller letter of credit-with a minimum of $10 \%$ of its FSA funding.

\section{Example: Calculation of a composite score for a proprietary institution*}

\section{Calculation of Ratios}

$\begin{aligned} & \text { Primary Reserve }=\frac{\text { Adusted equity }}{\text { Total expenses }}=\frac{\$ 760,000}{\$ 9,500,000}=0.080 \\ & \text { Ratio }\end{aligned}=\frac{\text { Modified equity }}{\text { Modified expenses }}=\frac{\$ 810,000}{\$ 2,440,000}=0.332$
$\begin{aligned} & \text { Net Income Ratio } \\ & \text { Ratio }\end{aligned}=\frac{\text { Income before taxes }}{\text { Total revenues }}=\frac{\$ 510,000}{\$ 10,010,000}$

\section{Calculation of Strength Factor Score}

Primary Reserve Strength Factor Score $=20 \times$ Primary Reserve Ratio $20 \times 0.080=1.600$

Equity Strength Factor Score $=$

$6 \times 0.332=1.992$

Net Income Strength Factor Score $=\quad 1+(33.3 \times$ Net Income Ratio $)$ $1+(33.3 \times 0.051)=2.698$

\section{Calculation of Weighted Score}

Primary Reserve Weighted Score $=$ $0.30 \times 1.600=0.480$

Equity Weighted Score $=$ $0.40 \times 1.992=0.797$

Net Income Weighted Score $=$ $0.30 \times 2.698=0.809$ $6 \times$ Equity Ratio

$30 \%$ x Primary Reserve Strength Factor Score

$40 \%$ x Equity Strength Factor Score

$30 \%$ x Net Income Strength Factor Score

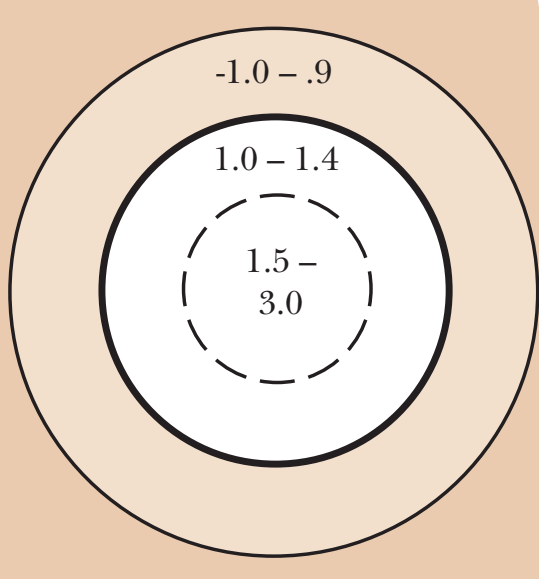

\section{Composite Score}

Sum of All Weighted Scores

$$
0.480+0.797+0.809=2.086 \quad \text { rounded to } 2.1
$$

* The definition of terms used in the ratios and the applicable strength factor algorithms and weighting percentages are found in the Student Assistance General Provisions (regulations) (34 CFR 668) Subpart L, Appendix A for proprietary schools and Appendix B, for private nonprofit schools. 
Deposit to operating account or separate federal bank account

A school that maintains a separate federal bank account must deposit to that account, or transfer from its operating account to its federal account, the amount of unearned program funds, as determined under the Return of Title IV funds regulations. The date the school makes that deposit or transfer is the date used to determine whether the school returned the funds within the 30-day timeframe permitted in the regulations.

Unless the Department requires a school to use a separate account, the school may use its operating account for FSA purposes. In this case, the school must designate that account as its federal bank account, and have an auditable system of records showing that the funds have been allocated properly and returned in a timely manner. If there is no clear audit trail, the Department can require the school to begin maintaining FSA funds in a separate bank account.

34 CFR 668.163(a)

\section{Making new awards with returned funds}

After a school has returned unearned funds to its federal account, provided those funds were originally received from the Department or from an FFEL lender under a process that allows the school to reuse the unearned funds, the school can use the funds to make disbursements to other eligible students.

\section{Compliance thresholds for timely return of funds}

The Department provides for a small margin of error in determining that a school has paid all required refunds and returns on time. The Department considers a school to have paid returns in a timely manner if-

- there is less than a $5 \%$ error rate in a sample of returns (composed of students for whom the school was required to return unearned funds) examined in a compliance audit conducted under 34 CFR 668.23, an audit conducted by the Office of the Inspector General (OIG), or a program review conducted by the Department or guaranty agency; or

- there are no more than two late returns in the sample (regardless of the number or percentage of late returns in the sample).

In addition, if the reviewer or auditor finds a material weakness or reportable condition in the school's report on internal controls relating to the return of unearned Title IV program funds, the Department considers the school to have not paid Returns in a timely manner.

\section{Letter of credit required when funds are not returned in timely manner}

Public schools and schools covered by a state tuition recovery fund that has been approved by the Department are not subject to the letter of credit requirements. If any other school exceeds the compliance thresholds in either of its two most recently completed fiscal years, the school must submit an irrevocable letter of credit acceptable and payable to the Department. The letter of credit must be equal to $25 \%$ of the returns the school made or should have made during its most recently completed fiscal year.

A school that is required to submit a letter of credit must do so no later than 30 days after the earlier of the date that:

- the school is required to submit its compliance audit;

- the OIG issues a final audit report;

- the designated department official issues a final program review determination;

- the Department issues a preliminary program review report or draft audit report, or a guaranty agency issues a preliminary report showing that the school did not return unearned funds for more than $10 \%$ of the sampled students; or

- ED sends a written notice to the school requesting the letter of credit that explains why the school has failed to return unearned funds in a timely manner.

If the finding in the preliminary report is that the school did not return unearned funds in a timely manner for $10 \%$ or fewer of the sampled students, a school would generally be required to submit the letter of credit only if the final report shows that the school did 
not return unearned funds in a timely manner for $5 \%$ or more of all students for whom returns were required. If the final report indicates that a letter of credit is required, the school would have to submit it no later than 30 days after the final report is issued.

\section{Exceptions to the letter of credit requirement}

A school is not required to submit a letter of credit of less than $\$ 5,000$. However, to meet the reserve requirement, such a school would need to demonstrate that it has available at all times cash reserves of at least $\$ 5,000$ to make required returns.

In addition, a school may delay submitting a letter of credit while it asks for reconsideration of a finding that it failed to return unearned Title IV program funds in a timely manner. A school may request that the Department reconsider its finding if the school submits documents showing that:

- $\quad$ the unearned Title IV program funds were not returned in a timely manner solely because of exceptional circumstances beyond the school's control and that the school would not have exceeded the applicable threshold had it not been for the exceptional circumstances; or

- $\quad$ it did not fail to make timely returns.

A school that submits an appeal, together with all required supporting documents by the date the letter of credit would be due is not required to submit a letter of credit unless the Department notifies the school that its request has been denied.

\section{Current in debt payments}

A school is not current in its debt payments if

- it is in violation of any existing loan agreement at its fiscal year end, as disclosed in a note to its audited financial statements or audit opinion; or

- fails to make a payment in accordance with existing debt obligations for more than 120 days, and at least one creditor has filed suit to recover funds under those obligations.
Address for Letters of Credit

Letters of credit are submitted to:

Director

Performance Improvement \& Procedures, U.S. Department of Education

Federal Student Aid

830 First Street, NE,

Washington, DC 20002-8019 


\section{Alternative standards and requirements cite}

34 CFR 668.175

\section{Information to be provided under} zone alternative

The school must provide timely information regarding any of the following oversight and financial events:

- Any adverse action, including a probation or similar action, taken against the institution by its accrediting agency;

- Any event that causes the institution, or related entity as defined in the Statement of Financial Accounting Standards (SFAS)

57 , to realize any liability that was noted as a contingent liability in the institution's or related entity's most recent audited financial statement;

- Any violation by the institution of any loan agreement;

- Any failure of the institution to make a payment in accordance with its debt obligations that results in a creditor filing suit to recover funds under those obligations;

- Any withdrawal of owner's equity from the institution by any means, including by declaring a dividend; or

- Any extraordinary losses, as defined in accordance with Accounting Principles Board (APB) Opinion No. 30.

The school may also be required to: - submit its financial statement and compliance audits earlier than the time specified under $\$ 668.23(\mathrm{a})(4)$; and - provide information about its current operations and future plans.

Cite: 34 CFR 668.175(d)(2)

\section{ALTERNATIVES TO THE GENERAL STANDARDS}

If a school does not meet the general standards for financial responsibility, the Department may still consider the school to be financially responsible or may allow the school to participate under provisional certification if the school qualifies for an alternative standard.

If the Department determines that a school that does not meet one or more of the general standards and does not qualify for an alternative, the Department may initiate a limitation, suspension, or termination action against the school (see Chapter 12 for more information).

\section{Letter of credit alternative for new school}

A new school (a school that seeks to participate in the FSA programs for the first time) that does not meet the composite score standard (i.e., has a composite score of less than 1.5) but meets all other standards may demonstrate financial responsibility by submitting an irrevocable letter of credit to the Department. The letter of credit must be acceptable and payable to the Department and equal to at least $50 \%$ of the FSA program funds that the Department determines that the school will receive during its initial year of participation.

\section{Letter of credit alternative for participating school}

A participating proprietary or private nonprofit school that fails to meet one or more of the general standards or is not financially responsible because it has an adverse audit opinion may demonstrate financial responsibility by submitting an irrevocable letter of credit to the Department. The letter of credit must be acceptable and payable to the Department and equal to at least $50 \%$ of the FSA program funds that the school has received during its most recently completed fiscal year. The school is then considered to be financially responsible.

\section{Zone alternative}

A participating school that fails to meet the composite score standard (i.e., has a composite score of less than 1.5) but meets all other standards may demonstrate financial responsibility for up to three consecutive fiscal years if the Department determines that the school's composite score is equal to 1.0 to 1.4 for each of those years and the school meets specific monitoring requirements.

This alternative gives a school the opportunity to improve its financial condition over time without requiring the school to post a letter of credit or participate under provisional certification. Under the zone alternative, a school's operations, including its administration of the FSA programs, are monitored more closely. If a school does not score at least 1.0 in one of the three subsequent fiscal years or does not improve its financial condition to attain a composite score of at least 1.5 by the end of the three-year period, the school must satisfy another alternative standard to continue participating. In addition, if a school fails to comply with the information reporting or payment method requirements, the Department may determine that the school no longer qualifies under this alternative. 
Under the zone alternative, a school-

- must request and receive funds under the cash monitoring or reimbursement payment methods, as specified by the Department (see Volume 4, Chapter 3);

- must provide timely information regarding certain oversight and financial events (see sidebar);

- may be required to submit its financial statement and compliance audit earlier than normally required (see Chapter 12 for more information on audit submission deadlines); and

- may be required to provide information about its current operations and future plans.

The school must also require its auditor to express an opinion, as part of the school's compliance audit, on the school's compliance with the requirements of the zone alternative, including the school's administration of the payment method under which the school received and disbursed FSA program funds.

\section{Provisional certification for school not meeting standards}

If a participating proprietary or private nonprofit school fails to meet one or more of the general standards or is not financially responsible because it has an unacceptable audit opinion, the Department may permit the school to participate under provisional certification for up to three years.

The Department may permit a school that is not financially responsible to participate under provisional certification if the school is not financially responsible because it:

- does not satisfy the general standards;

- has an unacceptable audit opinion; or

- has a past performance problem that has been resolved.

If the Department permits a school to participate under provisional certification, the Department will require the school:

- to submit to the Department a letter of credit, payable and acceptable to the Department, for a percentage of the FSA program funds received by the school during its most recent fiscal year. (This percentage must be at least $10 \%$ and could be as great at $100 \%$.)

- to demonstrate that it has met all of its financial obligations and was current on its debt payments for its two most recent fiscal years.

Moreover, the school must comply with the requirement under the zone alternative that it provide timely information regarding certain oversight and financial events. Finally, a school that is required to post a letter of credit will be placed on heightened cash monitoring or reimbursement. 
If a school is still not financially responsible at the end of a period of provisional certification, the Department may again permit provisional certification. However, the Department may require the school or persons or entities that exercise substantial control over the school to submit financial guarantees to the Department to satisfy any potential liabilities arising from the school's FSA program participation. The same persons may be required to agree to be jointly and severally liable for any FSA program liabilities.

The Department is not required to offer provisional certification to a school. It is an alternative that the Department may choose to offer in exceptional circumstances.

\section{Provisional certification for school where persons or entities owe liabilities}

If a school is not financially responsible because the persons or entities that exercise substantial control over the school owe an FSA program liability, the Department may permit the school to participate under provisional certification if:

- the persons or entities that owe the liability repay or enter into an agreement with the Department to repay the liability; in lieu of this, the school may assume the liability and repay or enter into an agreement to repay the liability; and

- the school meets all the general standards of financial responsibility (In addition, the school must demonstrate that it has met all of its financial obligations and was current on its debt payments for its two most recent fiscal years.); and

- the school submits to the Department a letter of credit, payable and acceptable to the Department, for an amount determined by the Department. (This amount must be equal to at least $10 \%$ of the FSA program funds received by the school during its most recent fiscal year.)

The school also must comply with the requirements under the zone alternative.

In addition, the Department may require the school or persons or entities that exercise substantial control over the school to submit financial guarantees to the Department to satisfy any potential liabilities arising from the school's FSA program participation. The same persons may be required to agree to be jointly and severally liable for any FSA program liabilities. 


\section{PAST PERFORMANCE AND AFFILIATION STANDARDS}

In addition to meeting the numeric standards of financial responsibility and fulfilling all its financial obligations, a school must demonstrate that it properly administers the FSA programs in which it participates. Past actions of the school or individuals affiliated with the school may reveal mismanagement of FSA program funds, thereby demonstrating that a school is not financially responsible. Therefore, in evaluating the way a school administers the FSA programs, the Department considers the past performance of both the school and individuals affiliated with the school.

\section{Past performance of a school}

A school is not financially responsible if the school:

- in the last five years, has been subject to a limitation, suspension, or termination action or has entered into an agreement to resolve a limitation, suspension, or termination action initiated by the Department or a guaranty agency;

- in either of its two most recent FSA program reviews or audits, has had findings for the current fiscal year or two preceding fiscal years that required repayment of more than $5 \%$ of the FSA program funds received by the school;

- has been cited during the last five years for failing to submit audits as required; or

- has failed to satisfactorily resolve any compliance issues identified in program reviews or audit reports, upheld in a final decision of the Department.

\section{Past performance of persons affiliated with a school}

A school is not financially responsible if any person who exercises substantial control over the school (or any members of the person's family alone or together) owes a liability for an FSA program violation or has ever exercised substantial control over another school (or a third-party servicer) that owes a liability for an FSA program violation, unless that person, family member, school, or servicer demonstrates that the liability is being repaid in accordance with an agreement with the Department.

The Department may consider a school that does not meet this requirement to be financially responsible if the school:

- notifies the Department that the individual repaid to the Department an acceptable portion of the liability, in accordance with the regulations;

- notifies the Department that the liability is currently being repaid in accordance with a written agreement with the Department; or

- demonstrates to the satisfaction of the Department: (1) why the person who exercises substantial control should nevertheless be considered to lack that control, or (2) why the person who exercises substantial control and each member of that person's family does not or did not exercise substantial control over the school or servicer that owes the liability.
Notifying the Department of change of control

A school must report any changes of control under which a person acquires the ability to affect substantially the actions of the school. Such changes in control trigger a review to determine if the school is financially responsible (see Chapter 5).

Fidelity bond coverage for employees

In the past, schools were required to maintain fidelity bond coverage for their employees. This is no longer a federal requirement for schools that participate in the FSA programs. However, by state law some schools are still required to maintain fidelity bond coverage. Even if a school is not required to do so, it may choose to maintain fidelity bond coverage to protect itself when losses occur because of a lack of integrity, on the part of the school's employees or officers. 


\title{
HIGHER EDUCATION ACT
}

\section{Subpart 3-Eligibility and Certification Procedures}

\author{
SEC. 498. [20 U.S.C. 1099c]. ELIGIBILITY AND CERTIFICATION \\ PROCEDURES.
}

(c) FINANCIAL RESPONSIBILITY STANDARDS.-(1) The Secretary shall determine whether an institution has the financial responsibility required by this title on the basis of whether the institution is able-

(A) to provide the services described in its official publications and statements;

(B) to provide the administrative resources necessary to comply with the requirements of this title; and

(C) to meet all of its financial obligations, including (but not limited to) refunds of institutional charges and repayments to the Secretary for liabilities and debts incurred in programs administered by the Secretary.

(2) Notwithstanding paragraph (1), if an institution fails to meet criteria prescribed by the Secretary regarding ratios that demonstrate financial responsibility, then the institution shall provide the Secretary with satisfactory evidence of its financial responsibility in accordance with paragraph (3). Such criteria shall take into account any differences in generally accepted accounting principles, and the financial statements required thereunder, that are applicable to for-profit, public, and nonprofit institutions. The Secretary shall take into account an institution's total financial circumstances in making a determination of its ability to meet the standards herein required.

(3) The Secretary shall determine an institution to be financially responsible, notwithstanding the institution's failure to meet the criteria under paragraphs (1) and (2), if-

(A) such institution submits to the Secretary third-party financial guarantees that the Secretary determines are reasonable, such as performance bonds or letters of credit payable to the Secretary, which third-party financial guarantees shall equal not less than one-half of the annual potential liabilities of such institution to the Secretary for funds under this title, including loan obligations discharged pursuant to section 437, and to students for refunds of institutional charges, including funds under this title;

(B) such institution has its liabilities backed by the full faith and credit of a State, or its equivalent;

(C) such institution establishes to the satisfaction of the Secretary, with the support of a financial statement audited by an independent certified public accountant in accordance with generally accepted auditing standards, that the institution has sufficient resources to ensure against the precipitous closure of the institution, including the ability to meet all of its financial obligations (including refunds of institutional charges and repayments to the Secretary for liabilities and debts incurred in programs administered by the Secretary); or

(D) such institution has met standards of financial responsibility, prescribed by the Secretary by regulation, that indicate a level of financial strength not less than those required in paragraph (2).

(4) If an institution of higher education that provides a 2-year or 4-year program of instruction for which the institution awards an associate or baccalaureate degree fails to meet the criteria imposed by the Secretary pursuant to paragraph (2), the Secretary shall waive that particular requirement for that institution if the institution demonstrates to the satisfaction of the Secretary that-

(A) there is no reasonable doubt as to its continued solvency and ability to deliver quality educational services; 
(B) it is current in its payment of all current liabilities, including student refunds, repayments to the Secretary, payroll, and payment of trade creditors and withholding taxes; and

(C) it has substantial equity in school-occupied facilities, the acquisition of which was the direct cause of its failure to meet the criteria.

(5) The determination as to whether an institution has met the standards of financial responsibility provided for in paragraphs (2) and (3)(C) shall be based on an audited and certified financial statement of the institution. Such audit shall be conducted by a qualified independent organization or person in accordance with standards established by the American Institute of Certified Public Accountants. Such statement shall be submitted to the Secretary at the time such institution is considered for certification or recertification under this section. If the institution is permitted to be certified (provisionally or otherwise) and such audit does not establish compliance with paragraph (2), the Secretary may require that additional audits be submitted.

(6) (A) The Secretary shall establish requirements for the maintenance by an institution of higher education of sufficient cash reserves to ensure repayment of any required refunds.

(B) The Secretary shall provide for a process under which the Secretary shall exempt an institution of higher education from the requirements described in subparagraph (A) if the Secretary determines that the institution-

(i) is located in a State that has a tuition recovery fund that ensures that the institution meets the requirements of subparagraph (A);

(ii) contributes to the fund; and

(iii) otherwise has legal authority to operate within the State. 
\begin{tabular}{l|l}
990 & Return of Organization Exempt From Income Tax
\end{tabular}

Under section 501(c), 527, or 4947 (a)(1) of the Internal Revenue Code (except private foundations)

Department of the Treasury

Internal Revenue Service

- Do not enter social security numbers on this form as it may be made public.

Information about Form 990 and its instructions is at www.irs.gov/form990.

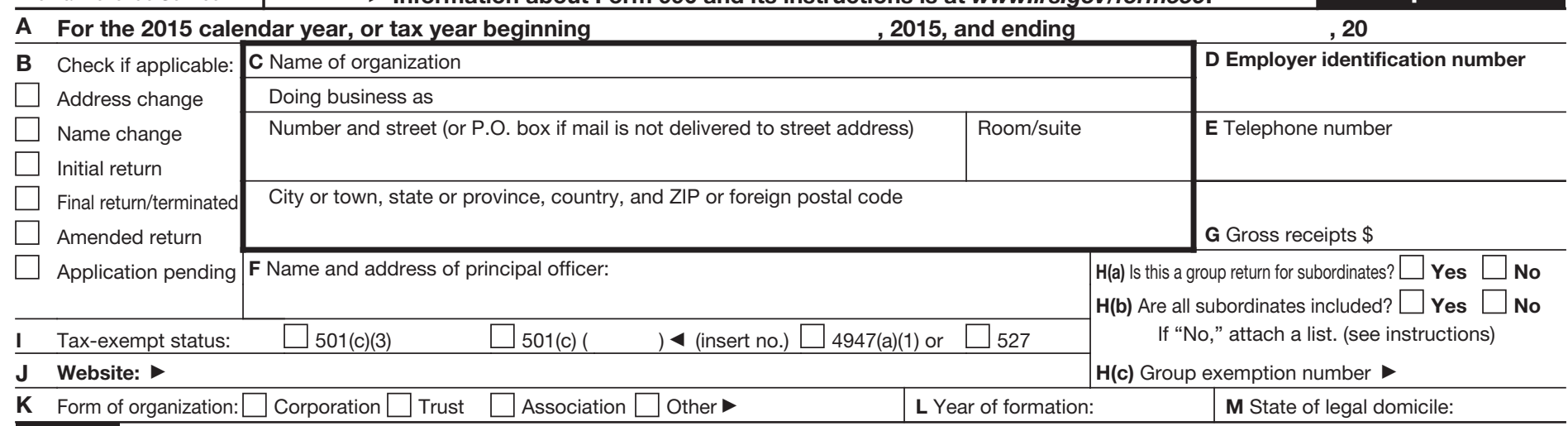

\section{Part I Summary}

1 Briefly describe the organization's mission or most significant activities:

2 Check this box $\square$ if the organization discontinued its operations or disposed of more than $25 \%$ of its net assets

3 Number of voting members of the governing body (Part VI, line 1a).

4 Number of independent voting members of the governing body (Part VI, line 1b)

5 Total number of individuals employed in calendar year 2015 (Part V, line 2a)

6 Total number of volunteers (estimate if necessary)

7a Total unrelated business revenue from Part VIII, column (C), line 12

b Net unrelated business taxable income from Form 990-T, line 34

๑ 8 Contributions and grants (Part VIII, line 1h)

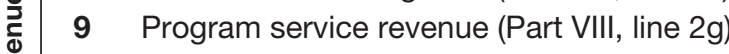

10 Investment income (Part VIII, column (A), lines 3, 4, and 7d)

11 Other revenue (Part VIII, column (A), lines 5, 6d, 8c, 9c, 10c, and 11e)

12 Total revenue-add lines 8 through 11 (must equal Part VIII, column (A), line 12)

13 Grants and similar amounts paid (Part IX, column (A), lines 1-3) .

14 Benefits paid to or for members (Part IX, column (A), line 4)

15 Salaries, other compensation, employee benefits (Part IX, column (A), lines 5-10)

16a Professional fundraising fees (Part IX, column (A), line 11e)

b Total fundraising expenses (Part IX, column (D), line 25)

17 Other expenses (Part IX, column (A), lines 11a-11d, 11f-24e)

18 Total expenses. Add lines 13-17 (must equal Part IX, column (A), line 25)

19 Revenue less expenses. Subtract line 18 from line 12

20 Total assets (Part X, line 16)

21 Total liabilities (Part X, line 26)

22 Net assets or fund balances. Subtract line 21 from line 20

\section{Part II Signature Block}

Under penalties of perjury, I declare that I have examined this return, including accompanying schedules and statements, and to the best of my knowledge and belief, it is true, correct, and complete. Declaration of preparer (other than officer) is based on all information of which preparer has any knowledge.

\begin{tabular}{|c|c|c|c|c|c|c|c|c|c|}
\hline \multirow{2}{*}{$\begin{array}{l}\text { Sign } \\
\text { Here }\end{array}$} & \multicolumn{5}{|l|}{ Signature of officer } & \multicolumn{4}{|c|}{ Date } \\
\hline & \multicolumn{9}{|c|}{ Type or print name and title } \\
\hline \multirow{3}{*}{$\begin{array}{l}\text { Paid } \\
\text { Preparer } \\
\text { Use Only }\end{array}$} & Print/Type preparer's name & Preparer's signature & & \multicolumn{3}{|l|}{ Date } & $\begin{array}{l}\text { Check } \square \text { if } \\
\text { self-employed }\end{array}$ & \multicolumn{2}{|l|}{ PTIN } \\
\hline & \multicolumn{5}{|l|}{ Firm's name } & \multicolumn{4}{|c|}{ Firm's EIN $\triangleright$} \\
\hline & \multicolumn{5}{|l|}{ Firm's address $\downarrow$} & \multicolumn{4}{|c|}{ Phone no. } \\
\hline \multicolumn{3}{|c|}{ May the IRS discuss this return with the preparer shown above? (see instructions) } & . &.$\quad$. & . &.$\quad$. & . . . . . . & $\square$ Yes & No \\
\hline
\end{tabular}




\section{Part III Statement of Program Service Accomplishments}

Check if Schedule O contains a response or note to any line in this Part III

1 Briefly describe the organization's mission:

2 Did the organization undertake any significant program services during the year which were not listed on the prior Form 990 or $990-E Z$ ?

If "Yes," describe these new services on Schedule O.

3 Did the organization cease conducting, or make significant changes in how it conducts, any program services?

If "Yes," describe these changes on Schedule O.

4 Describe the organization's program service accomplishments for each of its three largest program services, as measured by expenses. Section 501(c)(3) and 501(c)(4) organizations are required to report the amount of grants and allocations to others, the total expenses, and revenue, if any, for each program service reported.

$4 a$ (Code: $\quad$ ) (Expenses \$ including grants of \$ _...) (Revenue \$

4b (Code: _ $)$ (Expenses \$ including grants of \$ $\quad$ Revenue \$

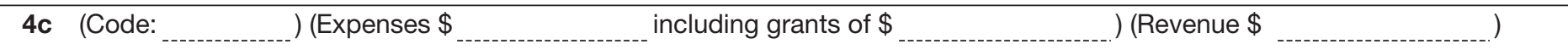

4d Other program services (Describe in Schedule O.) (Expenses \$ including grants of \$

) (Revenue \$ )


1 Is the organization described in section 501(c)(3) or 4947(a)(1) (other than a private foundation)? If "Yes," complete Schedule A.

2 Is the organization required to complete Schedule B, Schedule of Contributors (see instructions)?

3 Did the organization engage in direct or indirect political campaign activities on behalf of or in opposition to candidates for public office? If "Yes," complete Schedule C, Part I .

4 Section $501(\mathrm{c})(3)$ organizations. Did the organization engage in lobbying activities, or have a section $501(\mathrm{~h})$ election in effect during the tax year? If "Yes," complete Schedule C, Part II .

5 Is the organization a section 501(c)(4), 501(c)(5), or 501(c)(6) organization that receives membership dues, assessments, or similar amounts as defined in Revenue Procedure 98-19? If "Yes," complete Schedule C, Part III

6 Did the organization maintain any donor advised funds or any similar funds or accounts for which donors have the right to provide advice on the distribution or investment of amounts in such funds or accounts? If "Yes," complete Schedule D, Part I

7 Did the organization receive or hold a conservation easement, including easements to preserve open space, the environment, historic land areas, or historic structures? If "Yes," complete Schedule D, Part II

8 Did the organization maintain collections of works of art, historical treasures, or other similar assets? If "Yes," complete Schedule D, Part III

9 Did the organization report an amount in Part X, line 21, for escrow or custodial account liability, serve as a custodian for amounts not listed in Part X; or provide credit counseling, debt management, credit repair, or debt negotiation services? If "Yes," complete Schedule D, Part IV .

10 Did the organization, directly or through a related organization, hold assets in temporarily restricted endowments, permanent endowments, or quasi-endowments? If "Yes," complete Schedule D, Part V

11 If the organization's answer to any of the following questions is "Yes," then complete Schedule D, Parts VI, VII, VIII, IX, or X as applicable.

a Did the organization report an amount for land, buildings, and equipment in Part $X$, line 10? If "Yes," complete Schedule D, Part VI

b Did the organization report an amount for investments-other securities in Part X, line 12 that is $5 \%$ or more of its total assets reported in Part X, line 16? If "Yes," complete Schedule D, Part VII

c Did the organization report an amount for investments-program related in Part X, line 13 that is $5 \%$ or more of its total assets reported in Part X, line 16? If "Yes," complete Schedule D, Part VIII

d Did the organization report an amount for other assets in Part X, line 15 that is $5 \%$ or more of its total assets reported in Part X, line 16? If "Yes," complete Schedule D, Part IX

e Did the organization report an amount for other liabilities in Part X, line 25? If "Yes," complete Schedule D, Part X

$f$ Did the organization's separate or consolidated financial statements for the tax year include a footnote that addresses the organization's liability for uncertain tax positions under FIN 48 (ASC 740)? If "Yes," complete Schedule D, Part X .

12 a Did the organization obtain separate, independent audited financial statements for the tax year? If "Yes," complete Schedule D, Parts XI and XII

b Was the organization included in consolidated, independent audited financial statements for the tax year? If "Yes," and if the organization answered "No" to line 12a, then completing Schedule D, Parts XI and XII is optional

13 Is the organization a school described in section 170(b)(1)(A)(ii)? If "Yes," complete Schedule $E$

14 a Did the organization maintain an office, employees, or agents outside of the United States?

b Did the organization have aggregate revenues or expenses of more than $\$ 10,000$ from grantmaking, fundraising, business, investment, and program service activities outside the United States, or aggregate foreign investments valued at $\$ 100,000$ or more? If "Yes," complete Schedule F, Parts I and IV.

15 Did the organization report on Part IX, column (A), line 3, more than $\$ 5,000$ of grants or other assistance to or for any foreign organization? If "Yes," complete Schedule F, Parts II and IV

16 Did the organization report on Part IX, column (A), line 3, more than $\$ 5,000$ of aggregate grants or other assistance to or for foreign individuals? If "Yes," complete Schedule F, Parts III and IV.

17 Did the organization report a total of more than $\$ 15,000$ of expenses for professional fundraising services on Part IX, column (A), lines 6 and 11e? If "Yes," complete Schedule G, Part I (see instructions)

18 Did the organization report more than $\$ 15,000$ total of fundraising event gross income and contributions on Part VIII, lines 1c and 8a? If "Yes," complete Schedule G, Part II .

19 Did the organization report more than $\$ 15,000$ of gross income from gaming activities on Part VIII, line 9a? If "Yes," complete Schedule G, Part III

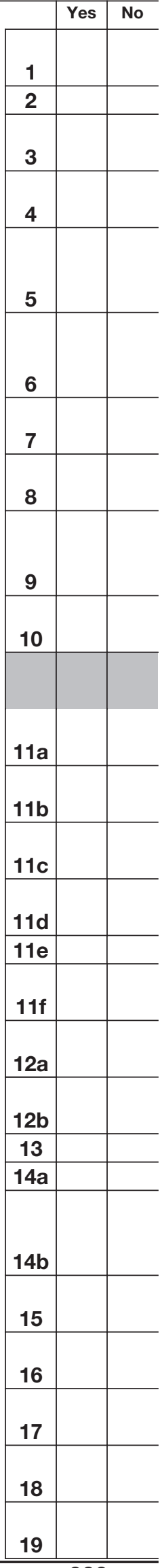

Form $990(2015)$ 
20 a Did the organization operate one or more hospital facilities? If "Yes," complete Schedule $H$

b If "Yes" to line $20 \mathrm{a}$, did the organization attach a copy of its audited financial statements to this return?

21 Did the organization report more than $\$ 5,000$ of grants or other assistance to any domestic organization or domestic government on Part IX, column (A), line 1? If "Yes," complete Schedule I, Parts I and II .

Did the organization report more than $\$ 5,000$ of grants or other assistance to or for domestic individuals on Part IX, column (A), line 2? If "Yes," complete Schedule I, Parts I and III

23 Did the organization answer "Yes" to Part VII, Section A, line 3, 4, or 5 about compensation of the organization's current and former officers, directors, trustees, key employees, and highest compensated employees? If "Yes," complete Schedule J .

24a Did the organization have a tax-exempt bond issue with an outstanding principal amount of more than $\$ 100,000$ as of the last day of the year, that was issued after December 31, 2002? If "Yes," answer lines 24b through $24 d$ and complete Schedule K. If "No," go to line $25 a$

b Did the organization invest any proceeds of tax-exempt bonds beyond a temporary period exception? .

c Did the organization maintain an escrow account other than a refunding escrow at any time during the year to defease any tax-exempt bonds?

d Did the organization act as an "on behalf of" issuer for bonds outstanding at any time during the year? .

25a Section 501(c)(3), 501(c)(4), and 501(c)(29) organizations. Did the organization engage in an excess benefit transaction with a disqualified person during the year? If "Yes," complete Schedule L, Part I

b Is the organization aware that it engaged in an excess benefit transaction with a disqualified person in a prior year, and that the transaction has not been reported on any of the organization's prior Forms 990 or $990-E Z$ ? If "Yes," complete Schedule L, Part I .

26 Did the organization report any amount on Part X, line 5, 6, or 22 for receivables from or payables to any current or former officers, directors, trustees, key employees, highest compensated employees, or disqualified persons? If "Yes," complete Schedule L, Part II

27 Did the organization provide a grant or other assistance to an officer, director, trustee, key employee, substantial contributor or employee thereof, a grant selection committee member, or to a $35 \%$ controlled entity or family member of any of these persons? If "Yes," complete Schedule L, Part III

Was the organization a party to a business transaction with one of the following parties (see Schedule L, Part IV instructions for applicable filing thresholds, conditions, and exceptions):

a A current or former officer, director, trustee, or key employee? If "Yes," complete Schedule L, Part IV

b A family member of a current or former officer, director, trustee, or key employee? If "Yes," complete Schedule L, Part IV

c An entity of which a current or former officer, director, trustee, or key employee (or a family member thereof) was an officer, director, trustee, or direct or indirect owner? If "Yes," complete Schedule L, Part IV

29 Did the organization receive more than $\$ 25,000$ in non-cash contributions? If "Yes," complete Schedule $M$

30 Did the organization receive contributions of art, historical treasures, or other similar assets, or qualified conservation contributions? If "Yes," complete Schedule $M$

31 Did the organization liquidate, terminate, or dissolve and cease operations? If "Yes," complete Schedule N, Part I

Did the organization sell, exchange, dispose of, or transfer more than $25 \%$ of its net assets? If "Yes," complete Schedule N, Part II

33 Did the organization own $100 \%$ of an entity disregarded as separate from the organization under Regulations sections 301.7701-2 and 301.7701-3? If "Yes," complete Schedule R, Part I .

Was the organization related to any tax-exempt or taxable entity? If "Yes," complete Schedule R, Part II, III, or $I V$, and Part $V$, line 1

35a Did the organization have a controlled entity within the meaning of section 512(b)(13)?

b If "Yes" to line $35 \mathrm{a}$, did the organization receive any payment from or engage in any transaction with a controlled entity within the meaning of section 512(b)(13)? If "Yes," complete Schedule R, Part V, line 2 .

36 Section $\mathbf{5 0 1 ( c ) ( 3 ) ~ o r g a n i z a t i o n s . ~ D i d ~ t h e ~ o r g a n i z a t i o n ~ m a k e ~ a n y ~ t r a n s f e r s ~ t o ~ a n ~ e x e m p t ~ n o n - c h a r i t a b l e ~}$ related organization? If "Yes," complete Schedule R, Part V, line 2 .

37 Did the organization conduct more than $5 \%$ of its activities through an entity that is not a related organization and that is treated as a partnership for federal income tax purposes? If "Yes," complete Schedule R,

Part VI.

38 Did the organization complete Schedule O and provide explanations in Schedule O for Part VI, lines 11b and 19? Note. All Form 990 filers are required to complete Schedule O.

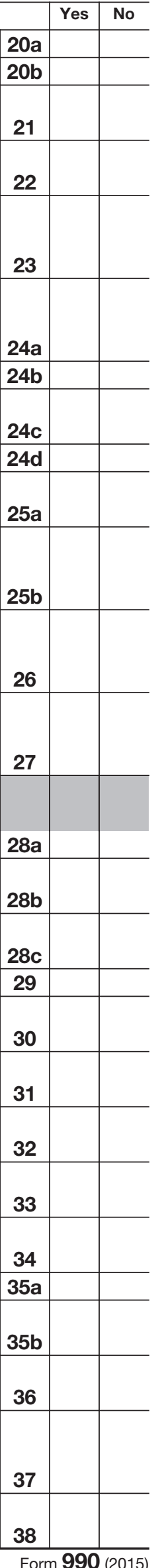


1a Enter the number reported in Box 3 of Form 1096. Enter -0- if not applicable

b Enter the number of Forms W-2G included in line 1a. Enter -0- if not applicable .

c Did the organization comply with backup withholding rules for reportable payments to vendors and reportable gaming (gambling) winnings to prize winners?

2a Enter the number of employees reported on Form W-3, Transmittal of Wage and Tax Statements, filed for the calendar year ending with or within the year covered by this return

\section{$2 a$}

b If at least one is reported on line $2 a$, did the organization file all required federal employment tax returns? Note. If the sum of lines $1 a$ and $2 a$ is greater than 250 , you may be required to e-file (see instructions) . .

3a Did the organization have unrelated business gross income of $\$ 1,000$ or more during the year?

b If "Yes," has it filed a Form 990-T for this year? If "No" to line 3b, provide an explanation in Schedule O .

4a At any time during the calendar year, did the organization have an interest in, or a signature or other authority over, a financial account in a foreign country (such as a bank account, securities account, or other financial account)?

b If "Yes," enter the name of the foreign country:

See instructions for filing requirements for FinCEN Form 114, Report of Foreign Bank and Financial Accounts (FBAR).

5a Was the organization a party to a prohibited tax shelter transaction at any time during the tax year?

b

c If "Yes" to line $5 \mathrm{a}$ or $5 \mathrm{~b}$, did the organization file Form 8886-T?

6a Does the organization have annual gross receipts that are normally greater than $\$ 100,000$, and did the organization solicit any contributions that were not tax deductible as charitable contributions? .

b If "Yes," did the organization include with every solicitation an express statement that such contributions or gifts were not tax deductible?

7 Organizations that may receive deductible contributions under section 170(c).

a Did the organization receive a payment in excess of $\$ 75$ made partly as a contribution and partly for goods and services provided to the payor?

b If "Yes," did the organization notify the donor of the value of the goods or services provided?

c Did the organization sell, exchange, or otherwise dispose of tangible personal property for which it was required to file Form 8282 ?

d If "Yes," indicate the number of Forms 8282 filed during the year

\section{7d}

e Did the organization receive any funds, directly or indirectly, to pay premiums on a personal benefit contract?

f Did the organization, during the year, pay premiums, directly or indirectly, on a personal benefit contract? .

g If the organization received a contribution of qualified intellectual property, did the organization file Form 8899 as required?

h If the organization received a contribution of cars, boats, airplanes, or other vehicles, did the organization file a Form 1098-C?

8 Sponsoring organizations maintaining donor advised funds. Did a donor advised fund maintained by the sponsoring organization have excess business holdings at any time during the year?

9 Sponsoring organizations maintaining donor advised funds.

a Did the sponsoring organization make any taxable distributions under section 4966 ?

b Did the sponsoring organization make a distribution to a donor, donor advisor, or related person?

10 Section 501(c)(7) organizations. Enter:

a Initiation fees and capital contributions included on Part VIII, line 12

b Gross receipts, included on Form 990, Part VIII, line 12, for public use of club facilities

11 Section 501(c)(12) organizations. Enter:

a Gross income from members or shareholders.

b Gross income from other sources (Do not net amounts due or paid to other sources against amounts due or received from them.)

b If "Yes," enter the amount of tax-exempt interest received or accrued during the year.

13 Section 501(c)(29) qualified nonprofit health insurance issuers.

a Is the organization licensed to issue qualified health plans in more than one state? Note. See the instructions for additional information the organization must report on Schedule $\mathrm{O}$.

b Enter the amount of reserves the organization is required to maintain by the states in which the organization is licensed to issue qualified health plans

c Enter the amount of reserves on hand

14a Did the organization receive any payments for indoor tanning services during the tax year? .

b If "Yes," has it filed a Form 720 to report these payments? If "No," provide an explanation in Schedule O 10a

$10 b$

\begin{tabular}{|c|}
$11 a$ \\
$11 b$ \\
\hline
\end{tabular}

$12 b$
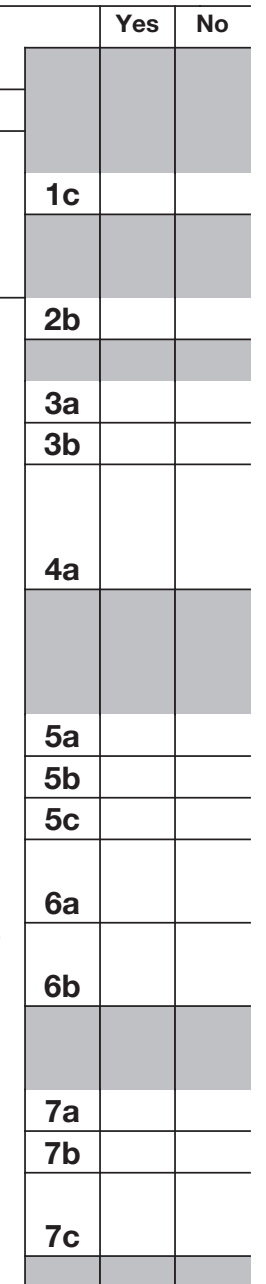

\begin{tabular}{|l|l|l}
\hline $7 e$ & & \\
\hline $7 f$ & & \\
\hline $7 g$ & & \\
\hline $7 h$ & & \\
\hline
\end{tabular}

7

8
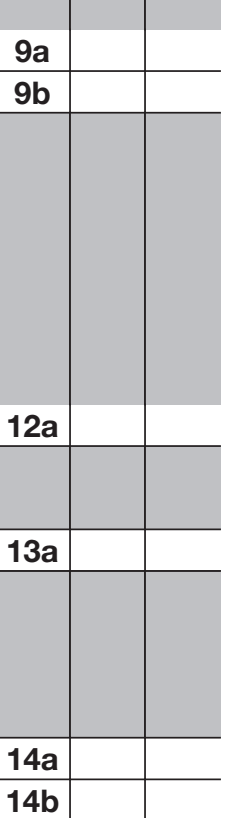

Form $\mathbf{9 9 0}$ (2015) 
Part VI Governance, Management, and Disclosure For each "Yes" response to lines 2 through $7 \mathrm{~b}$ below, and for a "No" response to line 8a, 8b, or $10 b$ below, describe the circumstances, processes, or changes in Schedule O. See instructions. Check if Schedule O contains a response or note to any line in this Part VI

\section{Section A. Governing Body and Management}

1a Enter the number of voting members of the governing body at the end of the tax year. If there are material differences in voting rights among members of the governing body, or if the governing body delegated broad authority to an executive committee or similar committee, explain in Schedule O.

b Enter the number of voting members included in line 1a, above, who are independent

\begin{tabular}{|l}
$1 a$ \\
$1 b$
\end{tabular}

2 Did any officer, director, trustee, or key employee have a family relationship or a business relationship with any other officer, director, trustee, or key employee?

3 Did the organization delegate control over management duties customarily performed by or under the direct supervision of officers, directors, or trustees, or key employees to a management company or other person?

4 Did the organization make any significant changes to its governing documents since the prior Form 990 was filed?

5 Did the organization become aware during the year of a significant diversion of the organization's assets? .

6 Did the organization have members or stockholders?

7a Did the organization have members, stockholders, or other persons who had the power to elect or appoint one or more members of the governing body?

b Are any governance decisions of the organization reserved to (or subject to approval by) members, stockholders, or persons other than the governing body?

8 Did the organization contemporaneously document the meetings held or written actions undertaken during the year by the following:

a The governing body?

b Each committee with authority to act on behalf of the governing body?

9 Is there any officer, director, trustee, or key employee listed in Part VII, Section A, who cannot be reached at the organization's mailing address? If "Yes," provide the names and addresses in Schedule $O$.

Section B. Policies (This Section B requests information about policies not required by the Internal Revenue Code.)

10a Did the organization have local chapters, branches, or affiliates?

b If "Yes," did the organization have written policies and procedures governing the activities of such chapters, affiliates, and branches to ensure their operations are consistent with the organization's exempt purposes?

11a Has the organization provided a complete copy of this Form 990 to all members of its governing body before filing the form?

b Describe in Schedule O the process, if any, used by the organization to review this Form 990.

12a Did the organization have a written conflict of interest policy? If "No," go to line 13

b Were officers, directors, or trustees, and key employees required to disclose annually interests that could give rise to conflicts?

c Did the organization regularly and consistently monitor and enforce compliance with the policy? If "Yes," describe in Schedule O how this was done.

13 Did the organization have a written whistleblower policy? . . . . . . . . . . . . . . . . . . . . . . . . . . .

14 Did the organization have a written document retention and destruction policy?

15 Did the process for determining compensation of the following persons include a review and approval by independent persons, comparability data, and contemporaneous substantiation of the deliberation and decision?

a The organization's CEO, Executive Director, or top management official

b Other officers or key employees of the organization If "Yes" to line $15 \mathrm{a}$ or 15b, describe the process in Schedule O (see instructions).

16a Did the organization invest in, contribute assets to, or participate in a joint venture or similar arrangement with a taxable entity during the year?

b If "Yes," did the organization follow a written policy or procedure requiring the organization to evaluate its participation in joint venture arrangements under applicable federal tax law, and take steps to safeguard the organization's exempt status with respect to such arrangements?

\begin{tabular}{|c|l|l}
\multicolumn{1}{r|}{} & Yes & No \\
\hline $10 a$ & & \\
\hline $10 b$ & & \\
\hline $11 a$ & & \\
\hline $12 a$ & & \\
\hline $12 b$ & & \\
\hline $12 c$ & & \\
\hline 13 & & \\
\hline 14 & & \\
\hline & & \\
\hline $15 a$ & & \\
\hline $15 b$ & & \\
\hline & & \\
\hline $16 a$ & & \\
\hline & & \\
\hline $16 b$ & & \\
\hline
\end{tabular}

\section{Section C. Disclosure}

17 List the states with which a copy of this Form 990 is required to be filed

18 Section 6104 requires an organization to make its Forms 1023 (or 1024 if applicable), 990, and 990-T (Section 501(c)(3)s only) available for public inspection. Indicate how you made these available. Check all that apply.

$\square$ Own website $\square$ Another's website $\quad \square$ Upon request $\quad \square$ Other (explain in Schedule O)

19 Describe in Schedule O whether (and if so, how) the organization made its governing documents, conflict of interest policy, and financial statements available to the public during the tax year.

20 State the name, address, and telephone number of the person who possesses the organization's books and records: 
Part VII Compensation of Officers, Directors, Trustees, Key Employees, Highest Compensated Employees, and Independent Contractors

Check if Schedule O contains a response or note to any line in this Part VII

\section{Section A. Officers, Directors, Trustees, Key Employees, and Highest Compensated Employees}

1a Complete this table for all persons required to be listed. Report compensation for the calendar year ending with or within the organization's tax year.

- List all of the organization's current officers, directors, trustees (whether individuals or organizations), regardless of amount of compensation. Enter - 0 - in columns (D), (E), and ( $F$ ) if no compensation was paid.

- List all of the organization's current key employees, if any. See instructions for definition of "key employee."

- List the organization's five current highest compensated employees (other than an officer, director, trustee, or key employee) who received reportable compensation (Box 5 of Form W-2 and/or Box 7 of Form 1099-MISC) of more than $\$ 100,000$ from the organization and any related organizations.

- List all of the organization's former officers, key employees, and highest compensated employees who received more than $\$ 100,000$ of reportable compensation from the organization and any related organizations.

- List all of the organization's former directors or trustees that received, in the capacity as a former director or trustee of the organization, more than $\$ 10,000$ of reportable compensation from the organization and any related organizations.

List persons in the following order: individual trustees or directors; institutional trustees; officers; key employees; highest compensated employees; and former such persons.

Check this box if neither the organization nor any related organization compensated any current officer, director, or trustee.

(A)

Name and Title

(1)

$(2)$

(3)

(4)

(5)

(6)

(7)

(8)

(9)

(10)

(11)

(12)

(13)

(14)

(B)

Average

hours per

week (list any

hours for

related

organizations

below dotted

line)

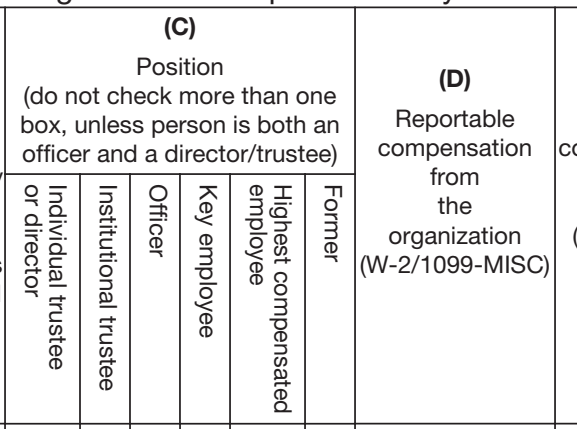

(C)

fficer and a director/trustee)

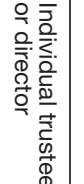

(E)

Reportable

compensation from related

organizations (W-2/1099-MISC)
(F)

\section{Estimated} amount of other compensation

from the

organization

and related organizations

(1)

(1)

(5)

(6)

)

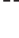

\begin{tabular}{ll|l|l|l|l|l|l|l}
\hline & & & & & & & & \\
\hline
\end{tabular}

$+0$


Part VII Section A. Officers, Directors, Trustees, Key Employees, and Highest Compensated Employees (continued)

(A)

Name and title
(B)

Average hours per week (list any

hours for related organizations below dotted line)

(15)

(16)

(17)

(18)

(19)

(20)

(21)

(22)

(23)

(24)

(25)

1 Sub-total

d Total (add lines $\mathbf{1 b}$ and 1c)

2 Total number of individuals (including but not limited to those listed above) who received more than $\$ 100,000$ of reportable compensation from the organization

3 Did the organization list any former officer, director, or trustee, key employee, or highest compensated employee on line 1a? If "Yes," complete Schedule $J$ for such individual

4 For any individual listed on line 1a, is the sum of reportable compensation and other compensation from the organization and related organizations greater than $\$ 150,000$ ? If "Yes," complete Schedule $J$ for such individual

5 Did any person listed on line 1a receive or accrue compensation from any unrelated organization or individual for services rendered to the organization? If "Yes," complete Schedule $J$ for such person

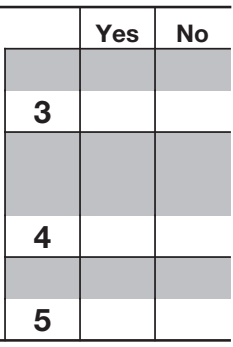

\section{Section B. Independent Contractors}

1 Complete this table for your five highest compensated independent contractors that received more than $\$ 100,000$ of compensation from the organization. Report compensation for the calendar year ending with or within the organization's tax year.

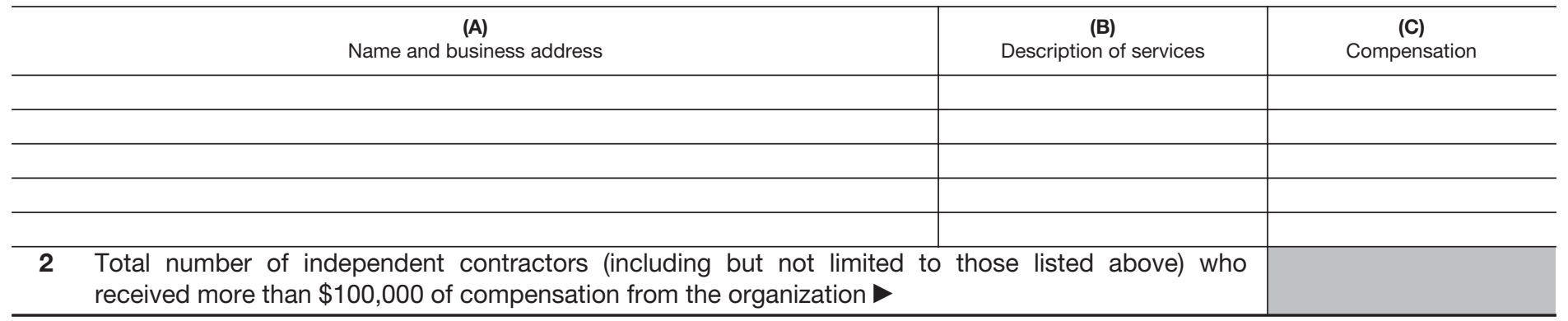




\section{Part VIII Statement of Revenue}

Check if Schedule O contains a response or note to any line in this Part VIII

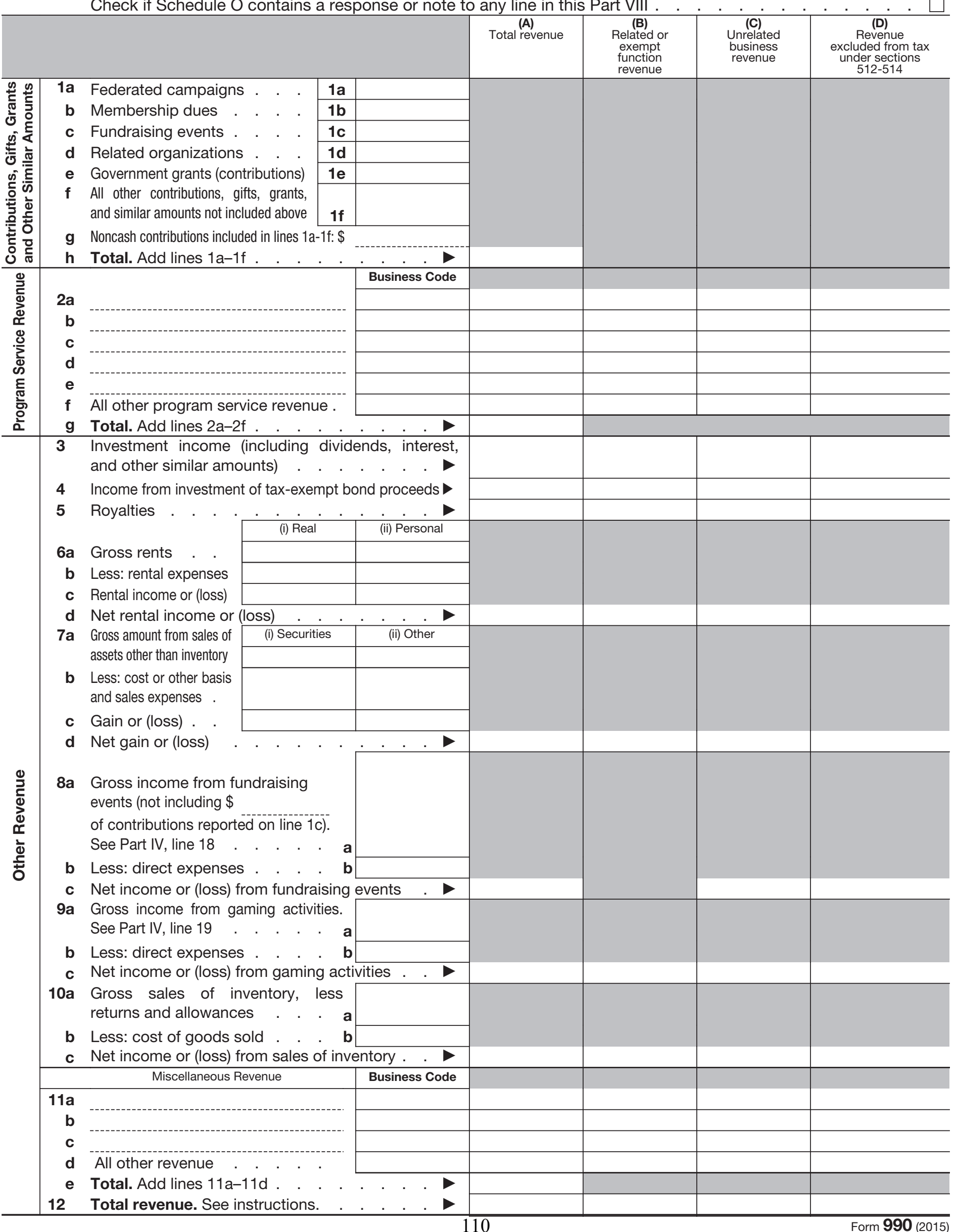




\section{Part IX Statement of Functional Expenses}

Section 501(c)(3) and 501(c)(4) organizations must complete all columns. All other organizations must complete column (A).

Check if Schedule O contains a response or note to any line in this Part IX

\section{Do not include amounts reported on lines $6 b, 7 b$, $8 b, 9 b$, and $10 b$ of Part VIII.}

1 Grants and other assistance to domestic organizations and domestic governments. See Part IV, line 21

2 Grants and other assistance to domestic individuals. See Part IV, line 22 . . . . . . .

3 Grants and other assistance to foreign organizations, foreign governments, and foreign individuals. See Part IV, lines 15 and 16 .

4 Benefits paid to or for members

5 Compensation of current officers, directors trustees, and key employees

6 Compensation not included above, to disqualified persons (as defined under section 4958(f)(1)) and persons described in section 4958(C)(3)(B)

7 Other salaries and wages

8 Pension plan accruals and contributions (include section 401(k) and 403(b) employer contributions)

9 Other employee benefits

10 Payroll taxes.

11 Fees for services (non-employees):

a Management

b Legal

d Lobbying . . . . . . . . . . . . .

e Professional fundraising services. See Part IV, line 17

f Investment management fees . . . . .

g Other. (If line $11 \mathrm{~g}$ amount exceeds $10 \%$ of line 25 , column (A) amount, list line $11 \mathrm{~g}$ expenses on Schedule 0.)

Advertising and promotion

13 Office expenses

e All other expenses

Total functional expenses. Add lines 1 through $24 \mathrm{e}$ organization reported in column (B) joint costs from a combined educational campaign and fundraising solicitation. Check here following SOP 98-2 (ASC 958-720)

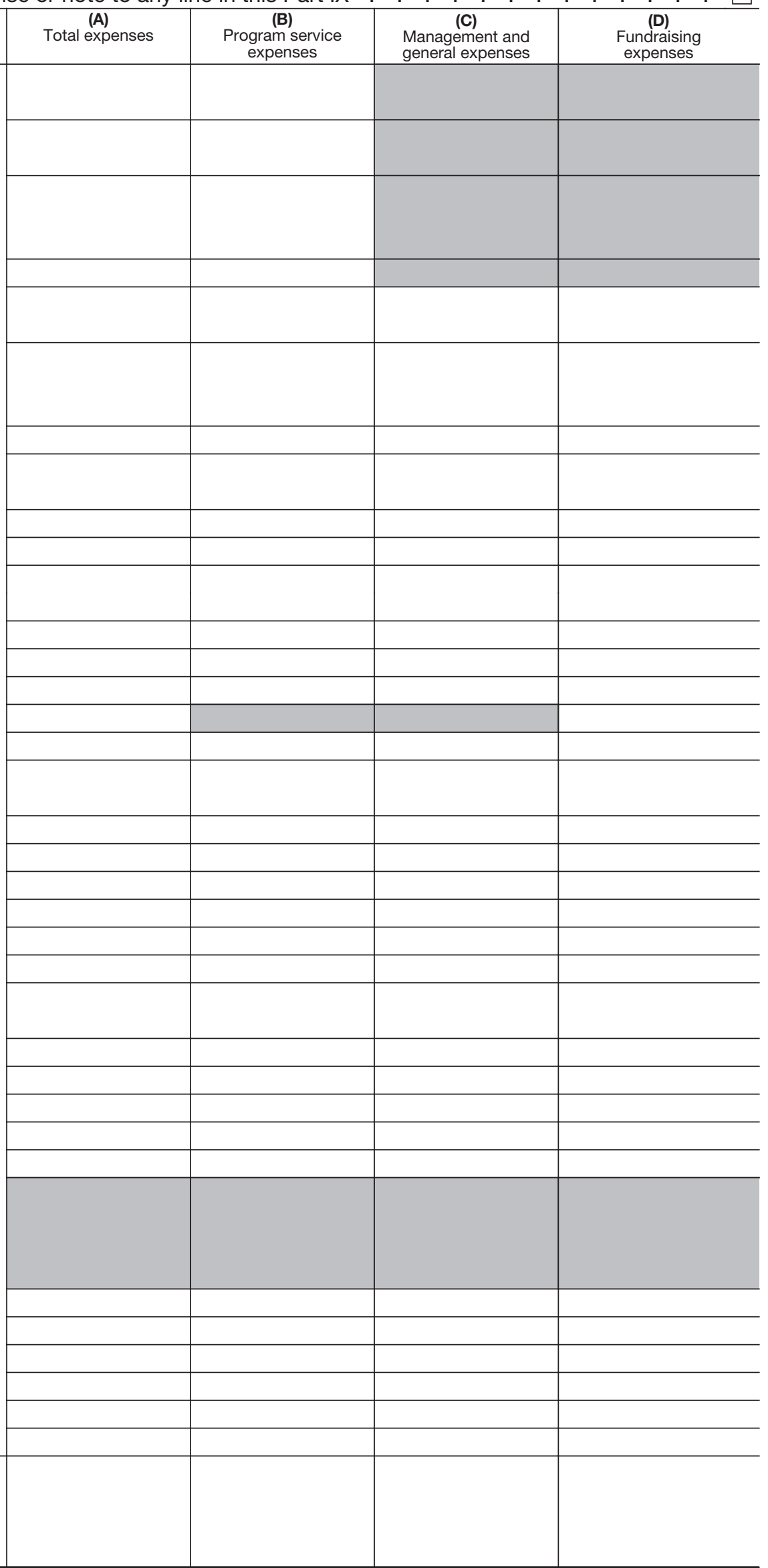


1 Cash-non-interest-bearing

2 Savings and temporary cash investments

3 Pledges and grants receivable, net

4 Accounts receivable, net

5 Loans and other receivables from current and former officers, directors, trustees, key employees, and highest compensated employees. Complete Part II of Schedule L

6 Loans and other receivables from other disqualified persons (as defined under section 4958(f)(1)), persons described in section 4958(c)(3)(B), and contributing employers and sponsoring organizations of section 501(c)(9) voluntary employees' beneficiary organizations (see instructions). Complete Part II of Schedule L

7 Notes and loans receivable, net

8 Inventories for sale or use

9 Prepaid expenses and deferred charges

10a Land, buildings, and equipment: cost or other basis. Complete Part VI of Schedule D

b Less: accumulated depreciation . . . .

11 Investments - publicly traded securities

12 Investments - other securities. See Part IV, line 11

13 Investments-program-related. See Part IV, line 11

14 Intangible assets

15 Other assets. See Part IV, line 11

16 Total assets. Add lines 1 through 15 (must equal line 34)

17 Accounts payable and accrued expenses

18 Grants payable.

19 Deferred revenue

20 Tax-exempt bond liabilities

21 Escrow or custodial account liability. Complete Part IV of Schedule D .

22 Loans and other payables to current and former officers, directors, trustees, key employees, highest compensated employees, and disqualified persons. Complete Part II of Schedule L

23 Secured mortgages and notes payable to unrelated third parties

24 Unsecured notes and loans payable to unrelated third parties

25 Other liabilities (including federal income tax, payables to related third parties, and other liabilities not included on lines 17-24). Complete Part X of Schedule D

26 Total liabilities. Add lines 17 through 25

Organizations that follow SFAS 117 (ASC 958), check here $\square$ and complete lines 27 through 29, and lines 33 and 34 .

27 Unrestricted net assets

28 Temporarily restricted net assets

29 Permanently restricted net assets.

Organizations that do not follow SFAS 117 (ASC 958), check here complete lines 30 through 34 .

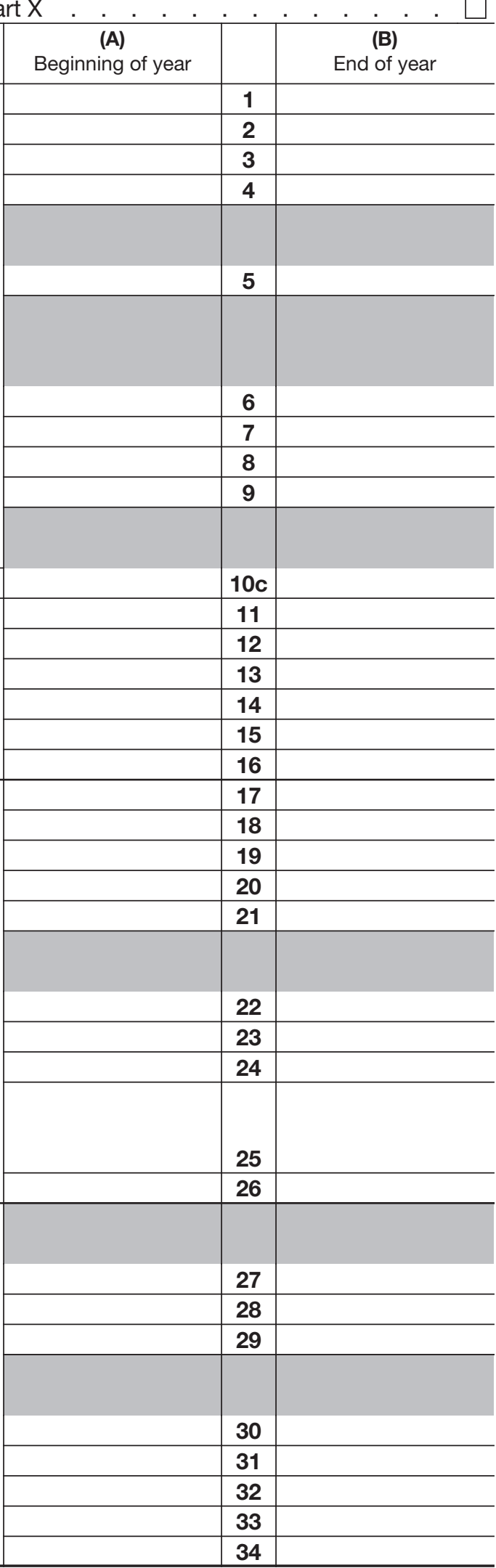




\section{Part XI Reconciliation of Net Assets}

Check if Schedule O contains a response or note to any line in this Part X

1 Total revenue (must equal Part VIII, column (A), line 12)

2 Total expenses (must equal Part IX, column (A), line 25)

3 Revenue less expenses. Subtract line 2 from line 1

Net assets or fund balances at beginning of year (must equal Part X, line 33, column (A)) . .

5 Net unrealized gains (losses) on investments . . . . . . . . . . . . . . . . . . . . . . .

6 Donated services and use of facilities

7 Investment expenses.

8 Prior period adjustments

9 Other changes in net assets or fund balances (explain in Schedule O) . . . . . . . . . . . .

10 Net assets or fund balances at end of year. Combine lines 3 through 9 (must equal Part $X$, line

33, column (B))

\section{Part XII Financial Statements and Reporting}

Check if Schedule O contains a response or note to any line in this Part XII

1 Accounting method used to prepare the Form 990: $\square$ Cash $\square$ Accrual $\quad \square$ Other

If the organization changed its method of accounting from a prior year or checked "Other," explain in Schedule O.

2a Were the organization's financial statements compiled or reviewed by an independent accountant? . . . If "Yes," check a box below to indicate whether the financial statements for the year were compiled or reviewed on a separate basis, consolidated basis, or both:

$\square$ Separate basis $\square$ Consolidated basis $\square$ Both consolidated and separate basis

b Were the organization's financial statements audited by an independent accountant?

If "Yes," check a box below to indicate whether the financial statements for the year were audited on a separate basis, consolidated basis, or both:

$\square$ Separate basis $\square$ Consolidated basis $\square$ Both consolidated and separate basis

c If "Yes" to line $2 \mathrm{a}$ or $2 \mathrm{~b}$, does the organization have a committee that assumes responsibility for oversight of the audit, review, or compilation of its financial statements and selection of an independent accountant?

If the organization changed either its oversight process or selection process during the tax year, explain in Schedule O.

3a As a result of a federal award, was the organization required to undergo an audit or audits as set forth in the Single Audit Act and OMB Circular A-133? .

b If "Yes," did the organization undergo the required audit or audits? If the organization did not undergo the required audit or audits, explain why in Schedule $\mathrm{O}$ and describe any steps taken to undergo such audits.

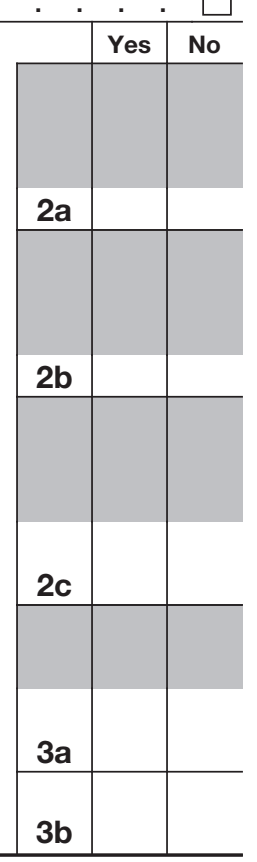




\section{Chester College of New England}

\begin{tabular}{|c|c|c|c|c|c|c|c|c|}
\hline Year & 2005 & 2006 & 2007 & 2008 & 2009 & 2010 & 2011 & 2012 \\
\hline MRA Composite Index & & & 1.2 & 1.3 & 1.4 & 1.3 & 0.8 & 0.2 \\
\hline FRCS & & & 2.1 & 2.1 & 2.1 & 1.6 & 1.9 & 0.6 \\
\hline \multicolumn{9}{|l|}{ Index Components } \\
\hline Primary Reserve Ratio (25\%) & 0.30 & 0.14 & 0.28 & 0.26 & 0.41 & 0.27 & 0.33 & -0.25 \\
\hline Equity Ratio (12.5\%) & 0.27 & 0.26 & 0.32 & 0.34 & 0.32 & 0.38 & 0.38 & 0.38 \\
\hline Return on Net Assets Ratio (12.5\%) & 0.24 & -0.04 & 0.38 & 0.38 & 0.36 & 0.38 & -0.06 & -0.13 \\
\hline Net Operating Revenues Ratio (25\%) & 0.45 & 0.33 & 0.75 & 0.55 & 0.57 & -0.08 & -0.25 & -0.25 \\
\hline Risk Factors (25\%) & -0.25 & -0.25 & 0.00 & -0.25 & -0.25 & 0.25 & 0.00 & 0.00 \\
\hline MRA Index (Single Year) & 1.0 & 0.4 & 1.7 & 1.3 & 1.4 & 1.2 & 0.4 & -0.3 \\
\hline \multicolumn{9}{|l|}{ Primary Reserve Ratio } \\
\hline Unrestricted Net Assets & $\$ 1,173,572$ & $\$ 1,196,855$ & $\$ 1,513,917$ & $\$ 1,620,494$ & $\$ 1,732,646$ & $\$ 1,504,759$ & $\$ 1,118,097$ & $\$ 424,498$ \\
\hline Temporarily-restricted Net Assets & $\$ 80,187$ & $\$ 20,816$ & $\$ 18,307$ & $\$ 96,998$ & $\$ 54,724$ & $\$ 25,137$ & $\$ 26,994$ & $\$ 26,994$ \\
\hline $\begin{array}{l}\text { Land, Building and Equipment, } \\
\text { net of depreciation }\end{array}$ & $\$ 3,102,331$ & $\$ 3,227,941$ & $\$ 3,165,999$ & $\$ 3,301,832$ & $\$ 3,646,150$ & $\$ 3,513,430$ & $\$ 3,397,997$ & $\$ 3,218,525$ \\
\hline Long-term Debt & $\$ 2,269,059$ & $\$ 2,230,016$ & $\$ 2,147,284$ & $\$ 2,062,528$ & $\$ 2,595,306$ & $\$ 2,486,861$ & $\$ 2,831,693$ & $\$ 2,280,289$ \\
\hline Total Expenses & $\$ 3,467,510$ & $\$ 4,056,654$ & $\$ 4,573,759$ & $\$ 4,552,282$ & $\$ 4,515,607$ & \begin{tabular}{|l|}
$\$ 4,579,798$ \\
\end{tabular} & $\$ 4,385,941$ & $\$ 4,330,648$ \\
\hline Ratio & \begin{tabular}{l|l}
0.12 \\
\end{tabular} & 0.05 & 0.11 & 0.11 & 0.16 & 0.11 & 0.13 & -0.11 \\
\hline Strength Factor & 1.21 & 0.54 & 1.12 & 1.05 & 1.63 & 1.10 & 1.32 & -1.00 \\
\hline Weighted Value (25\%) & \begin{tabular}{l|l}
0.30 \\
\end{tabular} & 0.14 & 0.28 & 0.26 & 0.41 & 0.27 & 0.33 & -0.25 \\
\hline
\end{tabular}

\begin{tabular}{|c|c|c|c|c|c|c|c|c|}
\hline \multicolumn{9}{|l|}{ Equity Ratio } \\
\hline Net Assets & $\$ 1,318,064$ & $\$ 1,310,382$ & $\$ 1,700,494$ & $\$ 1,972,145$ & $\$ 2,086,733$ & $\$ 4,583,517$ & $\$ 4,542,990$ & $\$ 3,884,940$ \\
\hline Intangible Assets & $\$ 0$ & $\$ 0$ & $\$ 0$ & $\$ 0$ & $\$ 0$ & $\$ 0$ & $\$ 0$ & $\$ 0$ \\
\hline Unsecured Related-party Receivables & $\$ 0$ & $\$ 0$ & $\$ 0$ & $\$ 0$ & $\$ 0$ & $\$ 0$ & $\$ 0$ & $\$ 0$ \\
\hline Total Assets & $\$ 3,656,310$ & $\$ 3,719,425$ & $\$ 3,984,580$ & $\$ 4,351,721$ & $\$ 4,850,865$ & $\$ 7,295,531$ & $\$ 7,600,074$ & $\$ 6,268,592$ \\
\hline - Intangible Assets & $\$ 0$ & $\$ 0$ & $\$ 0$ & $\$ 0$ & $\$ 0$ & $\$ 0$ & $\$ 0$ & $\$ 0$ \\
\hline - Unsecured Related-party Receivables & $\$ 0$ & $\$ 0$ & $\$ 0$ & $\$ 0$ & $\$ 0$ & $\$ 0$ & $\$ 0$ & $\$ 0$ \\
\hline Ratio & 0.36 & 0.35 & 0.43 & 0.45 & 0.43 & 0.63 & 0.60 & 0.62 \\
\hline Strength Factor & 2.16 & 2.11 & 2.56 & 2.72 & 2.58 & 3.00 & 3.00 & 3.00 \\
\hline Weighted Value (12.5\%) & 0.27 & 0.26 & 0.32 & 0.34 & 0.32 & 0.38 & 0.38 & 0.38 \\
\hline
\end{tabular}

\begin{tabular}{|c|c|c|c|c|c|c|c|c|}
\hline \multicolumn{9}{|l|}{ Return on Net Assets Ratio } \\
\hline$\Delta$ Net Assets & $\$ 49,634$ & $-\$ 7,682$ & $\$ 390,112$ & $\$ 271,651$ & $\$ 114,588$ & $\$ 2,496,784$ & $-\$ 40,527$ & $-\$ 658,050$ \\
\hline Total Net Assets (BOY) & \begin{tabular}{l|l}
$\$ 1,268,430$ \\
\end{tabular} & $\$ 1,318,064$ & $\$ 1,310,382$ & $\$ 1,700,494$ & $\$ 1,972,145$ & $\$ 2,086,733$ & $\$ 4,583,517$ & $\$ 4,542,990$ \\
\hline Ratio & 0.04 & -0.01 & 0.30 & 0.16 & 0.06 & 1.20 & -0.01 & -0.14 \\
\hline Strength Factor & 1.96 & -0.29 & 3.00 & 3.00 & 2.91 & 3.00 & -0.44 & -1.00 \\
\hline Weighted Value (12.5\%) & 0.24 & -0.04 & 0.38 & 0.38 & 0.36 & 0.38 & -0.06 & -0.13 \\
\hline
\end{tabular}

\begin{tabular}{|c|c|c|c|c|c|c|c|c|}
\hline \multicolumn{9}{|l|}{ Net Operating Revenues Ratio } \\
\hline$\Delta$ Unrestricted Net Assets & $\$ 49,105$ & $\$ 23,283$ & $\$ 317,062$ & $\$ 106,577$ & $\$ 112,152$ & $-\$ 227,887$ & $-\$ 386,662$ & $-\$ 693,599$ \\
\hline Total Unrestricted Revenue & $\$ 3,033,523$ & $\$ 3,768,871$ & $\$ 4,623,626$ & $\$ 4,452,244$ & $\$ 4,392,830$ & $\$ 4,260,921$ & $\$ 3,687,567$ & $\$ 3,574,591$ \\
\hline Ratio & 0.02 & 0.01 & 0.07 & 0.02 & 0.03 & -0.05 & -0.10 & -0.19 \\
\hline Strength Factor & 1.81 & 1.31 & 3.00 & 2.20 & 2.28 & -0.34 & -1.00 & -1.00 \\
\hline Weighted Value (25\%) & 0.45 & 0.33 & 0.75 & 0.55 & 0.57 & -0.08 & -0.25 & -0.25 \\
\hline
\end{tabular}

\begin{tabular}{|c|c|c|c|c|c|c|c|c|}
\hline \multicolumn{9}{|l|}{ Risk Factors } \\
\hline $\begin{array}{l}\text { Enrollment } \\
<1,000(2) \text { or }<2,500(1)\end{array}$ & 179 & 200 & 242 & 211 & 208 & 185 & 160 & 136 \\
\hline $\begin{array}{l}\text { Religious or Non-Degree Granting } \\
\text { yes }\end{array}$ & no & no & no & no & no & no & no & no \\
\hline $\begin{array}{l}\text { Ratio of Full-time to Part-time Students } \\
<3.0\end{array}$ & 1.6 & 3.1 & 67.0 & 40.0 & 48.0 & 10.3 & 12.0 & 17.5 \\
\hline $\begin{array}{l}\text { Tuition Discounting } \\
>60 \%\end{array}$ & $14 \%$ & $18 \%$ & $18 \%$ & $16 \%$ & $18 \%$ & $21 \%$ & $20 \%$ & $20 \%$ \\
\hline $\begin{array}{l}\text { Tuition Reliance } \\
>85 \%\end{array}$ & $96 \%$ & $96 \%$ & $96 \%$ & $93 \%$ & $88 \%$ & $83 \%$ & $84 \%$ & $84 \%$ \\
\hline $\begin{array}{l}\text { Interest Expense } \\
>10 \%\end{array}$ & $5 \%$ & $4 \%$ & $4 \%$ & $4 \%$ & $3 \%$ & $3 \%$ & $3 \%$ & $3 \%$ \\
\hline $\begin{array}{l}\text { Net Revenue } \\
<0\end{array}$ & $\$ 49,634$ & $-\$ 7,682$ & $\$ 390,112$ & $\$ 271,651$ & $\$ 114,588$ & $\$ 2,496,784$ & $-\$ 157,493$ & $-\$ 579,137$ \\
\hline $\begin{array}{l}\text { Endowment/Total Budget } \\
<3.0\end{array}$ & 2.58 & 3.09 & 3.49 & 2.60 & 2.35 & 3.36 & 3.05 & 3.25 \\
\hline Total Risk Factors & 5 & 4 & 3 & 4 & 4 & 2 & 3 & 3 \\
\hline Strength Factor & -1 & -1 & 0 & -1 & -1 & 1 & 0 & 0 \\
\hline Weighted Value (25\%) & -0.25 & -0.25 & 0.00 & -0.25 & -0.25 & 0.25 & 0.00 & 0.00 \\
\hline
\end{tabular}




\section{Dana College}

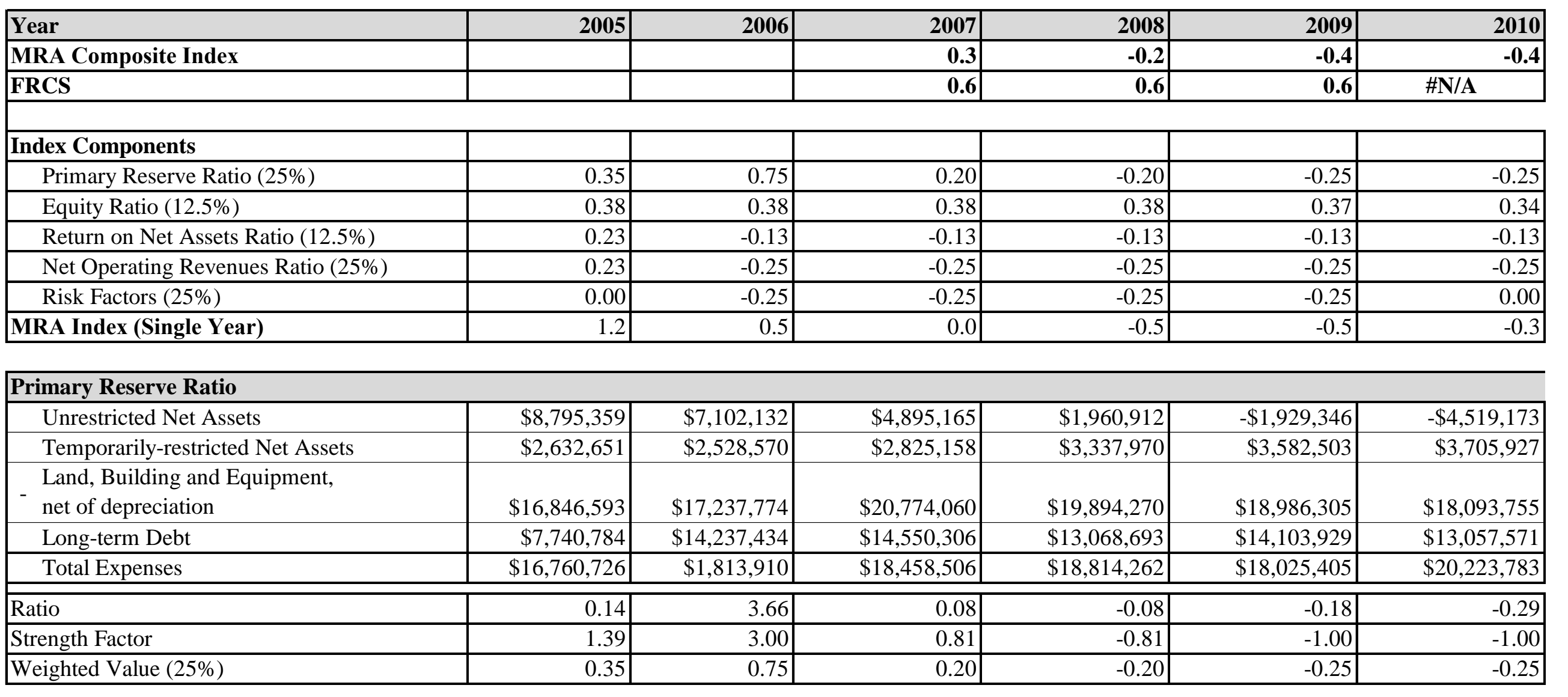

\begin{tabular}{|c|c|c|c|c|c|c|}
\hline \multicolumn{7}{|l|}{ Equity Ratio } \\
\hline Net Assets & $\$ 23,782,887$ & $\$ 22,345,604$ & $\$ 21,498,830$ & $\$ 19,065,506$ & $\$ 14,643,950$ & $\$ 11,874,271$ \\
\hline Intangible Assets & $\$ 0$ & $\$ 0$ & $\$ 0$ & $\$ 0$ & $\$ 0$ & $\$ 0$ \\
\hline Unsecured Related-party Receivables & $\$ 0$ & $\$ 0$ & $\$ 0$ & $\$ 0$ & $\$ 0$ & $\$ 0$ \\
\hline Total Assets & $\$ 32,151,406$ & $\$ 38,013,028$ & $\$ 37,005,455$ & $\$ 33,476,074$ & $\$ 29,693,244$ & $\$ 26,108,101$ \\
\hline - Intangible Assets & $\$ 0$ & $\$ 0$ & $\$ 0$ & $\$ 0$ & $\$ 0$ & $\$ 0$ \\
\hline - Unsecured Related-party Receivables & $\$ 0$ & $\$ 0$ & $\$ 0$ & $\$ 0$ & $\$ 0$ & $\$ 0$ \\
\hline Ratio & 0.74 & 0.59 & 0.58 & 0.57 & 0.49 & 0.45 \\
\hline Strength Factor & 3.00 & 3.00 & 3.00 & 3.00 & 2.96 & 2.73 \\
\hline Weighted Value (12.5\%) & 0.38 & 0.38 & 0.38 & 0.38 & 0.37 & 0.34 \\
\hline \multicolumn{7}{|l|}{ Return on Net Assets Ratio } \\
\hline$\Delta$ Net Assets & $\$ 849,235$ & $-\$ 1,437,283$ & $-\$ 846,774$ & $-\$ 2,433,324$ & $-\$ 4,421,556$ & $-\$ 2,769,679$ \\
\hline Total Net Assets (BOY) & $\$ 22,933,652$ & $\$ 23,782,887$ & $\$ 22,345,604$ & $\$ 21,498,830$ & $\$ 19,065,506$ & $\$ 14,643,950$ \\
\hline Ratio & 0.04 & -0.06 & -0.04 & -0.11 & -0.23 & -0.19 \\
\hline Strength Factor & 1.85 & -1.00 & -1.00 & -1.00 & -1.00 & -1.00 \\
\hline Weighted Value (12.5\%) & 0.23 & -0.13 & -0.13 & \begin{tabular}{|l|l|}
-0.13 \\
\end{tabular} & \begin{tabular}{|l|l|}
-0.13 \\
\end{tabular} & -0.13 \\
\hline
\end{tabular}

\begin{tabular}{|c|c|c|c|c|c|c|}
\hline \multicolumn{7}{|l|}{ Net Operating Revenues Ratio } \\
\hline$\Delta$ Unrestricted Net Assets & $-\$ 39,945$ & $-\$ 1,693,227$ & $-\$ 2,206,967$ & $-\$ 2,934,253$ & $-\$ 3,890,258$ & $-\$ 2,589,827$ \\
\hline Total Unrestricted Revenue & $\$ 13,179,138$ & $\$ 14,149,497$ & $\$ 14,433,170$ & $\$ 13,457,132$ & $\$ 13,237,037$ & $\$ 14,643,115$ \\
\hline Ratio & 0.00 & -0.12 & -0.15 & -0.22 & -0.29 & -0.18 \\
\hline Strength Factor & 0.92 & -1.00 & -1.00 & -1.00 & -1.00 & -1.00 \\
\hline Weighted Value (25\%) & 0.23 & -0.25 & -0.25 & -0.25 & -0.25 & -0.25 \\
\hline
\end{tabular}

\begin{tabular}{|c|c|c|c|c|c|c|}
\hline \multicolumn{7}{|l|}{ Risk Factors } \\
\hline $\begin{array}{l}\text { Enrollment } \\
<1,000(2) \text { or }<2,500(1)\end{array}$ & 627 & 660 & 594 & 616 & 539 & 584 \\
\hline $\begin{array}{l}\text { Religious or Non-Degree Granting } \\
\text { yes }\end{array}$ & no & no & no & no & no & no \\
\hline $\begin{array}{l}\text { Ratio of Full-time to Part-time Students } \\
<3.0\end{array}$ & no $P / T$ & no $\mathrm{P} / \mathrm{T}$ & no $\mathrm{P} / \mathrm{T}$ & no $\mathrm{P} / \mathrm{T}$ & no $\mathrm{P} / \mathrm{T}$ & no $\mathrm{P} / \mathrm{T}$ \\
\hline $\begin{array}{l}\text { Tuition Discounting } \\
>60 \%\end{array}$ & $56 \%$ & $57 \%$ & $56 \%$ & $56 \%$ & $55 \%$ & $55 \%$ \\
\hline $\begin{array}{l}\text { Tuition Reliance } \\
>85 \%\end{array}$ & $52 \%$ & $69 \%$ & $63 \%$ & $67 \%$ & $66 \%$ & $66 \%$ \\
\hline $\begin{array}{l}\text { Interest Expense } \\
>10 \%\end{array}$ & $2 \%$ & $29 \%$ & $3 \%$ & $3 \%$ & $3 \%$ & $3 \%$ \\
\hline $\begin{array}{l}\text { Net Revenue } \\
<0\end{array}$ & $\$ 864,751$ & $\$ 14,850,478$ & $-\$ 908,934$ & $-\$ 2,411,140$ & $-\$ 2,797,737$ & $-\$ 2,769,677$ \\
\hline $\begin{array}{l}\text { Endowment/Total Budget } \\
<3.0\end{array}$ & 1.63 & 0.14 & 1.54 & 2.02 & 2.57 & 0.00 \\
\hline Total Risk Factors & 3 & 4 & 4 & 4 & 4 & 3 \\
\hline Strength Factor & 0 & -1 & -1 & -1 & \begin{tabular}{l|l}
-1 & \\
\end{tabular} & 0 \\
\hline Weighted Value $(25 \%)$ & 0.00 & -0.25 & -0.25 & -0.25 & -0.25 & 0.00 \\
\hline
\end{tabular}




\section{Lambuth University}

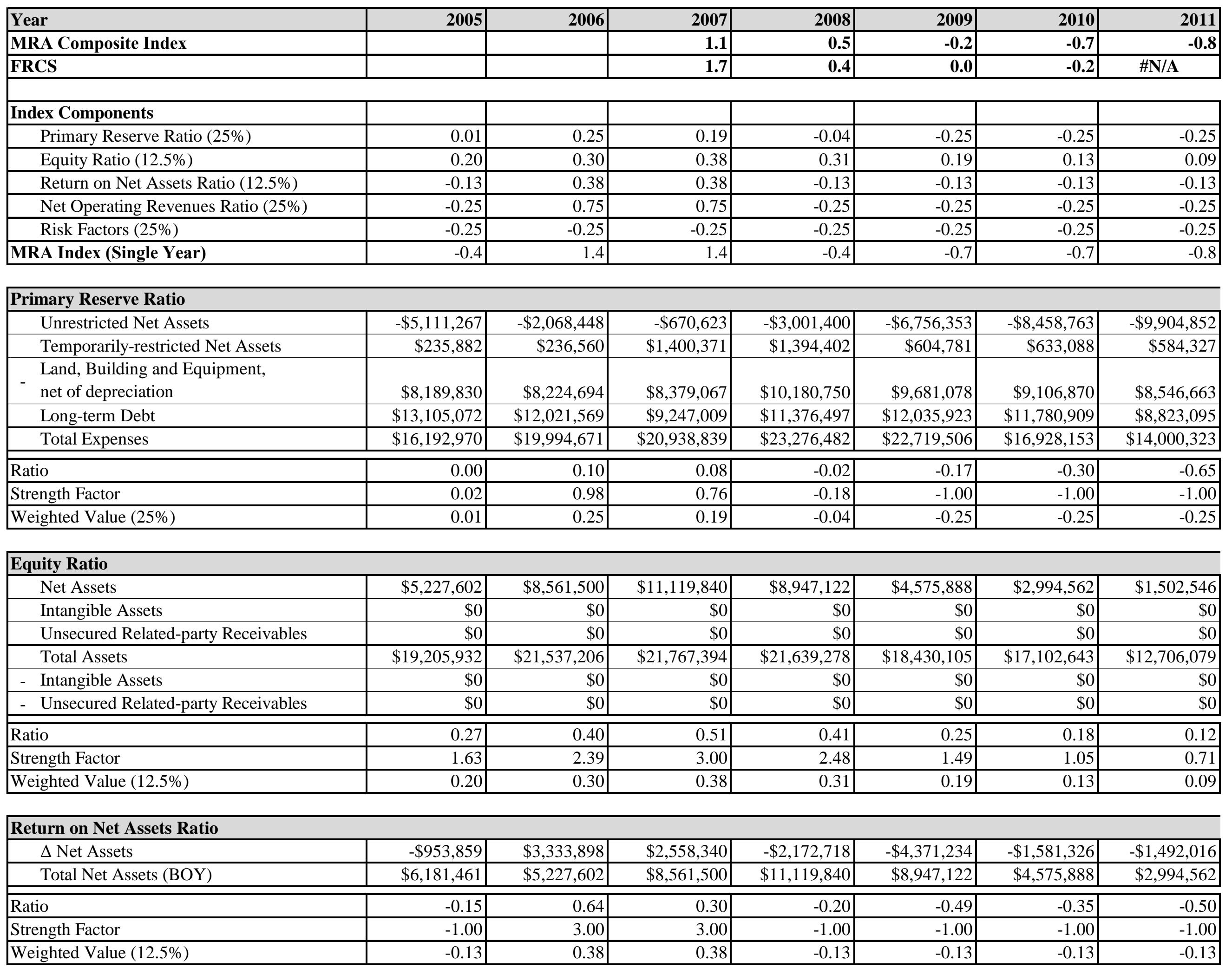

\begin{tabular}{|c|c|c|c|c|c|c|c|}
\hline \multicolumn{8}{|l|}{ Net Operating Revenues Ratio } \\
\hline$\Delta$ Unrestricted Net Assets & $-\$ 1,157,982$ & $\$ 3,042,819$ & $\$ 1,397,825$ & $-\$ 2,330,777$ & $-\$ 3,754,953$ & $-\$ 1,702,410$ & $-\$ 1,446,089$ \\
\hline Total Unrestricted Revenue & $\$ 12,866,973$ & $\$ 15,441,256$ & $\$ 16,026,391$ & $\$ 15,635,205$ & $\$ 15,907,978$ & $\$ 13,660,920$ & $\$ 10,184,708$ \\
\hline Ratio & -0.09 & 0.20 & 0.09 & -0.15 & -0.24 & -0.12 & -0.14 \\
\hline Strength Factor & -1.00 & 3.00 & 3.00 & -1.00 & -1.00 & -1.00 & -1.00 \\
\hline Weighted Value (25\%) & -0.25 & 0.75 & 0.75 & -0.25 & -0.25 & -0.25 & -0.25 \\
\hline \multicolumn{8}{|l|}{ Risk Factors } \\
\hline $\begin{array}{l}\text { Religious or Non-Degree Granting } \\
\text { yes }\end{array}$ & yes & yes & yes & yes & yes & yes & yes \\
\hline $\begin{array}{l}\text { Ratio of Full-time to Part-time Students } \\
<3.0\end{array}$ & no $\mathrm{P} / \mathrm{T}$ & no $\mathrm{P} / \mathrm{T}$ & no $\mathrm{P} / \mathrm{T}$ & no $\mathrm{P} / \mathrm{T}$ & no $\mathrm{P} / \mathrm{T}$ & no $\mathrm{P} / \mathrm{T}$ & 80.0 \\
\hline $\begin{array}{l}\text { Tuition Discounting } \\
>60 \%\end{array}$ & $44 \%$ & $61 \%$ & $63 \%$ & $66 \%$ & $61 \%$ & $55 \%$ & $55 \%$ \\
\hline $\begin{array}{l}\text { Interest Expense } \\
>10 \%\end{array}$ & $0 \%$ & $0 \%$ & $3 \%$ & $0 \%$ & $2 \%$ & $0 \%$ & $4 \%$ \\
\hline $\begin{array}{l}\text { Net Revenue } \\
<0\end{array}$ & $-\$ 953,859$ & $\$ 3,333,898$ & $\$ 2,558,340$ & $-\$ 2,172,718$ & $-\$ 4,371,234$ & $-\$ 1,581,326$ & $-\$ 1,449,322$ \\
\hline $\begin{array}{l}\text { Endowment/Total Budget } \\
<3.0\end{array}$ & 2.46 & 2.91 & 4.03 & 4.21 & 4.59 & 3.35 & 0.00 \\
\hline \begin{tabular}{|l} 
Total Risk Factors \\
\end{tabular} & 5 & 5 & 4 & 5 & 5 & 4 & 4 \\
\hline Strength Factor & -1 & -1 & -1 & -1 & -1 & -1 & -1 \\
\hline Weighted Value (25\%) & -0.25 & -0.25 & -0.25 & -0.25 & -0.25 & -0.25 & -0.25 \\
\hline
\end{tabular}


Mid-Continent University

\begin{tabular}{|c|c|c|c|c|c|c|c|c|c|}
\hline Year & 2005 & 2006 & 2007 & 2008 & 2009 & 2010 & 2011 & 2012 & 2013 \\
\hline MRA Composite Index & & & 2.0 & 2.2 & 2.3 & 2.3 & 2.3 & 2.2 & 2.0 \\
\hline FRCS & & & 3 & 3.0 & 3.0 & 3.0 & 3.0 & \#N/A & \#N/A \\
\hline \multicolumn{10}{|l|}{ Index Components } \\
\hline Primary Reserve Ratio (25\%) & 0.11 & 0.75 & 0.75 & 0.75 & 0.75 & 0.75 & 0.75 & 0.75 & 0.75 \\
\hline Equity Ratio (12.5\%) & 0.35 & 0.38 & 0.38 & 0.38 & 0.38 & 0.38 & 0.38 & 0.38 & 0.38 \\
\hline Return on Net Assets Ratio (12.5\%) & 0.38 & 0.38 & 0.38 & 0.38 & 0.38 & 0.38 & 0.38 & 0.36 & 0.29 \\
\hline Net Operating Revenues Ratio (25\%) & 0.60 & 0.75 & 0.75 & 0.75 & 0.75 & 0.75 & 0.75 & 0.75 & 0.37 \\
\hline Risk Factors (25\%) & -0.25 & -0.25 & 0.00 & 0.00 & 0.00 & 0.00 & 0.00 & 0.00 & 0.00 \\
\hline MRA Index (Single Year) & 1.2 & 2.0 & 2.3 & 2.3 & 2.3 & 2.3 & 2.3 & 2.2 & 1.8 \\
\hline \multicolumn{10}{|l|}{ Primary Reserve Ratio } \\
\hline Unrestricted Net Assets & $\$ 1,081,615$ & $\$ 3,034,492$ & $\$ 5,665,146$ & $\$ 8,176,395$ & $\$ 10,311,500$ & $\$ 12,696,038$ & $\$ 15,923,038$ & $\$ 16,898,172$ & $\$ 17,111,409$ \\
\hline Temporarily-restricted Net Assets & $\$ 0$ & $\$ 973,170$ & $\$ 698,201$ & $\$ 721,547$ & $\$ 777,517$ & $\$ 871,535$ & $\$ 984,138$ & $\$ 1,168,473$ & $\$ 1,442,918$ \\
\hline $\begin{array}{l}\text { Land, Building and Equipment, } \\
\text { net of depreciation }\end{array}$ & $\$ 5,304,959$ & $\$ 215,261$ & $\$ 427,140$ & $\$ 7,032,315$ & $\$ 7,880,894$ & $\$ 7,976,206$ & $\$ 8,852,589$ & $\$ 9,229,817$ & $\$ 9,015,038$ \\
\hline Long-term Debt & $\$ 4,512,901$ & $\$ 4,446,444$ & $\$ 4,255,042$ & $\$ 4,303,565$ & $\$ 3,998,658$ & $\$ 3,821,354$ & $\$ 3,674,187$ & $\$ 3,443,326$ & $\$ 3,263,394$ \\
\hline Total Expenses & $\$ 6,564,474$ & $\$ 8,264,048$ & $\$ 9,918,618$ & $\$ 13,158,041$ & $\$ 12,705,799$ & $\$ 14,816,700$ & $\$ 16,490,142$ & $\$ 21,974,087$ & $\$ 21,924,985$ \\
\hline Ratio & 0.04 & 1.00 & 1.03 & 0.47 & 0.57 & 0.64 & 0.71 & 0.54 & 0.56 \\
\hline Strength Factor & 0.44 & 3.00 & 3.00 & 3.00 & 3.00 & 3.00 & 3.00 & 3.00 & 3.00 \\
\hline Weighted Value (25\%) & 0.11 & 0.75 & 0.75 & 0.75 & 0.75 & 0.75 & 0.75 & 0.75 & 0.75 \\
\hline \multicolumn{10}{|l|}{ Equity Ratio } \\
\hline Net Assets & $\$ 5,001,102$ & $\$ 6,449,005$ & $\$ 8,999,429$ & $\$ 11,555,046$ & $\$ 13,430,367$ & $\$ 16,090,885$ & $\$ 19,785,281$ & $\$ 20,912,683$ & $\$ 21,867,838$ \\
\hline Intangible Assets & $\$ 0$ & $\$ 0$ & $\$ 0$ & $\$ 0$ & $\$ 0$ & $\$ 0$ & $\$ 0$ & $\$ 460,000$ & $\$ 460,000$ \\
\hline Unsecured Related-party Receivables & $\$ 0$ & $\$ 0$ & $\$ 0$ & $\$ 0$ & $\$ 0$ & $\$ 0$ & $\$ 0$ & $\$ 0$ & $\$ 0$ \\
\hline Total Assets & $\$ 10,648,851$ & $\$ 12,591,564$ & $\$ 15,361,103$ & $\$ 18,558,738$ & $\$ 20,488,453$ & $\$ 23,890,442$ & $\$ 28,094,608$ & $\$ 29,258,587$ & $\$ 30,628,699$ \\
\hline - Intangible Assets & $\$ 0$ & $\$ 0$ & $\$ 0$ & $\$ 0$ & $\$ 0$ & $\$ 0$ & $\$ 0$ & $\$ 460,000$ & $\$ 460,000$ \\
\hline - Unsecured Related-party Receivables & $\$ 0$ & $\$ 0$ & $\$ 0$ & $\$ 0$ & $\$ 0$ & $\$ 0$ & $\$ 0$ & $\$ 0$ & $\$ 0$ \\
\hline Ratio & 0.47 & 0.51 & 0.59 & 0.62 & 0.66 & 0.67 & 0.70 & 0.71 & 0.71 \\
\hline Strength Factor & 2.82 & 3.00 & 3.00 & 3.00 & 3.00 & 3.00 & 3.00 & 3.00 & 3.00 \\
\hline Weighted Value (12.5\%) & 0.35 & 0.38 & 0.38 & 0.38 & 0.38 & 0.38 & 0.38 & 0.38 & 0.38 \\
\hline \multicolumn{10}{|l|}{ Return on Net Assets Ratio } \\
\hline$\Delta$ Net Assets & $\$ 788,354$ & $\$ 1,447,903$ & $\$ 2,550,424$ & $\$ 2,555,617$ & $\$ 1,875,321$ & $\$ 2,660,518$ & $\$ 3,694,396$ & $\$ 1,127,402$ & $\$ 955,155$ \\
\hline Total Net Assets (BOY) & $\$ 4,212,748$ & $\$ 5,001,102$ & $\$ 6,449,005$ & $\$ 8,999,429$ & $\$ 11,555,046$ & $\$ 13,430,367$ & $\$ 16,090,885$ & $\$ 19,785,281$ & $\$ 20,912,683$ \\
\hline Ratio & 0.19 & 0.29 & 0.40 & 0.28 & 0.16 & 0.20 & 0.23 & 0.06 & 0.05 \\
\hline Strength Factor & 3.00 & 3.00 & 3.00 & 3.00 & 3.00 & 3.00 & 3.00 & 2.85 & 2.28 \\
\hline Weighted Value (12.5\%) & 0.38 & 0.38 & 0.38 & 0.38 & 0.38 & 0.38 & 0.38 & 0.36 & 0.29 \\
\hline \multicolumn{10}{|l|}{\begin{tabular}{|l|} 
Net Operating Revenues Ratio \\
\end{tabular}} \\
\hline$\Delta$ Unrestricted Net Assets & $\$ 192,607$ & $\$ 1,952,877$ & $\$ 2,630,654$ & $\$ 2,511,249$ & $\$ 2,135,105$ & $\$ 2,384,538$ & $\$ 3,227,000$ & $\$ 975,134$ & $\$ 213,237$ \\
\hline Total Unrestricted Revenue & $\$ 6,949,899$ & $\$ 9,266,774$ & $\$ 11,857,863$ & $\$ 15,433,819$ & $\$ 14,625,158$ & $\$ 16,886,190$ & $\$ 19,503,410$ & $\$ 22,798,330$ & $\$ 21,981,921$ \\
\hline Ratio & 0.03 & 0.21 & 0.22 & 0.16 & 0.15 & 0.14 & 0.17 & 0.04 & 0.01 \\
\hline Strength Factor & 2.39 & 3.00 & 3.00 & 3.00 & 3.00 & 3.00 & 3.00 & 3.00 & 1.49 \\
\hline Weighted Value (25\%) & 0.60 & 0.75 & 0.75 & 0.75 & 0.75 & 0.75 & 0.75 & 0.75 & 0.37 \\
\hline \multicolumn{10}{|l|}{ Risk Factors } \\
\hline $\begin{array}{l}\text { Enrollment } \\
<1,000(2) \text { or }<2,500(1)\end{array}$ & 759 & 860 & 1081 & 1414 & 1501 & 1673 & 2058 & 2224 & 2224 \\
\hline $\begin{array}{l}\text { Religious or Non-Degree Granting } \\
\text { yes }\end{array}$ & yes & yes & yes & yes & yes & yes & yes & yes & yes \\
\hline $\begin{array}{l}\text { Ratio of Full-time to Part-time Students } \\
<3.0\end{array}$ & 20.3 & 4.5 & 11.6 & 11.8 & 5.1 & 10.1 & 7.7 & 3.6 & no $\mathrm{P} / \mathrm{T}$ \\
\hline $\begin{array}{l}\text { Tuition Discounting } \\
>60 \%\end{array}$ & $8 \%$ & $10 \%$ & $9 \%$ & $9 \%$ & $10 \%$ & $9 \%$ & $9 \%$ & $13 \%$ & $13 \%$ \\
\hline $\begin{array}{l}\text { Tuition Reliance } \\
>85 \%\end{array}$ & $94 \%$ & $94 \%$ & $95 \%$ & $97 \%$ & $97 \%$ & $96 \%$ & $98 \%$ & $97 \%$ & $97 \%$ \\
\hline $\begin{array}{l}\text { Interest Expense } \\
>10 \%\end{array}$ & $4 \%$ & $3 \%$ & $3 \%$ & $2 \%$ & $2 \%$ & $1 \%$ & $1 \%$ & $1 \%$ & $1 \%$ \\
\hline $\begin{array}{l}\text { Net Revenue } \\
<0\end{array}$ & $\$ 695,142$ & $\$ 1,348,884$ & $\$ 2,327,627$ & $\$ 2,623,461$ & $\$ 2,244,758$ & $\$ 2,415,500$ & $\$ 3,285,689$ & $\$ 1,166,298$ & $\$ 710,825$ \\
\hline $\begin{array}{l}\text { Endowment/Total Budget } \\
<3.0\end{array}$ & 2.76 & 3.33 & 3.56 & 4.66 & 4.66 & 4.93 & 4.83 & 4.95 & 0.00 \\
\hline Total Risk Factors & 5 & 4 & 3 & 3 & 3 & 3 & 3 & 3 & 3 \\
\hline Strength Factor & -1 & -1 & 0 & 0 & 0 & 0 & 0 & 0 & 0 \\
\hline Weighted Value (25\%) & -0.25 & -0.25 & 0.00 & 0.00 & 0.00 & 0.00 & 0.00 & 0.00 & 0.00 \\
\hline
\end{tabular}


Virginia Intermont College

\begin{tabular}{|c|c|c|c|c|c|c|c|c|c|}
\hline Year & 2005 & 2006 & 2007 & 2008 & 2009 & 2010 & 2011 & 2012 & 2013 \\
\hline MRA Composite Index & & & 1.6 & 1.9 & 1.7 & 0.8 & 0.8 & 1.2 & 0.6 \\
\hline FRCS & & & 1.5 & 1.5 & 1.2 & 0.5 & 0.9 & 1.4 & 0.3 \\
\hline \multicolumn{10}{|l|}{\begin{tabular}{|l|} 
Index Components \\
\end{tabular}} \\
\hline Primary Reserve Ratio (25\%) & 0.39 & 0.29 & 0.62 & 0.41 & 0.44 & 0.25 & 0.11 & -0.12 & -0.13 \\
\hline Equity Ratio (12.5\%) & 0.27 & 0.25 & 0.32 & 0.38 & 0.38 & 0.35 & 0.36 & 0.38 & 0.27 \\
\hline Return on Net Assets Ratio (12.5\%) & 0.38 & -0.13 & 0.38 & 0.38 & -0.09 & -0.13 & 0.09 & 0.38 & -0.13 \\
\hline Net Operating Revenues Ratio (25\%) & 0.72 & -0.19 & 0.75 & 0.75 & 0.13 & -0.25 & 0.18 & 0.75 & -0.25 \\
\hline Risk Factors (25\%) & 0.50 & 0.00 & 0.25 & 0.25 & 0.25 & 0.00 & 0.25 & 0.25 & 0.00 \\
\hline MRA Index (Single Year) & 2.3 & 0.2 & 2.3 & 2.2 & 1.1 & 0.2 & 1.0 & 1.6 & -0.2 \\
\hline \multicolumn{10}{|l|}{ Primary Reserve Ratio } \\
\hline Unrestricted Net Assets & $\$ 1,267,186$ & $\$ 43,716$ & $\$ 1,397,580$ & $\$ 3,547,585$ & $\$ 3,339,613$ & $\$ 2,212,099$ & $\$ 2,062,928$ & $\$ 5,885,251$ & $\$ 385,060$ \\
\hline Temporarily-restricted Net Assets & $\$ 2,051,266$ & $\$ 2,438,373$ & $\$ 3,029,530$ & $\$ 1,974,015$ & $\$ 2,024,632$ & $\$ 1,134,801$ & $\$ 1,387,077$ & $\$ 1,402,931$ & $\$ 1,445,333$ \\
\hline $\begin{array}{l}\text { Land, Building and Equipment, } \\
\text { net of depreciation }\end{array}$ & $\$ 11,327,807$ & $\$ 11,964,280$ & $\$ 10,396,689$ & $\$ 10,109,881$ & $\$ 10,077,856$ & $\$ 9,521,237$ & $\$ 9,987,526$ & $\$ 15,653,245$ & $\$ 10,565,763$ \\
\hline Long-term Debt & $\$ 11,096,389$ & $\$ 11,865,145$ & $\$ 10,643,723$ & $\$ 7,055,607$ & $\$ 7,654,626$ & $\$ 7,873,100$ & $\$ 7,282,766$ & $\$ 7,550,059$ & $\$ 7,800,425$ \\
\hline Total Expenses & $\$ 19,901,991$ & $\$ 20,807,756$ & $\$ 18,784,943$ & $\$ 14,963,150$ & $\$ 16,821,778$ & $\$ 17,194,196$ & $\$ 16,875,334$ & $\$ 17,140,642$ & $\$ 17,543,146$ \\
\hline Ratio & 0.16 & 0.11 & 0.25 & 0.16 & 0.17 & 0.10 & 0.04 & \begin{tabular}{l|l|}
-0.05 \\
\end{tabular} & -0.05 \\
\hline Strength Factor & 1.55 & 1.15 & 2.49 & 1.65 & 1.75 & 0.99 & 0.44 & $\begin{array}{ll}-0.48 \\
\end{array}$ & -0.53 \\
\hline Weighted Value (25\%) & 0.39 & 0.29 & \begin{tabular}{l|l}
0.62 & -20 \\
\end{tabular} & 0.41 & 0.44 & 0.25 & 0.11 & \begin{tabular}{l|l|l|l|l|}
-0.12 \\
\end{tabular} & -0.13 \\
\hline
\end{tabular}

\begin{tabular}{|c|c|c|c|c|c|c|c|c|c|}
\hline \multicolumn{10}{|l|}{ Equity Ratio } \\
\hline Net Assets & $\$ 6,719,161$ & $\$ 6,156,869$ & $\$ 8,145,167$ & $\$ 9,470,377$ & $\$ 9,341,560$ & $\$ 7,332,845$ & $\$ 7,434,063$ & $\$ 11,265,973$ & $\$ 5,839,654$ \\
\hline Intangible Assets & $\$ 0$ & $\$ 0$ & $\$ 0$ & $\$ 0$ & $\$ 0$ & $\$ 0$ & $\$ 0$ & $\$ 0$ & $\$ 0$ \\
\hline Unsecured Related-party Receivables & $\$ 0$ & $\$ 0$ & $\$ 0$ & $\$ 0$ & $\$ 0$ & $\$ 0$ & $\$ 0$ & $\$ 0$ & $\$ 0$ \\
\hline Total Assets & $\$ 18,445,192$ & $\$ 18,766,662$ & $\$ 18,978,188$ & $\$ 16,940,187$ & $\begin{array}{l}17,404,388 \\
\end{array}$ & $\$ 15,524,233$ & $\$ 15,411,284$ & $\$ 20,288,323$ & $\$ 15,949,818$ \\
\hline - Intangible Assets & $\$ 0$ & $\$ 0$ & $\$ 0$ & $\$ 0$ & $\$ 0$ & $\$ 0$ & $\$ 0$ & $\$ 0$ & $\$ 0$ \\
\hline - Unsecured Related-party Receivables & $\$ 0$ & $\$ 0$ & $\$ 0$ & $\$ 0$ & $\$ 0$ & $\$ 0$ & $\$ 0$ & $\$ 0$ & $\$ 0$ \\
\hline \begin{tabular}{|l} 
Ratio \\
\end{tabular} & 0.36 & 0.33 & 0.43 & 0.56 & 0.54 & 0.47 & 0.48 & 0.56 & 0.37 \\
\hline Strength Factor & 2.19 & 1.97 & 2.58 & 3.00 & 3.00 & 2.83 & 2.89 & 3.00 & 2.20 \\
\hline Weighted Value (12.5\%) & 0.27 & 0.25 & 0.32 & \begin{tabular}{l|l|l}
0.38 \\
\end{tabular} & \begin{tabular}{l|l}
0.38 \\
\end{tabular} & 0.35 & 0.36 & 0.38 & 0.27 \\
\hline \multicolumn{10}{|l|}{\begin{tabular}{|l|} 
Return on Net Assets Ratio \\
\end{tabular}} \\
\hline$\Delta$ Net Assets & $\$ 622,382$ & $-\$ 562,292$ & $\$ 1,988,298$ & $\$ 1,325,210$ & $-\$ 128,817$ & $-\$ 2,008,715$ & $\$ 101,218$ & $\$ 3,831,910$ & $-\$ 5,426,319$ \\
\hline Total Net Assets (BOY) & $\$ 6,096,779$ & $\$ 6,719,161$ & $\$ 6,156,869$ & $\$ 8,145,167$ & $\$ 9,470,377$ & $\$ 9,341,560$ & $\$ 7,332,845$ & $\$ 7,434,063$ & $\$ 11,265,973$ \\
\hline Ratio & 0.10 & -0.08 & 0.32 & 0.16 & -0.01 & -0.22 & 0.01 & 0.52 & -0.48 \\
\hline Strength Factor & 3.00 & -1.00 & 3.00 & 3.00 & \begin{tabular}{l|l}
-0.68 \\
\end{tabular} & -1.00 & 0.69 & 3.00 & -1.00 \\
\hline Weighted Value (12.5\%) & 0.38 & -0.13 & 0.38 & \begin{tabular}{l|l|l}
0.38 \\
\end{tabular} & \begin{tabular}{l|l|l|l|}
-0.09 \\
\end{tabular} & -0.13 & 0.09 & 0.38 & -0.13 \\
\hline \multicolumn{10}{|l|}{\begin{tabular}{|l|} 
Net Operating Revenues Ratio \\
\end{tabular}} \\
\hline$\Delta$ Unrestricted Net Assets & $\$ 622,901$ & $-\$ 1,223,470$ & $\$ 1,353,864$ & $\$ 2,150,005$ & $-\$ 207,972$ & $-\$ 1,127,514$ & $-\$ 149,171$ & $\$ 3,822,323$ & $-\$ 5,500,191$ \\
\hline Total Unrestricted Revenue & $\$ 16,685,012$ & $\$ 17,515,597$ & $\$ 16,287,026$ & $\$ 11,515,174$ & $\$ 11,025,736$ & $\$ 13,037,364$ & $\$ 13,593,302$ & $\$ 12,821,565$ & $\$ 12,740,006$ \\
\hline Ratio & 0.04 & -0.07 & 0.08 & \begin{tabular}{l|l}
0.19 \\
\end{tabular} & \begin{tabular}{l|l}
-0.02 \\
\end{tabular} & \begin{tabular}{l|l|}
-0.09 \\
\end{tabular} & -0.01 & 0.30 & -0.43 \\
\hline Strength Factor & 2.87 & -0.75 & 3.00 & 3.00 & 0.53 & -1.00 & 0.73 & 3.00 & -1.00 \\
\hline Weighted Value (25\%) & 0.72 & -0.19 & 0.75 & 0.75 & \begin{tabular}{l|l|}
0.13 & \\
\end{tabular} & -0.25 & 0.18 & 0.75 & -0.25 \\
\hline \multicolumn{10}{|l|}{\begin{tabular}{|l} 
Risk Factors \\
\end{tabular}} \\
\hline $\begin{array}{l}\text { Enrollment } \\
<1,000(2) \text { or }<2,500(1)\end{array}$ & 1047 & 734 & 833 & 212 & 479 & 530 & 549 & 515 & 515 \\
\hline $\begin{array}{l}\text { Religious or Non-Degree Granting } \\
\text { yes }\end{array}$ & no & no & no & no & no & no & no & no & no \\
\hline $\begin{array}{l}\text { Ratio of Full-time to Part-time Students } \\
<3.0\end{array}$ & 16.3 & 8.8 & 8.1 & 6.9 & no $\mathrm{P} / \mathrm{T}$ & 31.5 & 132.0 & no $\mathrm{P} / \mathrm{T}$ & no $\mathrm{P} / \mathrm{T}$ \\
\hline $\begin{array}{l}\text { Tuition Discounting } \\
>60 \%\end{array}$ & $36 \%$ & $41 \%$ & $35 \%$ & $31 \%$ & $33 \%$ & $40 \%$ & $46 \%$ & $45 \%$ & $45 \%$ \\
\hline $\begin{array}{l}\text { Tuition Reliance } \\
>85 \%\end{array}$ & $69 \%$ & $78 \%$ & $62 \%$ & $55 \%$ & $47 \%$ & $73 \%$ & $62 \%$ & $40 \%$ & $40 \%$ \\
\hline $\begin{array}{l}\text { Interest Expense } \\
>10 \%\end{array}$ & $3 \%$ & $3 \%$ & $4 \%$ & $1 \%$ & $1 \%$ & $1 \%$ & $1 \%$ & $1 \%$ & $1 \%$ \\
\hline $\begin{array}{l}\text { Net Revenue } \\
<0\end{array}$ & $\$ 632,297$ & $-\$ 562,292$ & $\$ 1,988,298$ & $\$ 1,359,380$ & $\$ 1,033,365$ & $-\$ 2,041,787$ & $\$ 21,058$ & $\$ 3,844,163$ & $-\$ 2,431,703$ \\
\hline $\begin{array}{l}\text { Endowment/Total Budget } \\
<3.0\end{array}$ & 14.79 & 15.84 & 14.34 & 8.54 & 8.76 & 12.61 & 11.75 & 12.85 & 13.15 \\
\hline Total Risk Factors & 1 & 3 & 2 & 2 & $2 \mid$ & 3 & 2 & 2 & 3 \\
\hline Strength Factor & 2 & 0 & 1 & 1 & 1 & 0 & 1 & 1 & 0 \\
\hline Weighted Value (25\%) & 0.50 & 0.00 & 0.25 & 0.25 & \begin{tabular}{l|l}
0.25 \\
\end{tabular} & 0.00 & 0.25 & 0.25 & 0.00 \\
\hline
\end{tabular}




\section{Bethany College}

\begin{tabular}{|c|c|c|c|c|c|c|c|c|}
\hline Year & 2005 & 2006 & 2007 & 2008 & 2009 & 2010 & 2011 & 2012 \\
\hline MRA Composite Index & & & 0.1 & $\mathbf{0 . 0}$ & 0.1 & 0.2 & 0.1 & $\mathbf{0 . 4}$ \\
\hline FRCS & & & 0.6 & 1.1 & 0.6 & 0.6 & 0.7 & $\mathbf{0 . 6}$ \\
\hline \multicolumn{9}{|l|}{ Index Components } \\
\hline Primary Reserve Ratio (25\%) & 0.68 & 0.31 & 0.36 & 0.75 & 0.36 & 0.47 & 0.69 & 0.75 \\
\hline Equity Ratio (12.5\%) & 0.25 & 0.24 & 0.07 & -0.05 & -0.10 & -0.13 & -0.13 & -0.13 \\
\hline Return on Net Assets Ratio (12.5\%) & 0.00 & -0.13 & -0.13 & -0.13 & 0.38 & 0.38 & -0.13 & 0.32 \\
\hline Net Operating Revenues Ratio (25\%) & 0.01 & -0.25 & 0.01 & -0.25 & -0.25 & -0.25 & -0.25 & 0.11 \\
\hline Risk Factors $(25 \%)$ & -0.25 & -0.25 & -0.25 & -0.25 & -0.25 & -0.25 & -0.25 & -0.25 \\
\hline MRA Index (Single Year) & 0.7 & -0.1 & 0.1 & 0.1 & 0.1 & 0.2 & -0.1 & 0.8 \\
\hline \multicolumn{9}{|l|}{ Primary Reserve Ratio } \\
\hline Unrestricted Net Assets & $\$ 2,448,451$ & $\$ 96,470$ & $-\$ 296,121$ & $-\$ 2,683,752$ & $-\$ 4,128,721$ & $-\$ 6,243,103$ & $-\$ 7,405,107$ & $-\$ 7,737,710$ \\
\hline Temporarily-restricted Net Assets & $\$ 913,166$ & $\$ 1,081,451$ & $\$ 1,106,959$ & $\$ 1,428,932$ & $\$ 1,797,204$ & $\$ 2,040,837$ & $\$ 3,452,221$ & $\$ 3,584,996$ \\
\hline $\begin{array}{l}\text { Land, Building and Equipment, } \\
\text { net of depreciation }\end{array}$ & $\$ 6,273,419$ & $\$ 5,970,877$ & $\$ 6,304,363$ & $\$ 9,296,543$ & $\$ 12,830,603$ & $\$ 12,398,066$ & $\$ 11,779,568$ & $\$ 11,242,246$ \\
\hline Long-term Debt & $\$ 6,838,064$ & $\$ 6,656,617$ & $\$ 7,743,197$ & $\$ 16,172,383$ & $\$ 17,850,796$ & $\$ 19,939,299$ & $\$ 20,659,567$ & $\$ 20,977,293$ \\
\hline Total Expenses & $\$ 14,445,270$ & $\$ 15,132,193$ & $\$ 15,776,030$ & $\$ 17,649,058$ & $\$ 18,548,265$ & $\$ 17,762,058$ & $\$ 17,780,898$ & $\$ 18,290,127$ \\
\hline Ratio & 0.27 & 0.12 & 0.14 & 0.32 & 0.14 & 0.19 & 0.28 & 0.31 \\
\hline Strength Factor & 2.72 & 1.23 & 1.43 & 3.00 & 1.45 & 1.88 & 2.77 & 3.00 \\
\hline Weighted Value (25\%) & 0.68 & 0.31 & 0.36 & 0.75 & 0.36 & 0.47 & 0.69 & 0.75 \\
\hline
\end{tabular}

\begin{tabular}{|c|c|c|c|c|c|c|c|c|}
\hline \multicolumn{9}{|l|}{ Equity Ratio } \\
\hline Net Assets & $\$ 3,876,345$ & $\$ 3,450,572$ & $\$ 928,593$ & $-\$ 1,125,340$ & $-\$ 2,206,721$ & $-\$ 4,084,964$ & $-\$ 3,836,973$ & $-\$ 4,034,311$ \\
\hline Intangible Assets & $\$ 0$ & $\$ 0$ & $\$ 0$ & $\$ 0$ & $\$ 0$ & $\$ 0$ & $\$ 0$ & $\$ 0$ \\
\hline Unsecured Related-party Receivables & $\$ 0$ & $\$ 0$ & $\$ 0$ & $\$ 0$ & $\$ 0$ & $\$ 0$ & $\$ 0$ & $\$ 0$ \\
\hline Total Assets & $\$ 11,412,751$ & $\$ 10,776,833$ & $\$ 9,548,363$ & $\$ 16,666,187$ & $\$ 16,705,860$ & $\$ 16,623,196$ & $\$ 17,658,514$ & $\$ 17,903,689$ \\
\hline - Intangible Assets & $\$ 0$ & $\$ 0$ & $\$ 0$ & $\$ 0$ & $\$ 0$ & $\$ 0$ & $\$ 0$ & $\$ 0$ \\
\hline - Unsecured Related-party Receivables & $\$ 0$ & $\$ 0$ & $\$ 0$ & $\$ 0$ & $\$ 0$ & $\$ 0$ & $\$ 0$ & $\$ 0$ \\
\hline Ratio & 0.34 & 0.32 & 0.10 & \begin{tabular}{l|l|}
-0.07 \\
\end{tabular} & \begin{tabular}{l|l|}
-0.13 \\
\end{tabular} & -0.25 & -0.22 & -0.23 \\
\hline Strength Factor & 2.04 & 1.92 & 0.58 & -0.41 & -0.79 & -1.00 & -1.00 & -1.00 \\
\hline Weighted Value (12.5\%) & 0.25 & 0.24 & 0.07 & \begin{tabular}{l|l}
-0.05 \\
\end{tabular} & -0.10 & -0.13 & -0.13 & -0.13 \\
\hline
\end{tabular}

\begin{tabular}{|c|c|c|c|c|c|c|c|c|}
\hline \multicolumn{9}{|l|}{ Return on Net Assets Ratio } \\
\hline$\Delta$ Net Assets & $\$ 0$ & $-\$ 425,773$ & $-\$ 2,521,979$ & $-\$ 2,053,933$ & $-\$ 1,081,381$ & $-\$ 1,878,243$ & $\$ 247,991$ & $-\$ 197,338$ \\
\hline Total Net Assets (BOY) & $\$ 3,876,345$ & $\$ 3,876,345$ & $\$ 3,450,572$ & $\$ 928,593$ & $-\$ 1,125,340$ & $-\$ 2,206,721$ & $-\$ 4,084,964$ & $-\$ 3,836,973$ \\
\hline Ratio & 0.00 & -0.11 & -0.73 & -2.21 & 0.96 & 0.85 & -0.06 & 0.05 \\
\hline Strength Factor & 0.00 & -1.00 & -1.00 & -1.00 & 3.00 & 3.00 & -1.00 & 2.57 \\
\hline Weighted Value (12.5\%) & 0.00 & -0.13 & -0.13 & -0.13 & 0.38 & 0.38 & -0.13 & 0.32 \\
\hline
\end{tabular}

\begin{tabular}{|l|r|r|r|r|r|r|r|r|}
\hline \multicolumn{10}{|l|}{ Net Operating Revenues Ratio } \\
\hline$\Delta$ Unrestricted Net Assets & $-\$ 409,776$ & $-\$ 2,351,981$ & $-\$ 392,591$ & $-\$ 2,387,631$ & $-\$ 1,444,969$ & $-\$ 2,114,382$ & $-\$ 1,162,004$ & $-\$ 332,603$ \\
\hline Total Unrestricted Revenue & $\$ 10,643,131$ & $\$ 10,639,463$ & $\$ 10,163,052$ & $\$ 11,016,813$ & $\$ 12,466,309$ & $\$ 12,836,478$ & $\$ 14,108,121$ & $\$ 15,073,065$ \\
\hline \hline Ratio & -0.04 & -0.22 & -0.04 & -0.22 & -0.12 & -0.16 & -0.08 & -0.02 \\
\hline Strength Factor & 0.04 & -1.00 & 0.03 & -1.00 & -1.00 & -1.00 & -1.00 & 0.45 \\
\hline Weighted Value (25\%) & 0.01 & -0.25 & 0.01 & -0.25 & -0.25 & -0.25 & -0.25 & 0.11 \\
\hline
\end{tabular}

\begin{tabular}{|c|c|c|c|c|c|c|c|c|}
\hline \multicolumn{9}{|l|}{\begin{tabular}{|l} 
Risk Factors \\
\end{tabular}} \\
\hline $\begin{array}{l}\text { Enrollment } \\
<1,000(2) \text { or }<2,500(1)\end{array}$ & 570 & 566 & 527 & 522 & 568 & 581 & 597 & 599 \\
\hline $\begin{array}{l}\text { Religious or Non-Degree Granting } \\
\text { yes }\end{array}$ & yes & yes & yes & yes & yes & yes & yes & yes \\
\hline $\begin{array}{l}\text { Ratio of Full-time to Part-time Students } \\
<3.0\end{array}$ & 153.0 & no $P / T$ & 167.0 & 77.6 & 88.0 & no $P / T$ & no $P / T$ & no $P / T$ \\
\hline $\begin{array}{l}\text { Tuition Discounting } \\
>60 \%\end{array}$ & $38 \%$ & $37 \%$ & $37 \%$ & $40 \%$ & $45 \%$ & $45 \%$ & $44 \%$ & $42 \%$ \\
\hline $\begin{array}{l}\text { Tuition Reliance } \\
>85 \%\end{array}$ & $60 \%$ & $61 \%$ & $62 \%$ & $56 \%$ & $55 \%$ & $71 \%$ & $63 \%$ & $78 \%$ \\
\hline $\begin{array}{l}\text { Interest Expense } \\
>10 \%\end{array}$ & $0 \%$ & $0 \%$ & $0 \%$ & $1 \%$ & $1 \%$ & $2 \%$ & $2 \%$ & $2 \%$ \\
\hline $\begin{array}{l}\text { Net Revenue } \\
<0\end{array}$ & $-\$ 1,569,437$ & $-\$ 1,852,320$ & $-\$ 2,846,461$ & $-\$ 3,258,973$ & $-\$ 1,984,254$ & $-\$ 2,889,681$ & $-\$ 591,079$ & $-\$ 312,201$ \\
\hline $\begin{array}{l}\text { Endowment/Total Budget } \\
<3.0\end{array}$ & 0.81 & 0.78 & 0.79 & 1.01 & 1.47 & 1.71 & 1.63 & 1.61 \\
\hline Total Risk Factors & 5 & 5 & 5 & 5 & 5 & 5 & 5 & 5 \\
\hline Strength Factor & -1 & -1 & -1 & -1 & -1 & $-1 \mid$ & -1 & -1 \\
\hline Weighted Value (25\%) & -0.25 & -0.25 & -0.25 & -0.25 & -0.25 & -0.25 & -0.25 & -0.25 \\
\hline
\end{tabular}


Birmingham Southern College

\begin{tabular}{|c|c|c|c|c|c|c|c|c|c|}
\hline Year & 2005 & 2006 & 2007 & 2008 & 2009 & 2010 & 2011 & 2012 & 2013 \\
\hline MRA Composite Index & & & 1.1 & 0.8 & 0.6 & 0.2 & 0.7 & 1.3 & 2.2 \\
\hline FRCS & & & 2.2 & 2.2 & 0.6 & 0.6 & 0.9 & 2.4 & 3.0 \\
\hline \multicolumn{10}{|l|}{ Index Components } \\
\hline Primary Reserve Ratio (25\%) & 0.75 & 0.75 & 0.75 & 0.75 & 0.36 & -0.05 & 0.10 & 0.75 & 0.75 \\
\hline Equity Ratio (12.5\%) & 0.38 & 0.38 & 0.38 & 0.38 & 0.38 & 0.38 & 0.38 & \begin{tabular}{l|l}
0.38 \\
\end{tabular} & 0.38 \\
\hline Return on Net Assets Ratio (12.5\%) & -0.03 & 0.00 & 0.08 & -0.13 & -0.13 & -0.13 & -0.11 & -0.13 & 0.38 \\
\hline Net Operating Revenues Ratio (25\%) & 0.64 & -0.25 & -0.25 & -0.25 & -0.25 & -0.25 & 0.75 & 0.75 & 0.75 \\
\hline Risk Factors (25\%) & 0.00 & 0.00 & 0.00 & 0.00 & 0.00 & 0.00 & 0.25 & 0.00 & 0.50 \\
\hline MRA Index (Single Year) & 1.7 & 0.9 & 1.0 & 0.8 & 0.4 & 0.0 & 1.4 & 1.8 & 2.8 \\
\hline \multicolumn{10}{|l|}{ Primary Reserve Ratio } \\
\hline Unrestricted Net Assets & $\$ 91,782,421$ & $\$ 83,795,962$ & $\$ 71,407,867$ & $\$ 62,243,272$ & $\$ 36,778,001$ & $\$ 18,317,547$ & $\$ 20,709,580$ & $\$ 42,664,843$ & $\$ 45,904,363$ \\
\hline Temporarily-restricted Net Assets & $\$ 34,261,336$ & $\$ 41,384,009$ & $\$ 49,503,918$ & $\$ 35,731,511$ & $\$ 16,532,437$ & $\$ 16,287,366$ & $\$ 18,345,814$ & $\$ 12,997,241$ & $\$ 17,254,474$ \\
\hline $\begin{array}{l}\text { Land, Building and Equipment, } \\
\text { net of depreciation }\end{array}$ & $\$ 99,814,244$ & $\$ 98,895,661$ & $\$ 109,283,682$ & $\$ 111,894,660$ & $\$ 111,322,800$ & $\$ 116,991,214$ & $\$ 115,332,275$ & $\$ 112,261,874$ & $\$ 109,405,775$ \\
\hline Long-term Debt & $\$ 51,659,715$ & $\$ 55,266,407$ & $\$ 63,249,937$ & $\$ 65,320,052$ & $\$ 68,782,988$ & $\$ 80,947,559$ & $\$ 79,336,806$ & $\$ 78,104,729$ & $\$ 75,371,971$ \\
\hline Total Expenses & $\$ 60,108,806$ & $\$ 63,561,208$ & $\$ 64,620,793$ & $\$ 68,876,570$ & $\$ 74,757,558$ & $\$ 79,258,704$ & $\$ 75,285,913$ & $\$ 66,974,206$ & $\$ 65,989,114$ \\
\hline Ratio & 1.30 & 1.28 & 1.16 & 0.75 & 0.14 & -0.02 & 0.04 & 0.32 & 0.44 \\
\hline Strength Factor & 3.00 & 3.00 & 3.00 & 3.00 & 1.44 & -0.18 & 0.41 & 3.00 & 3.00 \\
\hline Weighted Value (25\%) & 0.75 & 0.75 & 0.75 & 0.75 & 0.36 & -0.05 & 0.10 & 0.75 & 0.75 \\
\hline \multicolumn{10}{|l|}{ Equity Ratio } \\
\hline Net Assets & $\$ 191,410,785$ & $\$ 191,302,034$ & $\$ 193,786,186$ & $\$ 174,778,229$ & $\$ 132,742,770$ & $\$ 119,517,647$ & $\$ 117,403,174$ & $\$ 110,174,403$ & $\$ 119,526,342$ \\
\hline Intangible Assets & $\$ 0$ & $\$ 0$ & $\$ 0$ & $\$ 0$ & $\$ 0$ & $\$ 0$ & $\$ 0$ & $\$ 0$ & $\$ 0$ \\
\hline Unsecured Related-party Receivables & $\$ 0$ & $\$ 0$ & $\$ 0$ & $\$ 0$ & $\$ 0$ & $\$ 0$ & $\$ 0$ & $\$ 0$ & $\$ 0$ \\
\hline Total Assets & $\$ 247,585,056$ & $\$ 252,251,854$ & $\$ 263,811,814$ & $\$ 244,773,436$ & $\$ 206,321,940$ & $\$ 207,964,972$ & $\$ 200,893,319$ & $\$ 189,448,079$ & $\$ 196,115,011$ \\
\hline - Intangible Assets & $\$ 0$ & $\$ 0$ & $\$ 0$ & $\$ 0$ & $\$ 0$ & $\$ 0$ & $\$ 0$ & $\$ 0$ & $\$ 0$ \\
\hline - Unsecured Related-party Receivables & $\$ 0$ & $\$ 0$ & $\$ 0$ & $\$ 0$ & $\$ 0$ & $\$ 0$ & $\$ 0$ & $\$ 0$ & $\$ 0$ \\
\hline Ratio & 0.77 & 0.76 & 0.73 & 0.71 & 0.64 & 0.57 & 0.58 & 0.58 & 0.61 \\
\hline Strength Factor & 3.00 & 3.00 & 3.00 & 3.00 & 3.00 & 3.00 & 3.00 & 3.00 & 3.00 \\
\hline Weighted Value (12.5\%) & 0.38 & 0.38 & 0.38 & 0.38 & 0.38 & 0.38 & 0.38 & 0.38 & 0.38 \\
\hline \multicolumn{10}{|l|}{ Return on Net Assets Ratio } \\
\hline$\Delta$ Net Assets & $-\$ 1,064,316$ & $-\$ 108,751$ & $\$ 2,484,152$ & $-\$ 19,007,957$ & $-\$ 42,035,459$ & $-\$ 13,225,123$ & $-\$ 2,114,473$ & $-\$ 7,228,771$ & $\$ 9,351,939$ \\
\hline Total Net Assets (BOY) & $\$ 192,475,101$ & $\$ 191,410,785$ & $\$ 191,302,034$ & $\$ 193,786,186$ & $\$ 174,778,229$ & $\$ 132,742,770$ & $\$ 119,517,647$ & $\$ 117,403,174$ & $\$ 110,174,403$ \\
\hline Ratio & -0.01 & 0.00 & 0.01 & -0.10 & -0.24 & -0.10 & \begin{tabular}{ll|}
-0.02 \\
\end{tabular} & 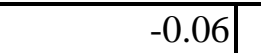 & 0.08 \\
\hline Strength Factor & -0.28 & -0.03 & 0.65 & -1.00 & -1.00 & -1.00 & -0.88 & -1.00 & 3.00 \\
\hline Weighted Value (12.5\%) & -0.03 & 0.00 & 0.08 & -0.13 & -0.13 & -0.13 & -0.11 & \begin{tabular}{|c|c|c|}
-0.13 \\
\end{tabular} & 0.38 \\
\hline \multicolumn{10}{|l|}{\begin{tabular}{|l} 
Net Operating Revenues Ratio \\
\end{tabular}} \\
\hline$\Delta$ Unrestricted Net Assets & $\$ 1,081,846$ & $-\$ 7,986,459$ & $-\$ 12,388,095$ & $-\$ 9,164,595$ & $-\$ 25,465,271$ & $-\$ 18,460,454$ & $\$ 2,392,033$ & $\$ 21,955,263$ & $\$ 3,239,520$ \\
\hline Total Unrestricted Revenue & $\$ 34,561,667$ & $\$ 35,038,938$ & $\$ 33,765,643$ & $\$ 39,431,722$ & $\$ 45,215,251$ & $\$ 49,497,975$ & $\$ 56,844,507$ & $\$ 52,903,744$ & $\$ 51,007,611$ \\
\hline Ratio & 0.03 & -0.23 & -0.37 & -0.23 & -0.56 & -0.37 & 0.04 & \begin{tabular}{l|l}
0.42 \\
\end{tabular} & 0.06 \\
\hline Strength Factor & 2.57 & -1.00 & -1.00 & -1.00 & -1.00 & -1.00 & 3.00 & 3.00 & 3.00 \\
\hline Weighted Value $(25 \%)$ & 0.64 & -0.25 & -0.25 & -0.25 & -0.25 & -0.25 & 0.75 & 0.75 & 0.75 \\
\hline \multicolumn{10}{|l|}{ Risk Factors } \\
\hline $\begin{array}{l}\text { Enrollment } \\
<1,000(2) \text { or }<2,500(1)\end{array}$ & 1409 & 1361 & 1230 & 1354 & 1428 & 1514 & 1528 & 1299 & 1299 \\
\hline $\begin{array}{l}\text { Religious or Non-Degree Granting } \\
\text { yes }\end{array}$ & no & no & no & no & no & no & no & no & no \\
\hline $\begin{array}{l}\text { Ratio of Full-time to Part-time Students } \\
<3.0\end{array}$ & no $P / T$ & no $P / T$ & no $P / T$ & no $\mathrm{P} / \mathrm{T}$ & no $\mathrm{P} / \mathrm{T}$ & no $P / T$ & no $P / T$ & no $\mathrm{P} / \mathrm{T}$ & no $\mathrm{P} / \mathrm{T}$ \\
\hline $\begin{array}{l}\text { Tuition Discounting } \\
>60 \% \\
\end{array}$ & $51 \%$ & $54 \%$ & $47 \%$ & $49 \%$ & $56 \%$ & $57 \%$ & $54 \%$ & $56 \%$ & $56 \%$ \\
\hline $\begin{array}{l}\text { Tuition Reliance } \\
>85 \%\end{array}$ & $59 \%$ & $48 \%$ & $47 \%$ & $62 \%$ & $66 \%$ & $67 \%$ & $65 \%$ & $64 \%$ & $64 \%$ \\
\hline $\begin{array}{l}\text { Interest Expense } \\
>10 \%\end{array}$ & $4 \%$ & $4 \%$ & $5 \%$ & $5 \%$ & $4 \%$ & $5 \%$ & $5 \%$ & $5 \%$ & $4 \%$ \\
\hline $\begin{array}{l}\text { Net Revenue } \\
<0\end{array}$ & $-\$ 4,652,765$ & $-\$ 11,475,895$ & $-\$ 11,516,051$ & $-\$ 18,808,993$ & $-\$ 22,110,084$ & $-\$ 19,000,783$ & $\$ 173,835$ & $-\$ 4,690,020$ & $\$ 7,862,250$ \\
\hline $\begin{array}{l}\text { Endowment/Total Budget } \\
<3.0\end{array}$ & 0.49 & 0.52 & 0.56 & 0.68 & 1.13 & 1.40 & 1.44 & 1.42 & 0.00 \\
\hline Total Risk Factors & 3 & 3 & 3 & 3 & 3 & 3 & 2 & 3 & 1 \\
\hline Strength Factor & 0 & 0 & 0 & 0 & 0 & 0 & 1 & 0 & 2 \\
\hline Weighted Value (25\%) & 0.00 & 0.00 & 0.00 & 0.00 & 0.00 & 0.00 & 0.25 & 0.00 & 0.50 \\
\hline
\end{tabular}


Brevard College

\begin{tabular}{|c|c|c|c|c|c|c|c|c|c|}
\hline Year & 2005 & 2006 & 2007 & 2008 & 2009 & 2010 & 2011 & 2012 & 2013 \\
\hline MRA Composite Index & & & 1.4 & 0.8 & 0.1 & 0.4 & 0.6 & 0.4 & 0.9 \\
\hline FRCS & & & 2.4 & 1.3 & 0.6 & 1.4 & 1.1 & 0.8 & 2.5 \\
\hline \multicolumn{10}{|l|}{\begin{tabular}{|l|} 
Index Components \\
\end{tabular}} \\
\hline Primary Reserve Ratio (25\%) & 0.54 & -0.25 & 0.75 & 0.42 & -0.23 & -0.15 & -0.02 & -0.13 & 0.43 \\
\hline Equity Ratio (12.5\%) & 0.38 & 0.38 & 0.38 & 0.38 & 0.38 & 0.38 & 0.38 & 0.38 & 0.38 \\
\hline Return on Net Assets Ratio (12.5\%) & 0.38 & 0.38 & -0.13 & -0.13 & -0.13 & 0.38 & 0.32 & -0.13 & 0.38 \\
\hline Net Operating Revenues Ratio (25\%) & 0.75 & 0.75 & 0.75 & -0.25 & -0.25 & 0.75 & 0.30 & -0.01 & 0.75 \\
\hline Risk Factors (25\%) & -0.25 & -0.25 & -0.25 & -0.25 & -0.25 & -0.25 & -0.25 & -0.25 & -0.25 \\
\hline MRA Index (Single Year) & 1.8 & 1.0 & 1.5 & 0.2 & -0.5 & 1.1 & 0.7 & -0.1 & 1.7 \\
\hline \multicolumn{10}{|l|}{ Primary Reserve Ratio } \\
\hline Unrestricted Net Assets & $\$ 14,141,699$ & $\$ 15,536,192$ & $\$ 17,101,024$ & $\$ 14,971,441$ & $\$ 7,214,908$ & $\$ 7,919,308$ & $\$ 7,985,476$ & $\$ 7,226,109$ & $\$ 10,682,188$ \\
\hline Temporarily-restricted Net Assets & $\$ 2,143,491$ & $\$ 1,906,672$ & $\$ 1,883,214$ & $\$ 1,308,302$ & $\$ 2,304,629$ & $\$ 1,966,953$ & $\$ 2,882,739$ & $\$ 2,178,043$ & $\$ 3,447,414$ \\
\hline $\begin{array}{l}\text { Land, Building and Equipment, } \\
\text { net of depreciation }\end{array}$ & $\$ 27,121,766$ & $\$ 28,787,002$ & $\$ 28,234,661$ & $\$ 27,740,341$ & $\$ 27,345,825$ & $\$ 27,090,077$ & $\$ 26,300,317$ & $\$ 25,295,777$ & $\$ 24,322,319$ \\
\hline Long-term Debt & $\$ 14,821,807$ & $-\$ 1,540,406$ & $\$ 15,038,351$ & $\$ 15,488,495$ & $\$ 15,702,792$ & $\$ 15,797,045$ & $\$ 15,264,111$ & $\$ 14,705,742$ & $\$ 14,029,618$ \\
\hline Total Expenses & $\$ 18,570,766$ & $\$ 19,136,396$ & $\$ 2,220,733$ & $\$ 23,728,197$ & $\$ 22,708,606$ & $\$ 22,850,886$ & $\$ 22,513,909$ & $\$ 22,035,459$ & $\$ 22,434,669$ \\
\hline Ratio & 0.21 & \begin{tabular}{|c|}
-0.67 \\
\end{tabular} & 2.61 & 0.17 & \begin{tabular}{l|l|}
-0.09 \\
\end{tabular} & \begin{tabular}{l|l|}
-0.06 \\
\end{tabular} & \begin{tabular}{l|l|}
-0.01 \\
\end{tabular} & \begin{tabular}{l|l|}
-0.05 \\
\end{tabular} & 0.17 \\
\hline Strength Factor & 2.15 & -1.00 & 3.00 & 1.70 & -0.94 & -0.62 & -0.07 & -0.54 & 1.71 \\
\hline Weighted Value $(25 \%)$ & 0.54 & -0.25 & 0.75 & 0.42 & -0.23 & -0.15 & \begin{tabular}{ll|l}
-0.02 \\
\end{tabular} & -0.13 & 0.43 \\
\hline \multicolumn{10}{|l|}{ Equity Ratio } \\
\hline Net Assets & $\$ 36,445,004$ & $\$ 54,410,030$ & $\$ 39,898,674$ & $\$ 38,301,498$ & $\$ 29,818,049$ & $\$ 32,159,283$ & $\$ 33,782,675$ & $\$ 32,317,148$ & $\$ 37,351,233$ \\
\hline Intangible Assets & $\$ 0$ & $\$ 0$ & $\$ 0$ & $\$ 0$ & $\$ 0$ & $\$ 0$ & $\$ 0$ & $\$ 0$ & $\$ 0$ \\
\hline Unsecured Related-party Receivables & $\$ 0$ & $\$ 0$ & $\$ 0$ & $\$ 0$ & $\$ 0$ & $\$ 0$ & $\$ 0$ & $\$ 0$ & $\$ 0$ \\
\hline Total Assets & $\$ 54,066,739$ & $\$ 56,213,641$ & $\$ 58,271,094$ & $\$ 56,333,288$ & $\$ 47,954,402$ & $\$ 50,607,663$ & $\$ 51,778,137$ & $\$ 48,992,688$ & $\$ 53,383,277$ \\
\hline - Intangible Assets & $\$ 0$ & $\$ 0$ & $\$ 0$ & $\$ 0$ & $\$ 0$ & $\$ 0$ & $\$ 0$ & $\$ 0$ & $\$ 0$ \\
\hline - Unsecured Related-party Receivables & $\$ 0$ & $\$ 0$ & $\$ 0$ & $\$ 0$ & $\$ 0$ & $\$ 0$ & $\$ 0$ & $\$ 0$ & $\$ 0$ \\
\hline Ratio & 0.67 & 0.97 & 0.68 & 0.68 & 0.62 & 0.64 & 0.65 & 0.66 & 0.70 \\
\hline Strength Factor & 3.00 & 3.00 & 3.00 & 3.00 & 3.00 & 3.00 & 3.00 & 3.00 & 3.00 \\
\hline Weighted Value (12.5\%) & 0.38 & 0.38 & 0.38 & 0.38 & 0.38 & 0.38 & 0.38 & 0.38 & 0.38 \\
\hline \multicolumn{10}{|l|}{\begin{tabular}{|l|} 
Return on Net Assets Ratio \\
\end{tabular}} \\
\hline$\Delta$ Net Assets & $\$ 2,314,697$ & $\$ 17,965,026$ & $-\$ 14,511,356$ & $-\$ 1,597,176$ & $-\$ 8,483,449$ & $\$ 2,341,234$ & $\$ 1,623,392$ & $-\$ 1,465,527$ & $\$ 5,034,085$ \\
\hline Total Net Assets (BOY) & $\$ 34,130,307$ & $\$ 36,445,004$ & $\$ 54,410,030$ & $\$ 39,898,674$ & $\$ 38,301,498$ & $\$ 29,818,049$ & $\$ 32,159,283$ & $\$ 33,782,675$ & $\$ 32,317,148$ \\
\hline Ratio & 0.07 & 0.49 & -0.27 & -0.04 & -0.22 & 0.08 & 0.05 & -0.04 & 0.16 \\
\hline Strength Factor & 3.00 & 3.00 & -1.00 & -1.00 & -1.00 & 3.00 & 2.52 & -1.00 & 3.00 \\
\hline Weighted Value (12.5\%) & 0.38 & 0.38 & -0.13 & -0.13 & -0.13 & 0.38 & \begin{tabular}{l|l}
0.32 \\
\end{tabular} & \begin{tabular}{|c|}
-0.13 \\
\end{tabular} & 0.38 \\
\hline \multicolumn{10}{|l|}{\begin{tabular}{|l|} 
Net Operating Revenues Ratio \\
\end{tabular}} \\
\hline$\Delta$ Unrestricted Net Assets & $\$ 1,977,382$ & $\$ 1,394,493$ & $\$ 1,564,832$ & $-\$ 2,129,583$ & $-\$ 7,756,533$ & $\$ 704,400$ & $\$ 66,168$ & $-\$ 759,367$ & $\$ 3,456,079$ \\
\hline Total Unrestricted Revenue & $\$ 11,267,292$ & $\$ 12,665,759$ & $\$ 14,895,504$ & $\$ 16,524,513$ & $\$ 16,413,988$ & $\$ 17,433,130$ & $\$ 17,768,733$ & $\$ 18,567,642$ & $\$ 19,127,904$ \\
\hline Ratio & 0.18 & 0.11 & 0.11 & \begin{tabular}{|c|}
-0.13 \\
\end{tabular} & \begin{tabular}{|c|}
-0.47 \\
\end{tabular} & 0.04 & 0.00 & \begin{tabular}{l|l|}
-0.04 \\
\end{tabular} & 0.18 \\
\hline Strength Factor & 3.00 & 3.00 & 3.00 & -1.00 & -1.00 & 3.00 & 1.19 & -0.02 & 3.00 \\
\hline Weighted Value (25\%) & 0.75 & 0.75 & 0.75 & -0.25 & -0.25 & 0.75 & \begin{tabular}{l|l}
0.30 \\
\end{tabular} & \begin{tabular}{ll|}
-0.01 \\
\end{tabular} & 0.75 \\
\hline \multicolumn{10}{|l|}{ Risk Factors } \\
\hline $\begin{array}{l}\text { Enrollment } \\
<1,000(2) \text { or }<2,500(1)\end{array}$ & 563 & 582 & 669 & 659 & 641 & 651 & 626 & 618 & 618 \\
\hline $\begin{array}{l}\text { Religious or Non-Degree Granting } \\
\text { yes }\end{array}$ & yes & yes & yes & yes & yes & yes & yes & yes & yes \\
\hline $\begin{array}{l}\text { Ratio of Full-time to Part-time Students } \\
<3.0\end{array}$ & 38.3 & 147.0 & 231.0 & 169.0 & no $\mathrm{P} / \mathrm{T}$ & 47.0 & 199.0 & no $P / T$ & no $\mathrm{P} / \mathrm{T}$ \\
\hline $\begin{array}{l}\text { Tuition Discounting } \\
>60 \%\end{array}$ & $35 \%$ & $36 \%$ & $38 \%$ & $45 \%$ & $47 \%$ & $47 \%$ & $59 \%$ & $61 \%$ & $61 \%$ \\
\hline $\begin{array}{l}\text { Tuition Reliance } \\
>85 \%\end{array}$ & $41 \%$ & $49 \%$ & $61 \%$ & $58 \%$ & $75 \%$ & $60 \%$ & $62 \%$ & $66 \%$ & $66 \%$ \\
\hline $\begin{array}{l}\text { Interest Expense } \\
>10 \%\end{array}$ & $3 \%$ & $4 \%$ & $32 \%$ & $3 \%$ & $3 \%$ & $3 \%$ & $3 \%$ & $2 \%$ & $3 \%$ \\
\hline $\begin{array}{l}\text { Net Revenue } \\
<0\end{array}$ & $\$ 1,423,571$ & $\$ 1,534,003$ & $\$ 20,804,805$ & $-\$ 1,385,598$ & $-\$ 4,163,299$ & $\$ 782,644$ & $\$ 301,425$ & $\$ 280,464$ & $\$ 3,874,576$ \\
\hline $\begin{array}{l}\text { Endowment/Total Budget } \\
<3.0\end{array}$ & 0.84 & 0.83 & 0.09 & 0.94 & 1.34 & 1.17 & 0.98 & 1.03 & 0.00 \\
\hline Total Risk Factors & 4 & 4 & 5 & 5 & 5 & 4 & 4 & 5 & 4 \\
\hline Strength Factor & -1 & -1 & -1 & -1 & -1 & -1 & -1 & -1 & -1 \\
\hline Weighted Value (25\%) & -0.25 & -0.25 & -0.25 & -0.25 & -0.25 & -0.25 & -0.25 & -0.25 & -0.25 \\
\hline
\end{tabular}




\section{Caldwell College}

\begin{tabular}{|c|c|c|c|c|c|c|c|c|c|}
\hline Year & 2005 & 2006 & 2007 & 2008 & 2009 & 2010 & 2011 & 2012 & 2013 \\
\hline MRA Composite Index & & & 1.4 & 1.0 & 0.4 & 0.7 & $1.2 \mid$ & 1.5 & 1.7 \\
\hline FRCS & & & 2.7 & 0.7 & 0.5 & 1.2 & 1.6 & 1.8 & 2.3 \\
\hline \multicolumn{10}{|l|}{ Index Components } \\
\hline Primary Reserve Ratio (25\%) & 0.10 & 0.12 & 0.19 & 0.08 & -0.01 & 0.08 & 0.13 & 0.16 & 0.25 \\
\hline Equity Ratio (12.5\%) & 0.31 & 0.32 & 0.28 & 0.26 & 0.24 & 0.25 & 0.30 & 0.33 & 0.35 \\
\hline Return on Net Assets Ratio (12.5\%) & -0.13 & 0.38 & 0.38 & -0.13 & -0.13 & 0.38 & 0.38 & 0.38 & 0.38 \\
\hline Net Operating Revenues Ratio (25\%) & -0.01 & 0.40 & 0.75 & 0.08 & 0.16 & 0.59 & 0.75 & 0.75 & 0.75 \\
\hline Risk Factors (25\%) & -0.25 & 0.25 & 0.25 & 0.00 & -0.25 & 0.00 & 0.00 & 0.00 & 0.00 \\
\hline MRA Index (Single Year) & 0.0 & \begin{tabular}{c|c}
1.5 \\
\end{tabular} & \begin{tabular}{l|l}
1.8 & 0 \\
\end{tabular} & \begin{tabular}{l|l}
0.3 \\
\end{tabular} & \begin{tabular}{l|l}
0.0 \\
\end{tabular} & \begin{tabular}{l|l}
1.3 & \\
\end{tabular} & \begin{tabular}{l|l}
1.6 & 0 \\
\end{tabular} & $\begin{array}{ll}1.6 \\
\end{array}$ & 1.7 \\
\hline \multicolumn{10}{|l|}{ Primary Reserve Ratio } \\
\hline Unrestricted Net Assets & $\$ 7,874,513$ & $\$ 8,239,927$ & $\$ 10,385,705$ & $\$ 9,335,595$ & $\$ 8,776,147$ & $\$ 9,903,955$ & $\$ 13,368,777$ & $\$ 15,510,815$ & $\$ 18,423,118$ \\
\hline Temporarily-restricted Net Assets & $\$ 1,997,762$ & $\$ 2,537,645$ & $\$ 2,822,329$ & $\$ 2,832,046$ & $\$ 1,252,329$ & $\$ 1,103,937$ & $\$ 928,005$ & $\$ 834,403$ & $\$ 917,401$ \\
\hline $\begin{array}{l}\text { Land, Building and Equipment, } \\
\text { net of depreciation }\end{array}$ & $\$ 23,826,396$ & $\$ 24,190,208$ & $\$ 33,902,227$ & $\$ 36,488,930$ & $\$ 35,123,645$ & $\$ 33,627,921$ & $\$ 34,740,473$ & $\$ 35,084,883$ & $\$ 35,526,973$ \\
\hline Long-term Debt & $\$ 15,283,905$ & $\$ 14,985,774$ & $\$ 23,409,385$ & $\$ 25,584,358$ & $\$ 24,916,387$ & $\$ 23,899,277$ & $\$ 22,799,793$ & $\$ 21,987,420$ & $\$ 21,339,872$ \\
\hline Total Expenses & $\$ 32,386,065$ & $\begin{array}{l}33,543,970 \\
\end{array}$ & $\$ 36,331,282$ & $\$ 40,644,816$ & $\$ 43,616,525$ & $\$ 42,548,350$ & $\begin{array}{l}44,684,682 \\
\end{array}$ & $\$ 50,162,904$ & $\$ 51,777,404$ \\
\hline Ratio & 0.04 & 0.05 & 0.07 & 0.03 & 0.00 & \begin{tabular}{l|l}
0.03 \\
\end{tabular} & 0.05 & 0.06 & 0.10 \\
\hline Strength Factor & 0.41 & 0.47 & 0.75 & 0.31 & -0.04 & 0.30 & 0.53 & 0.65 & 1.00 \\
\hline Weighted Value $(25 \%)$ & 0.10 & \begin{tabular}{l|l}
0.12 & 0 \\
\end{tabular} & \begin{tabular}{l|l}
0.19 \\
\end{tabular} & 0.08 & \begin{tabular}{ll|}
-0.01 \\
\end{tabular} & $\begin{array}{ll}0.08 \\
\end{array}$ & \begin{tabular}{l|l}
0.13 & 0 \\
\end{tabular} & $\begin{array}{ll}0.16 \\
\end{array}$ & 0.25 \\
\hline \multicolumn{10}{|l|}{ Equity Ratio } \\
\hline Net Assets & $\$ 13,378,423$ & $\$ 14,352,123$ & $\$ 16,977,174$ & $\$ 15,808,233$ & $\$ 13,378,369$ & $\$ 14,466,078$ & $\$ 17,977,499$ & $\$ 20,068,657$ & $\$ 23,270,312$ \\
\hline Intangible Assets & $\$ 0$ & $\$ 0$ & $\$ 0$ & $\$ 0$ & $\$ 0$ & $\$ 0$ & $\$ 0$ & $\$ 0$ & $\$ 0$ \\
\hline Unsecured Related-party Receivables & $\$ 0$ & $\$ 0$ & $\$ 0$ & $\$ 0$ & $\$ 0$ & $\$ 0$ & $\$ 0$ & $\$ 0$ & $\$ 0$ \\
\hline Total Assets & $\$ 32,024,689$ & $\$ 33,204,756$ & $\$ 45,525,930$ & $\$ 45,568,658$ & $\$ 42,217,451$ & $\$ 42,931,549$ & $\$ 45,429,991$ & $\$ 45,289,435$ & $\$ 49,803,805$ \\
\hline - Intangible Assets & $\$ 0$ & $\$ 0$ & $\$ 0$ & $\$ 0$ & $\$ 0$ & $\$ 0$ & $\$ 0$ & $\$ 0$ & $\$ 0$ \\
\hline - Unsecured Related-party Receivables & $\$ 0$ & $\$ 0$ & $\$ 0$ & $\$ 0$ & $\$ 0$ & $\$ 0$ & $\$ 0$ & $\$ 0$ & $\$ 0$ \\
\hline Ratio & 0.42 & 0.43 & 0.37 & 0.35 & 0.32 & 0.34 & 0.40 & 0.44 & 0.47 \\
\hline Strength Factor & 2.51 & 2.59 & 2.24 & 2.08 & 1.90 & 2.02 & 2.37 & 2.66 & 2.80 \\
\hline Weighted Value (12.5\%) & 0.31 & $\begin{array}{ll}0.32 \\
\end{array}$ & \begin{tabular}{l|l|l}
0.28 & 0 \\
\end{tabular} & 0.26 & 0.24 & $\begin{array}{ll}0.25 \\
\end{array}$ & \begin{tabular}{l|l}
0.30 & 0 \\
\end{tabular} & \begin{tabular}{l|l}
0.33 \\
\end{tabular} & 0.35 \\
\hline \multicolumn{10}{|l|}{ Return on Net Assets Ratio } \\
\hline$\Delta$ Net Assets & $-\$ 685,002$ & $\$ 973,700$ & $\$ 2,625,051$ & $-\$ 1,168,941$ & $-\$ 2,429,864$ & $\$ 1,087,709$ & $\$ 3,511,421$ & $\$ 2,091,158$ & $\$ 3,201,655$ \\
\hline Total Net Assets (BOY) & $\$ 14,063,425$ & $\$ 13,378,423$ & $\$ 14,352,123$ & $\$ 16,977,174$ & $\$ 15,808,233$ & $\$ 13,378,369$ & \begin{tabular}{l|l|l}
$\$ 14,466,078$ & \\
\end{tabular} & $\$ 17,977,499$ & $\$ 20,068,657$ \\
\hline Ratio & -0.05 & 0.07 & \begin{tabular}{l|l}
0.18 \\
\end{tabular} & \begin{tabular}{|c|}
-0.07 \\
\end{tabular} & -0.15 & \begin{tabular}{l|l}
0.08 \\
\end{tabular} & 0.24 & \begin{tabular}{l|l}
0.12 \\
\end{tabular} & 0.16 \\
\hline Strength Factor & -1.00 & 3.00 & 3.00 & -1.00 & -1.00 & 3.00 & 3.00 & 3.00 & 3.00 \\
\hline Weighted Value (12.5\%) & -0.13 & \begin{tabular}{l|l|l}
0.38 & 0 \\
\end{tabular} & \begin{tabular}{l|l|l}
0.38 & 0 \\
\end{tabular} & -0.13 & \begin{tabular}{ll|}
-0.13 \\
\end{tabular} & \begin{tabular}{ll|l}
0.38 & 0 \\
\end{tabular} & \begin{tabular}{l|l}
0.38 & 0 \\
\end{tabular} & \begin{tabular}{l|l}
0.38 \\
\end{tabular} & 0.38 \\
\hline \multicolumn{10}{|l|}{ Net Operating Revenues Ratio } \\
\hline$\Delta$ Unrestricted Net Assets & $-\$ 1,169,338$ & $\$ 365,414$ & $\$ 2,145,778$ & $-\$ 1,050,110$ & $-\$ 559,448$ & $\$ 1,127,808$ & $\$ 3,464,822$ & $\$ 2,142,038$ & $\$ 2,912,303$ \\
\hline Total Unrestricted Revenue & $\$ 28,189,917$ & $\begin{array}{l}30,500,870 \\
\end{array}$ & $\$ 33,336,125$ & $\$ 38,190,908$ & $\$ 40,004,291$ & $\$ 40,957,560$ & $\begin{array}{l}45,071,950 \\
\end{array}$ & $\$ 48,092,033$ & $\$ 51,956,758$ \\
\hline Ratio & -0.04 & 0.01 & \begin{tabular}{l|l}
0.06 \\
\end{tabular} & -0.03 & -0.01 & 0.03 & \begin{tabular}{l|l|}
0.08 \\
\end{tabular} & 0.04 & 0.06 \\
\hline Strength Factor & -0.04 & \begin{tabular}{|c|c|}
1.60 \\
\end{tabular} & 3.00 & 0.31 & 0.65 & 2.38 & 3.00 & 3.00 & 3.00 \\
\hline Weighted Value (25\%) & \begin{tabular}{l|l|l|}
-0.01 \\
\end{tabular} & \begin{tabular}{l|l}
0.40 \\
\end{tabular} & \begin{tabular}{ll|l}
0.75 \\
\end{tabular} & 0.08 & 0.16 & $\begin{array}{ll}0.59 \\
\end{array}$ & \begin{tabular}{l|l}
0.75 \\
\end{tabular} & 0.75 & 0.75 \\
\hline \multicolumn{10}{|l|}{ Risk Factors } \\
\hline $\begin{array}{l}\text { Enrollment } \\
<1,000(2) \text { or }<2,500(1)\end{array}$ & 1551 & 1596 & 1627 & 1643 & 1690 & 1675 & 1758 & 1726 & 1726 \\
\hline $\begin{array}{l}\text { Religious or Non-Degree Granting } \\
\text { yes }\end{array}$ & yes & yes & yes & yes & yes & yes & yes & yes & yes \\
\hline $\begin{array}{l}\text { Ratio of Full-time to Part-time Students } \\
<3.0\end{array}$ & 4.3 & 24.8 & no $\mathrm{P} / \mathrm{T}$ & no $\mathrm{P} / \mathrm{T}$ & no $\mathrm{P} / \mathrm{T}$ & no $\mathrm{P} / \mathrm{T}$ & no $P / T$ & no $\mathrm{P} / \mathrm{T}$ & no $\mathrm{P} / \mathrm{T}$ \\
\hline $\begin{array}{l}\text { Tuition Discounting } \\
>60 \%\end{array}$ & $27 \%$ & $26 \%$ & $27 \%$ & $29 \%$ & $29 \%$ & $29 \%$ & $31 \%$ & $33 \%$ & $33 \%$ \\
\hline $\begin{array}{l}\text { Tuition Reliance } \\
>85 \%\end{array}$ & $85 \%$ & $85 \%$ & $83 \%$ & $90 \%$ & $96 \%$ & $93 \%$ & $94 \%$ & $87 \%$ & $87 \%$ \\
\hline $\begin{array}{l}\text { Interest Expense } \\
>10 \%\end{array}$ & $2 \%$ & $2 \%$ & $3 \%$ & $3 \%$ & $5 \%$ & $4 \%$ & $3 \%$ & $3 \%$ & $3 \%$ \\
\hline $\begin{array}{l}\text { Net Revenue } \\
<0\end{array}$ & $-\$ 991,270$ & $\$ 751,654$ & $\$ 1,992,896$ & $\$ 355,157$ & $-\$ 1,655,648$ & $\$ 1,154,264$ & $\$ 2,513,948$ & $\$ 2,418,468$ & $\$ 2,395,311$ \\
\hline $\begin{array}{l}\text { Endowment/Total Budget } \\
<3.0\end{array}$ & 6.48 & 6.67 & 6.05 & 7.32 & 9.35 & 8.35 & 7.51 & 8.59 & 0.00 \\
\hline Total Risk Factors & 4 & 2 & 2 & 3 & 4 & 3 & 3 & \begin{tabular}{l|l}
3 \\
\end{tabular} & 3 \\
\hline Strength Factor & \begin{tabular}{l|l}
-1 \\
\end{tabular} & 1 & 1 & 0 & -1 & 0 & 0 & 0 & 0 \\
\hline Weighted Value $(25 \%)$ & \begin{tabular}{|c|}
-0.25 \\
\end{tabular} & \begin{tabular}{l|l|}
0.25 \\
\end{tabular} & \begin{tabular}{ll|}
0.25 \\
\end{tabular} & 0.00 & $\begin{array}{l}-0.25 \\
\end{array}$ & \begin{tabular}{l|l|}
0.00 \\
\end{tabular} & \begin{tabular}{l|l|}
0.00 \\
\end{tabular} & \begin{tabular}{l|l|}
0.00 \\
\end{tabular} & 0.00 \\
\hline
\end{tabular}




\section{Catawba College}

\begin{tabular}{|c|c|c|c|c|c|c|c|c|c|}
\hline Year & 2005 & 2006 & 2007 & 2008 & 2009 & 2010 & 2011 & 2012 & 2013 \\
\hline MRA Composite Index & & & 1.3 & 1.3 & 0.6 & 1.2 & 1.6 & 1.8 & 2.2 \\
\hline FRCS & & & 2.2 & 2.5 & 0.6 & 1.4 & 1.6 & 1.4 & 2.2 \\
\hline \multicolumn{10}{|l|}{ Index Components } \\
\hline Primary Reserve Ratio (25\%) & 0.75 & 0.75 & 0.75 & 0.75 & 0.03 & 0.16 & 0.63 & 0.42 & 0.60 \\
\hline Equity Ratio (12.5\%) & 0.38 & 0.38 & 0.38 & 0.38 & 0.38 & 0.38 & 0.38 & 0.38 & 0.38 \\
\hline Return on Net Assets Ratio (12.5\%) & 0.38 & 0.29 & 0.05 & -0.13 & -0.13 & 0.38 & 0.38 & -0.10 & 0.38 \\
\hline Net Operating Revenues Ratio (25\%) & 0.17 & -0.25 & -0.25 & 0.19 & -0.25 & 0.75 & 0.24 & 0.75 & 0.75 \\
\hline Risk Factors $(25 \%)$ & 0.25 & 0.25 & 0.00 & 0.25 & 0.00 & 0.25 & 0.25 & 0.25 & 0.50 \\
\hline MRA Index (Single Year) & 1.9 & 1.4 & 0.9 & 1.4 & 0.0 & 1.9 & 1.9 & 1.7 & 2.6 \\
\hline \multicolumn{10}{|l|}{ Primary Reserve Ratio } \\
\hline Unrestricted Net Assets & $\$ 30,228,542$ & $\$ 27,055,534$ & $\$ 23,959,739$ & $\$ 23,688,383$ & $\$ 14,296,311$ & $\$ 16,942,538$ & $\$ 16,898,467$ & $\$ 19,724,857$ & $\$ 24,125,526$ \\
\hline Temporarily-restricted Net Assets & $\$ 7,976,512$ & $\$ 10,890,940$ & $\$ 13,689,296$ & $\$ 10,515,742$ & $\$ 8,198,027$ & $\$ 8,417,465$ & $\$ 16,801,819$ & $\$ 11,847,227$ & $\$ 14,560,783$ \\
\hline $\begin{array}{l}\text { Land, Building and Equipment, } \\
\text { net of depreciation }\end{array}$ & $\$ 47,028,280$ & $\$ 46,209,112$ & $\$ 51,626,444$ & $\$ 59,311,369$ & $\$ 59,583,914$ & $\$ 58,847,301$ & $\$ 55,934,814$ & $\$ 56,248,072$ & $\$ 56,713,126$ \\
\hline Long-term Debt & $\$ 20,289,454$ & $\$ 23,273,940$ & $\$ 39,502,357$ & $\$ 39,477,516$ & $\$ 37,533,217$ & $\$ 36,032,868$ & $\$ 32,613,490$ & $\$ 31,663,000$ & $\$ 28,130,748$ \\
\hline Total Expenses & $\$ 32,724,127$ & $\$ 34,327,870$ & $\$ 36,771,568$ & $\$ 38,530,498$ & $\$ 38,979,175$ & $\$ 40,353,280$ & $\$ 41,417,149$ & $\$ 41,955,539$ & $\$ 42,104,990$ \\
\hline Ratio & 0.35 & 0.44 & 0.69 & 0.37 & 0.01 & 0.06 & 0.25 & 0.17 & 0.24 \\
\hline Strength Factor & 3.00 & 3.00 & 3.00 & 3.00 & 0.11 & 0.63 & 2.51 & 1.67 & 2.40 \\
\hline Weighted Value (25\%) & 0.75 & 0.75 & 0.75 & 0.75 & 0.03 & 0.16 & 0.63 & 0.42 & 0.60 \\
\hline
\end{tabular}

\begin{tabular}{|c|c|c|c|c|c|c|c|c|c|}
\hline \multicolumn{10}{|l|}{ Equity Ratio } \\
\hline Net Assets & $\$ 69,106,226$ & $\$ 72,326,234$ & $\$ 72,885,166$ & $\$ 70,246,711$ & $\$ 57,710,125$ & $\$ 63,257,930$ & $\$ 76,795,658$ & $\$ 75,519,643$ & $\$ 83,436,718$ \\
\hline Intangible Assets & $\$ 0$ & $\$ 0$ & $\$ 0$ & $\$ 0$ & $\$ 0$ & $\$ 0$ & $\$ 0$ & $\$ 0$ & $\$ 0$ \\
\hline Unsecured Related-party Receivables & $\$ 0$ & $\$ 0$ & $\$ 0$ & $\$ 0$ & $\$ 0$ & $\$ 0$ & $\$ 0$ & $\$ 0$ & $\$ 0$ \\
\hline Total Assets & $\$ 92,819,126$ & $\$ 98,408,394$ & $\$ 116,048,740$ & $\$ 113,696,520$ & $\$ 98,811,762$ & $\$ 102,702,687$ & $\$ 111,644,818$ & $\$ 109,380,675$ & $\$ 114,993,967$ \\
\hline - Intangible Assets & $\$ 0$ & $\$ 0$ & $\$ 0$ & $\$ 0$ & $\$ 0$ & $\$ 0$ & $\$ 0$ & $\$ 0$ & $\$ 0$ \\
\hline - Unsecured Related-party Receivables & $\$ 0$ & $\$ 0$ & $\$ 0$ & $\$ 0$ & $\$ 0$ & $\$ 0$ & $\$ 0$ & $\$ 0$ & $\$ 0$ \\
\hline Ratio & 0.74 & 0.73 & 0.63 & 0.62 & 0.58 & 0.62 & 0.69 & 0.69 & 0.73 \\
\hline Strength Factor & 3.00 & 3.00 & 3.00 & 3.00 & 3.00 & 3.00 & 3.00 & 3.00 & 3.00 \\
\hline Weighted Value (12.5\%) & 0.38 & 0.38 & 0.38 & 0.38 & 0.38 & 0.38 & 0.38 & 0.38 & 0.38 \\
\hline \multicolumn{10}{|l|}{ Return on Net Assets Ratio } \\
\hline$\Delta$ Net Assets & $\$ 5,345,397$ & $\$ 3,220,008$ & $\$ 558,932$ & $-\$ 2,638,455$ & $-\$ 12,536,586$ & $\$ 5,547,805$ & $\$ 13,537,728$ & $-\$ 1,276,015$ & $\$ 7,917,075$ \\
\hline Total Net Assets (BOY) & $\$ 63,760,829$ & $\$ 69,106,226$ & $\$ 72,326,234$ & $\$ 72,885,166$ & $\$ 70,246,711$ & $\$ 57,710,125$ & $\$ 63,257,930$ & $\$ 76,795,658$ & $\$ 75,519,643$ \\
\hline Ratio & 0.08 & 0.05 & 0.01 & -0.04 & -0.18 & 0.10 & 0.21 & -0.02 & 0.10 \\
\hline Strength Factor & 3.00 & 2.33 & 0.39 & -1.00 & -1.00 & 3.00 & 3.00 & -0.83 & 3.00 \\
\hline Weighted Value (12.5\%) & 0.38 & 0.29 & 0.05 & -0.13 & -0.13 & 0.38 & 0.38 & -0.10 & 0.38 \\
\hline \multicolumn{10}{|l|}{\begin{tabular}{|l|} 
Net Operating Revenues Ratio \\
\end{tabular}} \\
\hline$\Delta$ Unrestricted Net Assets & $-\$ 325,074$ & $-\$ 3,173,008$ & $-\$ 3,095,795$ & $-\$ 271,356$ & $-\$ 9,392,072$ & $\$ 2,646,227$ & $-\$ 44,071$ & $\$ 2,826,390$ & $\$ 4,400,669$ \\
\hline Total Unrestricted Revenue & $\$ 24,775,188$ & $\$ 24,478,360$ & $\$ 25,614,941$ & $\$ 27,062,392$ & $\$ 27,833,957$ & $\$ 33,076,409$ & $\$ 33,618,100$ & $\$ 35,396,893$ & $\$ 34,361,985$ \\
\hline Ratio & -0.01 & -0.13 & \begin{tabular}{l|l|}
-0.12 \\
\end{tabular} & -0.01 & -0.34 & 0.08 & 0.00 & 0.08 & 0.13 \\
\hline Strength Factor & 0.67 & -1.00 & -1.00 & 0.75 & -1.00 & 3.00 & 0.97 & 3.00 & 3.00 \\
\hline Weighted Value (25\%) & 0.17 & -0.25 & -0.25 & 0.19 & -0.25 & 0.75 & 0.24 & 0.75 & 0.75 \\
\hline \multicolumn{10}{|l|}{ Risk Factors } \\
\hline $\begin{array}{l}\text { Enrollment } \\
<1,000(2) \text { or }<2,500(1)\end{array}$ & 1350 & 1248 & 1223 & 1262 & 1203 & 1302 & 1269 & 1269 & 1269 \\
\hline $\begin{array}{l}\text { Religious or Non-Degree Granting } \\
\text { yes }\end{array}$ & no & no & no & no & no & no & no & no & no \\
\hline $\begin{array}{l}\text { Ratio of Full-time to Part-time Students } \\
<3.0\end{array}$ & no $\mathrm{P} / \mathrm{T}$ & no $\mathrm{P} / \mathrm{T}$ & no $\mathrm{P} / \mathrm{T}$ & no $P / T$ & 247.0 & 51.5 & no $\mathrm{P} / \mathrm{T}$ & no $\mathrm{P} / \mathrm{T}$ & no $\mathrm{P} / \mathrm{T}$ \\
\hline $\begin{array}{l}\text { Tuition Discounting } \\
>60 \%\end{array}$ & $37 \%$ & $44 \%$ & $45 \%$ & $46 \%$ & $47 \%$ & $47 \%$ & $48 \%$ & $50 \%$ & $50 \%$ \\
\hline $\begin{array}{l}\text { Tuition Reliance } \\
>85 \%\end{array}$ & $45 \%$ & $43 \%$ & $54 \%$ & $43 \%$ & $46 \%$ & $48 \%$ & $38 \%$ & $54 \%$ & $54 \%$ \\
\hline $\begin{array}{l}\text { Interest Expense } \\
>10 \%\end{array}$ & $2 \%$ & $2 \%$ & $2 \%$ & $3 \%$ & $3 \%$ & $4 \%$ & $3 \%$ & $3 \%$ & $3 \%$ \\
\hline $\begin{array}{l}\text { Net Revenue } \\
<0\end{array}$ & $\$ 4,329,001$ & $\$ 3,757,787$ & $-\$ 1,252,871$ & $\$ 198,408$ & $-\$ 2,281,391$ & $\$ 1,570,222$ & $\$ 8,661,298$ & $\$ 129,668$ & $\$ 2,411,136$ \\
\hline $\begin{array}{l}\text { Endowment/Total Budget } \\
<3.0\end{array}$ & 1.03 & 1.00 & 0.99 & 1.11 & 1.45 & 1.26 & 1.11 & 1.06 & 0.00 \\
\hline Total Risk Factors & 2 & 2 & 3 & 2 & 3 & 2 & 2 & 2 & 1 \\
\hline Strength Factor & 1 & 1 & 0 & 1 & 0 & 1 & 1 & 1 & 2 \\
\hline Weighted Value (25\%) & 0.25 & 0.25 & 0.00 & 0.25 & 0.00 & 0.25 & 0.25 & 0.25 & 0.50 \\
\hline
\end{tabular}




\section{Eureka College}

\begin{tabular}{|c|c|c|c|c|c|c|c|c|c|}
\hline Year & 2005 & 2006 & 2007 & 2008 & 2009 & 2010 & 2011 & 2012 & 2013 \\
\hline MRA Composite Index & & & 0.8 & 1.2 & 0.6 & 0.8 & 1.0 & 1.3 & 1.9 \\
\hline FRCS & & & \begin{tabular}{l|l|}
1.4 & \\
\end{tabular} & \begin{tabular}{ll|}
1.4 & \\
\end{tabular} & \begin{tabular}{l|l|l}
0.8 & \\
\end{tabular} & \begin{tabular}{ll|}
1.4 \\
\end{tabular} & 1.8 & 1.7 & 2.5 \\
\hline \multicolumn{10}{|l|}{ Index Components } \\
\hline Primary Reserve Ratio (25\%) & -0.25 & -0.25 & 0.11 & -0.25 & -0.25 & -0.25 & -0.25 & -0.25 & 0.72 \\
\hline Equity Ratio (12.5\%) & 0.29 & 0.28 & 0.37 & 0.38 & 0.37 & 0.38 & 0.38 & 0.38 & 0.38 \\
\hline Return on Net Assets Ratio (12.5\%) & 0.01 & 0.22 & 0.38 & 0.38 & -0.13 & 0.38 & 0.38 & 0.38 & 0.38 \\
\hline Net Operating Revenues Ratio (25\%) & -0.25 & 0.05 & 0.75 & 0.75 & -0.11 & 0.75 & 0.75 & 0.75 & 0.75 \\
\hline Risk Factors (25\%) & -0.25 & 0.00 & 0.00 & 0.00 & 0.00 & 0.00 & 0.00 & 0.00 & 0.25 \\
\hline MRA Index (Single Year) & -0.5 & 0.3 & 1.6 & \begin{tabular}{l|l}
1.3 \\
\end{tabular} & \begin{tabular}{l|l}
-0.1 \\
\end{tabular} & 1.3 & 1.3 & 1.3 & 2.5 \\
\hline \multicolumn{10}{|l|}{ Primary Reserve Ratio } \\
\hline Unrestricted Net Assets & $-\$ 6,613,697$ & $-\$ 6,819,864$ & $-\$ 4,648,126$ & $-\$ 3,691,342$ & $-\$ 4,320,499$ & $-\$ 2,733,941$ & $\$ 543,242$ & $\$ 2,158,946$ & $\$ 5,387,819$ \\
\hline Temporarily-restricted Net Assets & $\$ 2,390,368$ & $\$ 2,960,369$ & $\$ 3,166,152$ & $\$ 2,483,532$ & $\$ 1,829,591$ & $\$ 2,636,246$ & $\$ 3,380,445$ & $\$ 2,696,860$ & $\$ 4,980,695$ \\
\hline $\begin{array}{l}\text { Land, Building and Equipment, } \\
\text { net of depreciation }\end{array}$ & $\$ 9,256,093$ & $\$ 10,632,173$ & $\$ 11,168,402$ & $\$ 12,994,943$ & $\$ 14,598,152$ & $\$ 13,990,236$ & $\$ 16,449,642$ & $\$ 23,110,039$ & $\$ 22,922,779$ \\
\hline Long-term Debt & $\$ 11,934,476$ & $\$ 12,709,589$ & $\$ 13,124,689$ & $\$ 12,969,688$ & $\$ 13,401,048$ & $\$ 11,728,797$ & $\$ 10,584,113$ & $\$ 16,629,247$ & $\$ 16,979,181$ \\
\hline Total Expenses & $\$ 9,722,952$ & $\$ 10,883,510$ & $\$ 10,474,286$ & $\$ 11,334,668$ & $\$ 12,671,737$ & $\$ 13,051,724$ & $\$ 13,403,924$ & $\$ 14,198,231$ & $\$ 15,288,779$ \\
\hline Ratio & \begin{tabular}{ll|}
-0.16 \\
\end{tabular} & \begin{tabular}{ll|}
-0.16 \\
\end{tabular} & 0.05 & -0.11 & \begin{tabular}{l|l|}
-0.29 \\
\end{tabular} & \begin{tabular}{l|l|}
-0.18 \\
\end{tabular} & \begin{tabular}{l|l|}
-0.14 \\
\end{tabular} & \begin{tabular}{l|l|}
-0.11 \\
\end{tabular} & 0.29 \\
\hline Strength Factor & -1.00 & -1.00 & 0.45 & \begin{tabular}{ll|}
-1.00 \\
\end{tabular} & \begin{tabular}{ll|}
-1.00 \\
\end{tabular} & $\begin{array}{l}-1.00 \\
\end{array}$ & -1.00 & \begin{tabular}{ll|}
-1.00 \\
\end{tabular} & 2.89 \\
\hline Weighted Value $(25 \%)$ & -0.25 & -0.25 & 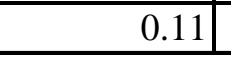 & $\begin{array}{l}-0.25 \\
\end{array}$ & $\begin{array}{l}-0.25 \\
\end{array}$ & $\begin{array}{l}-0.25 \\
\end{array}$ & -0.25 & -0.25 & 0.72 \\
\hline
\end{tabular}

\begin{tabular}{|c|c|c|c|c|c|c|c|c|c|}
\hline \multicolumn{10}{|l|}{ Equity Ratio } \\
\hline Net Assets & $\$ 7,814,057$ & $\$ 8,089,458$ & $\$ 13,110,477$ & $\$ 14,982,567$ & $\$ 13,678,253$ & $\$ 16,233,675$ & $\$ 21,016,576$ & $\$ 22,622,014$ & $\$ 29,953,882$ \\
\hline Intangible Assets & $\$ 0$ & $\$ 0$ & $\$ 0$ & $\$ 0$ & $\$ 0$ & $\$ 0$ & $\$ 0$ & $\$ 0$ & $\$ 0$ \\
\hline Unsecured Related-party Receivables & $\$ 0$ & $\$ 0$ & $\$ 0$ & $\$ 0$ & $\$ 0$ & $\$ 0$ & $\$ 0$ & $\$ 0$ & $\$ 0$ \\
\hline Total Assets & $\$ 20,079,052$ & $\$ 21,564,611$ & $\$ 26,557,460$ & $\$ 28,973,889$ & $\$ 27,660,497$ & $\$ 28,683,047$ & $\$ 33,970,137$ & $\$ 41,072,316$ & $\$ 47,467,592$ \\
\hline - Intangible Assets & $\$ 0$ & $\$ 0$ & $\$ 0$ & $\$ 0$ & $\$ 0$ & $\$ 0$ & $\$ 0$ & $\$ 0$ & $\$ 0$ \\
\hline - Unsecured Related-party Receivables & $\$ 0 \mid$ & $\$ 0$ & $\$ 0$ & $\$ 0$ & $\$ 0$ & $\$ 0$ & $\$ 0$ & $\$ 0 \mid$ & $\$ 0$ \\
\hline Ratio & \begin{tabular}{l|l}
0.39 \\
\end{tabular} & \begin{tabular}{l|l}
0.38 \\
\end{tabular} & 0.49 & 0.52 & 0.49 & 0.57 & \begin{tabular}{l|l}
0.62 & \\
\end{tabular} & 0.55 & 0.63 \\
\hline Strength Factor & 2.33 & 2.25 & 2.96 & 3.00 & 2.97 & 3.00 & 3.00 & 3.00 & 3.00 \\
\hline Weighted Value (12.5\%) & \begin{tabular}{l|l}
0.29 \\
\end{tabular} & \begin{tabular}{l|l}
0.28 \\
\end{tabular} & 0.37 & 0.38 & 0.37 & 0.38 & \begin{tabular}{l|l}
0.38 \\
\end{tabular} & \begin{tabular}{l|l}
0.38 \\
\end{tabular} & 0.38 \\
\hline \multicolumn{10}{|l|}{ Return on Net Assets Ratio } \\
\hline$\Delta$ Net Assets & $\$ 6,322$ & $\$ 275,401$ & $\$ 5,021,019$ & $\$ 1,872,090$ & $-\$ 1,304,314$ & $\$ 2,555,422$ & $\$ 4,782,901$ & $\$ 1,605,438$ & $\$ 7,331,868$ \\
\hline Total Net Assets (BOY) & $\$ 7,807,735$ & $\begin{array}{l}7,814,057 \\
\end{array}$ & $\$ 8,089,458$ & $\$ 13,110,477$ & $\$ 14,982,567$ & $\$ 13,678,253$ & $\$ 16,233,675$ & $\$ 21,016,576$ & $\$ 22,622,014$ \\
\hline Ratio & 0.00 & 0.04 & 0.62 & 0.14 & -0.09 & 0.19 & 0.29 & 0.08 & 0.32 \\
\hline Strength Factor & 0.04 & 1.76 & 3.00 & 3.00 & -1.00 & 3.00 & 3.00 & 3.00 & 3.00 \\
\hline Weighted Value (12.5\%) & 0.01 & \begin{tabular}{l|l}
0.22 & \\
\end{tabular} & 0.38 & 0.38 & -0.13 & 0.38 & \begin{tabular}{l|l}
0.38 \\
\end{tabular} & \begin{tabular}{ll|l}
0.38 & 0 \\
\end{tabular} & 0.38 \\
\hline \multicolumn{10}{|l|}{ Net Operating Revenues Ratio } \\
\hline$\Delta$ Unrestricted Net Assets & $-\$ 739,269$ & $-\$ 206,167$ & $\$ 2,171,738$ & $\$ 956,784$ & $-\$ 629,157$ & $\$ 1,586,558$ & $\$ 3,277,183$ & $\$ 1,615,704$ & $\$ 3,228,873$ \\
\hline Total Unrestricted Revenue & $\$ 6,508,235$ & $\$ 6,542,737$ & $\$ 7,732,593$ & $\$ 9,776,903$ & $\$ 11,029,521$ & $\$ 11,671,563$ & $\$ 12,177,919$ & $\$ 12,606,884$ & $\$ 12,174,570$ \\
\hline Ratio & \begin{tabular}{l|l}
-0.11 & \\
\end{tabular} & \begin{tabular}{l|l}
-0.03 & -1 \\
\end{tabular} & 0.28 & 0.10 & -0.06 & 0.14 & 0.27 & \begin{tabular}{l|l}
0.13 \\
\end{tabular} & 0.27 \\
\hline Strength Factor & -1.00 & 0.21 & 3.00 & 3.00 & -0.43 & 3.00 & 3.00 & 3.00 & 3.00 \\
\hline Weighted Value (25\%) & \begin{tabular}{|c|c|c|c|}
-0.25 \\
\end{tabular} & \begin{tabular}{l|l|l|l|l|}
0.05 & \\
\end{tabular} & 0.75 & 0.75 & \begin{tabular}{|c|c|c|}
-0.11 \\
\end{tabular} & 0.75 & \begin{tabular}{l|l|l|l|}
0.75 \\
\end{tabular} & $\begin{array}{l}0.75 \\
\end{array}$ & 0.75 \\
\hline \multicolumn{10}{|l|}{ Risk Factors } \\
\hline $\begin{array}{l}\text { Enrollment } \\
<1,000(2) \text { or }<2,500(1)\end{array}$ & 505 & 517 & 565 & 654 & 727 & 725 & 738 & 733 & 733 \\
\hline $\begin{array}{l}\text { Religious or Non-Degree Granting } \\
\text { yes }\end{array}$ & no & no & no & no & no & no & no & no & no \\
\hline $\begin{array}{l}\text { Ratio of Full-time to Part-time Students } \\
<3.0\end{array}$ & no $P / T$ & no $P / T$ & no $P / T$ & no $P / T$ & no $P / T$ & no $P / T$ & no $P / T$ & no $P / T$ & no $P / T$ \\
\hline $\begin{array}{l}\text { Tuition Discounting } \\
>60 \%\end{array}$ & $41 \%$ & $39 \%$ & $33 \%$ & $27 \%$ & $24 \%$ & $22 \%$ & $23 \%$ & $25 \%$ & $25 \%$ \\
\hline $\begin{array}{l}\text { Tuition Reliance } \\
>85 \%\end{array}$ & $67 \%$ & $56 \%$ & $51 \%$ & $75 \%$ & $83 \%$ & $77 \%$ & $70 \%$ & $78 \%$ & $78 \%$ \\
\hline $\begin{array}{l}\text { Interest Expense } \\
>10 \%\end{array}$ & $7 \%$ & $7 \%$ & $7 \%$ & $6 \%$ & $6 \%$ & $5 \%$ & $4 \%$ & $4 \%$ & $5 \%$ \\
\hline $\begin{array}{l}\text { Net Revenue } \\
<0\end{array}$ & $-\$ 159,487$ & $\$ 14,003$ & $\$ 4,557,994$ & $\$ 1,826,638$ & $\$ 1,420,124$ & $\$ 4,655,962$ & $\$ 5,639,011$ & $\$ 2,539,727$ & $\$ 6,216,729$ \\
\hline $\begin{array}{l}\text { Endowment/Total Budget } \\
<3.0\end{array}$ & 1.28 & 1.39 & 1.32 & 0.93 & 1.19 & 1.16 & 0.99 & 1.03 & 0.00 \\
\hline Total Risk Factors & 4 & 3 & 3 & 3 & 3 & $3 \mid$ & 3 & 3 & 2 \\
\hline Strength Factor & \begin{tabular}{l|l}
-1 \\
\end{tabular} & 0 & 0 & 0 & 0 & 0 & 0 & 0 & 1 \\
\hline Weighted Value (25\%) & -0.25 & \begin{tabular}{|c|c|c|}
0.00 \\
\end{tabular} & 0.00 & 0.00 & 0.00 & 0.00 & 0.00 & \begin{tabular}{|c|c|}
0.00 \\
\end{tabular} & 0.25 \\
\hline
\end{tabular}




\section{Georgetown College}

\begin{tabular}{|c|c|c|c|c|c|c|c|c|c|}
\hline Year & 2005 & 2006 & 2007 & 2008 & 2009 & 2010 & 2011 & 2012 & 2013 \\
\hline MRA Composite Index & & & 1.8 & 1.1 & 0.7 & 0.9 & 1.3 & 0.9 & 1.0 \\
\hline FRCS & & & $3 \mid$ & 1.7 & 0.5 & 1.3 & 2.0 & \#N/A & 0.9 \\
\hline \multicolumn{10}{|l|}{\begin{tabular}{|l} 
Index Components \\
\end{tabular}} \\
\hline Primary Reserve Ratio (25\%) & 0.75 & 0.75 & 0.75 & 0.75 & 0.40 & 0.51 & 0.67 & 0.61 & 0.55 \\
\hline Equity Ratio (12.5\%) & 0.38 & 0.38 & 0.38 & 0.36 & 0.30 & 0.30 & 0.33 & 0.27 & 0.29 \\
\hline Return on Net Assets Ratio (12.5\%) & 0.38 & -0.09 & 0.38 & -0.13 & -0.13 & 0.24 & 0.38 & -0.13 & 0.38 \\
\hline Net Operating Revenues Ratio (25\%) & 0.75 & -0.25 & 0.75 & -0.25 & -0.25 & 0.59 & 0.40 & -0.25 & 0.20 \\
\hline Risk Factors (25\%) & 0.00 & 0.00 & 0.00 & -0.25 & 0.00 & -0.25 & -0.25 & -0.25 & 0.00 \\
\hline MRA Index (Single Year) & 2.3 & 0.8 & 2.3 & 0.5 & 0.3 & 1.4 & 1.5 & 0.3 & 1.4 \\
\hline \multicolumn{10}{|l|}{ Primary Reserve Ratio } \\
\hline Unrestricted Net Assets & $\$ 16,749,298$ & $\$ 12,138,088$ & $\$ 14,742,440$ & $\$ 7,273,448$ & $-\$ 3,262,844$ & $-\$ 2,021,074$ & $-\$ 1,467,152$ & $-\$ 7,282,581$ & $-\$ 7,659,669$ \\
\hline Temporarily-restricted Net Assets & $\$ 4,053,256$ & $\$ 5,817,793$ & $\$ 6,128,246$ & $\$ 5,720,523$ & $\$ 4,869,475$ & $\$ 4,119,795$ & $\$ 8,856,249$ & $\$ 8,553,199$ & $\$ 9,762,577$ \\
\hline $\begin{array}{l}\text { Land, Building and Equipment, } \\
\text { net of depreciation }\end{array}$ & $\$ 49,200,966$ & $\$ 47,986,849$ & $\$ 47,265,103$ & $\$ 45,999,157$ & $\$ 44,548,182$ & $\$ 44,050,343$ & $\$ 44,031,391$ & $\$ 44,825,979$ & $\$ 45,771,465$ \\
\hline Long-term Debt & $\$ 45,983,522$ & $\$ 47,460,582$ & $\$ 47,701,477$ & $\$ 49,246,829$ & $\$ 51,030,638$ & $\$ 52,568,037$ & $\$ 51,180,349$ & $\$ 57,460,860$ & $\$ 55,646,472$ \\
\hline Total Expenses & $\$ 39,656,322$ & $\$ 43,945,370$ & $\$ 46,702,681$ & $\$ 48,701,566$ & $\$ 50,436,390$ & $\$ 52,012,872$ & $\$ 54,518,194$ & $\$ 57,281,677$ & $\$ 54,179,094$ \\
\hline Ratio & 0.44 & 0.40 & 0.46 & 0.33 & 0.16 & 0.20 & 0.27 & 0.24 & 0.22 \\
\hline Strength Factor & 3.00 & 3.00 & 3.00 & 3.00 & 1.60 & 2.04 & 2.67 & 2.43 & 2.21 \\
\hline Weighted Value (25\%) & 0.75 & 0.75 & 0.75 & 0.75 & 0.40 & 0.51 & 0.67 & 0.61 & 0.55 \\
\hline
\end{tabular}

\begin{tabular}{|c|c|c|c|c|c|c|c|c|c|}
\hline \multicolumn{10}{|l|}{ Equity Ratio } \\
\hline Net Assets & $\$ 52,404,316$ & $\$ 51,633,891$ & $\$ 55,949,817$ & $\$ 47,449,796$ & $\$ 35,202,334$ & $\$ 36,550,231$ & $\$ 43,682,359$ & $\$ 35,764,487$ & $\$ 38,360,509$ \\
\hline Intangible Assets & $\$ 0$ & $\$ 0$ & $\$ 0$ & $\$ 0$ & $\$ 0$ & $\$ 0$ & $\$ 0$ & $\$ 0$ & $\$ 0$ \\
\hline Unsecured Related-party Receivables & $\$ 0$ & $\$ 0$ & $\$ 0$ & $\$ 0$ & $\$ 0$ & $\$ 0$ & $\$ 0$ & $\$ 0$ & $\$ 0$ \\
\hline Total Assets & $\$ 102,136,214$ & $\$ 102,971,901$ & $\$ 107,288,088$ & $\$ 100,187,877$ & $\$ 89,407,885$ & $\$ 92,685,189$ & $\$ 99,582,362$ & $\$ 97,779,618$ & $\$ 98,512,803$ \\
\hline - Intangible Assets & $\$ 0$ & $\$ 0$ & $\$ 0$ & $\$ 0$ & $\$ 0$ & $\$ 0$ & $\$ 0$ & $\$ 0$ & $\$ 0$ \\
\hline - Unsecured Related-party Receivables & $\$ 0$ & $\$ 0$ & $\$ 0$ & $\$ 0$ & $\$ 0$ & $\$ 0$ & $\$ 0$ & $\$ 0$ & $\$ 0$ \\
\hline Ratio & 0.51 & 0.50 & 0.52 & 0.47 & 0.39 & 0.39 & 0.44 & 0.37 & 0.39 \\
\hline Strength Factor & 3.00 & 3.00 & 3.00 & 2.84 & 2.36 & 2.37 & 2.63 & 2.19 & 2.34 \\
\hline Weighted Value (12.5\%) & 0.38 & 0.38 & 0.38 & 0.36 & 0.30 & 0.30 & 0.33 & 0.27 & 0.29 \\
\hline \multicolumn{10}{|l|}{ Return on Net Assets Ratio } \\
\hline$\Delta$ Net Assets & $\$ 3,957,828$ & $-\$ 770,425$ & $\$ 4,315,926$ & $-\$ 8,500,021$ & $-\$ 12,247,462$ & $\$ 1,347,897$ & $\$ 7,132,128$ & $-\$ 7,917,872$ & $\$ 2,596,022$ \\
\hline Total Net Assets (BOY) & $\$ 48,446,488$ & $\$ 52,404,316$ & $\$ 51,633,891$ & $\$ 55,949,817$ & $\$ 47,449,796$ & $\$ 35,202,334$ & $\$ 36,550,231$ & $\$ 43,682,359$ & $\$ 35,764,487$ \\
\hline Ratio & 0.08 & -0.01 & 0.08 & -0.15 & -0.26 & 0.04 & 0.20 & -0.18 & 0.07 \\
\hline Strength Factor & 3.00 & -0.74 & 3.00 & -1.00 & -1.00 & 1.91 & 3.00 & -1.00 & 3.00 \\
\hline Weighted Value (12.5\%) & 0.38 & $\begin{array}{ll}-0.09 \\
\end{array}$ & 0.38 & -0.13 & -0.13 & 0.24 & 0.38 & -0.13 & 0.38 \\
\hline \multicolumn{10}{|l|}{ Net Operating Revenues Ratio } \\
\hline$\Delta$ Unrestricted Net Assets & $\$ 1,460,130$ & $-\$ 4,611,210$ & $\$ 2,604,352$ & $-\$ 7,468,992$ & $-\$ 10,536,292$ & $\$ 1,241,770$ & $\$ 553,922$ & $-\$ 5,815,429$ & $-\$ 377,088$ \\
\hline Total Unrestricted Revenue & $\$ 31,061,948$ & $\$ 35,581,876$ & $\$ 38,427,431$ & $\$ 41,254,937$ & $\$ 42,742,072$ & $\$ 45,647,709$ & $\$ 46,687,547$ & $\$ 48,496,799$ & $\$ 43,873,179$ \\
\hline Ratio & 0.05 & -0.13 & 0.07 & -0.18 & -0.25 & 0.03 & 0.01 & -0.12 & -0.01 \\
\hline Strength Factor & 3.00 & -1.00 & 3.00 & -1.00 & -1.00 & 2.36 & 1.59 & -1.00 & 0.79 \\
\hline Weighted Value $(25 \%)$ & 0.75 & -0.25 & 0.75 & -0.25 & -0.25 & 0.59 & 0.40 & -0.25 & 0.20 \\
\hline \multicolumn{10}{|l|}{ Risk Factors } \\
\hline $\begin{array}{l}\text { Enrollment } \\
<1,000(2) \text { or }<2,500(1)\end{array}$ & 1517 & 1583 & 1591 & 1574 & 1528 & 1528 & 1489 & 1469 & 1469 \\
\hline $\begin{array}{l}\text { Religious or Non-Degree Granting } \\
\text { yes }\end{array}$ & yes & yes & yes & yes & yes & yes & yes & yes & yes \\
\hline $\begin{array}{l}\text { Ratio of Full-time to Part-time Students } \\
<3.0\end{array}$ & no $\mathrm{P} / \mathrm{T}$ & no $P / T$ & no $P / T$ & 183.0 & 378.0 & no $\mathrm{P} / \mathrm{T}$ & no $\mathrm{P} / \mathrm{T}$ & 351.0 & no $\mathrm{P} / \mathrm{T}$ \\
\hline $\begin{array}{l}\text { Tuition Discounting } \\
>60 \%\end{array}$ & $39 \%$ & $41 \%$ & $45 \%$ & $41 \%$ & $43 \%$ & $45 \%$ & $49 \%$ & $50 \%$ & $50 \%$ \\
\hline $\begin{array}{l}\text { Tuition Reliance } \\
>85 \%\end{array}$ & $66 \%$ & $65 \%$ & $76 \%$ & $85 \%$ & $77 \%$ & $82 \%$ & $75 \%$ & $80 \%$ & $80 \%$ \\
\hline $\begin{array}{l}\text { Interest Expense } \\
>10 \%\end{array}$ & $0 \%$ & $6 \%$ & $4 \%$ & $4 \%$ & $5 \%$ & $4 \%$ & $4 \%$ & $4 \%$ & $4 \%$ \\
\hline $\begin{array}{l}\text { Net Revenue } \\
<0\end{array}$ & $\$ 1,512,633$ & $\$ 6,388,241$ & $\$ 826,451$ & $-\$ 11,878$ & $\$ 265,339$ & $-\$ 576,527$ & $-\$ 759,270$ & $-\$ 1,680,250$ & $-\$ 1,416,163$ \\
\hline $\begin{array}{l}\text { Endowment/Total Budget } \\
<3.0\end{array}$ & 1.10 & 1.21 & 1.11 & 1.25 & 1.67 & 1.53 & 1.34 & 1.47 & 0.00 \\
\hline Total Risk Factors & 3 & 3 & 3 & 4 & 3 & 4 & 4 & 4 & 3 \\
\hline Strength Factor & 0 & 0 & 0 & -1 & 0 & -1 & -1 & -1 & 0 \\
\hline Weighted Value $(25 \%)$ & 0.00 & 0.00 & 0.00 & -0.25 & 0.00 & -0.25 & -0.25 & -0.25 & 0.00 \\
\hline
\end{tabular}


Greensboro College

\begin{tabular}{|c|c|c|c|c|c|c|c|c|c|}
\hline Year & 2005 & 2006 & 2007 & 2008 & 2009 & 2010 & 2011 & 2012 & 2013 \\
\hline MRA Composite Index & & & 2.3 & 1.5 & 0.5 & 0.1 & 0.3 & 0.7 & 1.5 \\
\hline FRCS & & & $3 \mid$ & 1.5 & 0.7 & 1.2 & 0.8 & 1.6 & 2.0 \\
\hline \multicolumn{10}{|l|}{ Index Components } \\
\hline Primary Reserve Ratio (25\%) & 0.58 & 0.69 & 0.75 & 0.51 & -0.20 & -0.08 & -0.10 & 0.01 & 0.16 \\
\hline Equity Ratio (12.5\%) & 0.38 & 0.38 & 0.38 & 0.38 & 0.35 & 0.35 & 0.34 & 0.33 & 0.38 \\
\hline Return on Net Assets Ratio (12.5\%) & 0.06 & 0.38 & 0.38 & -0.13 & -0.13 & -0.10 & -0.13 & -0.13 & 0.38 \\
\hline Net Operating Revenues Ratio (25\%) & 0.44 & 0.75 & 0.75 & -0.25 & -0.25 & 0.08 & 0.48 & 0.62 & 0.75 \\
\hline Risk Factors (25\%) & 0.25 & 0.25 & 0.25 & 0.00 & 0.00 & 0.00 & 0.00 & 0.00 & 0.50 \\
\hline MRA Index (Single Year) & 1.7 & $2.4 \mid$ & 2.5 & 0.5 & \begin{tabular}{l|l|}
-0.2 & \\
\end{tabular} & 0.2 & 0.6 & 0.8 & 2.2 \\
\hline \multicolumn{10}{|l|}{ Primary Reserve Ratio } \\
\hline Unrestricted Net Assets & $\$ 7,427,027$ & $\$ 8,943,552$ & $\$ 10,151,977$ & $\$ 7,533,422$ & $-\$ 1,021,436$ & $-\$ 1,660,410$ & $-\$ 1,230,426$ & $-\$ 482,168$ & $\$ 3,045,446$ \\
\hline Temporarily-restricted Net Assets & $\$ 4,503,892$ & $\$ 4,787,072$ & $\$ 5,920,320$ & $\$ 4,364,554$ & $\$ 4,624,402$ & $\$ 4,991,791$ & $\$ 2,916,950$ & $\$ 2,953,663$ & $\$ 2,704,193$ \\
\hline $\begin{array}{l}\text { Land, Building and Equipment, } \\
\text { net of depreciation }\end{array}$ & $\$ 29,892,710$ & $\$ 29,516,326$ & $\$ 29,305,969$ & $\$ 28,976,101$ & $\$ 27,327,323$ & $\$ 26,200,903$ & $\$ 24,271,984$ & $\$ 23,556,309$ & $\$ 22,546,543$ \\
\hline Long-term Debt & $\$ 24,174,376$ & $\$ 23,404,700$ & $\$ 22,930,232$ & $\$ 23,336,875$ & $\$ 21,258,488$ & $\$ 22,194,098$ & $\$ 21,705,150$ & $\$ 21,440,415$ & $\$ 18,690,407$ \\
\hline Total Expenses & $\$ 26,948,203$ & $\$ 27,639,471$ & $\$ 28,047,364$ & $\$ 30,637,129$ & $\$ 33,104,297$ & $\$ 26,522,828$ & $\$ 28,207,168$ & $\$ 30,806,183$ & $\$ 26,950,825$ \\
\hline Ratio & 0.23 & \begin{tabular}{l|l}
0.28 \\
\end{tabular} & 0.35 & 0.20 & \begin{tabular}{l|l|}
-0.08 \\
\end{tabular} & \begin{tabular}{l|l|}
-0.03 \\
\end{tabular} & \begin{tabular}{l|l|}
-0.04 \\
\end{tabular} & 0.01 & 0.06 \\
\hline Strength Factor & 2.31 & \begin{tabular}{|l|l|}
2.76 \\
\end{tabular} & \begin{tabular}{l|l|l}
3.00 \\
\end{tabular} & 2.04 & \begin{tabular}{l|l}
-0.81 \\
\end{tabular} & -0.33 & \begin{tabular}{|c|}
-0.38 \\
\end{tabular} & 0.06 & 0.64 \\
\hline Weighted Value (25\%) & 0.58 & \begin{tabular}{|c|c|}
0.69 \\
\end{tabular} & 0.75 & 0.51 & -0.20 & -0.08 & -0.10 & 0.01 & 0.16 \\
\hline
\end{tabular}

\begin{tabular}{|c|c|c|c|c|c|c|c|c|c|}
\hline \multicolumn{10}{|l|}{ Equity Ratio } \\
\hline Net Assets & $\$ 28,933,170$ & $\$ 31,299,867$ & $\$ 33,720,891$ & $\$ 29,713,937$ & $\$ 21,504,792$ & $\$ 21,154,886$ & $\$ 19,998,397$ & $\$ 19,198,878$ & $\$ 23,052,435$ \\
\hline Intangible Assets & $\$ 0$ & $\$ 0$ & $\$ 0$ & $\$ 0$ & $\$ 214,310$ & $\$ 207,511$ & $\$ 194,930$ & $\$ 182,349$ & $\$ 169,769$ \\
\hline Unsecured Related-party Receivables & $\$ 0$ & $\$ 0$ & $\$ 0$ & $\$ 0$ & $\$ 0$ & $\$ 0$ & $\$ 0$ & $\$ 0$ & $\$ 0$ \\
\hline Total Assets & $\$ 56,043,200$ & $\$ 56,224,176$ & $\$ 58,267,086$ & $\$ 54,990,421$ & $\$ 45,946,242$ & $\$ 45,403,097$ & $\$ 44,107,770$ & $\$ 43,092,453$ & $\$ 43,870,089$ \\
\hline - Intangible Assets & $\$ 0$ & $\$ 0$ & $\$ 0$ & $\$ 0$ & $\$ 214,310$ & $\$ 207,511$ & $\$ 194,930$ & $\$ 182,349$ & $\$ 169,769$ \\
\hline - Unsecured Related-party Receivables & $\$ 0$ & $\$ 0$ & $\$ 0$ & $\$ 0$ & $\$ 0$ & $\$ 0$ & $\$ 0$ & $\$ 0$ & $\$ 0$ \\
\hline Ratio & 0.52 & \begin{tabular}{l|l|l}
0.56 \\
\end{tabular} & 0.58 & 0.54 & 0.47 & 0.46 & 0.45 & 0.44 & 0.52 \\
\hline Strength Factor & 3.00 & 3.00 & 3.00 & 3.00 & 2.79 & 2.78 & 2.71 & 2.66 & 3.00 \\
\hline Weighted Value (12.5\%) & 0.38 & \begin{tabular}{l|l}
0.38 & 0 \\
\end{tabular} & 0.38 & 0.38 & 0.35 & 0.35 & 0.34 & 0.33 & 0.38 \\
\hline \multicolumn{10}{|l|}{ Return on Net Assets Ratio } \\
\hline$\Delta$ Net Assets & $\$ 294,133$ & $\$ 2,366,697$ & $\$ 2,421,024$ & $-\$ 4,006,954$ & $-\$ 8,209,145$ & $-\$ 349,906$ & $-\$ 1,156,489$ & $-\$ 799,519$ & $\$ 3,853,557$ \\
\hline Total Net Assets (BOY) & $\$ 28,639,037$ & $\$ 28,933,170$ & $\$ 31,299,867$ & $\$ 33,720,891$ & $\$ 29,713,937$ & $\$ 21,504,792$ & $\$ 21,154,886$ & $\$ 19,998,397$ & $\$ 19,198,878$ \\
\hline Ratio & 0.01 & 0.08 & 0.08 & -0.12 & -0.28 & -0.02 & -0.05 & -0.04 & 0.20 \\
\hline Strength Factor & 0.51 & 3.00 & 3.00 & -1.00 & -1.00 & -0.81 & -1.00 & -1.00 & 3.00 \\
\hline Weighted Value (12.5\%) & 0.06 & \begin{tabular}{l|l}
0.38 \\
\end{tabular} & 0.38 & -0.13 & -0.13 & -0.10 & -0.13 & -0.13 & 0.38 \\
\hline \multicolumn{10}{|l|}{ Net Operating Revenues Ratio } \\
\hline$\Delta$ Unrestricted Net Assets & $\$ 294,128$ & $\$ 1,516,525$ & $\$ 1,208,425$ & $-\$ 2,618,555$ & $-\$ 8,554,858$ & $-\$ 638,974$ & $\$ 429,984$ & $\$ 748,258$ & $\$ 3,527,614$ \\
\hline Total Unrestricted Revenue & $\$ 19,819,852$ & $\begin{array}{l}20,499,089 \\
\end{array}$ & $\$ 21,829,042$ & $\$ 22,360,654$ & $\$ 22,953,640$ & $\$ 23,207,576$ & $\$ 23,493,584$ & $\$ 25,431,478$ & $\$ 24,910,309$ \\
\hline Ratio & 0.01 & 0.07 & 0.06 & -0.12 & -0.37 & -0.03 & 0.02 & 0.03 & 0.14 \\
\hline Strength Factor & 1.74 & 3.00 & 3.00 & -1.00 & -1.00 & 0.31 & 1.92 & 2.47 & 3.00 \\
\hline Weighted Value $(25 \%)$ & 0.44 & \begin{tabular}{ll|l}
0.75 \\
\end{tabular} & 0.75 & -0.25 & -0.25 & 0.08 & 0.48 & 0.62 & 0.75 \\
\hline \multicolumn{10}{|l|}{ Risk Factors } \\
\hline $\begin{array}{l}\text { Enrollment } \\
<1,000(2) \text { or }<2,500(1)\end{array}$ & 1047 & 1025 & 1081 & 1044 & 1094 & 1080 & 1013 & 1040 & 1040 \\
\hline $\begin{array}{l}\text { Religious or Non-Degree Granting } \\
\text { yes }\end{array}$ & no & no & no & no & no & no & no & no & no \\
\hline $\begin{array}{l}\text { Ratio of Full-time to Part-time Students } \\
<3.0\end{array}$ & 48.8 & 52.3 & no $\mathrm{P} / \mathrm{T}$ & no $\mathrm{P} / \mathrm{T}$ & no $\mathrm{P} / \mathrm{T}$ & no $\mathrm{P} / \mathrm{T}$ & no $\mathrm{P} / \mathrm{T}$ & 74.3 & no $\mathrm{P} / \mathrm{T}$ \\
\hline $\begin{array}{l}\text { Tuition Discounting } \\
>60 \%\end{array}$ & $27 \%$ & $22 \%$ & $25 \%$ & $27 \%$ & $26 \%$ & $29 \%$ & $34 \%$ & $36 \%$ & $36 \%$ \\
\hline $\begin{array}{l}\text { Tuition Reliance } \\
>85 \%\end{array}$ & $69 \%$ & $74 \%$ & $74 \%$ & $69 \%$ & $72 \%$ & $82 \%$ & $84 \%$ & $73 \%$ & $73 \%$ \\
\hline $\begin{array}{l}\text { Interest Expense } \\
>10 \%\end{array}$ & $3 \%$ & $3 \%$ & $0 \%$ & $3 \%$ & $2 \%$ & $2 \%$ & $2 \%$ & $2 \%$ & $3 \%$ \\
\hline $\begin{array}{l}\text { Net Revenue } \\
<0\end{array}$ & $\$ 851,530$ & $\$ 1,449,848$ & $\$ 1,556,330$ & $-\$ 666,870$ & $-\$ 6,312,787$ & $-\$ 256,889$ & $-\$ 1,654,738$ & $-\$ 172,287$ & $\$ 3,256,667$ \\
\hline $\begin{array}{l}\text { Endowment/Total Budget } \\
<3.0\end{array}$ & 1.23 & 1.31 & 1.22 & 1.39 & 2.31 & 1.76 & 1.71 & 1.85 & 0.00 \\
\hline Total Risk Factors & 2 & 2 & 2 & 3 & 3 & 3 & 3 & 3 & 1 \\
\hline Strength Factor & 1 & 1 & 1 & 0 & 0 & 0 & 0 & 0 & 2 \\
\hline Weighted Value $(25 \%)$ & 0.25 & \begin{tabular}{l|l|}
0.25 \\
\end{tabular} & 0.25 & 0.00 & 0.00 & 0.00 & $\begin{array}{ll}0.00 \\
\end{array}$ & 0.00 & 0.50 \\
\hline
\end{tabular}


MacMurray College

\begin{tabular}{|c|c|c|c|c|c|c|c|c|c|}
\hline Year & 2005 & 2006 & 2007 & 2008 & 2009 & 2010 & 2011 & 2012 & 2013 \\
\hline MRA Composite Index & & & -0.1 & 0.6 & 0.6 & 0.9 & 1.1 & 0.9 & 1.1 \\
\hline FRCS & & & 0.7 & \begin{tabular}{l|l}
1.4 & \\
\end{tabular} & \begin{tabular}{l|l|l}
0.9 & \\
\end{tabular} & 1.4 & 1.4 & 1.0 & 1.4 \\
\hline \multicolumn{10}{|l|}{\begin{tabular}{|l|} 
Index Components \\
\end{tabular}} \\
\hline Primary Reserve Ratio (25\%) & -0.25 & -0.25 & -0.25 & -0.25 & -0.25 & -0.25 & -0.25 & -0.25 & -0.25 \\
\hline Equity Ratio (12.5\%) & 0.38 & 0.38 & 0.38 & 0.38 & 0.38 & 0.38 & 0.38 & 0.38 & 0.38 \\
\hline Return on Net Assets Ratio (12.5\%) & -0.13 & -0.13 & 0.11 & 0.38 & -0.11 & 0.38 & 0.38 & -0.02 & 0.38 \\
\hline Net Operating Revenues Ratio (25\%) & -0.25 & -0.25 & -0.11 & 0.75 & 0.29 & 0.75 & 0.75 & 0.22 & 0.75 \\
\hline Risk Factors (25\%) & 0.00 & 0.00 & 0.00 & 0.00 & 0.00 & 0.00 & 0.00 & 0.25 & 0.25 \\
\hline MRA Index (Single Year) & -0.3 & -0.3 & 0.1 & \begin{tabular}{l|l}
1.3 & \\
\end{tabular} & \begin{tabular}{l|l}
0.3 \\
\end{tabular} & 1.3 & 1.3 & 0.6 & 1.5 \\
\hline \multicolumn{10}{|l|}{ Primary Reserve Ratio } \\
\hline Unrestricted Net Assets & $\$ 1,948,376$ & $-\$ 985,100$ & $-\$ 1,721,832$ & $-\$ 934,879$ & $-\$ 901,175$ & $\$ 753,435$ & $\$ 1,545,620$ & $\$ 1,483,942$ & $\$ 3,707,829$ \\
\hline Temporarily-restricted Net Assets & $\$ 333,443$ & $\$ 234,482$ & $\$ 724,880$ & $\$ 938,677$ & $\$ 757,819$ & $\$ 790,026$ & $\$ 1,251,274$ & $\$ 1,325,579$ & $\$ 1,172,827$ \\
\hline $\begin{array}{l}\text { Land, Building and Equipment, } \\
\text { net of depreciation }\end{array}$ & $\$ 12,118,332$ & $\$ 10,793,260$ & $\$ 10,239,592$ & $\$ 9,867,470$ & $\$ 10,036,635$ & $\$ 9,699,132$ & $\$ 9,737,063$ & $\$ 9,912,705$ & $\$ 10,358,275$ \\
\hline Long-term Debt & $\$ 4,557,933$ & $\$ 3,775,016$ & $\$ 3,492,382$ & $\$ 2,477,326$ & $\$ 2,012,369$ & $\$ 770,447$ & $\$ 1,015,333$ & $\$ 1,419,692$ & $\$ 583,110$ \\
\hline Total Expenses & $\$ 16,752,704$ & $\$ 17,502,728$ & $\$ 15,284,883$ & $\$ 13,343,781$ & $\$ 12,820,866$ & $\$ 11,309,930$ & $\$ 12,400,887$ & $\$ 13,776,988$ & $\$ 14,913,907$ \\
\hline Ratio & -0.32 & \begin{tabular}{l|l|}
-0.44 \\
\end{tabular} & \begin{tabular}{ll|}
-0.51 \\
\end{tabular} & -0.55 & \begin{tabular}{l|l|}
-0.64 \\
\end{tabular} & \begin{tabular}{ll|}
-0.65 \\
\end{tabular} & -0.48 & \begin{tabular}{l|l|}
-0.41 \\
\end{tabular} & -0.33 \\
\hline Strength Factor & -1.00 & -1.00 & -1.00 & $\begin{array}{l}-1.00 \\
\end{array}$ & $\begin{array}{l}-1.00 \\
\end{array}$ & -1.00 & \begin{tabular}{ll|}
-1.00 \\
\end{tabular} & -1.00 & -1.00 \\
\hline Weighted Value (25\%) & -0.25 & -0.25 & -0.25 & -0.25 & -0.25 & -0.25 & -0.25 & -0.25 & -0.25 \\
\hline
\end{tabular}

\begin{tabular}{|c|c|c|c|c|c|c|c|c|c|}
\hline Equity Ratio & & & & & & & & & \\
\hline Net Assets & $\$ 14,901,251$ & $\$ 13,013,311$ & $\$ 13,245,370$ & $\$ 15,044,395$ & $\$ 14,768,343$ & $\$ 16,683,138$ & $\$ 18,086,894$ & $\$ 18,015,160$ & $\$ 20,389,795$ \\
\hline Intangible Assets & $\$ 0$ & $\$ 0$ & $\$ 0$ & $\$ 0$ & $\$ 0$ & $\$ 0$ & $\$ 0$ & $\$ 0$ & $\$ 0$ \\
\hline Unsecured Related-party Receivables & $\$ 0$ & $\$ 0$ & $\$ 0$ & $\$ 0$ & $\$ 0$ & $\$ 0$ & $\$ 0$ & $\$ 0$ & $\$ 0$ \\
\hline Total Assets & $\$ 23,164,591$ & $\$ 20,400,709$ & $\$ 20,301,234$ & $\$ 20,746,977$ & $\$ 20,063,671$ & $\$ 20,635,957$ & $\$ 22,300,487$ & $\$ 22,847,309$ & $\$ 24,689,071$ \\
\hline - Intangible Assets & $\$ 0$ & $\$ 0$ & $\$ 0$ & $\$ 0$ & $\$ 0$ & $\$ 0$ & $\$ 0$ & $\$ 0$ & $\$ 0$ \\
\hline - Unsecured Related-party Receivables & $\$ 0$ & $\$ 0$ & $\$ 0$ & $\$ 0$ & $\$ 0$ & $\$ 0$ & $\$ 0$ & $\$ 0$ & $\$ 0$ \\
\hline Ratio & 0.64 & 0.64 & 0.65 & 0.73 & 0.74 & 0.81 & 0.81 & 0.79 & 0.83 \\
\hline Strength Factor & 3.00 & 3.00 & 3.00 & 3.00 & 3.00 & 3.00 & 3.00 & 3.00 & 3.00 \\
\hline Weighted Value (12.5\%) & 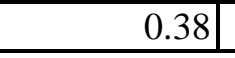 & 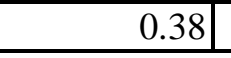 & 0.38 & 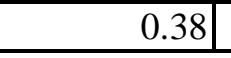 & 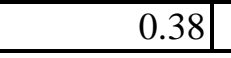 & 0.38 & 0.38 & 0.38 & 0.38 \\
\hline \multicolumn{10}{|l|}{ Return on Net Assets Ratio } \\
\hline$\Delta$ Net Assets & $-\$ 1,113,396$ & $-\$ 1,887,940$ & $\$ 232,059$ & $\$ 1,799,025$ & $-\$ 276,052$ & $\$ 1,914,795$ & $\$ 1,403,756$ & $-\$ 71,734$ & $\$ 2,374,635$ \\
\hline Total Net Assets (BOY) & $\$ 16,014,647$ & $\$ 14,901,251$ & $\$ 13,013,311$ & $\$ 13,245,370$ & $\$ 15,044,395$ & $\$ 14,768,343$ & $\$ 16,683,138$ & $\$ 18,086,894$ & $\$ 18,015,160$ \\
\hline Ratio & -0.07 & -0.13 & 0.02 & 0.14 & -0.02 & 0.13 & 0.08 & 0.00 & 0.13 \\
\hline Strength Factor & -1.00 & -1.00 & 0.89 & 3.00 & -0.92 & 3.00 & 3.00 & -0.20 & 3.00 \\
\hline Weighted Value (12.5\%) & -0.13 & \begin{tabular}{l|l|l}
-0.13 \\
\end{tabular} & 0.11 & $\begin{array}{ll}0.38 \\
\end{array}$ & \begin{tabular}{l|l|l|}
-0.11 & 0 \\
\end{tabular} & 0.38 & 0.38 & -0.02 & 0.38 \\
\hline \multicolumn{10}{|l|}{\begin{tabular}{|l|} 
Net Operating Revenues Ratio \\
\end{tabular}} \\
\hline \begin{tabular}{|l}
$\Delta$ Unrestricted Net Assets \\
\end{tabular} & $-\$ 1,564,896$ & $-\$ 2,933,476$ & $-\$ 736,732$ & $\$ 786,953$ & $\$ 33,704$ & $\$ 1,654,610$ & $\$ 792,185$ & $-\$ 61,678$ & $\$ 2,223,887$ \\
\hline Total Unrestricted Revenue & $\$ 13,338,227$ & $\$ 12,741,604$ & $\$ 12,726,787$ & $\$ 12,141,040$ & $\$ 11,517,836$ & $\$ 10,682,863$ & $\$ 10,360,197$ & $\$ 11,925,201$ & $\$ 13,776,723$ \\
\hline Ratio & \begin{tabular}{l|l|}
-0.12 \\
\end{tabular} & \begin{tabular}{l|l|}
-0.23 \\
\end{tabular} & -0.06 & 0.06 & \begin{tabular}{l|l}
0.00 \\
\end{tabular} & 0.15 & 0.08 & -0.01 & 0.16 \\
\hline Strength Factor & -1.00 & -1.00 & -0.45 & 3.00 & 1.15 & 3.00 & 3.00 & 0.87 & 3.00 \\
\hline Weighted Value (25\%) & -0.25 & -0.25 & -0.11 & 0.75 & \begin{tabular}{l|l}
0.29 \\
\end{tabular} & 0.75 & 0.75 & 0.22 & 0.75 \\
\hline \multicolumn{10}{|l|}{ Risk Factors } \\
\hline $\begin{array}{l}\text { Enrollment } \\
<1,000(2) \text { or }<2,500(1)\end{array}$ & 634 & 664 & 667 & 612 & 564 & 491 & 472 & 502 & 502 \\
\hline $\begin{array}{l}\text { Religious or Non-Degree Granting } \\
\text { yes }\end{array}$ & no & no & no & no & no & no & no & no & no \\
\hline $\begin{array}{l}\text { Ratio of Full-time to Part-time Students } \\
<3.0\end{array}$ & 148.0 & no $P / T$ & no $\mathrm{P} / \mathrm{T}$ & no $P / T$ & no $P / T$ & no $\mathrm{P} / \mathrm{T}$ & no $\mathrm{P} / \mathrm{T}$ & no $\mathrm{P} / \mathrm{T}$ & no $\mathrm{P} / \mathrm{T}$ \\
\hline $\begin{array}{l}\text { Tuition Discounting } \\
>60 \%\end{array}$ & $36 \%$ & $36 \%$ & $34 \%$ & $29 \%$ & $29 \%$ & $30 \%$ & $29 \%$ & $30 \%$ & $30 \%$ \\
\hline $\begin{array}{l}\text { Tuition Reliance } \\
>85 \%\end{array}$ & $68 \%$ & $77 \%$ & $84 \%$ & $84 \%$ & $84 \%$ & $77 \%$ & $71 \%$ & $82 \%$ & $82 \%$ \\
\hline $\begin{array}{l}\text { Interest Expense } \\
>10 \%\end{array}$ & $1 \%$ & $1 \%$ & $1 \%$ & $1 \%$ & $1 \%$ & $0 \%$ & $0 \%$ & $0 \%$ & $0 \%$ \\
\hline $\begin{array}{l}\text { Net Revenue } \\
<0\end{array}$ & $-\$ 1,106,036$ & $-\$ 1,655,744$ & $\$ 103,048$ & $\$ 1,867,059$ & $\$ 630,416$ & $\$ 1,552,970$ & $\$ 802,427$ & $\$ 187,240$ & $\$ 1,620,002$ \\
\hline $\begin{array}{l}\text { Endowment/Total Budget } \\
<3.0\end{array}$ & 3.59 & 3.28 & 2.70 & 1.88 & 2.01 & 2.01 & 2.63 & 3.58 & 0.00 \\
\hline Total Risk Factors & \begin{tabular}{l|l}
3 \\
\end{tabular} & $3 \mid$ & 3 & 3 & $3 \mid$ & 3 & 3 & 2 & 2 \\
\hline Strength Factor & 0 & 0 & 0 & 0 & 0 & 0 & 0 & 1 & 1 \\
\hline Weighted Value (25\%) & \begin{tabular}{l|l}
0.00 & \\
\end{tabular} & \begin{tabular}{l|l}
0.00 \\
\end{tabular} & 0.00 & \begin{tabular}{l|l}
0.00 \\
\end{tabular} & \begin{tabular}{l|l}
0.00 \\
\end{tabular} & 0.00 & 0.00 & 0.25 & 0.25 \\
\hline
\end{tabular}


Ohio Valley University

\begin{tabular}{|c|c|c|c|c|c|c|c|c|c|}
\hline Year & 2005 & 2006 & 2007 & 2008 & 2009 & 2010 & 2011 & 2012 & 2013 \\
\hline MRA Composite Index & & & 1.2 & 0.9 & 0.7 & 0.3 & 0.2 & 0.4 & 0.9 \\
\hline FRCS & & & 0.7 & 0.6 & -0.6 & -0.8 & -0.1 & -0.8 & 0.1 \\
\hline \multicolumn{10}{|l|}{ Index Components } \\
\hline \begin{tabular}{|l} 
Primary Reserve Ratio (25\%) \\
\end{tabular} & 0.75 & 0.61 & 0.75 & 0.75 & 0.75 & 0.75 & 0.75 & 0.75 & 0.75 \\
\hline Equity Ratio (12.5\%) & 0.15 & 0.08 & 0.08 & 0.11 & 0.10 & 0.01 & -0.01 & -0.04 & 0.01 \\
\hline Return on Net Assets Ratio (12.5\%) & 0.38 & -0.13 & 0.38 & 0.38 & -0.13 & -0.13 & -0.13 & 0.38 & -0.13 \\
\hline Net Operating Revenues Ratio (25\%) & 0.75 & -0.25 & 0.75 & -0.25 & -0.19 & -0.25 & -0.24 & -0.25 & 0.75 \\
\hline Risk Factors (25\%) & 0.00 & -0.25 & -0.25 & -0.25 & -0.25 & -0.25 & -0.25 & -0.25 & 0.00 \\
\hline MRA Index (Single Year) & 2.0 & 0.1 & 1.7 & 0.7 & 0.3 & 0.1 & 0.1 & 0.6 & 1.4 \\
\hline \multicolumn{10}{|l|}{ Primary Reserve Ratio } \\
\hline Unrestricted Net Assets & $\$ 1,646,450$ & $-\$ 454,550$ & $\$ 1,613,111$ & $-\$ 1,143,570$ & $-\$ 1,560,943$ & $-\$ 3,131,501$ & $-\$ 3,580,535$ & $-\$ 4,514,509$ & $-\$ 3,205,453$ \\
\hline Temporarily-restricted Net Assets & $\$ 1,582,107$ & $\$ 1,613,111$ & $\$ 1,887,939$ & $\$ 3,773,863$ & $\$ 3,707,156$ & $\$ 2,138,955$ & $\$ 1,916,063$ & $\$ 2,021,949$ & $\$ 2,115,128$ \\
\hline $\begin{array}{l}\text { Land, Building and Equipment, } \\
\text { net of depreciation }\end{array}$ & $\$ 16,261,331$ & $\$ 15,916,728$ & $\$ 16,781,824$ & $\$ 16,297,722$ & $\$ 15,870,968$ & $\$ 15,558,198$ & $\$ 15,101,235$ & $\$ 15,043,460$ & $\$ 15,258,494$ \\
\hline Long-term Debt & $\$ 15,965,101$ & $\$ 17,251,724$ & $\$ 18,567,853$ & $\$ 20,265,869$ & $\$ 20,537,861$ & $\$ 22,388,142$ & $\$ 22,681,339$ & $\$ 23,655,475$ & $\$ 23,477,578$ \\
\hline Total Expenses & $\$ 8,978,391$ & $\$ 10,231,713$ & $\$ 10,909,630$ & $\$ 10,323,613$ & $\$ 10,522,457$ & $\$ 10,328,343$ & $\$ 9,237,435$ & $\$ 9,937,122$ & $\$ 8,498,005$ \\
\hline Ratio & 0.33 & 0.24 & 0.48 & 0.64 & 0.65 & 0.57 & 0.64 & 0.62 & 0.84 \\
\hline Strength Factor & 3.00 & 2.44 & 3.00 & 3.00 & 3.00 & 3.00 & 3.00 & 3.00 & 3.00 \\
\hline Weighted Value (25\%) & 0.75 & 0.61 & 0.75 & 0.75 & 0.75 & 0.75 & 0.75 & 0.75 & 0.75 \\
\hline \multicolumn{10}{|l|}{ Equity Ratio } \\
\hline Net Assets & $\$ 4,194,293$ & $\$ 2,151,388$ & $\$ 2,286,420$ & $\$ 3,822,204$ & $\$ 3,338,544$ & $\$ 215,098$ & $-\$ 378,483$ & $-\$ 1,201,666$ & $\$ 326,270$ \\
\hline Intangible Assets & $\$ 0$ & $\$ 0$ & $\$ 0$ & $\$ 0$ & $\$ 0$ & $\$ 0$ & $\$ 0$ & $\$ 0$ & $\$ 0$ \\
\hline Unsecured Related-party Receivables & $\$ 0$ & $\$ 0$ & $\$ 0$ & $\$ 0$ & $\$ 0$ & $\$ 0$ & $\$ 0$ & $\$ 0$ & $\$ 0$ \\
\hline Total Assets & $\$ 21,061,691$ & $\$ 20,426,833$ & $\$ 21,579,648$ & $\$ 25,097,324$ & $\$ 24,819,835$ & $\$ 23,526,571$ & $\$ 23,358,197$ & $\$ 23,745,800$ & $\$ 25,007,359$ \\
\hline - Intangible Assets & $\$ 0$ & $\$ 0$ & $\$ 0$ & $\$ 0$ & $\$ 0$ & $\$ 0$ & $\$ 0$ & $\$ 0$ & $\$ 0$ \\
\hline - Unsecured Related-party Receivables & $\$ 0$ & $\$ 0$ & $\$ 0$ & $\$ 0$ & $\$ 0$ & $\$ 0$ & $\$ 0$ & $\$ 0$ & $\$ 0$ \\
\hline Ratio & 0.20 & 0.11 & 0.11 & 0.15 & 0.13 & 0.01 & -0.02 & -0.05 & 0.01 \\
\hline Strength Factor & 1.19 & 0.63 & 0.64 & 0.91 & 0.81 & 0.05 & -0.10 & -0.30 & 0.08 \\
\hline Weighted Value (12.5\%) & 0.15 & 0.08 & 0.08 & 0.11 & 0.10 & 0.01 & -0.01 & \begin{tabular}{ll|}
-0.04 \\
\end{tabular} & 0.01 \\
\hline \multicolumn{10}{|l|}{ Return on Net Assets Ratio } \\
\hline$\Delta$ Net Assets & $\$ 316,514$ & $-\$ 2,042,905$ & $\$ 135,032$ & $\$ 1,535,784$ & $-\$ 483,660$ & $-\$ 3,123,446$ & $-\$ 593,581$ & $-\$ 823,183$ & $\$ 1,527,936$ \\
\hline Total Net Assets (BOY) & $\$ 3,877,779$ & $\$ 4,194,293$ & $\$ 2,151,388$ & $\$ 2,286,420$ & $\$ 3,822,204$ & $\$ 3,338,544$ & $\$ 215,098$ & $-\$ 378,483$ & $-\$ 1,201,666$ \\
\hline Ratio & 0.08 & -0.49 & 0.06 & 0.67 & -0.13 & -0.94 & -2.76 & 2.17 & -1.27 \\
\hline Strength Factor & 3.00 & -1.00 & 3.00 & 3.00 & -1.00 & -1.00 & -1.00 & 3.00 & -1.00 \\
\hline Weighted Value (12.5\%) & 0.38 & -0.13 & 0.38 & 0.38 & -0.13 & -0.13 & -0.13 & 0.38 & -0.13 \\
\hline \multicolumn{10}{|l|}{\begin{tabular}{|l|} 
Net Operating Revenues Ratio \\
\end{tabular}} \\
\hline$\Delta$ Unrestricted Net Assets & $\$ 378,766$ & $-\$ 2,101,000$ & $\$ 2,067,661$ & $-\$ 2,756,681$ & $-\$ 417,373$ & $-\$ 1,570,558$ & $-\$ 449,034$ & $-\$ 933,974$ & $\$ 1,309,056$ \\
\hline Total Unrestricted Revenue & $\$ 6,084,583$ & $\$ 5,956,668$ & $\$ 6,218,343$ & $\$ 6,812,967$ & $\$ 5,879,690$ & $\$ 5,877,757$ & $\$ 5,681,596$ & $\$ 5,759,890$ & $\$ 5,570,980$ \\
\hline Ratio & 0.06 & -0.35 & 0.33 & -0.40 & -0.07 & -0.27 & -0.08 & -0.16 & 0.23 \\
\hline Strength Factor & 3.00 & -1.00 & 3.00 & -1.00 & -0.77 & -1.00 & -0.98 & -1.00 & 3.00 \\
\hline Weighted Value (25\%) & 0.75 & -0.25 & 0.75 & -0.25 & \begin{tabular}{ll|}
-0.19 \\
\end{tabular} & -0.25 & -0.24 & -0.25 & 0.75 \\
\hline \multicolumn{10}{|l|}{ Risk Factors } \\
\hline $\begin{array}{l}\text { Enrollment } \\
<1,000(2) \text { or }<2,500(1)\end{array}$ & 491 & 519 & 500 & 524 & 476 & 449 & 423 & 480 & 480 \\
\hline $\begin{array}{l}\text { Religious or Non-Degree Granting } \\
\text { yes }\end{array}$ & yes & yes & yes & yes & yes & yes & yes & yes & yes \\
\hline $\begin{array}{l}\text { Ratio of Full-time to Part-time Students } \\
<3.0\end{array}$ & 95.0 & 102.0 & no $P / T$ & 107.0 & no $\mathrm{P} / \mathrm{T}$ & 42.0 & no $\mathrm{P} / \mathrm{T}$ & no $\mathrm{P} / \mathrm{T}$ & no $\mathrm{P} / \mathrm{T}$ \\
\hline $\begin{array}{l}\text { Tuition Discounting } \\
>60 \%\end{array}$ & $27 \%$ & $32 \%$ & $32 \%$ & $33 \%$ & $39 \%$ & $39 \%$ & $43 \%$ & $51 \%$ & $51 \%$ \\
\hline $\begin{array}{l}\text { Tuition Reliance } \\
>85 \%\end{array}$ & $56 \%$ & $66 \%$ & $59 \%$ & $51 \%$ & $56 \%$ & $67 \%$ & $55 \%$ & $48 \%$ & $48 \%$ \\
\hline $\begin{array}{l}\text { Interest Expense } \\
>10 \%\end{array}$ & $6 \%$ & $10 \%$ & $13 \%$ & $12 \%$ & $15 \%$ & $16 \%$ & $17 \%$ & $16 \%$ & $0 \%$ \\
\hline $\begin{array}{l}\text { Net Revenue } \\
<0\end{array}$ & $\$ 316,514$ & $-\$ 2,042,905$ & $\$ 235,032$ & $\$ 1,435,784$ & $-\$ 1,269,942$ & $-\$ 1,585,797$ & $-\$ 123,363$ & $-\$ 171,039$ & $\$ 2,747,323$ \\
\hline $\begin{array}{l}\text { Endowment/Total Budget } \\
<3.0\end{array}$ & 6.45 & 6.87 & 6.77 & 3.60 & 4.87 & 4.26 & 3.39 & 5.25 & 0.00 \\
\hline Total Risk Factors & 3 & 5 & 4 & 4 & 5 & 5 & 5 & 5 & 3 \\
\hline Strength Factor & 0 & -1 & -1 & -1 & -1 & -1 & -1 & -1 & 0 \\
\hline Weighted Value (25\%) & 0.00 & -0.25 & -0.25 & -0.25 & -0.25 & -0.25 & -0.25 & -0.25 & 0.00 \\
\hline
\end{tabular}


Olivet College

\begin{tabular}{|c|c|c|c|c|c|c|c|c|c|}
\hline Year & 2005 & 2006 & 2007 & 2008 & 2009 & 2010 & 2011 & \begin{tabular}{|c|c|}
2012 & \\
\end{tabular} & 2013 \\
\hline MRA Composite Index & & & 1.4 & 1.8 & \begin{tabular}{c|c}
0.8 \\
\end{tabular} & \begin{tabular}{c|c}
1.0 & \\
\end{tabular} & \begin{tabular}{l|l}
1.1 & \\
\end{tabular} & \begin{tabular}{c|c|}
1.2 & \\
\end{tabular} & 1.4 \\
\hline FRCS & & & $1.5 \mid$ & 1.4 & 0.7 & 1.4 & 1.4 & 1.3 & 1.4 \\
\hline \multicolumn{10}{|l|}{ Index Components } \\
\hline Primary Reserve Ratio (25\%) & -0.03 & 0.27 & \begin{tabular}{l|l|l|l|}
0.67 \\
\end{tabular} & 0.75 & \begin{tabular}{c|}
-0.05 \\
\end{tabular} & -0.06 & 0.10 & 0.12 & 0.16 \\
\hline Equity Ratio $(12.5 \%)$ & 0.35 & 0.36 & 0.38 & 0.38 & 0.37 & 0.38 & 0.38 & 0.38 & 0.38 \\
\hline Return on Net Assets Ratio (12.5\%) & -0.13 & 0.36 & 0.38 & 0.20 & -0.13 & 0.38 & 0.38 & 0.36 & 0.38 \\
\hline Net Operating Revenues Ratio (25\%) & 0.07 & 0.65 & 0.38 & 0.75 & -0.06 & 0.75 & 0.75 & 0.51 & 0.75 \\
\hline Risk Factors (25\%) & -0.25 & 0.00 & 0.00 & -0.25 & -0.25 & 0.00 & -0.25 & -0.25 & 0.00 \\
\hline MRA Index (Single Year) & 0.0 & 1.6 & 1.8 & 1.8 & -0.1 & 1.4 & \begin{tabular}{l|l}
1.3 & \\
\end{tabular} & 1.1 & 1.7 \\
\hline \multicolumn{10}{|l|}{ Primary Reserve Ratio } \\
\hline Unrestricted Net Assets & $\$ 1,471,378$ & $\$ 2,151,990$ & $\$ 2,373,487$ & $\$ 6,108,617$ & $\$ 4,860,387$ & $\$ 8,579,813$ & $\$ 11,451,845$ & $\$ 11,992,703$ & $\$ 13,837,948$ \\
\hline Temporarily-restricted Net Assets & $\$ 2,041,988$ & $\$ 2,037,237$ & $\$ 5,470,241$ & $\$ 2,486,357$ & $\$ 1,156,253$ & $\$ 1,096,437$ & $\$ 1,046,650$ & $\$ 1,956,529$ & $\$ 1,513,819$ \\
\hline $\begin{array}{l}\text { Land, Building and Equipment, } \\
\text { net of depreciation }\end{array}$ & $\$ 16,878,224$ & $\$ 17,271,423$ & $\$ 18,557,004$ & $\$ 16,297,722$ & $\$ 23,466,998$ & $\$ 25,000,590$ & $\$ 24,962,448$ & $\$ 24,556,523$ & $\$ 25,617,753$ \\
\hline Long-term Debt & $\$ 13,071,710$ & $\$ 15,563,317$ & $\$ 17,073,906$ & $\$ 16,193,149$ & $\$ 16,948,208$ & $\$ 14,733,109$ & $\$ 13,484,314$ & $\$ 11,910,400$ & $\$ 12,078,388$ \\
\hline Total Expenses & $\$ 22,757,352$ & $\$ 23,136,372$ & $\$ 23,869,762$ & $\$ 23,918,927$ & $\$ 26,441,153$ & $\$ 25,346,717$ & $\$ 26,270,190$ & $\$ 26,671,155$ & $\$ 28,075,739$ \\
\hline Ratio & -0.01 & 0.11 & 0.27 & 0.35 & \begin{tabular}{l|l|}
-0.02 \\
\end{tabular} & 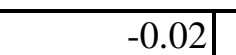 & 0.04 & 0.05 & 0.06 \\
\hline Strength Factor & \begin{tabular}{|c|}
-0.13 \\
\end{tabular} & 1.07 & 2.66 & 3.00 & \begin{tabular}{l|l}
-0.19 \\
\end{tabular} & \begin{tabular}{l|l}
-0.23 & -100 \\
\end{tabular} & \begin{tabular}{l|l}
0.39 \\
\end{tabular} & \begin{tabular}{l|l}
0.49 \\
\end{tabular} & 0.65 \\
\hline \begin{tabular}{|l} 
Weighted Value (25\%) \\
\end{tabular} & -0.03 & \begin{tabular}{l|l}
0.27 & -200 \\
\end{tabular} & 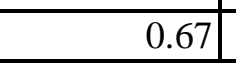 & 0.75 & -0.05 & -0.06 & \begin{tabular}{l|l}
0.10 & \\
\end{tabular} & 0.12 & 0.16 \\
\hline \multicolumn{10}{|l|}{ Equity Ratio } \\
\hline Net Assets & $\$ 15,607,146$ & $\$ 16,497,385$ & $\$ 20,570,226$ & $\$ 21,232,884$ & $\$ 18,345,239$ & $\$ 22,335,876$ & $\$ 25,668,253$ & $\$ 27,143,114$ & $\$ 28,917,202$ \\
\hline Intangible Assets & $\$ 0$ & $\$ 0$ & $\$ 0$ & $\$ 0$ & $\$ 0$ & $\$ 0$ & $\$ 0$ & $\$ 0$ & $\$ 0$ \\
\hline Unsecured Related-party Receivables & $\$ 0$ & $\$ 0$ & $\$ 0$ & $\$ 0$ & $\$ 1,000,000$ & $\$ 0$ & $\$ 0$ & $\$ 0$ & $\$ 0$ \\
\hline Total Assets & $\$ 32,973,418$ & $\$ 33,985,100$ & $\$ 38,986,894$ & $\$ 39,597,457$ & $\$ 36,410,035$ & $\$ 38,459,549$ & $\$ 40,171,944$ & $\$ 40,006,194$ & $\$ 42,083,362$ \\
\hline - Intangible Assets & $\$ 0$ & $\$ 0$ & $\$ 0$ & $\$ 0$ & $\$ 0$ & $\$ 0$ & $\$ 0$ & $\$ 0$ & $\$ 0$ \\
\hline \begin{tabular}{|l} 
- Unsecured Related-party Receivables \\
\end{tabular} & $\$ 0$ & $\$ 0$ & $\$ 0$ & $\$ 0$ & $\$ 1,000,000$ & $\$ 0 \mid$ & $\$ 0$ & $\$ 0$ & $\$ 0$ \\
\hline Ratio & 0.47 & 0.49 & 0.53 & 0.54 & 0.49 & 0.58 & $0.64 \mid$ & \begin{tabular}{l|l}
0.68 \\
\end{tabular} & 0.69 \\
\hline Strength Factor & 2.84 & 2.91 & 3.00 & 3.00 & 2.94 & 3.00 & 3.00 & 3.00 & 3.00 \\
\hline Weighted Value $(12.5 \%)$ & 0.35 & 0.36 & 0.38 & 0.38 & 0.37 & \begin{tabular}{l|l}
0.38 \\
\end{tabular} & \begin{tabular}{l|l}
0.38 \\
\end{tabular} & \begin{tabular}{l|l}
0.38 \\
\end{tabular} & 0.38 \\
\hline \multicolumn{10}{|l|}{ Return on Net Assets Ratio } \\
\hline$\Delta$ Net Assets & $-\$ 957,959$ & $\$ 890,239$ & $\$ 4,072,841$ & $\$ 662,658$ & $-\$ 2,887,645$ & $\$ 3,990,637$ & $\$ 3,332,377$ & $\$ 1,474,861$ & $\$ 1,774,088$ \\
\hline Total Net Assets (BOY) & $\$ 16,565,105$ & $\$ 15,607,146$ & $\$ 16,497,385$ & $\$ 20,570,226$ & $\$ 21,232,884$ & $\$ 18,345,239$ & $\$ 22,335,876$ & $\$ 25,668,253$ & $\$ 27,143,114$ \\
\hline Ratio & -0.06 & \begin{tabular}{l|l|l|}
0.06 \\
\end{tabular} & 0.25 & \begin{tabular}{l|l}
0.03 \\
\end{tabular} & -0.14 & 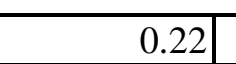 & \begin{tabular}{l|l}
0.15 \\
\end{tabular} & \begin{tabular}{l|l|l|}
0.06 \\
\end{tabular} & 0.07 \\
\hline Strength Factor & -1.00 & 2.85 & 3.00 & 1.61 & \begin{tabular}{l|l}
-1.00 \\
\end{tabular} & 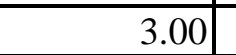 & 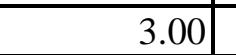 & 2.87 & 3.00 \\
\hline Weighted Value (12.5\%) & -0.13 & 0.36 & 0.38 & 0.20 & \begin{tabular}{c|c|c|c|}
-0.13 \\
\end{tabular} & 0.38 & 0.38 & 0.36 & 0.38 \\
\hline \multicolumn{10}{|l|}{ Net Operating Revenues Ratio } \\
\hline$\Delta$ Unrestricted Net Assets & $-\$ 547,899$ & $\$ 680,612$ & $\$ 221,497$ & $\$ 3,735,130$ & $-\$ 1,248,230$ & $\$ 3,719,426$ & $\$ 2,872,032$ & $\$ 540,858$ & $\$ 1,845,245$ \\
\hline Total Unrestricted Revenue & $\$ 19,542,961$ & $\$ 21,283,512$ & $\$ 21,951,146$ & $\$ 21,797,619$ & $\$ 24,901,152$ & $\$ 25,575,731$ & $\$ 26,187,410$ & $\$ 25,713,417$ & $\$ 27,161,173$ \\
\hline Ratio & -0.03 & \begin{tabular}{l|l}
0.03 \\
\end{tabular} & 0.01 & 0.17 & $\begin{array}{l}-0.05 \\
\end{array}$ & 0.15 & 0.11 & 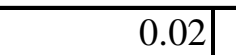 & 0.07 \\
\hline Strength Factor & 0.30 & 2.60 & 1.50 & 3.00 & -0.25 & 3.00 & 3.00 & 2.05 & 3.00 \\
\hline \begin{tabular}{|l} 
Weighted Value $(25 \%)$ \\
\end{tabular} & 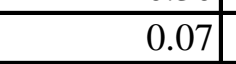 & \begin{tabular}{l|l}
0.65 \\
\end{tabular} & 0.38 & 0.75 & 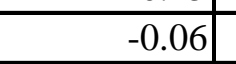 & 0.75 & 0.75 & \begin{tabular}{l|l}
0.51 \\
\end{tabular} & 0.75 \\
\hline \multicolumn{10}{|l|}{ Risk Factors } \\
\hline $\begin{array}{l}\text { Enrollment } \\
<1,000(2) \text { or }<2,500(1)\end{array}$ & 988 & 1064 & 1021 & 978 & 1114 & 1100 & 1081 & 983 & 983 \\
\hline $\begin{array}{l}\text { Religious or Non-Degree Granting } \\
\text { yes }\end{array}$ & yes & yes & yes & yes & yes & yes & yes & yes & yes \\
\hline $\begin{array}{l}\text { Ratio of Full-time to Part-time Students } \\
<3.0\end{array}$ & 190.0 & no $\mathrm{P} / \mathrm{T}$ & no $P / T$ & 209.0 & no $\mathrm{P} / \mathrm{T}$ & 94.0 & 33.4 & no $\mathrm{P} / \mathrm{T}$ & no $P / T$ \\
\hline $\begin{array}{l}\text { Tuition Discounting } \\
>60 \%\end{array}$ & $45 \%$ & $46 \%$ & $45 \%$ & $42 \%$ & $41 \%$ & $42 \%$ & $42 \%$ & $42 \%$ & $42 \%$ \\
\hline $\begin{array}{l}\text { Tuition Reliance } \\
>85 \%\end{array}$ & $82 \%$ & $81 \%$ & $71 \%$ & $68 \%$ & $89 \%$ & $79 \%$ & $87 \%$ & $83 \%$ & $83 \%$ \\
\hline $\begin{array}{l}\text { Interest Expense } \\
>10 \%\end{array}$ & $3 \%$ & $3 \%$ & $3 \%$ & $3 \%$ & $6 \%$ & $2 \%$ & $2 \%$ & $2 \%$ & $1 \%$ \\
\hline $\begin{array}{l}\text { Net Revenue } \\
<0\end{array}$ & $-\$ 778,717$ & $\$ 1,155,149$ & $\$ 3,162,397$ & $\$ 2,871,810$ & $-\$ 1,909,275$ & $\$ 3,484,203$ & $\$ 2,023,370$ & $\$ 1,839,156$ & $\$ 894,104$ \\
\hline $\begin{array}{l}\text { Endowment/Total Budget } \\
<3.0\end{array}$ & 1.81 & 1.76 & 1.60 & 1.94 & 2.87 & 2.46 & 2.18 & 2.25 & 0.00 \\
\hline Total Risk Factors & 5 & $3 \mid$ & 3 & 4 & $5 \mid$ & $3 \mid$ & 4 & 4 & 3 \\
\hline \begin{tabular}{|l|} 
Strength Factor \\
\end{tabular} & -1 & 0 & 0 & \begin{tabular}{l|l}
-1 & \\
\end{tabular} & \begin{tabular}{c|c}
-1 & \\
\end{tabular} & 0 & \begin{tabular}{|l|l}
-1 & \\
\end{tabular} & \begin{tabular}{|l|l}
-1 & \\
\end{tabular} & 0 \\
\hline Weighted Value (25\%) & -0.25 & \begin{tabular}{l|l}
0.00 \\
\end{tabular} & 0.00 & -0.25 & -0.25 & \begin{tabular}{l|l}
0.00 \\
\end{tabular} & -0.25 & -0.25 & 0.00 \\
\hline
\end{tabular}




\section{Rochester College}

\begin{tabular}{|c|c|c|c|c|c|c|c|c|c|}
\hline Year & 2005 & 2006 & 2007 & 2008 & 2009 & 2010 & 2011 & 2012 & 2013 \\
\hline MRA Composite Index & & & 0.1 & -0.3 & -0.1 & -0.1 & -0.2 & -0.1 & 0.1 \\
\hline FRCS & & & \begin{tabular}{ll|}
-0.4 \\
\end{tabular} & \begin{tabular}{ll|}
-0.8 \\
\end{tabular} & \begin{tabular}{ll|}
-1.0 \\
\end{tabular} & -1.0 & -0.6 & $\begin{array}{ll}-0.3 \\
\end{array}$ & -0.6 \\
\hline \multicolumn{10}{|l|}{ Index Components } \\
\hline Primary Reserve Ratio (25\%) & 0.68 & 0.68 & 0.30 & 0.28 & 0.08 & 0.03 & 0.04 & 0.04 & 0.08 \\
\hline Equity Ratio (12.5\%) & 0.25 & 0.18 & 0.06 & -0.13 & -0.13 & \begin{tabular}{c|c|c|}
-0.13 \\
\end{tabular} & \begin{tabular}{|c|c|c|}
-0.13 \\
\end{tabular} & \begin{tabular}{c|c|c|}
-0.13 \\
\end{tabular} & -0.13 \\
\hline Return on Net Assets Ratio (12.5\%) & -0.13 & -0.13 & -0.13 & \begin{tabular}{|c|}
-0.13 \\
\end{tabular} & 0.38 & 0.38 & -0.13 & -0.13 & 0.37 \\
\hline Net Operating Revenues Ratio (25\%) & 0.21 & -0.25 & -0.25 & -0.25 & 0.08 & -0.25 & 0.20 & 0.58 & 0.21 \\
\hline Risk Factors (25\%) & -0.25 & -0.25 & -0.25 & -0.25 & \begin{tabular}{l|l}
-0.25 \\
\end{tabular} & \begin{tabular}{l|l}
-0.25 \\
\end{tabular} & -0.25 & $\begin{array}{ll}-0.25 \\
\end{array}$ & -0.25 \\
\hline MRA Index (Single Year) & 0.8 & 0.2 & $\begin{array}{ll}-0.3 \\
\end{array}$ & \begin{tabular}{r|}
-0.5 \\
\end{tabular} & \begin{tabular}{l|l}
0.2 \\
\end{tabular} & \begin{tabular}{l|l|}
-0.2 \\
\end{tabular} & $\begin{array}{ll}-0.3 \\
\end{array}$ & $\begin{array}{ll}0.1 \\
\end{array}$ & 0.3 \\
\hline \multicolumn{10}{|l|}{ Primary Reserve Ratio } \\
\hline Unrestricted Net Assets & $\$ 4,904,037$ & $\$ 3,640,283$ & $-\$ 579,759$ & $-\$ 5,713,105$ & $-\$ 6,052,221$ & $-\$ 7,861,593$ & $-\$ 7,980,407$ & $-\$ 7,590,327$ & $-\$ 7,694,442$ \\
\hline Temporarily-restricted Net Assets & $\$ 2,888,510$ & $\$ 2,629,339$ & $\$ 2,028,427$ & $\$ 2,622,064$ & $\$ 527,896$ & $\$ 351,454$ & $\$ 574,763$ & $\$ 449,443$ & $\$ 262,846$ \\
\hline $\begin{array}{l}\text { - Land, Building and Equipment, } \\
\text { net of depreciation }\end{array}$ & $\$ 19,526,959$ & $\$ 20,667,616$ & $\$ 19,695,661$ & $\$ 18,873,800$ & $\$ 18,254,167$ & $\$ 17,610,702$ & $\$ 16,976,632$ & $\$ 16,573,727$ & $\$ 15,942,481$ \\
\hline Long-term Debt & $\$ 15,716,038$ & $\$ 18,911,636$ & $\$ 20,157,846$ & $\$ 24,103,891$ & $\$ 24,434,693$ & $\$ 25,457,071$ & $\$ 24,714,046$ & $\$ 24,063,176$ & $\$ 24,113,785$ \\
\hline Total Expenses & $\$ 14,589,860$ & $\$ 16,492,553$ & $\$ 15,997,845$ & $\$ 17,774,031$ & $\$ 16,357,672$ & $\$ 15,376,619$ & $\$ 16,307,120$ & $\$ 16,760,116$ & $\$ 17,743,984$ \\
\hline Ratio & 0.27 & 0.27 & 0.12 & 0.11 & 0.03 & 0.01 & 0.01 & 0.02 & 0.03 \\
\hline \begin{tabular}{|l|} 
Strength Factor \\
\end{tabular} & 2.73 & 2.74 & 1.19 & 1.11 & 0.31 & 0.13 & 0.15 & 0.17 & 0.33 \\
\hline Weighted Value (25\%) & 0.68 & 0.68 & 0.30 & 0.28 & 0.08 & 0.03 & 0.04 & 0.04 & 0.08 \\
\hline \multicolumn{10}{|l|}{ Equity Ratio } \\
\hline Net Assets & $\$ 8,145,934$ & $\$ 6,635,884$ & $\$ 1,821,724$ & $-\$ 911,178$ & $-\$ 3,044,086$ & $-\$ 5,026,198$ & $-\$ 4,754,586$ & $-\$ 4,448,583$ & $-\$ 4,710,531$ \\
\hline Intangible Assets & $\$ 0$ & $\$ 0$ & $\$ 0$ & $\$ 171,755$ & $\$ 146,962$ & $\$ 131,642$ & $\$ 91,740$ & $\$ 56,933$ & $\$ 149,068$ \\
\hline Unsecured Related-party Receivables & $\$ 0$ & $\$ 0$ & $\$ 0$ & $\$ 20,840,764$ & $\$ 21,172,764$ & $\$ 1,656,000$ & $\$ 1,118,207$ & $\$ 700,690$ & $\$ 360,406$ \\
\hline Total Assets & $\$ 24,838,597$ & $\$ 26,950,683$ & $\$ 23,227,749$ & $\$ 23,292,066$ & $\$ 22,060,896$ & $\$ 21,233,461$ & $\$ 20,625,232$ & $\$ 20,692,551$ & $\$ 20,342,340$ \\
\hline - Intangible Assets & $\$ 0$ & $\$ 0$ & $\$ 0$ & $\$ 171,755$ & $\$ 146,962$ & $\$ 131,642$ & $\$ 91,740$ & $\$ 56,933$ & $\$ 149,068$ \\
\hline - Unsecured Related-party Receivables & $\$ 0$ & $\$ 0$ & $\$ 0$ & $\$ 20,840,764$ & $\$ 21,172,764$ & $\$ 1,656,000$ & $\$ 1,118,207$ & $\$ 700,690$ & $\$ 360,406$ \\
\hline Ratio & 0.33 & 0.25 & 0.08 & -9.62 & $\mid-32.87$ & -0.35 & -0.31 & -0.26 & -0.26 \\
\hline Strength Factor & 1.97 & 1.48 & 0.47 & -1.00 & -1.00 & $\begin{array}{ll}-1.00 \\
\end{array}$ & -1.00 & -1.00 & -1.00 \\
\hline Weighted Value (12.5\%) & 0.25 & 0.18 & 0.06 & \begin{tabular}{|c|c|}
-0.13 \\
\end{tabular} & \begin{tabular}{ll|l}
-0.13 \\
\end{tabular} & -0.13 & $\begin{array}{ll}-0.13 \\
\end{array}$ & \begin{tabular}{ll|}
-0.13 \\
\end{tabular} & -0.13 \\
\hline \multicolumn{10}{|l|}{ Return on Net Assets Ratio } \\
\hline$\Delta$ Net Assets & $-\$ 2,461,322$ & $-\$ 1,510,050$ & $-\$ 4,814,160$ & $-\$ 2,732,902$ & $-\$ 2,132,908$ & $-\$ 1,982,112$ & $\$ 271,612$ & $\$ 306,003$ & $-\$ 261,948$ \\
\hline Total Net Assets (BOY) & $\$ 10,607,256$ & $\$ 8,145,934$ & $\$ 6,635,884$ & $\$ 1,821,724$ & $-\$ 911,178$ & $-\$ 3,044,086$ & $-\$ 5,026,198$ & $-\$ 4,754,586$ & $-\$ 4,448,583$ \\
\hline Ratio & -0.23 & \begin{tabular}{|c|}
-0.19 \\
\end{tabular} & \begin{tabular}{|l|l|}
-0.73 \\
\end{tabular} & \begin{tabular}{|c|}
-1.50 \\
\end{tabular} & 2.34 & 0.65 & \begin{tabular}{l|l|}
-0.05 \\
\end{tabular} & \begin{tabular}{l|l|}
-0.06 \\
\end{tabular} & 0.06 \\
\hline \begin{tabular}{|l} 
Strength Factor \\
\end{tabular} & -1.00 & -1.00 & -1.00 & -1.00 & 3.00 & 3.00 & -1.00 & -1.00 & 2.94 \\
\hline Weighted Value (12.5\%) & \begin{tabular}{|c|c|}
-0.13 \\
\end{tabular} & \begin{tabular}{|c|c|}
-0.13 \\
\end{tabular} & \begin{tabular}{|c|}
-0.13 \\
\end{tabular} & \begin{tabular}{l|l|}
-0.13 \\
\end{tabular} & \begin{tabular}{l|l|l}
0.38 \\
\end{tabular} & \begin{tabular}{l|l|}
0.38 \\
\end{tabular} & $\begin{array}{ll}-0.13 \\
\end{array}$ & $\begin{array}{ll}-0.13 \\
\end{array}$ & 0.37 \\
\hline \multicolumn{10}{|l|}{ Net Operating Revenues Ratio } \\
\hline$\Delta$ Unrestricted Net Assets & $-\$ 70,616$ & $-\$ 1,263,754$ & $-\$ 4,220,042$ & $-\$ 5,133,346$ & $-\$ 339,116$ & $-\$ 1,809,372$ & $-\$ 118,814$ & $\$ 390,080$ & $-\$ 104,115$ \\
\hline Total Unrestricted Revenue & $\$ 10,480,329$ & $\$ 11,468,063$ & $\$ 11,727,371$ & $\$ 12,185,626$ & $\$ 12,581,350$ & $\$ 12,378,016$ & $\$ 14,448,558$ & $\$ 14,850,898$ & $\$ 15,575,642$ \\
\hline Ratio & -0.01 & -0.11 & -0.36 & \begin{tabular}{|c|c|}
-0.42 \\
\end{tabular} & -0.03 & -0.15 & $\mid-0.01$ & 0.03 & -0.01 \\
\hline \begin{tabular}{|l|} 
Strength Factor \\
\end{tabular} & 0.83 & -1.00 & $\begin{array}{ll}-1.00 \\
\end{array}$ & -1.00 & 0.33 & $\begin{array}{ll}-1.00 \\
\end{array}$ & 0.79 & 2.31 & 0.83 \\
\hline Weighted Value (25\%) & 0.21 & -0.25 & -0.25 & $\begin{array}{ll}-0.25 \\
\end{array}$ & \begin{tabular}{l|l|}
0.08 \\
\end{tabular} & -0.25 & 0.20 & 0.58 & 0.21 \\
\hline \multicolumn{10}{|l|}{ Risk Factors } \\
\hline $\begin{array}{l}\text { Enrollment } \\
<1,000(2) \text { or }<2,500(1)\end{array}$ & 751 & 824 & 813 & 778 & 727 & 744 & 848 & 856 & 856 \\
\hline $\begin{array}{l}\text { Religious or Non-Degree Granting } \\
\text { yes }\end{array}$ & yes & yes & yes & yes & yes & yes & yes & yes & yes \\
\hline $\begin{array}{l}\text { Ratio of Full-time to Part-time Students } \\
<3.0\end{array}$ & 17.0 & 137.0 & 29.5 & 24.0 & 108.0 & 25.4 & 5.5 & 6.0 & no $\mathrm{P} / \mathrm{T}$ \\
\hline $\begin{array}{l}\text { Tuition Discounting } \\
>60 \%\end{array}$ & $19 \%$ & $19 \%$ & $19 \%$ & $23 \%$ & $21 \%$ & $24 \%$ & $22 \%$ & $23 \%$ & $23 \%$ \\
\hline $\begin{array}{l}\text { Tuition Reliance } \\
>85 \%\end{array}$ & $85 \%$ & $70 \%$ & $82 \%$ & $74 \%$ & $80 \%$ & $89 \%$ & $84 \%$ & $84 \%$ & $84 \%$ \\
\hline $\begin{array}{l}\text { Interest Expense } \\
>10 \%\end{array}$ & $3 \%$ & $3 \%$ & $8 \%$ & $11 \%$ & $12 \%$ & $13 \%$ & $12 \%$ & $10 \%$ & $10 \%$ \\
\hline $\begin{array}{l}\text { Net Revenue } \\
<0\end{array}$ & $-\$ 2,461,322$ & $-\$ 1,510,050$ & $-\$ 2,944,783$ & $-\$ 2,732,902$ & $-\$ 1,591,688$ & $-\$ 1,829,247$ & $\$ 271,612$ & $\$ 306,003$ & $-\$ 261,948$ \\
\hline $\begin{array}{l}\text { Endowment/Total Budget } \\
<3.0\end{array}$ & 27.93 & 659.70 & 639.91 & 710.96 & 21.29 & 18.64 & 15.30 & 12.90 & 0.00 \\
\hline Total Risk Factors & 5 & 4 & 4 & 5 & 5 & 6 & 4 & 4 & 4 \\
\hline Strength Factor & -1 & -1 & -1 & -1 & \begin{tabular}{l|l}
-1 \\
\end{tabular} & -1 & \begin{tabular}{l|}
-1 \\
\end{tabular} & -1 & -1 \\
\hline Weighted Value (25\%) & -0.25 & -0.25 & -0.25 & \begin{tabular}{ll|}
-0.25 \\
\end{tabular} & \begin{tabular}{|c|}
-0.25 \\
\end{tabular} & \begin{tabular}{|c|c|}
-0.25 \\
\end{tabular} & \begin{tabular}{ll|}
-0.25 \\
\end{tabular} & -0.25 & -0.25 \\
\hline
\end{tabular}


Saint Pauls College

\begin{tabular}{|c|c|c|c|c|c|c|c|c|c|}
\hline Year & 2005 & 2006 & 2007 & 2008 & 2009 & 2010 & 2011 & 2012 & 2013 \\
\hline MRA Composite Index & & & 0.7 & 0.8 & 0.8 & 1.4 & 1.8 & 1.9 & 0.8 \\
\hline FRCS & & & 0.9 & 1.0 & 0.4 & 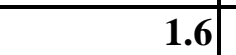 & 1.7 & 2.0 & \#N/A \\
\hline \multicolumn{10}{|l|}{ Index Components } \\
\hline Primary Reserve Ratio (25\%) & 0.00 & \begin{tabular}{|c|}
-0.17 \\
\end{tabular} & -0.17 & -0.13 & \begin{tabular}{ll|}
-0.02 \\
\end{tabular} & 0.21 & 0.26 & 0.36 & -0.25 \\
\hline Equity Ratio (12.5\%) & 0.30 & 0.31 & 0.32 & 0.33 & 0.30 & 0.36 & 0.38 & 0.38 & 0.38 \\
\hline Return on Net Assets Ratio (12.5\%) & \begin{tabular}{|c|}
-0.13 \\
\end{tabular} & \begin{tabular}{|c|}
-0.13 \\
\end{tabular} & 0.24 & 0.02 & -0.13 & 0.38 & 0.38 & 0.38 & -0.13 \\
\hline Net Operating Revenues Ratio (25\%) & \begin{tabular}{|c|}
-0.25 \\
\end{tabular} & 0.75 & 0.60 & 0.20 & 0.75 & \begin{tabular}{c|c|c|c|c|}
0.75 \\
\end{tabular} & 0.75 & 0.75 & -0.25 \\
\hline Risk Factors (25\%) & -0.25 & 0.00 & 0.00 & 0.25 & 0.00 & 0.25 & 0.25 & 0.00 & 0.00 \\
\hline MRA Index (Single Year) & \begin{tabular}{l|l}
-0.3 \\
\end{tabular} & 0.8 & 1.0 & \begin{tabular}{l|l}
0.7 \\
\end{tabular} & 0.9 & 2.0 & 2.0 & 1.9 & -0.3 \\
\hline \multicolumn{10}{|l|}{ Primary Reserve Ratio } \\
\hline Unrestricted Net Assets & $-\$ 1,374,769$ & $-\$ 350,066$ & $-\$ 72,050$ & $-\$ 154,176$ & $\$ 545,820$ & $\$ 1,895,418$ & $\$ 4,112,947$ & $\$ 4,982,178$ & $\$ 2,499,273$ \\
\hline Temporarily-restricted Net Assets & $\$ 6,394,514$ & $\$ 4,470,184$ & $\$ 4,372,551$ & $\$ 4,410,605$ & $\$ 2,229,885$ & $\$ 2,384,362$ & $\$ 2,536,965$ & $\$ 2,788,607$ & $\$ 2,685,519$ \\
\hline $\begin{array}{l}\text { Land, Building and Equipment, } \\
\text { net of depreciation }\end{array}$ & $\$ 11,798,701$ & $\$ 11,216,661$ & $\$ 11,055,491$ & $\$ 10,648,866$ & $\$ 10,792,890$ & $\$ 10,584,239$ & $\$ 12,203,895$ & $\$ 11,593,040$ & $\$ 11,038,792$ \\
\hline Long-term Debt & $\$ 6,759,726$ & $\$ 5,681,950$ & $\$ 5,390,281$ & $\$ 5,307,752$ & $\$ 7,832,386$ & $\$ 8,164,781$ & $\$ 7,769,081$ & $\$ 6,191,049$ & $\$ 3,147,240$ \\
\hline Total Expenses & $\$ 13,565,575$ & $\$ 20,479,303$ & $\$ 20,470,462$ & $\$ 21,187,751$ & $\$ 23,225,592$ & $\$ 21,797,725$ & $\$ 21,629,738$ & $\$ 16,226,155$ & $\$ 8,645,884$ \\
\hline$\overline{R a t i o}$ & 0.00 & -0.07 & -0.07 & -0.05 & -0.01 & 0.09 & 0.10 & 0.15 & -0.31 \\
\hline Strength Factor & \begin{tabular}{l|}
-0.01 \\
\end{tabular} & \begin{tabular}{l|l}
-0.69 \\
\end{tabular} & -0.67 & -0.51 & \begin{tabular}{ll|}
-0.08 \\
\end{tabular} & 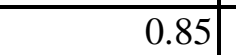 & 1.02 & 1.46 & -1.00 \\
\hline Weighted Value (25\%) & 0.00 & \begin{tabular}{l|l|l|l|l|}
-0.17 \\
\end{tabular} & -0.17 & -0.13 & \begin{tabular}{c|c|c|}
-0.02 \\
\end{tabular} & 0.21 & 0.26 & 0.36 & -0.25 \\
\hline \multicolumn{10}{|l|}{ Equity Ratio } \\
\hline Net Assets & $\$ 7,464,518$ & $\$ 7,183,341$ & $\$ 7,464,913$ & $\$ 7,485,965$ & $\$ 6,764,224$ & $\$ 9,309,713$ & $\$ 11,884,041$ & $\$ 12,936,782$ & $\$ 10,604,445$ \\
\hline Intangible Assets & $\$ 0$ & $\$ 0$ & $\$ 0$ & $\$ 0$ & $\$ 0$ & $\$ 0$ & $\$ 0$ & $\$ 0$ & $\$ 0$ \\
\hline Unsecured Related-party Receivables & $\$ 0$ & $\$ 0$ & $\$ 0$ & $\$ 0$ & $\$ 0$ & $\$ 450,000$ & $\$ 818,000$ & $\$ 218,000$ & $\$ 818,000$ \\
\hline Total Assets & $\$ 18,856,818$ & $\$ 17,518,517$ & $\$ 17,308,450$ & $\$ 17,079,036$ & $\$ 17,037,185$ & $\$ 18,747,755$ & $\$ 20,845,133$ & $\$ 19,961,453$ & $\$ 14,655,580$ \\
\hline - Intangible Assets & $\$ 0$ & $\$ 0$ & $\$ 0$ & $\$ 0$ & $\$ 0$ & $\$ 0$ & $\$ 0$ & $\$ 0$ & $\$ 0$ \\
\hline - Unsecured Related-party Receivables & $\$ 0$ & $\$ 0$ & $\$ 0$ & $\$ 0$ & $\$ 0$ & $\$ 450,000$ & $\$ 818,000$ & $\$ 218,000$ & $\$ 818,000$ \\
\hline Ratio & \begin{tabular}{l|l|}
0.40 & \\
\end{tabular} & 0.41 & 0.43 & 0.44 & \begin{tabular}{l|l|}
0.40 \\
\end{tabular} & 0.48 & 0.55 & 0.64 & 0.71 \\
\hline Strength Factor & 2.38 & 2.46 & 2.59 & $2.63 \mid$ & 2.38 & 2.91 & 3.00 & 3.00 & 3.00 \\
\hline Weighted Value (12.5\%) & \begin{tabular}{l|l|l}
0.30 & \\
\end{tabular} & 0.31 & 0.32 & 0.33 & \begin{tabular}{l|l|}
0.30 \\
\end{tabular} & 0.36 & 0.38 & 0.38 & 0.38 \\
\hline \multicolumn{10}{|l|}{ Return on Net Assets Ratio } \\
\hline$\Delta$ Net Assets & $-\$ 2,774,875$ & $-\$ 281,177$ & $\$ 281,572$ & $\$ 21,052$ & $-\$ 721,741$ & $\$ 2,545,489$ & $\$ 2,574,328$ & $\$ 1,052,741$ & $-\$ 2,332,337$ \\
\hline Total Net Assets (BOY) & $\$ 10,239,393$ & $\$ 7,464,518$ & $\$ 7,183,341$ & $\$ 7,464,913$ & $\$ 7,485,965$ & $\$ 6,764,224$ & $\$ 9,309,713$ & $\$ 11,884,041$ & $\$ 12,936,782$ \\
\hline Ratio & \begin{tabular}{|c|}
-0.27 \\
\end{tabular} & \begin{tabular}{|c|}
-0.04 \\
\end{tabular} & 0.04 & 0.00 & \begin{tabular}{l|l|l|l|}
-0.10 \\
\end{tabular} & 0.38 & 0.28 & 0.09 & -0.18 \\
\hline Strength Factor & \begin{tabular}{l|l}
-1.00 \\
\end{tabular} & \begin{tabular}{l|l}
-1.00 \\
\end{tabular} & 1.96 & 0.14 & \begin{tabular}{l|l}
-1.00 \\
\end{tabular} & 3.00 & 3.00 & 3.00 & -1.00 \\
\hline Weighted Value (12.5\%) & \begin{tabular}{|c|c|}
-0.13 \\
\end{tabular} & \begin{tabular}{|c|c|}
-0.13 \\
\end{tabular} & 0.24 & 0.02 & -0.13 & 0.38 & 0.38 & 0.38 & -0.13 \\
\hline \multicolumn{10}{|l|}{ Net Operating Revenues Ratio } \\
\hline$\Delta$ Unrestricted Net Assets & $-\$ 3,077,931$ & $\$ 1,024,703$ & $\$ 278,016$ & $-\$ 82,126$ & $\begin{array}{l}699,996 \\
\end{array}$ & \begin{tabular}{|l|}
$1,349,598$ \\
\end{tabular} & $\$ 2,217,529$ & $\$ 869,231$ & $-\$ 2,482,905$ \\
\hline Total Unrestricted Revenue & $\$ 7,933,231$ & $\$ 9,659,247$ & $\$ 9,986,956$ & $\$ 10,581,344$ & $\$ 10,485,985$ & $\$ 10,546,373$ & $\$ 9,383,078$ & $\$ 6,703,637$ & $\$ 2,220,855$ \\
\hline Ratio & 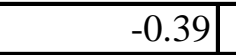 & 0.11 & 0.03 & -0.01 & \begin{tabular}{|c|}
0.07 \\
\end{tabular} & 0.13 & 0.24 & 0.13 & -1.12 \\
\hline Strength Factor & -1.00 & 3.00 & 2.39 & 0.81 & 3.00 & 3.00 & 3.00 & 3.00 & -1.00 \\
\hline Weighted Value (25\%) & -0.25 & 0.75 & 0.60 & 0.20 & 0.75 & 0.75 & 0.75 & 0.75 & -0.25 \\
\hline \multicolumn{10}{|l|}{ Risk Factors } \\
\hline $\begin{array}{l}\text { Enrollment } \\
<1,000(2) \text { or }<2,500(1)\end{array}$ & 598 & 701 & 665 & 679 & 631 & 573 & 560 & 405 & 405 \\
\hline $\begin{array}{l}\text { Religious or Non-Degree Granting } \\
\text { yes }\end{array}$ & no & no & no & no & no & no & no & no & no \\
\hline $\begin{array}{l}\text { Ratio of Full-time to Part-time Students } \\
<3.0\end{array}$ & 241.0 & 56.3 & no $P / T$ & 251.0 & 200.0 & no $P / T$ & no $P / T$ & no $P / T$ & no $P / T$ \\
\hline $\begin{array}{l}\text { Tuition Discounting } \\
>60 \%\end{array}$ & $11 \%$ & $19 \%$ & $16 \%$ & $22 \%$ & $18 \%$ & $23 \%$ & $15 \%$ & $10 \%$ & $10 \%$ \\
\hline $\begin{array}{l}\text { Tuition Reliance } \\
>85 \%\end{array}$ & $57 \%$ & $53 \%$ & $83 \%$ & $61 \%$ & $34 \%$ & $28 \%$ & $33 \%$ & $34 \%$ & $34 \%$ \\
\hline $\begin{array}{l}\text { Interest Expense } \\
>10 \%\end{array}$ & $2 \%$ & $2 \%$ & $3 \%$ & $2 \%$ & $1 \%$ & $1 \%$ & $1 \%$ & $1 \%$ & $2 \%$ \\
\hline $\begin{array}{l}\text { Net Revenue } \\
<0\end{array}$ & $-\$ 1,053,331$ & $-\$ 119,859$ & $-\$ 391,129$ & $\$ 90,675$ & $-\$ 726,573$ & $\$ 2,406,449$ & $\$ 2,219,618$ & $\$ 974,151$ & $-\$ 2,438,599$ \\
\hline $\begin{array}{l}\text { Endowment/Total Budget } \\
<3.0\end{array}$ & 2.86 & 4.27 & 4.27 & 5.44 & 5.42 & 4.99 & 4.12 & 2.79 & 0.00 \\
\hline \begin{tabular}{|l|} 
Total Risk Factors \\
\end{tabular} & \begin{tabular}{l|l}
4 \\
\end{tabular} & \begin{tabular}{l|l}
3 & \\
\end{tabular} & 3 & 2 & \begin{tabular}{l|l}
3 \\
\end{tabular} & $2 \mid$ & 2 & 3 & 3 \\
\hline Strength Factor & -1 & 0 & 0 & 1 & 0 & 1 & 1 & 0 & 0 \\
\hline Weighted Value (25\%) & -0.25 & \begin{tabular}{l|l|l|}
0.00 \\
\end{tabular} & 0.00 & 0.25 & 0.00 & 0.25 & 0.25 & 0.00 & 0.00 \\
\hline
\end{tabular}


St Andrews Presbyterian College

\begin{tabular}{|c|c|c|c|c|c|c|c|c|c|}
\hline Year & 2005 & 2006 & 2007 & 2008 & 2009 & 2010 & 2011 & 2012 & 2013 \\
\hline MRA Composite Index & & & 0.4 & 0.4 & -0.1 & -0.6 & -0.5 & 0.3 & 0.6 \\
\hline FRCS & & & -0.2 & -0.2 & -0.5 & \begin{tabular}{ll|}
-0.9 \\
\end{tabular} & -0.7 & \#N/A & \#N/A \\
\hline \multicolumn{10}{|l|}{ Index Components } \\
\hline Primary Reserve Ratio (25\%) & 0.01 & 0.75 & 0.62 & 0.59 & 0.11 & -0.25 & -0.25 & 0.32 & 0.17 \\
\hline Equity Ratio (12.5\%) & 0.24 & 0.13 & 0.14 & 0.14 & 0.00 & -0.07 & -0.11 & 0.18 & 0.13 \\
\hline Return on Net Assets Ratio (12.5\%) & -0.13 & -0.13 & 0.22 & 0.00 & -0.13 & -0.13 & 0.38 & -0.13 & 0.18 \\
\hline Net Operating Revenues Ratio (25\%) & -0.25 & 0.02 & -0.25 & -0.16 & -0.25 & -0.25 & 0.08 & 0.75 & 0.09 \\
\hline Risk Factors $(25 \%)$ & -0.25 & -0.25 & -0.25 & -0.25 & -0.25 & -0.25 & -0.25 & 0.00 & 0.00 \\
\hline MRA Index (Single Year) & \begin{tabular}{ll|}
-0.4 \\
\end{tabular} & 0.5 & 0.5 & 0.3 & -0.5 & \begin{tabular}{ll|}
-0.9 \\
\end{tabular} & -0.2 & 1.1 & 0.6 \\
\hline \multicolumn{10}{|l|}{ Primary Reserve Ratio } \\
\hline Unrestricted Net Assets & $-\$ 8,486,509$ & $-\$ 9,046,798$ & $-\$ 10,648,356$ & $-\$ 11,770,842$ & $-\$ 15,001,234$ & $-\$ 17,950,861$ & $-\$ 18,283,887$ & $-\$ 1,876,325$ & $-\$ 2,251,260$ \\
\hline Temporarily-restricted Net Assets & $\$ 2,762,285$ & $\$ 1,365,219$ & $\$ 1,449,434$ & $\$ 2,207,354$ & $\$ 1,189,624$ & $\$ 1,391,125$ & $\$ 589,943$ & $\$ 660,203$ & $\$ 806,970$ \\
\hline $\begin{array}{l}\text { Land, Building and Equipment, } \\
\text { net of depreciation }\end{array}$ & $\$ 6,974,328$ & $\$ 7,362,414$ & $\$ 8,285,680$ & $\$ 8,054,232$ & $\$ 8,118,563$ & $\$ 7,535,547$ & $\$ 7,218,075$ & $\$ 3,604,291$ & $\$ 4,072,091$ \\
\hline Long-term Debt & $\$ 12,758,499$ & $\$ 22,952,540$ & $\$ 23,175,722$ & $\$ 23,227,382$ & $\$ 22,951,548$ & $\$ 21,017,642$ & $\$ 20,711,104$ & $\$ 7,192,352$ & $\$ 6,849,282$ \\
\hline Total Expenses & $\$ 21,451,988$ & $\$ 21,601,254$ & $\$ 22,852,486$ & $\$ 23,661,076$ & $\$ 22,261,879$ & $\$ 21,227,584$ & $\$ 18,831,461$ & $\$ 18,575,901$ & $\$ 19,841,333$ \\
\hline Ratio & \begin{tabular}{l|l|}
0.00 \\
\end{tabular} & \begin{tabular}{l|l|}
0.37 \\
\end{tabular} & 0.25 & \begin{tabular}{l|l|}
0.24 \\
\end{tabular} & \begin{tabular}{l|l|}
0.05 \\
\end{tabular} & -0.14 & -0.22 & \begin{tabular}{l|l|}
0.13 \\
\end{tabular} & 0.07 \\
\hline Strength Factor & 0.03 & 3.00 & 2.49 & 2.37 & 0.46 & -1.00 & -1.00 & 1.28 & 0.67 \\
\hline Weighted Value (25\%) & 0.01 & 0.75 & 0.62 & 0.59 & 0.11 & -0.25 & -0.25 & 0.32 & 0.17 \\
\hline
\end{tabular}

\begin{tabular}{|c|c|c|c|c|c|c|c|c|c|}
\hline \multicolumn{10}{|l|}{ Equity Ratio } \\
\hline Net Assets & $\$ 7,087,597$ & $\$ 5,414,537$ & $\$ 5,605,301$ & $\$ 5,607,464$ & $\$ 133,675$ & $-\$ 2,091,946$ & $-\$ 3,299,677$ & $\$ 2,685,584$ & $\$ 2,762,222$ \\
\hline Intangible Assets & $\$ 0$ & $\$ 0$ & $\$ 0$ & $\$ 0$ & $\$ 0$ & $\$ 0$ & $\$ 0$ & $\$ 0$ & $\$ 0$ \\
\hline Unsecured Related-party Receivables & $\$ 0$ & $\$ 0$ & $\$ 0$ & $\$ 0$ & $\$ 0$ & $\$ 0$ & $\$ 0$ & $\$ 0$ & $\$ 746,802$ \\
\hline Total Assets & $\$ 21,773,615$ & $\$ 30,620,727$ & $\$ 30,984,800$ & $\$ 30,516,154$ & $\$ 26,296,363$ & $\$ 22,566,770$ & $\$ 21,786,413$ & $\$ 11,412,739$ & $\$ 12,332,239$ \\
\hline - Intangible Assets & $\$ 0$ & $\$ 0$ & $\$ 0$ & $\$ 0$ & $\$ 0$ & $\$ 0$ & $\$ 0$ & $\$ 0$ & $\$ 0$ \\
\hline \begin{tabular}{|l} 
- Unsecured Related-party Receivables \\
\end{tabular} & $\$ 0$ & $\$ 0$ & $\$ 0 \mid$ & $\$ 0$ & $\$ 0$ & $\$ 0$ & $\$ 0$ & $\$ 0$ & $\$ 746,802$ \\
\hline Ratio & 0.33 & 0.18 & \begin{tabular}{l|l}
0.18 \\
\end{tabular} & 0.18 & 0.01 & \begin{tabular}{l|l|}
-0.09 \\
\end{tabular} & \begin{tabular}{l|l|}
-0.15 \\
\end{tabular} & 0.24 & 0.17 \\
\hline Strength Factor & 1.95 & 1.06 & 1.09 & 1.10 & 0.03 & -0.56 & -0.91 & 1.41 & 1.04 \\
\hline Weighted Value (12.5\%) & 0.24 & 0.13 & 0.14 & 0.14 & 0.00 & -0.07 & -0.11 & 0.18 & 0.13 \\
\hline \multicolumn{10}{|l|}{ Return on Net Assets Ratio } \\
\hline$\Delta$ Net Assets & $-\$ 4,104,030$ & $-\$ 1,673,060$ & $\$ 190,764$ & $\$ 2,163$ & $-\$ 5,473,789$ & $-\$ 2,225,621$ & $-\$ 1,207,731$ & $\$ 5,985,261$ & $\$ 76,638$ \\
\hline Total Net Assets (BOY) & $\$ 11,191,627$ & $\$ 7,087,597$ & $\$ 5,414,537$ & $\$ 5,605,301$ & $\$ 5,607,464$ & $\$ 133,675$ & $-\$ 2,091,946$ & $-\$ 3,299,677$ & $\$ 2,685,584$ \\
\hline Ratio & -0.37 & -0.24 & 0.04 & 0.00 & -0.98 & -16.65 & 0.58 & -1.81 & 0.03 \\
\hline Strength Factor & -1.00 & -1.00 & 1.76 & 0.02 & -1.00 & -1.00 & 3.00 & -1.00 & 1.43 \\
\hline Weighted Value (12.5\%) & -0.13 & -0.13 & 0.22 & 0.00 & -0.13 & -0.13 & $\begin{array}{ll}0.38 \\
\end{array}$ & -0.13 & 0.18 \\
\hline \multicolumn{10}{|l|}{\begin{tabular}{|l|} 
Net Operating Revenues Ratio \\
\end{tabular}} \\
\hline$\Delta$ Unrestricted Net Assets & $-\$ 3,450,890$ & $-\$ 560,289$ & $-\$ 1,601,558$ & $-\$ 1,122,486$ & $-\$ 3,230,392$ & $-\$ 2,949,627$ & $-\$ 333,026$ & $\$ 16,407,562$ & $-\$ 374,935$ \\
\hline Total Unrestricted Revenue & $\$ 13,661,822$ & $\$ 15,092,436$ & $\$ 16,934,883$ & $\$ 17,178,585$ & $\$ 15,794,643$ & $\$ 15,299,923$ & $\$ 12,136,177$ & $\$ 12,705,025$ & $\$ 14,945,575$ \\
\hline Ratio & -0.25 & -0.04 & \begin{tabular}{l|l|}
-0.09 \\
\end{tabular} & -0.07 & -0.20 & \begin{tabular}{|l|}
-0.19 \\
\end{tabular} & \begin{tabular}{l|l|}
-0.03 \\
\end{tabular} & 1.29 & -0.03 \\
\hline Strength Factor & -1.00 & 0.07 & -1.00 & -0.63 & -1.00 & -1.00 & 0.31 & 3.00 & 0.37 \\
\hline Weighted Value (25\%) & -0.25 & 0.02 & $\begin{array}{ll}-0.25 \\
\end{array}$ & -0.16 & -0.25 & -0.25 & 0.08 & 0.75 & 0.09 \\
\hline \multicolumn{10}{|l|}{ Risk Factors } \\
\hline $\begin{array}{l}\text { Enrollment } \\
<1,000(2) \text { or }<2,500(1)\end{array}$ & 700 & 734 & 765 & 721 & 600 & 575 & 426 & 426 & 426 \\
\hline $\begin{array}{l}\text { Religious or Non-Degree Granting } \\
\text { yes }\end{array}$ & yes & yes & yes & yes & yes & yes & yes & yes & yes \\
\hline $\begin{array}{l}\text { Ratio of Full-time to Part-time Students } \\
<3.0\end{array}$ & 39.6 & 190.0 & no $P / T$ & 215.0 & no $\mathrm{P} / \mathrm{T}$ & no $\mathrm{P} / \mathrm{T}$ & no $P / T$ & no $\mathrm{P} / \mathrm{T}$ & no $\mathrm{P} / \mathrm{T}$ \\
\hline $\begin{array}{l}\text { Tuition Discounting } \\
>60 \%\end{array}$ & $51 \%$ & $41 \%$ & $43 \%$ & $45 \%$ & $42 \%$ & $43 \%$ & $47 \%$ & $47 \%$ & $47 \%$ \\
\hline $\begin{array}{l}\text { Tuition Reliance } \\
>85 \%\end{array}$ & $62 \%$ & $57 \%$ & $59 \%$ & $50 \%$ & $68 \%$ & $67 \%$ & $49 \%$ & $49 \%$ & $49 \%$ \\
\hline $\begin{array}{l}\text { Interest Expense } \\
>10 \%\end{array}$ & $3 \%$ & $2 \%$ & $3 \%$ & $2 \%$ & $3 \%$ & $6 \%$ & $7 \%$ & $2 \%$ & $1 \%$ \\
\hline $\begin{array}{l}\text { Net Revenue } \\
<0\end{array}$ & $-\$ 4,104,030$ & $-\$ 1,673,060$ & $\$ 190,765$ & $\$ 2,163$ & $-\$ 4,369,264$ & $-\$ 2,225,624$ & $-\$ 1,207,731$ & $\$ 5,475,864$ & $\$ 76,638$ \\
\hline $\begin{array}{l}\text { Endowment/Total Budget } \\
<3.0\end{array}$ & 2.05 & 1.50 & 1.53 & 1.69 & 1.93 & 1.79 & 1.55 & 0.00 & 0.00 \\
\hline Total Risk Factors & 5 & 5 & 4 & 4 & 5 & 5 & 5 & 3 & 3 \\
\hline Strength Factor & -1 & -1 & 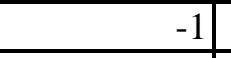 & -1 & -1 & -1 & -1 & 0 & 0 \\
\hline Weighted Value (25\%) & -0.25 & -0.25 & -0.25 & -0.25 & -0.25 & -0.25 & -0.25 & 0.00 & 0.00 \\
\hline
\end{tabular}




\section{Sterling College}

\begin{tabular}{|c|c|c|c|c|c|c|c|c|c|}
\hline Year & 2005 & 2006 & 2007 & 2008 & 2009 & 2010 & 2011 & 2012 & 2013 \\
\hline MRA Composite Index & & & 1.1 & 0.5 & -0.1 & 0.2 & 0.7 & 0.2 & 0.6 \\
\hline FRCS & & & 1.9 & 0.6 & 0.6 & 1.3 & 1.4 & \#N/A & 1.4 \\
\hline \multicolumn{10}{|l|}{ Index Components } \\
\hline Primary Reserve Ratio (25\%) & 0.13 & -0.14 & 0.27 & -0.11 & -0.25 & -0.25 & -0.25 & -0.25 & 0.27 \\
\hline Equity Ratio (12.5\%) & 0.38 & 0.38 & 0.38 & 0.38 & 0.38 & 0.38 & 0.38 & 0.38 & 0.38 \\
\hline Return on Net Assets Ratio (12.5\%) & -0.13 & 0.38 & 0.38 & -0.13 & -0.13 & 0.38 & 0.38 & -0.13 & 0.38 \\
\hline Net Operating Revenues Ratio (25\%) & -0.25 & 0.75 & 0.75 & -0.25 & -0.25 & 0.57 & 0.72 & -0.25 & 0.35 \\
\hline Risk Factors (25\%) & -0.25 & -0.25 & -0.25 & -0.25 & -0.25 & -0.25 & -0.25 & -0.25 & -0.25 \\
\hline MRA Index (Single Year) & -0.1 & 1.1 & 1.5 & -0.4 & -0.5 & 0.8 & 1.0 & -0.5 & 1.1 \\
\hline \multicolumn{10}{|l|}{ Primary Reserve Ratio } \\
\hline Unrestricted Net Assets & $\$ 4,632,914$ & $\$ 5,023,374$ & $\$ 5,925,182$ & $\$ 1,867,211$ & $-\$ 776,138$ & $-\$ 392,978$ & $\$ 190,983$ & $-\$ 1,144,580$ & $-\$ 1,018,520$ \\
\hline Temporarily-restricted Net Assets & $\$ 401,350$ & $\$ 875,024$ & $\$ 623,255$ & $\$ 416,238$ & $\$ 255,313$ & $\$ 297,143$ & $\$ 744,077$ & $\$ 715,911$ & $\$ 5,208,284$ \\
\hline $\begin{array}{l}\text { Land, Building and Equipment, } \\
\text { net of depreciation }\end{array}$ & $\$ 12,182,550$ & $\$ 11,692,058$ & $\$ 11,879,272$ & $\$ 9,922,962$ & $\$ 11,655,884$ & $\$ 11,143,488$ & $\$ 10,725,270$ & $\$ 10,170,238$ & $\$ 10,442,366$ \\
\hline Long-term Debt & $\$ 7,816,647$ & $\$ 5,059,353$ & $\$ 6,972,044$ & $\$ 6,953,946$ & $\$ 8,464,242$ & $\$ 7,602,979$ & $\$ 7,178,268$ & $\$ 7,045,666$ & $\$ 8,281,053$ \\
\hline Total Expenses & $\$ 12,712,124$ & $\$ 13,341,143$ & $\$ 15,409,423$ & $\$ 15,778,551$ & $\$ 16,777,407$ & $\$ 17,387,865$ & $\$ 18,086,176$ & $\$ 18,863,191$ & $\$ 18,603,867$ \\
\hline Ratio & 0.05 & -0.06 & 0.11 & -0.04 & -0.22 & -0.21 & -0.14 & -0.19 & 0.11 \\
\hline Strength Factor & 0.53 & -0.55 & 1.07 & -0.43 & -1.00 & -1.00 & -1.00 & -1.00 & 1.09 \\
\hline Weighted Value (25\%) & 0.13 & -0.14 & 0.27 & -0.11 & -0.25 & -0.25 & -0.25 & -0.25 & 0.27 \\
\hline \multicolumn{10}{|l|}{ Equity Ratio } \\
\hline Net Assets & $\$ 11,875,124$ & $\$ 15,763,476$ & $\$ 18,115,319$ & $\$ 14,006,064$ & $\$ 11,200,803$ & $\$ 12,214,802$ & $\$ 14,267,347$ & $\$ 13,068,914$ & $\$ 16,540,034$ \\
\hline Intangible Assets & $\$ 0$ & $\$ 0$ & $\$ 0$ & $\$ 0$ & $\$ 0$ & $\$ 0$ & $\$ 0$ & $\$ 0$ & $\$ 0$ \\
\hline Unsecured Related-party Receivables & $\$ 0$ & $\$ 0$ & $\$ 0$ & $\$ 0$ & $\$ 0$ & $\$ 0$ & $\$ 0$ & $\$ 0$ & $\$ 0$ \\
\hline Total Assets & $\$ 21,184,696$ & $\$ 21,686,587$ & $\$ 26,087,296$ & $\$ 22,398,274$ & $\$ 21,311,693$ & $\$ 21,337,537$ & $\$ 22,834,989$ & $\$ 22,114,009$ & $\$ 26,440,465$ \\
\hline - Intangible Assets & $\$ 0$ & $\$ 0$ & $\$ 0$ & $\$ 0$ & $\$ 0$ & $\$ 0$ & $\$ 0$ & $\$ 0$ & $\$ 0$ \\
\hline - Unsecured Related-party Receivables & $\$ 0$ & $\$ 0$ & $\$ 0$ & $\$ 0$ & $\$ 0$ & $\$ 0$ & $\$ 0$ & $\$ 0$ & $\$ 0$ \\
\hline Ratio & 0.56 & 0.73 & 0.69 & 0.63 & 0.53 & 0.57 & 0.62 & 0.59 & 0.63 \\
\hline Strength Factor & 3.00 & 3.00 & 3.00 & 3.00 & 3.00 & 3.00 & 3.00 & 3.00 & 3.00 \\
\hline Weighted Value $(12.5 \%)$ & 0.38 & 0.38 & 0.38 & 0.38 & 0.38 & 0.38 & 0.38 & 0.38 & 0.38 \\
\hline \multicolumn{10}{|l|}{ Return on Net Assets Ratio } \\
\hline$\Delta$ Net Assets & $-\$ 432,775$ & $\$ 3,888,352$ & $\$ 2,351,843$ & $-\$ 4,109,255$ & $-\$ 2,805,261$ & $\$ 1,013,999$ & $\$ 2,052,545$ & $-\$ 1,198,433$ & $\$ 3,471,120$ \\
\hline Total Net Assets (BOY) & $\$ 12,307,899$ & $\$ 11,875,124$ & $\$ 15,763,476$ & $\$ 18,115,319$ & $\$ 14,006,064$ & $\$ 11,200,803$ & $\$ 12,214,802$ & $\$ 14,267,347$ & $\$ 13,068,914$ \\
\hline Ratio & -0.04 & 0.33 & 0.15 & -0.23 & -0.20 & 0.09 & 0.17 & -0.08 & 0.27 \\
\hline Strength Factor & -1.00 & 3.00 & 3.00 & -1.00 & -1.00 & 3.00 & 3.00 & -1.00 & 3.00 \\
\hline Weighted Value (12.5\%) & -0.13 & 0.38 & 0.38 & -0.13 & -0.13 & 0.38 & 0.38 & -0.13 & 0.38 \\
\hline \multicolumn{10}{|l|}{ Net Operating Revenues Ratio } \\
\hline$\Delta$ Unrestricted Net Assets & $-\$ 1,390,029$ & $\$ 390,460$ & $\$ 901,808$ & $-\$ 4,057,971$ & $-\$ 2,643,349$ & $\$ 383,160$ & $\$ 583,961$ & $-\$ 1,335,563$ & $\$ 126,060$ \\
\hline Total Unrestricted Revenue & $\$ 8,171,618$ & $\$ 8,473,613$ & $\$ 10,500,012$ & $\$ 11,787,114$ & $\$ 12,605,413$ & $\$ 14,910,381$ & $\$ 15,558,241$ & $\$ 15,428,981$ & $\$ 15,488,776$ \\
\hline Ratio & -0.17 & 0.05 & 0.09 & -0.34 & -0.21 & 0.03 & 0.04 & \begin{tabular}{ll|}
-0.09 \\
\end{tabular} & 0.01 \\
\hline Strength Factor & -1.00 & 3.00 & 3.00 & -1.00 & -1.00 & 2.28 & 2.88 & -1.00 & 1.41 \\
\hline Weighted Value $(25 \%)$ & -0.25 & 0.75 & 0.75 & -0.25 & -0.25 & 0.57 & 0.72 & -0.25 & 0.35 \\
\hline \multicolumn{10}{|l|}{ Risk Factors } \\
\hline $\begin{array}{l}\text { Enrollment } \\
<1,000(2) \text { or }<2,500(1)\end{array}$ & 457 & 466 & 564 & 571 & 603 & 649 & 675 & 627 & 627 \\
\hline $\begin{array}{l}\text { Religious or Non-Degree Granting } \\
\text { yes }\end{array}$ & yes & yes & yes & yes & yes & yes & yes & yes & yes \\
\hline $\begin{array}{l}\text { Ratio of Full-time to Part-time Students } \\
<3.0\end{array}$ & no $P / T$ & no $P / T$ & 39.4 & 164.0 & no $P / T$ & 186.0 & 149.0 & no $P / T$ & no $\mathrm{P} / \mathrm{T}$ \\
\hline $\begin{array}{l}\text { Tuition Discounting } \\
>60 \%\end{array}$ & $56 \%$ & $52 \%$ & $51 \%$ & $46 \%$ & $39 \%$ & $73 \%$ & $147 \%$ & $87 \%$ & $87 \%$ \\
\hline $\begin{array}{l}\text { Tuition Reliance } \\
>85 \%\end{array}$ & $48 \%$ & $37 \%$ & $42 \%$ & $56 \%$ & $66 \%$ & $45 \%$ & $45 \%$ & $31 \%$ & $31 \%$ \\
\hline $\begin{array}{l}\text { Interest Expense } \\
>10 \%\end{array}$ & $0 \%$ & $0 \%$ & $0 \%$ & $0 \%$ & $0 \%$ & $2 \%$ & $2 \%$ & $2 \%$ & $2 \%$ \\
\hline $\begin{array}{l}\text { Net Revenue } \\
<0\end{array}$ & $-\$ 432,775$ & $\$ 3,888,352$ & $\$ 2,351,843$ & $-\$ 339,468$ & $-\$ 2,202,080$ & $\$ 464,709$ & $\$ 1,255,751$ & $-\$ 1,262,130$ & $\$ 205,379$ \\
\hline $\begin{array}{l}\text { Endowment/Total Budget } \\
<3.0\end{array}$ & 2.00 & 2.17 & 1.96 & 2.28 & 2.75 & 2.56 & 2.27 & 2.20 & 0.00 \\
\hline Total Risk Factors & 5 & 4 & 4 & 5 & 5 & 5 & 5 & 6 & 4 \\
\hline Strength Factor & -1 & -1 & -1 & -1 & -1 & -1 & $-1 \mid$ & $-1 \mid$ & -1 \\
\hline Weighted Value (25\%) & -0.25 & -0.25 & -0.25 & -0.25 & -0.25 & -0.25 & -0.25 & -0.25 & -0.25 \\
\hline
\end{tabular}




\section{Stillman College}

\begin{tabular}{|c|c|c|c|c|c|c|c|c|c|}
\hline Year & 2005 & 2006 & 2007 & 2008 & 2009 & 2010 & \begin{tabular}{|l|l|}
2011 \\
\end{tabular} & 2012 & 2013 \\
\hline MRA Composite Index & & & 0.5 & 0.4 & 0.5 & 1.0 & 1.7 & 2.1 & 1.8 \\
\hline FRCS & & & 1.9 & 1.8 & \begin{tabular}{l|l|}
0.8 \\
\end{tabular} & 1.5 & 2.0 & 2.2 & 1.8 \\
\hline \multicolumn{10}{|l|}{ Index Components } \\
\hline Primary Reserve Ratio (25\%) & 0.75 & 0.75 & 0.75 & 0.75 & 0.70 & 0.62 & 0.70 & 0.74 & 0.66 \\
\hline Equity Ratio (12.5\%) & 0.35 & 0.33 & 0.27 & 0.26 & 0.22 & 0.23 & 0.24 & 0.25 & 0.22 \\
\hline Return on Net Assets Ratio (12.5\%) & -0.13 & -0.13 & -0.13 & -0.13 & -0.13 & 0.12 & 0.37 & 0.21 & 0.00 \\
\hline Net Operating Revenues Ratio (25\%) & -0.25 & -0.25 & -0.25 & -0.25 & -0.25 & 0.50 & 0.75 & 0.71 & 0.26 \\
\hline Risk Factors $(25 \%)$ & 0.00 & -0.25 & -0.25 & -0.25 & 0.00 & 0.00 & 0.25 & 0.25 & 0.25 \\
\hline MRA Index (Single Year) & 0.7 & 0.5 & 0.4 & 0.4 & 0.5 & 1.5 & 2.3 & 2.2 & 1.4 \\
\hline
\end{tabular}

\begin{tabular}{|c|c|c|c|c|c|c|c|c|c|}
\hline \multicolumn{10}{|l|}{ Primary Reserve Ratio } \\
\hline Unrestricted Net Assets & $\$ 16,002,125$ & $\$ 13,617,231$ & $\$ 10,533,909$ & $\$ 7,088,814$ & $\$ 1,857,433$ & $\$ 2,253,672$ & $\$ 3,455,938$ & $\$ 4,182,341$ & $\$ 4,190,151$ \\
\hline Temporarily-restricted Net Assets & $\$ 1,500,025$ & $\$ 1,018,767$ & $\$ 999,188$ & $\$ 5,902$ & $\$ 4,543$ & $\$ 0$ & $\$ 0$ & $\$ 0$ & $\$ 0$ \\
\hline $\begin{array}{l}\text { Land, Building and Equipment, } \\
\text { net of depreciation }\end{array}$ & $\$ 44,245,324$ & $\$ 43,376,148$ & $\$ 41,939,895$ & $\$ 40,609,781$ & $\$ 39,463,987$ & $\$ 39,593,822$ & $\$ 39,044,784$ & $\$ 38,856,337$ & $\$ 41,425,809$ \\
\hline Long-term Debt & $\$ 35,637,966$ & $\$ 36,944,276$ & $\$ 47,669,288$ & $\$ 44,513,626$ & $\$ 44,815,694$ & $\$ 43,800,816$ & $\$ 42,769,565$ & $\$ 41,862,023$ & $\$ 43,871,950$ \\
\hline Total Expenses & $\$ 25,438,401$ & $\$ 23,292,341$ & $\$ 22,399,423$ & $\$ 24,997,937$ & $\$ 25,910,263$ & $\$ 26,189,505$ & $\$ 25,677,358$ & $\$ 24,230,834$ & $\$ 25,087,485$ \\
\hline Ratio & 0.35 & 0.35 & 0.77 & 0.44 & 0.28 & 0.25 & 0.28 & 0.30 & 0.26 \\
\hline Strength Factor & 3.00 & 3.00 & 3.00 & 3.00 & 2.78 & 2.47 & 2.80 & 2.97 & 2.65 \\
\hline Weighted Value (25\%) & 0.75 & 0.75 & 0.75 & 0.75 & 0.70 & 0.62 & 0.70 & 0.74 & 0.66 \\
\hline
\end{tabular}

\begin{tabular}{|c|c|c|c|c|c|c|c|c|c|}
\hline \multicolumn{10}{|l|}{\begin{tabular}{|l|} 
Equity Ratio \\
\end{tabular}} \\
\hline Net Assets & $\$ 35,350,077$ & $\$ 32,483,925$ & $\$ 29,381,024$ & $\$ 24,942,643$ & $\$ 19,709,903$ & $\$ 20,101,599$ & $\$ 21,303,865$ & $\$ 22,030,268$ & $\$ 22,038,078$ \\
\hline Intangible Assets & $\$ 0$ & $\$ 0$ & $\$ 0$ & $\$ 0$ & $\$ 0$ & $\$ 0$ & $\$ 0$ & $\$ 0$ & $\$ 0$ \\
\hline Unsecured Related-party Receivables & $\$ 0$ & $\$ 0$ & $\$ 0$ & $\$ 0$ & $\$ 0$ & $\$ 0$ & $\$ 0$ & $\$ 0$ & $\$ 1,600,000$ \\
\hline Total Assets & $\$ 74,949,933$ & $\$ 73,518,757$ & $\$ 81,325,317$ & $\$ 73,037,667$ & $\$ 67,812,615$ & $\$ 66,916,812$ & $\$ 66,397,137$ & $\$ 67,134,397$ & $\$ 69,979,350$ \\
\hline - Intangible Assets & $\$ 0$ & $\$ 0$ & $\$ 0$ & $\$ 0$ & $\$ 0$ & $\$ 0$ & $\$ 0$ & $\$ 0$ & $\$ 0$ \\
\hline - Unsecured Related-party Receivables & $\$ 0$ & $\$ 0$ & $\$ 0$ & $\$ 0$ & $\$ 0$ & $\$ 0$ & $\$ 0$ & $\$ 0$ & $\$ 1,600,000$ \\
\hline Ratio & 0.47 & 0.44 & 0.36 & 0.34 & 0.29 & 0.30 & 0.32 & 0.33 & 0.30 \\
\hline Strength Factor & 2.83 & 2.65 & 2.17 & 2.05 & 1.74 & 1.80 & 1.93 & 1.97 & 1.79 \\
\hline Weighted Value (12.5\%) & 0.35 & 0.33 & 0.27 & 0.26 & 0.22 & 0.23 & 0.24 & 0.25 & 0.22 \\
\hline \multicolumn{10}{|l|}{ Return on Net Assets Ratio } \\
\hline$\Delta$ Net Assets & $-\$ 2,389,806$ & $-\$ 2,866,152$ & $-\$ 3,102,901$ & $-\$ 4,438,381$ & $-\$ 5,232,740$ & $\$ 391,696$ & $\$ 1,202,266$ & $\$ 726,403$ & $\$ 7,810$ \\
\hline Total Net Assets (BOY) & $\$ 37,739,883$ & $\$ 35,350,077$ & $\$ 32,483,925$ & $\$ 29,381,024$ & $\$ 24,942,643$ & $\$ 19,709,903$ & $\$ 20,101,599$ & $\$ 21,303,865$ & $\$ 22,030,268$ \\
\hline Ratio & -0.06 & 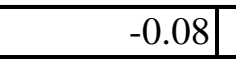 & -0.10 & -0.15 & -0.21 & 0.02 & 0.06 & 0.03 & 0.00 \\
\hline Strength Factor & -1.00 & -1.00 & -1.00 & -1.00 & -1.00 & 0.99 & 2.99 & 1.70 & 0.02 \\
\hline Weighted Value (12.5\%) & -0.13 & -0.13 & -0.13 & -0.13 & -0.13 & 0.12 & 0.37 & 0.21 & 0.00 \\
\hline \multicolumn{10}{|l|}{ Net Operating Revenues Ratio } \\
\hline$\Delta$ Unrestricted Net Assets & $-\$ 2,300,791$ & $-\$ 2,384,894$ & $-\$ 3,083,322$ & $-\$ 3,445,095$ & $-\$ 5,231,381$ & $\$ 396,239$ & $\$ 1,202,266$ & $\$ 726,403$ & $\$ 7,810$ \\
\hline Total Unrestricted Revenue & $\$ 14,245,332$ & $\$ 12,611,354$ & $\$ 12,708,606$ & $\$ 14,353,303$ & $\$ 15,138,660$ & $\$ 19,710,874$ & $\$ 19,598,880$ & $\$ 19,620,023$ & $\$ 18,045,717$ \\
\hline Ratio & -0.16 & \begin{tabular}{l|l|}
-0.19 \\
\end{tabular} & -0.24 & -0.24 & -0.35 & 0.02 & 0.06 & 0.04 & 0.00 \\
\hline Strength Factor & -1.00 & -1.00 & -1.00 & -1.00 & -1.00 & 2.01 & 3.00 & 2.85 & 1.02 \\
\hline Weighted Value $(25 \%)$ & -0.25 & -0.25 & -0.25 & -0.25 & -0.25 & 0.50 & 0.75 & 0.71 & 0.26 \\
\hline \multicolumn{10}{|l|}{ Risk Factors } \\
\hline $\begin{array}{l}\text { Enrollment } \\
<1,000(2) \text { or }<2,500(1)\end{array}$ & 1072 & 785 & 793 & 894 & 1036 & 1024 & 1032 & 1046 & 1046 \\
\hline $\begin{array}{l}\text { Religious or Non-Degree Granting } \\
\text { yes }\end{array}$ & no & no & no & no & no & no & no & no & no \\
\hline $\begin{array}{l}\text { Ratio of Full-time to Part-time Students } \\
<3.0\end{array}$ & 18.1 & 29.6 & 56.4 & 31.4 & 60.6 & 47.9 & 15.6 & 15.9 & no $\mathrm{P} / \mathrm{T}$ \\
\hline $\begin{array}{l}\text { Tuition Discounting } \\
>60 \%\end{array}$ & $12 \%$ & $26 \%$ & $25 \%$ & $30 \%$ & $29 \%$ & $27 \%$ & $19 \%$ & $27 \%$ & $27 \%$ \\
\hline $\begin{array}{l}\text { Tuition Reliance } \\
>85 \%\end{array}$ & $59 \%$ & $52 \%$ & $55 \%$ & $55 \%$ & $64 \%$ & $65 \%$ & $66 \%$ & $67 \%$ & $67 \%$ \\
\hline $\begin{array}{l}\text { Interest Expense } \\
>10 \%\end{array}$ & $0 \%$ & $0 \%$ & $0 \%$ & $0 \%$ & $0 \%$ & $0 \%$ & $0 \%$ & $0 \%$ & $0 \%$ \\
\hline $\begin{array}{l}\text { Net Revenue } \\
<0\end{array}$ & $-\$ 2,947,816$ & $-\$ 2,866,152$ & $-\$ 1,352,032$ & $-\$ 4,438,381$ & $-\$ 5,232,740$ & $-\$ 452,141$ & $\$ 378,115$ & $\$ 1,335,399$ & $-\$ 128,560$ \\
\hline $\begin{array}{l}\text { Endowment/Total Budget } \\
<3.0\end{array}$ & 1.04 & 1.00 & 0.71 & 1.26 & 1.49 & 1.70 & 1.66 & 1.29 & 0.00 \\
\hline Total Risk Factors & 3 & 4 & 4 & 4 & 3 & 3 & 2 & 2 & 2 \\
\hline Strength Factor & 0 & -1 & -1 & -1 & 0 & 0 & 1 & 1 & 1 \\
\hline Weighted Value $(25 \%)$ & 0.00 & -0.25 & -0.25 & -0.25 & 0.00 & 0.00 & 0.25 & 0.25 & 0.25 \\
\hline
\end{tabular}




\section{Tennessee Wesleyan College}

\begin{tabular}{|c|c|c|c|c|c|c|c|c|c|}
\hline Year & 2005 & 2006 & 2007 & 2008 & 2009 & 2010 & 2011 & 2012 & 2013 \\
\hline MRA Composite Index & & & 1.3 & 0.9 & 0.2 & -0.2 & 0.5 & 0.8 & 1.4 \\
\hline FRCS & & & 2.6 & 0.8 & 0.3 & 0.3 & 1.4 & 1.2 & 1.7 \\
\hline \multicolumn{10}{|l|}{ Index Components } \\
\hline Primary Reserve Ratio (25\%) & 0.41 & 0.35 & 0.61 & 0.75 & -0.20 & -0.07 & 0.14 & 0.24 & 0.24 \\
\hline Equity Ratio (12.5\%) & 0.38 & 0.38 & 0.36 & 0.32 & 0.27 & 0.26 & 0.30 & 0.30 & 0.33 \\
\hline Return on Net Assets Ratio (12.5\%) & 0.18 & 0.08 & 0.38 & -0.13 & -0.13 & -0.13 & 0.38 & 0.14 & 0.38 \\
\hline Net Operating Revenues Ratio (25\%) & 0.31 & 0.12 & 0.62 & -0.25 & -0.25 & -0.05 & 0.75 & 0.43 & 0.75 \\
\hline Risk Factors (25\%) & -0.25 & -0.25 & -0.25 & -0.25 & -0.25 & -0.25 & -0.25 & -0.25 & 0.00 \\
\hline MRA Index (Single Year) & 1.0 & 0.7 & 1.7 & 0.4 & -0.5 & -0.2 & 1.3 & 0.9 & 1.7 \\
\hline \multicolumn{10}{|l|}{ Primary Reserve Ratio } \\
\hline Unrestricted Net Assets & $\$ 3,911,080$ & $\$ 3,658,560$ & $\$ 4,040,459$ & $\$ 2,410,354$ & $\$ 525,406$ & $-\$ 474,454$ & $\$ 1,329,350$ & $\$ 1,655,145$ & $\$ 2,732,050$ \\
\hline Temporarily-restricted Net Assets & $\$ 1,153,182$ & $\$ 1,087,787$ & $\$ 1,573,892$ & $\$ 9,256,941$ & $\$ 511,178$ & $\$ 880,805$ & $\$ 1,085,009$ & $\$ 810,001$ & $\$ 652,373$ \\
\hline $\begin{array}{l}\text { Land, Building and Equipment, } \\
\text { net of depreciation }\end{array}$ & $\$ 7,087,098$ & $\$ 7,916,335$ & $\$ 15,239,160$ & $\$ 17,177,278$ & $\$ 17,423,768$ & $\$ 17,150,964$ & $\$ 16,645,536$ & $\$ 16,005,470$ & $\$ 15,847,589$ \\
\hline Long-term Debt & $\$ 3,974,476$ & $\$ 5,072,013$ & $\$ 13,356,634$ & $\$ 14,927,800$ & $\$ 15,008,900$ & $\$ 16,236,899$ & $\$ 15,668,341$ & $\$ 15,832,916$ & $\$ 14,811,058$ \\
\hline Total Expenses & $\$ 11,861,616$ & $\$ 13,422,045$ & $\$ 15,208,765$ & $\$ 17,547,538$ & $\$ 19,665,832$ & $\$ 22,663,410$ & $\$ 22,375,480$ & $\$ 23,128,153$ & $\$ 24,147,445$ \\
\hline Ratio & 0.16 & 0.14 & 0.25 & 0.54 & -0.08 & -0.03 & 0.06 & 0.10 & 0.09 \\
\hline Strength Factor & 1.65 & 1.42 & 2.45 & 3.00 & -0.78 & -0.29 & 0.58 & 0.96 & 0.95 \\
\hline Weighted Value (25\%) & 0.41 & 0.35 & 0.61 & 0.75 & -0.20 & -0.07 & 0.14 & 0.24 & 0.24 \\
\hline \multicolumn{10}{|l|}{ Equity Ratio } \\
\hline Net Assets & $\$ 13,399,387$ & $\$ 13,578,892$ & $\$ 14,871,292$ & $\$ 12,205,416$ & $\$ 9,947,669$ & $\$ 9,617,170$ & $\$ 11,572,345$ & $\$ 11,837,116$ & $\$ 12,798,541$ \\
\hline Intangible Assets & $\$ 0$ & $\$ 0$ & $\$ 0$ & $\$ 0$ & $\$ 157,474$ & $\$ 151,495$ & $\$ 145,517$ & $\$ 68,150$ & $\$ 65,354$ \\
\hline Unsecured Related-party Receivables & $\$ 0$ & $\$ 0$ & $\$ 0$ & $\$ 0$ & $\$ 0$ & $\$ 0$ & $\$ 0$ & $\$ 0$ & $\$ 0$ \\
\hline Total Assets & $\$ 17,707,191$ & $\$ 19,886,724$ & $\$ 30,754,941$ & $\$ 28,510,079$ & $\$ 26,878,860$ & $\$ 27,565,634$ & $\$ 28,726,557$ & $\$ 29,188,803$ & $\$ 29,139,698$ \\
\hline - Intangible Assets & $\$ 0$ & $\$ 0$ & $\$ 0$ & $\$ 0$ & $\$ 157,474$ & $\$ 151,495$ & $\$ 145,517$ & $\$ 68,150$ & $\$ 65,354$ \\
\hline - Unsecured Related-party Receivables & $\$ 0$ & $\$ 0$ & $\$ 0$ & $\$ 0$ & $\$ 0$ & $\$ 0$ & $\$ 0$ & $\$ 0$ & $\$ 0$ \\
\hline Ratio & 0.76 & 0.68 & 0.48 & 0.43 & 0.37 & 0.35 & 0.40 & 0.40 & 0.44 \\
\hline Strength Factor & 3.00 & 3.00 & 2.90 & 2.57 & 2.20 & 2.07 & 2.40 & 2.42 & 2.63 \\
\hline Weighted Value $(12.5 \%)$ & 0.38 & 0.38 & 0.36 & 0.32 & 0.27 & 0.26 & 0.30 & 0.30 & 0.33 \\
\hline \multicolumn{10}{|l|}{ Return on Net Assets Ratio } \\
\hline$\Delta$ Net Assets & $\$ 377,741$ & $\$ 179,505$ & $\$ 1,292,400$ & $-\$ 2,665,876$ & $-\$ 2,257,747$ & $-\$ 330,499$ & $\$ 1,955,175$ & $\$ 264,771$ & $\$ 961,425$ \\
\hline Total Net Assets (BOY) & $\$ 13,021,646$ & $\$ 13,399,387$ & $\$ 13,578,892$ & $\$ 14,871,292$ & $\$ 12,205,416$ & $\$ 9,947,669$ & $\$ 9,617,170$ & $\$ 11,572,345$ & $\$ 11,837,116$ \\
\hline Ratio & 0.03 & 0.01 & 0.10 & -0.18 & -0.18 & -0.03 & 0.20 & 0.02 & 0.08 \\
\hline Strength Factor & 1.45 & 0.67 & 3.00 & -1.00 & -1.00 & -1.00 & 3.00 & 1.14 & 3.00 \\
\hline Weighted Value (12.5\%) & 0.18 & 0.08 & 0.38 & -0.13 & -0.13 & -0.13 & 0.38 & 0.14 & 0.38 \\
\hline \multicolumn{10}{|l|}{ Net Operating Revenues Ratio } \\
\hline$\Delta$ Unrestricted Net Assets & $\$ 44,863$ & $-\$ 252,520$ & $\$ 381,899$ & $-\$ 1,630,105$ & $-\$ 1,884,948$ & $-\$ 999,860$ & $\$ 1,803,804$ & $\$ 325,795$ & $\$ 1,076,905$ \\
\hline Total Unrestricted Revenue & $\$ 10,167,615$ & $\$ 11,922,867$ & $\$ 12,909,995$ & $\$ 14,171,640$ & $\$ 17,728,266$ & $\$ 20,596,073$ & $\$ 22,028,618$ & $\$ 22,566,154$ & $\$ 23,352,125$ \\
\hline Ratio & 0.00 & -0.02 & 0.03 & -0.12 & -0.11 & -0.05 & 0.08 & 0.01 & 0.05 \\
\hline Strength Factor & 1.22 & 0.47 & 2.48 & -1.00 & -1.00 & -0.21 & 3.00 & 1.72 & 3.00 \\
\hline Weighted Value (25\%) & 0.31 & 0.12 & 0.62 & -0.25 & -0.25 & -0.05 & 0.75 & 0.43 & 0.75 \\
\hline \multicolumn{10}{|l|}{ Risk Factors } \\
\hline $\begin{array}{l}\text { Enrollment } \\
<1,000(2) \text { or }<2,500(1)\end{array}$ & 737 & 785 & 791 & 786 & 902 & 988 & 1025 & 1027 & 1027 \\
\hline $\begin{array}{l}\text { Religious or Non-Degree Granting } \\
\text { yes }\end{array}$ & yes & yes & yes & yes & yes & yes & yes & yes & yes \\
\hline $\begin{array}{l}\text { Ratio of Full-time to Part-time Students } \\
<3.0\end{array}$ & 54.3 & 83.5 & 160.0 & 77.6 & 87.0 & 82.0 & 77.1 & 103.0 & no $P / T$ \\
\hline $\begin{array}{l}\text { Tuition Discounting } \\
>60 \%\end{array}$ & $37 \%$ & $38 \%$ & $39 \%$ & $40 \%$ & $42 \%$ & $45 \%$ & $44 \%$ & $44 \%$ & $44 \%$ \\
\hline $\begin{array}{l}\text { Tuition Reliance } \\
>85 \%\end{array}$ & $78 \%$ & $84 \%$ & $75 \%$ & $81 \%$ & $91 \%$ & $86 \%$ & $90 \%$ & $88 \%$ & $88 \%$ \\
\hline $\begin{array}{l}\text { Interest Expense } \\
>10 \%\end{array}$ & $1 \%$ & $1 \%$ & $3 \%$ & $4 \%$ & $4 \%$ & $4 \%$ & $6 \%$ & $5 \%$ & $3 \%$ \\
\hline $\begin{array}{l}\text { Net Revenue } \\
<0\end{array}$ & $\$ 220,905$ & $\$ 328,435$ & $\$ 881,770$ & $-\$ 583,150$ & $-\$ 1,012,179$ & $-\$ 441,330$ & $\$ 998,783$ & $\$ 1,659,327$ & $\$ 400,880$ \\
\hline $\begin{array}{l}\text { Endowment/Total Budget } \\
<3.0\end{array}$ & 1.38 & 1.39 & 1.50 & 1.96 & 2.56 & 2.74 & 2.33 & 2.42 & 0.00 \\
\hline Total Risk Factors & 4 & 4 & 4 & 5 & 6 & 6 & 4 & 4 & 3 \\
\hline Strength Factor & -1 & -1 & -1 & -1 & -1 & -1 & -1 & -1 & 0 \\
\hline Weighted Value (25\%) & -0.25 & -0.25 & -0.25 & -0.25 & -0.25 & -0.25 & -0.25 & -0.25 & 0.00 \\
\hline
\end{tabular}


Vanguard University of Southern California

\begin{tabular}{|c|c|c|c|c|c|c|c|c|c|}
\hline Year & 2005 & 2006 & 2007 & 2008 & 2009 & 2010 & 2011 & 2012 & 2013 \\
\hline MRA Composite Index & & & 1.7 & 0.8 & 0.4 & 0.3 & 1.1 & 1.5 & 1.7 \\
\hline FRCS & & & 1.4 & \begin{tabular}{ll|}
-0.1 \\
\end{tabular} & 0.5 & 0.4 & 1.4 & 1.8 & 1.9 \\
\hline \multicolumn{10}{|l|}{\begin{tabular}{|l|} 
Index Components \\
\end{tabular}} \\
\hline Primary Reserve Ratio (25\%) & 0.64 & 0.67 & 0.69 & 0.53 & 0.33 & 0.36 & 0.55 & 0.49 & 0.39 \\
\hline Equity Ratio (12.5\%) & 0.11 & 0.10 & 0.10 & 0.01 & -0.02 & 0.01 & 0.07 & 0.11 & 0.19 \\
\hline Return on Net Assets Ratio (12.5\%) & 0.32 & -0.06 & 0.38 & -0.13 & -0.13 & -0.13 & 0.38 & 0.38 & 0.38 \\
\hline Net Operating Revenues Ratio (25\%) & 0.66 & 0.42 & 0.41 & -0.25 & 0.02 & 0.30 & 0.75 & 0.74 & 0.75 \\
\hline Risk Factors (25\%) & 0.25 & 0.25 & 0.25 & -0.25 & 0.00 & 0.00 & 0.00 & 0.00 & 0.00 \\
\hline MRA Index (Single Year) & 2.0 & 1.4 & 1.8 & $\begin{array}{ll}-0.1 \\
\end{array}$ & 0.2 & 0.5 & 1.7 & 1.7 & 1.7 \\
\hline \multicolumn{10}{|l|}{ Primary Reserve Ratio } \\
\hline Unrestricted Net Assets & $\$ 4,082,986$ & $\$ 4,664,530$ & $\$ 5,232,679$ & $-\$ 2,322,879$ & $-\$ 4,317,846$ & $-\$ 4,135,132$ & $-\$ 120,555$ & $\$ 2,010,465$ & $\$ 5,225,787$ \\
\hline Temporarily-restricted Net Assets & $\$ 743,922$ & $\$ 240,602$ & $\$ 189,463$ & $\$ 1,657,511$ & $\$ 2,990,573$ & $\$ 4,573,911$ & $\$ 3,797,153$ & $\$ 4,256,232$ & $\$ 4,836,984$ \\
\hline $\begin{array}{l}\text { Land, Building and Equipment, } \\
\text { net of depreciation }\end{array}$ & $\$ 27,941,334$ & $\$ 27,438,777$ & $\$ 28,567,225$ & $\$ 27,827,592$ & $\$ 28,035,173$ & $\$ 26,357,125$ & $\$ 25,343,072$ & $\$ 25,833,811$ & $\$ 26,714,282$ \\
\hline Long-term Debt & $\$ 34,413,447$ & $\$ 35,479,395$ & $\$ 37,759,229$ & $\$ 40,569,194$ & $\$ 36,579,874$ & $\$ 33,444,240$ & $\$ 32,902,539$ & $\$ 30,329,143$ & $\$ 25,762,070$ \\
\hline Total Expenses & $\$ 43,943,798$ & $\$ 48,088,537$ & $\$ 52,683,402$ & $\$ 57,034,228$ & $\$ 55,219,266$ & $\$ 51,609,475$ & $\$ 51,109,875$ & $\$ 54,872,646$ & $\$ 58,326,652$ \\
\hline Ratio & 0.26 & 0.27 & 0.28 & 0.21 & 0.13 & 0.15 & 0.22 & \begin{tabular}{l|l}
0.20 \\
\end{tabular} & 0.16 \\
\hline Strength Factor & 2.57 & 2.69 & 2.77 & 2.12 & 1.31 & 1.46 & 2.20 & 1.96 & 1.56 \\
\hline Weighted Value $(25 \%)$ & 0.64 & 0.67 & 0.69 & 0.53 & 0.33 & 0.36 & \begin{tabular}{l|l|l}
0.55 \\
\end{tabular} & \begin{tabular}{l|l}
0.49 \\
\end{tabular} & 0.39 \\
\hline \multicolumn{10}{|l|}{ Equity Ratio } \\
\hline Net Assets & $\$ 6,132,949$ & $\$ 6,077,667$ & $\$ 6,743,909$ & $\$ 334,632$ & $-\$ 1,327,273$ & $\$ 438,779$ & $\$ 3,676,702$ & $\$ 6,280,144$ & $\$ 10,113,353$ \\
\hline Intangible Assets & $\$ 0$ & $\$ 0$ & $\$ 0$ & $\$ 0$ & $\$ 0$ & $\$ 0$ & $\$ 0$ & $\$ 0$ & $\$ 0$ \\
\hline Unsecured Related-party Receivables & $\$ 0$ & $\$ 0$ & $\$ 0$ & $\$ 0$ & $\$ 0$ & $\$ 0$ & $\$ 0$ & $\$ 0$ & $\$ 0$ \\
\hline Total Assets & $\$ 43,114,986$ & $\$ 43,680,735$ & $\$ 48,875,052$ & $\$ 46,020,046$ & $\$ 40,733,821$ & $\$ 38,248,173$ & $\$ 39,670,172$ & $\$ 40,977,858$ & $\$ 40,488,459$ \\
\hline - Intangible Assets & $\$ 0$ & $\$ 0$ & $\$ 0$ & $\$ 0$ & $\$ 0$ & $\$ 0$ & $\$ 0$ & $\$ 0$ & $\$ 0$ \\
\hline - Unsecured Related-party Receivables & $\$ 0$ & $\$ 0$ & $\$ 0$ & $\$ 0$ & $\$ 0$ & $\$ 0$ & $\$ 0$ & $\$ 0$ & $\$ 0$ \\
\hline Ratio & 0.14 & 0.14 & 0.14 & 0.01 & -0.03 & 0.01 & 0.09 & 0.15 & 0.25 \\
\hline Strength Factor & 0.85 & 0.83 & 0.83 & 0.04 & -0.20 & 0.07 & 0.56 & 0.92 & 1.50 \\
\hline Weighted Value (12.5\%) & 0.11 & 0.10 & 0.10 & 0.01 & \begin{tabular}{ll|}
-0.02 \\
\end{tabular} & 0.01 & \begin{tabular}{l|l|l|l|l}
0.07 \\
\end{tabular} & \begin{tabular}{l|l}
0.11 \\
\end{tabular} & 0.19 \\
\hline \multicolumn{10}{|l|}{\begin{tabular}{|l|} 
Return on Net Assets Ratio \\
\end{tabular}} \\
\hline$\Delta$ Net Assets & $\$ 298,072$ & $-\$ 55,282$ & $\$ 666,242$ & $-\$ 6,409,277$ & $-\$ 1,661,905$ & $\$ 1,766,052$ & $\$ 3,237,923$ & $\$ 2,603,442$ & $\$ 3,833,209$ \\
\hline Total Net Assets (BOY) & $\$ 5,834,877$ & $\$ 6,132,949$ & $\$ 6,077,667$ & $\$ 6,743,909$ & $\$ 334,632$ & $-\$ 1,327,273$ & $\begin{array}{l}\$ 438,779 \\
\end{array}$ & $\$ 3,676,702$ & $\$ 6,280,144$ \\
\hline Ratio & 0.05 & -0.01 & 0.11 & -0.95 & -4.97 & -1.33 & 7.38 & 0.71 & 0.61 \\
\hline Strength Factor & 2.55 & -0.45 & 3.00 & -1.00 & -1.00 & -1.00 & 3.00 & 3.00 & 3.00 \\
\hline Weighted Value (12.5\%) & 0.32 & -0.06 & 0.38 & -0.13 & \begin{tabular}{|c|}
-0.13 \\
\end{tabular} & -0.13 & \begin{tabular}{l|l}
0.38 \\
\end{tabular} & \begin{tabular}{l|l|l}
0.38 \\
\end{tabular} & 0.38 \\
\hline \multicolumn{10}{|l|}{\begin{tabular}{|l|} 
Net Operating Revenues Ratio \\
\end{tabular}} \\
\hline$\Delta$ Unrestricted Net Assets & $\$ 1,265,032$ & $\$ 581,544$ & $\$ 568,149$ & $-\$ 7,555,558$ & $-\$ 1,994,967$ & $\$ 182,714$ & $\$ 4,014,577$ & $\$ 2,131,020$ & $\$ 3,215,322$ \\
\hline Total Unrestricted Revenue & $\$ 38,137,432$ & $\$ 42,176,831$ & $\$ 45,587,897$ & $\$ 46,632,299$ & $\$ 53,831,016$ & $\$ 49,965,583$ & $\$ 51,650,668$ & $\$ 54,637,175$ & $\$ 59,592,017$ \\
\hline Ratio & 0.03 & 0.01 & 0.01 & -0.16 & -0.04 & 0.00 & 0.08 & 0.04 & 0.05 \\
\hline Strength Factor & 2.66 & 1.69 & 1.62 & -1.00 & 0.07 & 1.18 & 3.00 & 2.95 & 3.00 \\
\hline Weighted Value (25\%) & 0.66 & 0.42 & 0.41 & -0.25 & 0.02 & 0.30 & 0.75 & 0.74 & 0.75 \\
\hline \multicolumn{10}{|l|}{ Risk Factors } \\
\hline $\begin{array}{l}\text { Enrollment } \\
<1,000(2) \text { or }<2,500(1)\end{array}$ & 1811 & 1863 & 1867 & 1883 & 1802 & 1608 & 1693 & 1803 & 1803 \\
\hline $\begin{array}{l}\text { Religious or Non-Degree Granting } \\
\text { yes }\end{array}$ & yes & yes & yes & yes & yes & yes & yes & yes & yes \\
\hline $\begin{array}{l}\text { Ratio of Full-time to Part-time Students } \\
<3.0\end{array}$ & 68.8 & 79.6 & 78.2 & 369.0 & 99.7 & 87.0 & 41.8 & 79.4 & no $\mathrm{P} / \mathrm{T}$ \\
\hline $\begin{array}{l}\text { Tuition Discounting } \\
>60 \%\end{array}$ & $39 \%$ & $39 \%$ & $39 \%$ & $35 \%$ & $29 \%$ & $32 \%$ & $35 \%$ & $38 \%$ & $38 \%$ \\
\hline $\begin{array}{l}\text { Tuition Reliance } \\
>85 \%\end{array}$ & $83 \%$ & $83 \%$ & $79 \%$ & $89 \%$ & $89 \%$ & $90 \%$ & $91 \%$ & $91 \%$ & $91 \%$ \\
\hline $\begin{array}{l}\text { Interest Expense } \\
>10 \%\end{array}$ & $5 \%$ & $4 \%$ & $4 \%$ & $4 \%$ & $4 \%$ & $4 \%$ & $4 \%$ & $3 \%$ & $3 \%$ \\
\hline $\begin{array}{l}\text { Net Revenue } \\
<0\end{array}$ & $\$ 298,072$ & $\$ 69,718$ & $\$ 666,242$ & $-\$ 6,926,955$ & $\$ 3,100,619$ & $\$ 1,733,788$ & $\$ 3,237,923$ & $\$ 2,571,720$ & $\$ 3,746,436$ \\
\hline $\begin{array}{l}\text { Endowment/Total Budget } \\
<3.0\end{array}$ & 11.21 & 12.41 & 7.40 & 15.62 & 11.13 & 11.41 & 12.68 & $14.77 \mid$ & 0.00 \\
\hline Total Risk Factors & 2 & 2 & 2 & 4 & 3 & 3 & $3 \mid$ & 3 & 3 \\
\hline Strength Factor & 1 & 1 & 1 & -1 & 0 & 0 & 0 & 0 & 0 \\
\hline Weighted Value (25\%) & 0.25 & 0.25 & 0.25 & -0.25 & 0.00 & 0.00 & 0.00 & 0.00 & 0.00 \\
\hline
\end{tabular}




\section{Wells College}

\begin{tabular}{|c|c|c|c|c|c|c|c|c|c|}
\hline Year & 2005 & 2006 & 2007 & 2008 & 2009 & 2010 & 2011 & 2012 & 2013 \\
\hline MRA Composite Index & & & 0.4 & 0.1 & -0.3 & 0.2 & 0.8 & 0.3 & 0.2 \\
\hline FRCS & & & 1.7 & 1.2 & 0.6 & 1.4 & 1.4 & \#N/A & \#N/A \\
\hline \multicolumn{10}{|l|}{ Index Components } \\
\hline Primary Reserve Ratio (25\%) & 0.75 & 0.75 & 0.57 & 0.04 & -0.25 & 0.00 & -0.15 & -0.25 & -0.25 \\
\hline Equity Ratio (12.5\%) & 0.38 & 0.38 & 0.38 & 0.38 & 0.38 & 0.38 & 0.38 & 0.38 & 0.38 \\
\hline Return on Net Assets Ratio (12.5\%) & -0.13 & -0.13 & -0.13 & -0.13 & -0.13 & -0.13 & 0.38 & -0.13 & 0.05 \\
\hline Net Operating Revenues Ratio (25\%) & -0.25 & -0.25 & -0.25 & -0.25 & -0.25 & 0.75 & 0.59 & -0.25 & 0.16 \\
\hline Risk Factors (25\%) & -0.25 & -0.25 & -0.25 & -0.25 & -0.25 & -0.25 & 0.00 & -0.25 & 0.00 \\
\hline MRA Index (Single Year) & 0.5 & 0.5 & 0.3 & -0.2 & $\begin{array}{ll}-0.5 \\
\end{array}$ & 0.7 & 1.2 & -0.5 & 0.3 \\
\hline \multicolumn{10}{|l|}{ Primary Reserve Ratio } \\
\hline Unrestricted Net Assets & $\$ 49,386,866$ & $\$ 48,290,870$ & $\$ 38,806,976$ & $\$ 30,118,962$ & $\$ 19,843,857$ & $\$ 22,086,718$ & $\$ 22,734,416$ & $\$ 17,609,846$ & $\$ 17,228,734$ \\
\hline Temporarily-restricted Net Assets & $\$ 11,521,791$ & $\$ 10,305,331$ & $\$ 2,161,812$ & $\$ 1,512,750$ & $\$ 1,033,578$ & $\$ 1,176,524$ & $\$ 2,419,868$ & $\$ 2,387,398$ & $\$ 3,029,378$ \\
\hline $\begin{array}{l}\text { Land, Building and Equipment, } \\
\text { net of depreciation }\end{array}$ & $\$ 32,020,791$ & $\$ 39,063,933$ & $\$ 33,247,122$ & $\$ 33,367,048$ & $\$ 28,931,077$ & $\$ 28,169,836$ & $\$ 28,622,642$ & $\$ 30,576,898$ & $\$ 29,712,017$ \\
\hline Long-term Debt & $\$ 1,892,024$ & $\$ 1,934,362$ & $\$ 2,559,097$ & $\$ 2,244,435$ & $\$ 5,031,747$ & $\$ 4,889,741$ & $\$ 1,615,160$ & $\$ 2,518,257$ & $\$ 3,814,494$ \\
\hline Total Expenses & $\$ 20,826,178$ & $\$ 22,309,750$ & $\$ 44,954,015$ & $\$ 31,426,210$ & $\$ 27,419,882$ & $\$ 28,414,452$ & $\$ 30,340,119$ & $\$ 30,043,570$ & $\$ 32,692,125$ \\
\hline Ratio & 1.48 & 0.96 & 0.23 & 0.02 & \begin{tabular}{l|l|}
-0.11 \\
\end{tabular} & \begin{tabular}{l|l}
0.00 \\
\end{tabular} & -0.06 & \begin{tabular}{l|l|}
-0.27 \\
\end{tabular} & -0.17 \\
\hline Strength Factor & 3.00 & 3.00 & 2.29 & 0.16 & -1.00 & -0.01 & -0.61 & -1.00 & -1.00 \\
\hline Weighted Value $(25 \%)$ & 0.75 & 0.75 & 0.57 & 0.04 & -0.25 & \begin{tabular}{ll|l}
0.00 \\
\end{tabular} & -0.15 & -0.25 & -0.25 \\
\hline
\end{tabular}

\begin{tabular}{|c|c|c|c|c|c|c|c|c|c|}
\hline \multicolumn{10}{|l|}{ Equity Ratio } \\
\hline Net Assets & $\$ 100,703,635$ & $\$ 98,597,533$ & $\$ 81,293,086$ & $\$ 73,740,629$ & $\$ 59,709,941$ & $\$ 57,946,564$ & $\$ 63,636,571$ & $\$ 58,958,296$ & $\$ 59,434,009$ \\
\hline Intangible Assets & $\$ 0$ & $\$ 0$ & $\$ 0$ & $\$ 0$ & $\$ 0$ & $\$ 0$ & $\$ 0$ & $\$ 0$ & $\$ 0$ \\
\hline Unsecured Related-party Receivables & $\$ 0$ & $\$ 0$ & $\$ 0$ & $\$ 0$ & $\$ 3,300,000$ & $\$ 3,300,000$ & $\$ 0$ & $\$ 0$ & $\$ 185,191$ \\
\hline Total Assets & $\$ 103,766,556$ & $\$ 103,477,343$ & $\$ 87,993,262$ & $\$ 77,656,175$ & $\$ 66,732,979$ & $\$ 64,522,103$ & $\$ 66,555,922$ & $\$ 62,749,812$ & $\$ 64,496,004$ \\
\hline - Intangible Assets & $\$ 0$ & $\$ 0$ & $\$ 0$ & $\$ 0$ & $\$ 0$ & $\$ 0$ & $\$ 0$ & $\$ 0$ & $\$ 0$ \\
\hline - Unsecured Related-party Receivables & $\$ 0$ & $\$ 0$ & $\$ 0$ & $\$ 0$ & $\$ 3,300,000$ & $\$ 3,300,000$ & $\$ 0$ & $\$ 0$ & $\$ 185,191$ \\
\hline Ratio & 0.97 & 0.95 & 0.92 & 0.95 & 0.89 & 0.89 & 0.96 & 0.94 & 0.92 \\
\hline Strength Factor & 3.00 & 3.00 & 3.00 & 3.00 & 3.00 & 3.00 & 3.00 & 3.00 & 3.00 \\
\hline Weighted Value (12.5\%) & 0.38 & \begin{tabular}{l|l|l}
0.38 & 0 \\
\end{tabular} & 0.38 & 0.38 & 0.38 & 0.38 & 0.38 & 0.38 & 0.38 \\
\hline \multicolumn{10}{|l|}{ Return on Net Assets Ratio } \\
\hline$\Delta$ Net Assets & $-\$ 4,199,070$ & $-\$ 2,106,102$ & $-\$ 17,304,447$ & $-\$ 7,552,457$ & $-\$ 14,030,688$ & $-\$ 1,763,377$ & $\$ 5,690,007$ & $-\$ 4,678,275$ & $\$ 475,713$ \\
\hline Total Net Assets (BOY) & $\$ 104,902,705$ & $\$ 100,703,635$ & $\$ 98,597,533$ & $\$ 81,293,086$ & $\$ 73,740,629$ & $\$ 59,709,941$ & $\$ 57,946,564$ & $\$ 63,636,571$ & $\$ 58,958,296$ \\
\hline Ratio & -0.04 & \begin{tabular}{|c|}
-0.02 \\
\end{tabular} & -0.18 & -0.09 & \begin{tabular}{|c|}
-0.19 \\
\end{tabular} & \begin{tabular}{|c|}
-0.03 \\
\end{tabular} & 0.10 & \begin{tabular}{|c|}
-0.07 \\
\end{tabular} & 0.01 \\
\hline Strength Factor & -1.00 & -1.00 & -1.00 & -1.00 & -1.00 & -1.00 & 3.00 & -1.00 & 0.40 \\
\hline Weighted Value (12.5\%) & -0.13 & \begin{tabular}{|c|}
-0.13 \\
\end{tabular} & -0.13 & -0.13 & -0.13 & -0.13 & 0.38 & -0.13 & 0.05 \\
\hline \multicolumn{10}{|l|}{ Net Operating Revenues Ratio } \\
\hline$\Delta$ Unrestricted Net Assets & $\$ 8,072,695$ & $-\$ 1,095,996$ & $-\$ 9,483,894$ & $-\$ 8,688,014$ & $-\$ 10,275,105$ & $\$ 2,242,861$ & $\$ 647,698$ & $-\$ 5,124,570$ & $-\$ 381,112$ \\
\hline Total Unrestricted Revenue & $-\$ 5,848,797$ & $\$ 11,270,534$ & $\$ 14,992,932$ & $\$ 18,734,901$ & $\$ 17,294,373$ & $\$ 19,153,587$ & $\$ 23,730,491$ & $\$ 22,314,452$ & $\$ 25,821,155$ \\
\hline Ratio & -1.38 & \begin{tabular}{l|l|l}
-0.10 \\
\end{tabular} & -0.63 & -0.46 & \begin{tabular}{ll|}
-0.59 \\
\end{tabular} & 0.12 & 0.03 & \begin{tabular}{l|l|}
-0.23 \\
\end{tabular} & -0.01 \\
\hline Strength Factor & -1.00 & -1.00 & -1.00 & -1.00 & -1.00 & 3.00 & 2.36 & -1.00 & 0.63 \\
\hline Weighted Value (25\%) & -0.25 & \begin{tabular}{|c|}
-0.25 \\
\end{tabular} & -0.25 & -0.25 & -0.25 & 0.75 & 0.59 & -0.25 & 0.16 \\
\hline \multicolumn{10}{|l|}{ Risk Factors } \\
\hline $\begin{array}{l}\text { Enrollment } \\
<1,000(2) \text { or }<2,500(1)\end{array}$ & 386 & 409 & 473 & 545 & 572 & 561 & 554 & 491 & 491 \\
\hline $\begin{array}{l}\text { Religious or Non-Degree Granting } \\
\text { yes }\end{array}$ & no & no & no & no & no & no & no & no & no \\
\hline $\begin{array}{l}\text { Ratio of Full-time to Part-time Students } \\
<3.0\end{array}$ & no $\mathrm{P} / \mathrm{T}$ & no $P / T$ & no $\mathrm{P} / \mathrm{T}$ & no $P / T$ & no $\mathrm{P} / \mathrm{T}$ & no $\mathrm{P} / \mathrm{T}$ & no $\mathrm{P} / \mathrm{T}$ & no $\mathrm{P} / \mathrm{T}$ & no $\mathrm{P} / \mathrm{T}$ \\
\hline $\begin{array}{l}\text { Tuition Discounting } \\
>60 \%\end{array}$ & $55 \%$ & $38 \%$ & $39 \%$ & $46 \%$ & $44 \%$ & $46 \%$ & $52 \%$ & $58 \%$ & $58 \%$ \\
\hline $\begin{array}{l}\text { Tuition Reliance } \\
>85 \%\end{array}$ & $51 \%$ & $41 \%$ & $54 \%$ & $41 \%$ & $61 \%$ & $59 \%$ & $47 \%$ & $62 \%$ & $62 \%$ \\
\hline $\begin{array}{l}\text { Interest Expense } \\
>10 \%\end{array}$ & $0 \%$ & $0 \%$ & $0 \%$ & $0 \%$ & $0 \%$ & $1 \%$ & $1 \%$ & $0 \%$ & $0 \%$ \\
\hline $\begin{array}{l}\text { Net Revenue } \\
<0\end{array}$ & $-\$ 4,219,760$ & $-\$ 1,061,435$ & $-\$ 22,006,321$ & $-\$ 1,701,614$ & $-\$ 7,715,526$ & $-\$ 3,531,827$ & $\$ 5,209,197$ & $-\$ 3,358,651$ & $-\$ 1,100,352$ \\
\hline $\begin{array}{l}\text { Endowment/Total Budget } \\
<3.0\end{array}$ & 0.39 & 0.39 & 0.94 & 0.91 & 0.98 & 1.00 & 1.33 & 1.28 & 0.00 \\
\hline Total Risk Factors & 4 & 4 & 4 & 4 & 4 & 4 & 3 & 4 & 3 \\
\hline Strength Factor & \begin{tabular}{l|}
-1 \\
\end{tabular} & \begin{tabular}{l|l}
-1 \\
\end{tabular} & -1 & $-1 \mid$ & \begin{tabular}{l|}
-1 \\
\end{tabular} & \begin{tabular}{l|}
-1 \\
\end{tabular} & 0 & \begin{tabular}{l|}
-1 \\
\end{tabular} & 0 \\
\hline Weighted Value (25\%) & -0.25 & \begin{tabular}{|c|}
-0.25 \\
\end{tabular} & -0.25 & -0.25 & -0.25 & -0.25 & 0.00 & -0.25 & 0.00 \\
\hline
\end{tabular}




\section{Wesleyan College}

\begin{tabular}{|c|c|c|c|c|c|c|c|c|c|}
\hline Year & 2005 & 2006 & 2007 & 2008 & 2009 & 2010 & 2011 & 2012 & 2013 \\
\hline MRA Composite Index & & & 2.2 & 2.2 & 1.4 & 0.6 & 1.2 & 0.8 & 1.6 \\
\hline FRCS & & & 3 & 3.0 & 0.6 & 0.8 & 2.9 & 1.2 & 2.7 \\
\hline \multicolumn{10}{|l|}{\begin{tabular}{|l|} 
Index Components \\
\end{tabular}} \\
\hline Primary Reserve Ratio (25\%) & 0.75 & 0.75 & 0.75 & 0.75 & -0.25 & -0.25 & 0.75 & 0.38 & 0.72 \\
\hline Equity Ratio (12.5\%) & 0.38 & 0.38 & 0.38 & 0.38 & 0.38 & 0.38 & 0.38 & 0.38 & 0.38 \\
\hline Return on Net Assets Ratio (12.5\%) & 0.38 & 0.24 & 0.38 & 0.37 & -0.13 & 0.23 & 0.38 & -0.13 & 0.31 \\
\hline Net Operating Revenues Ratio (25\%) & 0.75 & 0.75 & 0.75 & 0.75 & 0.75 & -0.05 & 0.75 & -0.25 & 0.75 \\
\hline Risk Factors (25\%) & 0.00 & 0.00 & 0.00 & 0.00 & -0.25 & -0.25 & 0.00 & -0.25 & 0.25 \\
\hline MRA Index (Single Year) & 2.3 & 2.1 & 2.3 & 2.2 & 0.5 & 0.1 & 2.3 & 0.1 & 2.4 \\
\hline \multicolumn{10}{|l|}{ Primary Reserve Ratio } \\
\hline Unrestricted Net Assets & $\$ 10,802,845$ & $\$ 11,356,396$ & $\$ 20,506,536$ & $\$ 23,064,133$ & $\$ 6,776,492$ & $\$ 6,034,938$ & $\$ 10,746,834$ & $\$ 4,723,150$ & $\$ 5,736,823$ \\
\hline Temporarily-restricted Net Assets & $\$ 15,655,131$ & $\$ 15,282,096$ & $\$ 8,307,500$ & $\$ 5,115,132$ & $\$ 3,510,354$ & $\$ 4,865,837$ & $\$ 8,338,236$ & $\$ 10,157,902$ & $\$ 11,314,235$ \\
\hline $\begin{array}{l}\text { - Land, Building and Equipment, } \\
\text { net of depreciation }\end{array}$ & $\$ 18,916,172$ & $\$ 18,085,670$ & $\$ 17,108,238$ & $\$ 28,068,052$ & $\$ 30,819,898$ & $\$ 29,159,748$ & $\$ 31,491,772$ & $\$ 30,208,917$ & $\$ 29,246,738$ \\
\hline Long-term Debt & $\$ 12,024,896$ & $\$ 11,642,736$ & $\$ 11,145,212$ & $\$ 11,154,603$ & $\$ 13,211,779$ & $\$ 12,795,035$ & $\$ 19,541,956$ & $\$ 18,503,395$ & $\$ 18,488,485$ \\
\hline Total Expenses & $\$ 16,863,629$ & $\$ 16,480,082$ & $\$ 17,591,889$ & $\$ 19,663,433$ & $\$ 21,611,410$ & $\$ 19,849,551$ & $\$ 20,383,100$ & $\$ 21,135,998$ & $\$ 21,877,661$ \\
\hline Ratio & 1.16 & 1.23 & 1.30 & 0.57 & \begin{tabular}{l|l|}
-0.34 \\
\end{tabular} & -0.28 & 0.35 & 0.15 & 0.29 \\
\hline Strength Factor & 3.00 & 3.00 & 3.00 & 3.00 & -1.00 & -1.00 & 3.00 & 1.50 & 2.88 \\
\hline Weighted Value (25\%) & 0.75 & 0.75 & 0.75 & 0.75 & -0.25 & -0.25 & 0.75 & 0.38 & 0.72 \\
\hline
\end{tabular}

\begin{tabular}{|c|c|c|c|c|c|c|c|c|c|}
\hline \multicolumn{10}{|l|}{ Equity Ratio } \\
\hline Net Assets & $\$ 69,279,573$ & $\$ 71,968,807$ & $\$ 78,128,839$ & $\$ 82,766,860$ & $\$ 68,771,377$ & $\$ 71,254,267$ & $\$ 81,280,782$ & $\$ 76,826,880$ & $\$ 80,609,975$ \\
\hline Intangible Assets & $\$ 0$ & $\$ 0$ & $\$ 0$ & $\$ 0$ & $\$ 0$ & $\$ 0$ & $\$ 0$ & $\$ 0$ & $\$ 0$ \\
\hline Unsecured Related-party Receivables & $\$ 0$ & $\$ 0$ & $\$ 0$ & $\$ 0$ & $\$ 0$ & $\$ 0$ & $\$ 0$ & $\$ 0$ & $\$ 0$ \\
\hline Total Assets & $\$ 82,844,568$ & $\$ 84,446,300$ & $\$ 91,071,194$ & $\$ 95,052,636$ & $\$ 82,959,255$ & $\$ 85,096,669$ & $\$ 102,090,359$ & $\$ 96,556,328$ & $\$ 100,797,801$ \\
\hline - Intangible Assets & $\$ 0$ & $\$ 0$ & $\$ 0$ & $\$ 0$ & $\$ 0$ & $\$ 0$ & $\$ 0$ & $\$ 0$ & $\$ 0$ \\
\hline - Unsecured Related-party Receivables & $\$ 0$ & $\$ 0$ & $\$ 0$ & $\$ 0$ & $\$ 0$ & $\$ 0$ & $\$ 0$ & $\$ 0$ & $\$ 0$ \\
\hline Ratio & 0.84 & 0.85 & 0.86 & 0.87 & 0.83 & 0.84 & 0.80 & 0.80 & 0.80 \\
\hline Strength Factor & 3.00 & 3.00 & 3.00 & 3.00 & 3.00 & 3.00 & 3.00 & 3.00 & 3.00 \\
\hline Weighted Value (12.5\%) & 0.38 & 0.38 & 0.38 & 0.38 & 0.38 & 0.38 & 0.38 & 0.38 & 0.38 \\
\hline \multicolumn{10}{|l|}{ Return on Net Assets Ratio } \\
\hline$\Delta$ Net Assets & $\$ 8,629,587$ & $\$ 2,689,234$ & $\$ 6,160,032$ & $\$ 4,638,021$ & $-\$ 13,995,483$ & $\$ 2,482,890$ & $\$ 10,026,515$ & $-\$ 4,453,902$ & $\$ 3,783,095$ \\
\hline Total Net Assets (BOY) & $\$ 60,649,986$ & $\$ 69,279,573$ & $\$ 71,968,807$ & $\$ 78,128,839$ & $\$ 82,766,860$ & $\$ 68,771,377$ & $\$ 71,254,267$ & $\$ 81,280,782$ & $\$ 76,826,880$ \\
\hline Ratio & 0.14 & 0.04 & 0.09 & 0.06 & -0.17 & 0.04 & 0.14 & -0.05 & 0.05 \\
\hline Strength Factor & 3.00 & 1.94 & 3.00 & 2.97 & -1.00 & 1.81 & 3.00 & -1.00 & 2.46 \\
\hline Weighted Value (12.5\%) & 0.38 & 0.24 & 0.38 & 0.37 & -0.13 & 0.23 & 0.38 & -0.13 & 0.31 \\
\hline \multicolumn{10}{|l|}{ Net Operating Revenues Ratio } \\
\hline$\Delta$ Unrestricted Net Assets & $\$ 4,273,941$ & $\$ 553,551$ & $\$ 9,150,140$ & $\$ 2,557,597$ & $-\$ 16,287,641$ & $-\$ 741,554$ & $\$ 4,711,896$ & $-\$ 6,023,684$ & $\$ 1,013,673$ \\
\hline Total Unrestricted Revenue & $\$ 8,979,734$ & $\$ 8,935,227$ & $\$ 9,452,996$ & $\$ 10,734,169$ & $-\$ 1,849,692$ & $\$ 15,676,837$ & $\$ 20,463,835$ & $\$ 9,818,327$ & $\$ 17,793,089$ \\
\hline Ratio & 0.48 & 0.06 & 0.97 & 0.24 & 8.81 & -0.05 & 0.23 & -0.61 & 0.06 \\
\hline Strength Factor & 3.00 & 3.00 & 3.00 & 3.00 & 3.00 & -0.18 & 3.00 & -1.00 & 3.00 \\
\hline Weighted Value (25\%) & 0.75 & 0.75 & 0.75 & 0.75 & 0.75 & -0.05 & 0.75 & -0.25 & 0.75 \\
\hline \multicolumn{10}{|l|}{ Risk Factors } \\
\hline $\begin{array}{l}\text { Enrollment } \\
<1,000(2) \text { or }<2,500(1)\end{array}$ & 555 & 513 & 491 & 521 & 542 & 512 & 525 & 505 & 505 \\
\hline $\begin{array}{l}\text { Religious or Non-Degree Granting } \\
\text { yes }\end{array}$ & no & no & no & no & no & no & no & no & no \\
\hline $\begin{array}{l}\text { Ratio of Full-time to Part-time Students } \\
<3.0\end{array}$ & 18.8 & 28.3 & 7.9 & 54.0 & 21.5 & no $\mathrm{P} / \mathrm{T}$ & 35.0 & 51.0 & no $\mathrm{P} / \mathrm{T}$ \\
\hline $\begin{array}{l}\text { Tuition Discounting } \\
>60 \%\end{array}$ & $42 \%$ & $41 \%$ & $43 \%$ & $48 \%$ & $49 \%$ & $53 \%$ & $47 \%$ & $46 \%$ & $46 \%$ \\
\hline $\begin{array}{l}\text { Tuition Reliance } \\
>85 \%\end{array}$ & $18 \%$ & $33 \%$ & $33 \%$ & $28 \%$ & $33 \%$ & $89 \%$ & $33 \%$ & $47 \%$ & $47 \%$ \\
\hline $\begin{array}{l}\text { Interest Expense } \\
>10 \%\end{array}$ & $3 \%$ & $3 \%$ & $3 \%$ & $2 \%$ & $0 \%$ & $3 \%$ & $3 \%$ & $4 \%$ & $3 \%$ \\
\hline $\begin{array}{l}\text { Net Revenue } \\
<0\end{array}$ & $\$ 9,148,287$ & $\$ 2,793,935$ & $\$ 3,731,117$ & $\$ 3,632,433$ & $-\$ 13,995,482$ & $\$ 2,482,888$ & $\$ 10,026,515$ & $-\$ 4,453,902$ & $\$ 3,783,095$ \\
\hline $\begin{array}{l}\text { Endowment/Total Budget } \\
<3.0\end{array}$ & 0.48 & 0.38 & 0.38 & 0.38 & 0.56 & 0.46 & 0.43 & 0.41 & 0.00 \\
\hline Total Risk Factors & 3 & 3 & 3 & 3 & 4 & 4 & 3 & 4 & 2 \\
\hline Strength Factor & 0 & 0 & 0 & 0 & -1 & -1 & 0 & -1 & 1 \\
\hline Weighted Value $(25 \%)$ & 0.00 & 0.00 & 0.00 & 0.00 & -0.25 & -0.25 & 0.00 & -0.25 & 0.25 \\
\hline
\end{tabular}

